\title{
20. BIOSTRATIGRAPHY AND BIOGEOGRAPHY OF TERTIARY BATHYAL BENTHIC FORAMINIFERS: TASMAN SEA, CORAL SEA, AND ON THE CHATHAM RISE (DEEP SEA DRILLING PROJECT, LEG 90) ${ }^{1}$
}

\author{
Anne Boersma ${ }^{2}$
}

\begin{abstract}
Eocene through Pliocene benthic foraminifers were examined from seven sites located at middle and lower bathyal depths on the Lord Howe Rise in the Tasman Sea, from another site at lower bathyal depths in the Coral Sea, and from a site in the intermediate-depth, hemipelagic province of the Chatham Rise, east of southern New Zealand. Age-related, depth-related, and bioprovincial faunal variations are documented in this chapter. One new species, Rectuvigerina tas mana, is named. The paleoecologic indications of several key groups, including the miliolids, uvigerinids, nuttallitids, and cibicidids, are combined with sedimentologic and stable isotopic tracers to interpret paleoceanographic changes in the Tasman Sea.

Because the total stratigraphic ranges of many bathyal benthic foraminifers are not yet known, most endpoints in the Tasman Sea are considered ecologically controlled events. The disappearances of Uvigerina rippensis and Cibicidoides parki and the first appearances of U. pigmaea, Sphaeroidina bulloides, and Rotaliatina sulcigera at the Eocene/Oligocene boundary can be considered evolutionary events, as also can the first appearance of Cibicides wuellerstorfi in Zone NN5.

Species which are restricted to the lower bathyal zone except during discrete pulses, most of which are related to the development of glacial conditions, include Melonis pompilioides, M. sphaeroides, Pullenia quinqueloba, Nuttallides umbonifera, and $U$. hispido-costata. Middle bathyal indigenes include $U$. spinulosa, U. gemmaeformis, Ehrenbergina marwicki, $R$. sulcigera, and all rectuvigerinids except Rectuvigerina spinea. Although the miliolids first occurred at lower bathyal depths, they were more common in the middle bathyal zone. Although the Neogene hispido-costate uvigerinids first developed at lower bathyal depths and at higher middle latitude sites, in the later Neogene this group migrated to shallower depths and became predominant also in the middle bathyal zone.

Despite the relatively similar sedimentologic settings at the six middle bathyal Tasman sites, there was extensive intrageneric and intraspecific geographic variation. Mililiolids, strongly ornamented brizalinids, bolivinitids, Bulimina aculeata, Osangularia culter, and strongly porous morphotypes were more common at higher latitudes. Osangularia bengalensis, striate brizalinids such as Brizalina subaenariensis, Gaudryina solida, osangularids in general, and finely porous morphotypes were more common in the subtropics. There was strong covariance between faunas at lower middle latitude, lower bathyal Site 591, and higher middle latitude, middle bathyal Site 593 .

The following oceanographic history of the Tasman Sea is proposed; using the stable isotopic record as evidence for glacials and examining the ecologic correlations between (1) miliolids and carbonate saturation, (2) nuttallitids and undersaturated, cooled, or "new" water masses, (3) uvigerinids with high organic carbon in the sediment and high rates of sediment accumulation, and (4) cibicidids and terrestrial organic carbon. The glacial located near the Eocene/Oligocene boundary is characterized by the penetration of cooler, more corrosive waters at intermediate depths in high southern latitudes. This may have caused overturn, upwelling pulses, in other Tasman areas. The development of Neogenelike conditions began in the late Oligocene (Zone NP24/NP25) with the evolution of several common Neogene species. A large number of Paleogene benthics disappeared gradually through the course of the early Miocene, which was not well preserved at any Tasman site. Corrosive conditions shallowed into the middle bathyal zone in several pulses during the early Miocene.

The development of glacial conditions in the middle Miocene was accompanied by major changes throughout the Tasman Sea. Sediment accumulation rates increased and high-productivity faunas and corrosive conditions developed at all but the lowest-latitude Site 588. This increase in productivity and accumulation rate is attributed to the eutrophication of Antarctic water masses feeding Tasman current systems, as well as to invigorated circulation in general. It overlaps with the beginning of the Pacific High-productivity Episode (10-5 Ma). During the latest Miocene glacial episode, corrosive conditions developed at lower bathyal depths, while cooler water and lower nutrient levels shallowed to middle bathyal depths. Lower input of terrestrial organic carbon may be related to the lower nutrient levels of this time and to the termination of the Pacific High-productivity Episode.

The moderate glacial episode during the mid-Pliocene (Zone NN15/NN16, $\sim 3.2 \mathrm{Ma}$ ) corresponds to a decline in sediment accumulation rates and a reorganization of faunas unlike that of all other times. New genera proliferate and indices for cool, noncorrosive conditions and high organic carbon expand throughout the middle bathyal zone coeval with the sedimentation rate decreases. By the latest Pliocene (about $2.5 \mathrm{Ma}$ ), however, during another glacial episode, faunal patterns typical of this and later glacials develop throughout the Tasman Sea. Benthic foraminiferal patterns suggest increased input of terrestrial organic matter to Tasman Sea sediments during this episode and during later glacials.
\end{abstract}

\section{INTRODUCTION}

During DSDP Leg 90, seven sites were drilled along the Lord Howe Rise, the medial ridge of the Tasman

\footnotetext{
${ }^{1}$ Kennett, J. P., von der Borch, C. C., et al., Init, Repts. DSDP, 90: Washington (U.S.
} Govt, Printing Office).

2 Address: Microclimates, P.O. Box 404, RR1, Stony Point, NY 10980.
Sea. These sites occupied a latitudinal range of from near $21^{\circ} \mathrm{S}$ to over $40^{\circ} \mathrm{S}$, and all but one were drilled at depths of between 1000 and $2000 \mathrm{~m}$ (Table 1). An additional high-latitude site, Site 594, was drilled on the Chatham Rise, in the hemipelagic province to the southeast of New Zealand. In order to construct a latitudinal traverse extending to the equator, Site 586, drilled on Leg 89 in 2,207 $\mathrm{m}$ water depth on the Ontong-Java Plateau (Fig. 1), was made available for this study. 
Table 1. Location and drilling data for Leg 90 sites.

\begin{tabular}{cccc}
\hline & $\begin{array}{c}\text { Water } \\
\text { depth } \\
(\mathrm{m})\end{array}$ & $\begin{array}{c}\text { Latitude } \\
(\mathrm{S})\end{array}$ & $\begin{array}{c}\text { Longitude } \\
(\mathrm{E})\end{array}$ \\
\hline 586 & 2207 & $0^{\circ} 29$ & $158^{\circ} 29$ \\
587 & 1101 & $21^{\circ} 11$ & $161^{\circ} 19$ \\
588 & 1533 & $26^{\circ} 06$ & $161^{\circ} 13$ \\
589 & 1391 & $30^{\circ} 42$ & $163^{\circ} 38$ \\
590 & 1299 & $31^{\circ} 10$ & $163^{\circ} 21$ \\
591 & 2131 & $31^{\circ} 35$ & $164^{\circ} 26$ \\
592 & 1098 & $36^{\circ} 28$ & $165^{\circ} 26$ \\
593 & 1068 & $40^{\circ} 30$ & $167^{\circ} 40$ \\
594 & 1204 & $45^{\circ} 31$ & $174^{\circ} 56$ \\
\hline
\end{tabular}

Cenozoic sediments were recovered from all sites; the only Paleogene samples were cored at Sites 588, 592, and 593. Faunas of the late Eocene through the late Pliocene only are described here.

This chapter documents, with extensive faunal lists, scanning electron microscopy, and detailed species descriptions the large and unique intermediate-depth benthic foraminiferal faunas of the Tasman Sea. In addition, faunal and specific variability through depth and latitude have been analyzed during the following climatic and sedimentologic events: (1) the Eocene/Oligocene boundary; (2) the mid-Miocene glacial; (3) the late Miocene carbon isotope excursion; and (4) the late Miocene through early Pliocene sedimentation increase.

\section{METHODS}

Between 15 and 35 samples from each series (lower, middle, or upper) were processed on $>149 \mu \mathrm{m}$ sieve. An aliquot of $0.5 \mathrm{mg}$ was split out of the washed fraction, and all benthic foraminifers were picked from that $0.5 \mathrm{mg}$. All species in faunas consisting of several hundred individuals are listed for each series recovered at each site.

Biostratigraphic subdivision of each site and intersite correlations follow the schemes of Jenkins and Srinivasan (this volume). Sedimentation rates were calculated on the basis of the nannofossil biostratigraphy (see site chapters, this volume).

\section{TAXONOMY}

For this report I have made an extensive search of the older literature and of topotypic faunas described in that literature in order to update some of the benthic foraminiferal taxonomy. For the most part benthic foraminifers described in Deep Sea Drilling volumes are still reported according to the taxonomy developed largely in the western hemisphere by Cushman, Bermudez, Beckmann, Renz, and others. Tertiary-age middle to lower bathyal benthic foraminifers were, however, cosmopolitan and ranged into areas as far removed as the Vienna Basin, the Cape Basin, and the type Bortonian of New Zealand. Benthic foraminiferal faunas of the eastern hemisphere were, for the most part, described much earlier (for example, d'Orbigny, 1846; Reuss, 1851; Schwager, 1866 ) and many of those names should take precedence.

Many of the synonyms found in the literature on bathyal benthics reflect the process of geographic variation which has, throughout the Tertiary, produced specific morphotypes in each biogeographic province of the world ocean. Thus, the lower bathyal hispido-costate uvigerinid of the Caribbean province in the early Oligocene is called Uvigerina spinicostata Cushman and Bermudez; the austral variant is named $U$. bortotara Finlay. The two taxa reflect the fact that more costae are consistently developed on this form in the southwest Pacific than in the Caribbean.

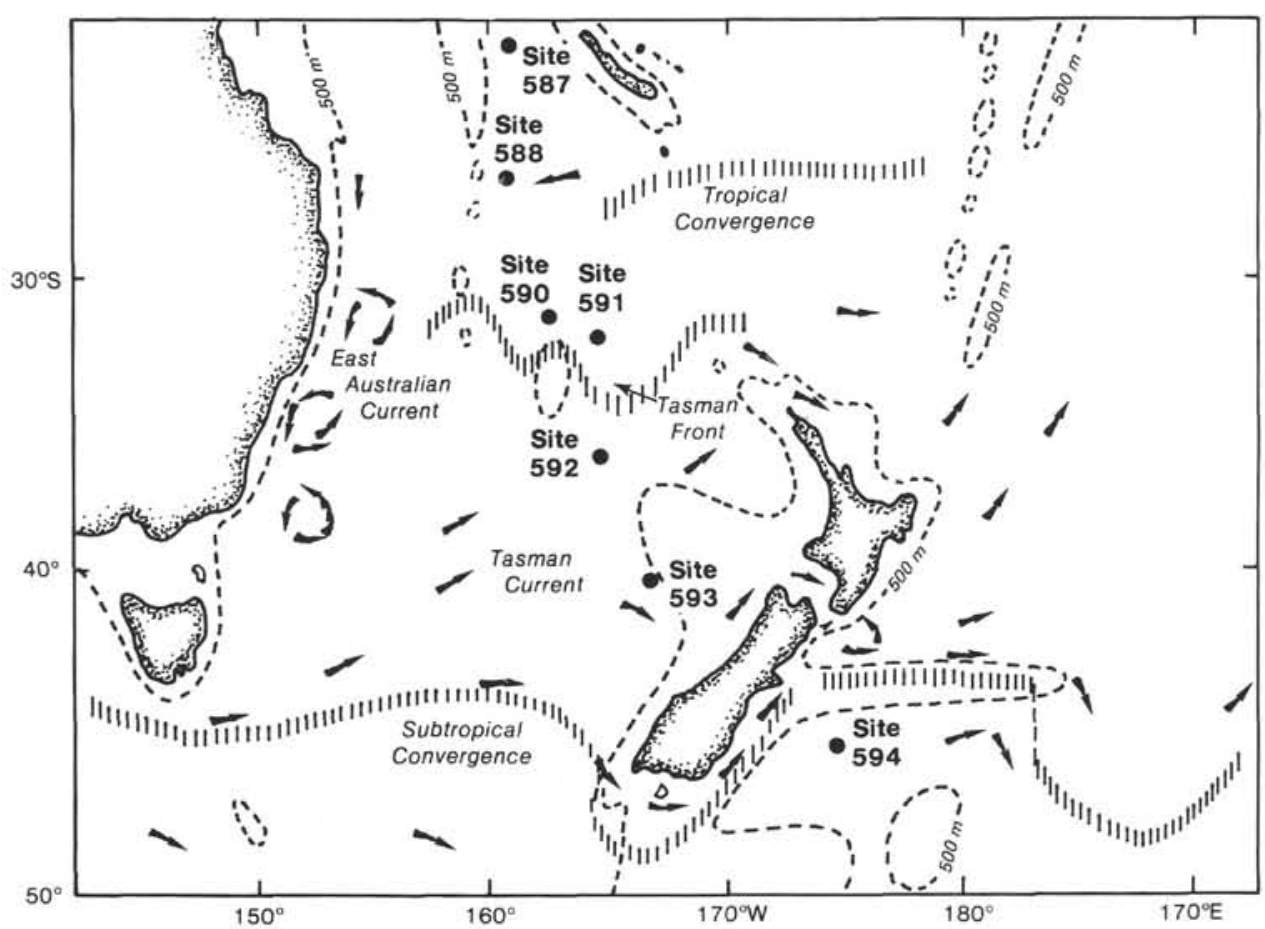

Figure 1. Location map of Leg 90 sites in the Tasman Sea, Coral Sea, and on the Chatham Rise. 
The correct procedure for distinguishing this type of ecophenotypic variation is to erect forma for the younger, distinguishable variants. Because this taxonomy is so ponderous and because many variants do have determinable features which differentiate them, I have, for the most part, retained the geographically defined names in this report.

\section{SITE DESCRIPTIONS}

For each site the following aspects of the faunas will be briefly described: (1) general faunal aspects; (2) most consistently appearing species; (3) species unique to the site; (4) dominant species; (5) other fossils; and (6) the total number of species.

\section{Hole 586B}

Sediments of latest Miocene (Zone N17a) through latest Pliocene (Zone N21) age were recovered in this hole, which was drilled at $2,207 \mathrm{~m}$ water depth on the Ontong-Java Plateau near DSDP Site 289. Preservation of benthic foraminifers is only fair to moderate through most of this interval; it improves during the latest Pliocene Zone N21, when it is generally good.

The 63 species of benthic foraminifers identified in the late Miocene at this site are listed in Appendix Table 1. Highly dominant species are Uvigerina proboscidea Schwager, Uvigerina hispido-costata Cushman and Todd, and Uvigerina auberiana d'Orbigny-this species last primarily at the very end of the Miocene, in sediments which also contain moderate amounts of radiolarians in the coarse fractions. The most consistently occurring species include Oridorsalis umbonatus (Reuss), Cibicides wuellerstorfi (Schwager), Globocassidulina subglobosa (Brady), and diverse miliolids. Unique elements in these faunas include Melonis sphaeroides (Voloshnaya), the genus Bulava, named by Boltovskoy (1978) from the Ninetyeast Ridge in the Indian Ocean, a new uvigerinid named Uvigerina tasmana (Boersma, 1984a), and specimens of Brizalina aenariensis (Costa). Species which occur consistently at this site, as well as at the other 2,000-m-deep Site 591, include Melonis pompilioides (Fichtel and Moll), Pullenia quinqueloba (Reuss), and the spiroplectaminidform of Vulvulina pennatula Batsch. Other similarities between these two deeper-water sites include: (1) consistent appearance of U. hispido-costata; (2) absence of most species of rectuvigerinids, Hopkinsina mioindex Finlay, or Osangularia culter (Parker and Jones); and (3) the occasional presence of Favocassidulina favus (Brady).

From Pliocene sediments a total of 63 benthic foraminiferal species were identified (Appendix Table 2). Above the Miocene/Pliocene boundary, $U$. auberiana, the only highly dominant species in this section, occurs during Zones N19-N20, equivalent to nannofossil Zone NN15. Other consistent elements of these faunas include C. wuellerstorfi and diverse miliolids. Nuttallides umbonifera (Cushman) occurs more consistently here than at any other site; it is absent, however, during the uvigerinid maxima in Zones N19-N20. Species occurring frequently, but not consistently, include Pyrgo murrhina Schwager, $U$. hispido-costata, Pullenia bulloides (d'Or- bigny), G. subglobosa, and Oridorsalis umbonatus. Species of Osangularia, Ehrenbergina, and Heterolepa are much less common here than at other sites.

\section{Site $\mathbf{5 8 7}$}

The 13 cores of late Miocene to Quaternary age recovered at Site 587 contained mixed benthic foraminiferal faunas: mixed into an apparently typical intermediate-depth benthic fauna composed of such species as Textularia lythostrota (Schwager), Brizalina aenariensis, and Globocassidulina subglobosa, there were calcareous algae, pteropods, mollusk shells, and shallow-water benthic foraminifers of the genera Tretomphalus, Amphistegina, Spiropthalmidium, Miliolinella, and Elphidium. From Core 10 to Core 13 (late Miocene), sediments consisted of recrystallizing carbonate sands with rare, larger, benthic foraminifers.

Core 7, of latest Miocene age, contained floods of bolivinids, uvigerinids, and rectuvigerinids, among which there is a new species characterized by very abundant, fine, and wavey striations, most of which are continuous from one chamber to the next; this species, Rectuvigerina tasmana, is described in the Annotated List of Species at the end of this chapter.

\section{Site $\mathbf{5 8 8}$}

The section recovered at Site 588 extends from upper Oligocene Zone P21a, called the Chiloguembelina cubensis Zone in this area, through the upper Pliocene. The lower part of the section, from the Oligocene through the lower Miocene into the Globorotalia fohsi Zone, is poorly preserved, benthics are very rare to infrequent, the sediment is recrystallized, and much of the coarse fraction is missing. Poor preservation continues from Cores 588C-19 through 588C-1, and into Core 588B-31; preservation improves, however, and faunas become very diverse in Cores 588B-27 through 588B-25.

\section{Oligocene}

Late Oligocene faunas are found in Cores $588 \mathrm{C}-19$ through $588 \mathrm{C}-9$ in recrystallized sediments containing radiolarians, glauconite, and frequently, iron oxides. Most faunas include the solution-resistant forms Cibicidoides tuxpamensis (Cole), Pullenia bulloides, Globocassidulina subglobosa, Oridorsalis umbonatus, Heterolepa kullenbergi (Parker), Bulimina semicostata Nuttall, Vulvulina spinosa Cushman, and Gyroidinoides spp. (Appendix Table 3).

Despite dissolution, many modern forms appear in the faunas beginning in the latest Oligocene Globigerina angulisuturalis Zone (Sample 588-16,CC). These species include Osangularia bengalensis (Schwager), H. kullenbergi, Textularia lythostrata, $P$. quinqueloba, Uvigerina pigmaea d'Orbigny, Bulimina striata d'Orbigny, Stilostomella lepidula (Schwager) and Melonis barleeanum (Williamson).

\section{Early to middle Miocene}

Sediments of early to middle Miocene age are found in Cores $588 \mathrm{C}-8$ to $588 \mathrm{C}-1$ and $588 \mathrm{~B}-31$ to $588 \mathrm{~B}-25$. Sediments are more chalky than those underlying. Faunas 
are slightly larger; a total of 75 species was recognized. The only highly dominant species is Eggerella bradyi (Cushman). The most consistently occurring species are Globocassidulina subglobosa, O. umbonatus, Anomalinoides semicribrata, the rectuvigerinids, and Heterolepa kullenbergi. Nuttallides umbonifera first appears at the base of the section and occurs through the lower Miocene in small numbers (Appendix Table 3).

Uvigerinids found at this site include very spinose forms such as Uvigerina proboscidea Schwager and the two species related to Uvigerina spinulosa Hadley, Rectuvigerina ongleyi Finlay and Rectuvigerina spinea (Bermudez).

Within the Globorotalia fohsi Zone, preservation improves and the number of benthic foraminifers increases dramatically. Heterolepa rugosa (Phleger and Parker) and Cibicides wuellerstorfi (Schwager) first occur in this zone.

\section{Middle through late Miocene}

Sixty-nine species were identified in middle to upper Miocene sediments in which microfossil preservation was good to moderate $(588-25, \mathrm{CC}$ to $588-13-2,19 \mathrm{~cm}$; Appendix Table 4). Preservation was consistently good through the Neogloboquadrina continuosa Zone (Cores 22 through 20).

Highly dominant species occurred only during the late Miocene: Textularia lythostrota during the Globorotalia plesiotumida Zone and the miliolids in several samples from Cores 13 and 14 at the top of the G. margaritae Zone (equivalent to nannofossil Zone NN11b). Species consistently present include Oridorsalis umbonatus, Sphaeroidina bulloides, T. lythostrata, Stilostomella consobrina d'Orbigny, Eggerella bradyi, Heterolepa kullenbergi, and Gaudryina solida Schwager. Whereas Melonis $\mathrm{cf}$. barleeanum occurred consistently only before the Globorotalia plesiotumida Zone, Osangularia bengalensis and Uvigerina hispida Schwager were consistently present only during the Globorotalia plesiotumida Zone and later.

During a latest Miocene episode of miliolid abundance, faunas were characterized by a decrease in Globocassidulina subglobosa and Oridorsalis umbonatus, and the consistent occurrence of $U$. hispida, Bulimina truncana, H. kullenbergi, and Gaudryina solida.

\section{Pliocene}

Pliocene sediments at this site are moderately well preserved and contained 77 species of benthic foraminifers, 37 of which were rectilinear (Appendix Table 5). The dominant species were, in the early Pliocene, Gaudryina solida; Cibicides wuellerstorfi and Bolivinopsis praelon$g a$ Schwager in the mid-Pliocene Globorotalia puncticulata Zone; and at the very end of the Pliocene B. praelonga (Sample 588-4,CC). Species appearing consistently through this section include Globocassidulina subglobosa, C. wuellerstorfi, Osangularia bengalensis, Bulimina truncana, and Eggerella bradyi. Uvigerina proboscidea, Stilostomella lepidula Schwager, and $H$. kullenbergi are also common. The miliolids and $G$. solida are common only during the early part of the Pliocene, whereas $C$. wuellerstorfi, $S$. lepidula, and $U$. proboscidea are more common in the Globorotalia crassaformis Zone and later.

A large variety of uvigerinids is present in these samples. The hispid types and the small hispido-costate $U$. pigmaea occur with the large costate form U. gemmaeformis and the new striate species, $U$. tasmana (Boersma, 1984a). Although $U$. spinulosa and Rectuvigerina spinea range into the Globorotalia tosaensis Zone, only the hispido-costate species $U$. hispido-costata and $U$. dirupta occur in the latest Pliocene. Both are strongly spinose in this area.

\section{Site 589}

Only four cores of Quaternary age were recovered before this site was abandoned. Sediment preservation is good and benthic foraminifers are abundant. In two cores volcanic glass constitutes almost $50 \%$ of the sediment. Typical species through this section are Cassidulina laevigata carinata Cushman, Uvigerina dirupta, Heterolepa kullenbergi, Cibicides wuellerstorfi, Oridorsalis umbonatus, U. auberiana, Globocassidulina subglobosa, and Stilostomella lepidula.

\section{Site $\mathbf{5 9 0}$}

A uniform sequence of carbonate oozes was recovered at Site 590, in both Holes 590A and 590B. The lower to middle Miocene section is poorly preserved except for Cores 44 to 46 , in which preservation is moderate. Middle to upper Miocene sediments (590B-28 to $590 \mathrm{~B}-40, \mathrm{CC}$ and $590 \mathrm{~A}-18$ to $590 \mathrm{~A}-27, \mathrm{CC}$ ) are fairly to moderately well preserved; good preservation was found only in Sample 590A-26,CC. Preservation improves in the Pliocene, where it is moderate to good from 590A$17, \mathrm{CC}$ to $590 \mathrm{~A}-7, \mathrm{CC}$, and good in Cores 6 through 14. Radiolarians occur in sediments of the coarse fractions only during the Neogloboquadrina continuosa and basal Globigerina nepenthes zones of the upper Miocene and in core 590B-47 during the middle Miocene Globorotalia fohsi Zone.

\section{Early to middle Miocene}

Sediments of early Miocene age were recovered in Cores 590B-53 through 590B-49. The preservation of these levels is extremely poor because of dissolution and recrystallization. Only the dissolution-resistant species, Globocassidulina subglobosa, Heterolepa kullenbergi, $H$. rugosa, Oridorsalis umbonatus, Brizalina pusilla (Schwager), and Gyroidinoides spp. were preserved in most levels (Appendix Table 6).

Beginning in the middle Miocene Globorotalia fohsi Zone (equivalent to Zone NN6) in Core 590B-46, faunas become slightly more diverse and usually contain Hopkinsina mioindex along with the solution-resistant forms. Faunas of the $G$. mayeri Zone are moderately well preserved and more diverse. Consistent elements during this interval include Eggerella bradyi along with the solution-resistant group of the early Miocene. Occasionally present are Melonis barleeanum, Pullenia bulloides, and Uvigerina spinulosa (Appendix Table 6). 


\section{Middle to late Miocene}

Sediments of middle to late Miocene age are fairly well to moderately well preserved; preservation improves in general toward the end of this interval. Eighty-four benthic species were recognized and are listed in Appendix Table 7.

The Neogloboquadrina continuosa and earliest Globigerina nepenthes zones are present in Cores 590B-28 through 590B-40. Radiolarians occur throughout these cores. Highly dominant species include Heterolepa kullenbergi, Eggerella bradyi, and Rectuvigerina spinea, which was consistent and highly dominant in the later part of the $N$. continuosa Zone and earlier $G$. nepenthes Zone. Other consistently occurring species include Oridorsalis umbonatus throughout this time; Uvigerina proboscidea, Hopkinsina mioindex, and Brizalina pusilla occur consistently only from the $G$. nepenthes Zone to the end of the Miocene.

A large faunal shift takes place midway in the $N$. continuosa Zone (Cores 590B-34 to 590B-33). Accompanying an improvement in the preservation and a change in dominance from $H$. kullenbergi to $R$. spinea are large numbers of brizalinids and Melonis pompilioides. Radiolarians become much less common above this level.

The late Miocene G. nepenthes and Globorotalia conomiozea zones are represented from Section 590A-28-5 through 590A-18,CC (Appendix Table 7). Faunas in this interval are generally better preserved and more diverse than those below. Benthic foraminifers become very abundant in one well-preserved fauna (590A-26,CC) which lacks coarse-fraction radiolarians and is dominated by $R$. spinea. Uvigerinids, brizalinids, and cibicidids are the most common forms and Nuttallides umbonifera, Osangularia bengalensis, and $U$. auberiana all first occur during this time. The miliolids occur only during the latest Miocene $G$. conomiozea Zone, which is also characterized by the consistent presence of Bulimina truncana, Stilostomella lepidula, Oridorsalis umbonatus, $H$. kullenbergi, and Globocassidulina subglobosa, which is not common before this time.

Throughout the late Miocene, Osangularia bengalensis is more common than $O$. culter. The spinose uvigerinids and the spinose rectuvigerinids predominate, although $U$. gemmaeformis, a large, striate species, does occur in some samples. Uvigerina hispido-costata first occurs near the end of the Miocene. Species of Laticarinina, Alabamina, and Anomalinoides are not common, and both $C$. wuellerstorfi and $G$. subglobosa are noteworthy by their absence from many samples.

\section{Pliocene}

Eighty-three benthic foraminiferal species were identified from Pliocene sediments in Core 590A-17 through Sample 590A-4-4, $19 \mathrm{~cm}$ (Appendix Table 8). Preservation varies from moderate to good; the good preservation is typical of the beginning and the end of this interval. Highly dominant species include Uvigerina proboscidea, $U$. hispida, and Uvigerina striata d'Orbigny in the Globorotalia crassaformis Zone and U. proboscidea, $U$. auberiana, U. striata, U. hispido-costata, and Uviger- ina asperula Czjeck during the Globorotalia inflata Zone. The uvigerinids occurred less consistently than Heterolepa kullenbergi, T. lythostrota, S. lepidula, or G. subglobosa.

In the late Pliocene, before Zone NN19-NN20, rectilinear genera such as Stilostomella, Ehrenbergina, and Uvigerina are most common, whereas cibicidids are rare; the pattern reverses in Zone NN19-NN20.

\section{Site 591}

A section ranging in age from early Miocene through late Pliocene was recovered from Holes 591 and 591B. As at several other sites, the preservation in the early Miocene is poor, improves to fair to moderate in the late Miocene, and is generally moderate throughout the Pliocene. Radiolarians occur in the coarse fractions only during the Globorotalia mayeri Zone (Core 591B-11) and in the later Miocene G. conomiozea Zone (Cores 591-22 and 591-21).

\section{Early to middle Miocene}

Early to middle Miocene faunas were found in Cores 591B-24 to 591B-8 (Appendix Table 9). From Cores 24 through 20, sediments are recrystallized and most of the foraminifers are broken. Solution-resistant species in this type of sediment are Oridorsalis umbonatus and Eggerella bradyi. Faunas become more diverse beginning in Core 18, but even in the late Miocene faunas are smaller than those at other sites and sediments are generally less well preserved.

In this section where species abundances may be largely the result of the dissolution process, dominant species include Globocassidulina subglobosa and Nuttalides umbonifera. The most consistently occurring species are $O$. umbonatus, E. bradyi, Cibicides wuellerstorfi, G. subglobosa, and Heterolepa kullenbergi.

Twelve species first occur in the Tasman Sea at Site 591 during the early middle Miocene (see section on biostratigraphy). Nuttallides umbonifera first appears at this site during the Orbulina suturalis Zone (equivalent to nannofossil Zone NN5). It recurs, along with frequent $C$. wuellerstorfi, during the mid Globorotalia fohsi Zone (591B-15,CC). During the G. mayeri Zone in Cores 591B-12 and 591B-11 (equivalent to nannofossil Zone NN7 and NN8), Pullenia bulloides and N. umbonifera both become dominant faunal elements, and N. umbonifera is very large. Faunas containing large-sized, abundant $N$. umbonifera occur at Site 594 at this same time.

\section{Late Miocene}

In the fairly to moderately well preserved late Miocene faunas $(591-31, C C$ to $591-20-4,19 \mathrm{~cm}) 65$ species of benthic foraminifers were recognized (Appendix Table 10). Beginning in the Globigerina nepenthes Zone, the dominant species are Uvigerina hispido-costata, Pyrgo comata (Schwager), and other diverse miliolids. The most consistently occurring species besides $U$. hispidocostata are Bulimina truncana, Heterolepa kullenbergi, Oridorsalis umbonatus and, to a lesser degree, Sigmoilopsis schlumbergeri (Silvestri) and Pyrgo spp. Globocassidulina subglobosa is usually rare. 
Faunas in Cores 591-21 to 591-27 (Neogloboquadrina continuosa into Globorotalia conomiozea zones) contain very abundant miliolid fragments. Typically there are few species, but many specimens of each. The residue fauna found in very dissolved sediments in Core 21 is different from those of the earlier Miocene at this site; it includes $P$. murrhina, O. umbonatus, Nuttalides umbonifera, Quinqueloculina seminulina Linne, Cibicidoides cicatricosus (Schwager), Ehrenbergina spp., and $G y$ roidinoides spp.

Near the end of the sequence faunas are more diverse, contain few agglutinated species, rare Globocassidulina subglobosa, and very few anomalinids. Uvigerina hispido-costata has been replaced by $U$. hispida and several different species such as Laticarinina halophora (Stache) and Brizalina finlayi (Hornibrook) reappear.

\section{Pliocene}

The 66 species of benthic foraminifers that are identified through this section are listed in Appendix Table 11. Twenty-six of these species are rectilinear and approximately six are agglutinated. Species which become strongly dominant include Pyrgo spp. and Bulimina truncana, and the most consistently occurring forms along with B. truncana are Stilostomella consobrina, Globocassidulina subglobosa, Oridorsalis umbonatus, and $\mathrm{Ci}$ bicidoides bradyi (Trauth). Cibicidids become frequent at the end of the Pliocene.

Osangularia bengalensis, but not $O$. culter, occurs at this site. Uvigerinids are primarily hispido-costate with the addition of the spinose $U$. proboscidea. Hopkinsina mioindex recurs during the middle Globorotalia crassaformis Zone and occurs consistently into the mid $G$. tosaensis Zone.

\section{Site $\mathbf{5 9 2}$}

The section at this site extends from the upper Eocene Globigerina aculeata Zone through the upper Pliocene. However, the entire upper Oligocene and the first zone of the Miocene are missing. Sediments of the upper Eocene and lower Miocene are fairly well preserved, those of the upper Miocene moderately well preserved, and preservation throughout the Pliocene is good. Few radiolarians were found in the coarse fractions.

\section{Paleogene}

Seventy-five species were identified from sediments of late Eocene through early Oligocene age at this site. Preservation in the upper Eocene sediments was fair to moderate; it improved in the lower Oligocene (Appendix Table 12). Highly dominant species in this section include Cibicidoides parki (Finlay), Uvigerina bortotara Finlay, Anomalinoides aragonensis (Nuttall), and Oridorsalis umbonatus. There are many species which occur very consistently throughout this sequence; they include Globocassidulina subglobosa, U. bortotara, Hanzawaia cushmani, C. parki, O. umbonatus, Cibicidoides grimsdalei Cole, Anomalinoides alazanensis (Nuttall), Anomalinoides semiteres Finlay, Cibicidoides cf. ungerianus d'Orbigny, and Heterolepa trans. kullenbergi.
The Eocene/Oligocene boundary is located between Sample 592-36-2, $19 \mathrm{~cm}$ and 592-35,CC. Radiolarians appear just within this interval, but disappear immediately afterwards. Species which disappear at this time include C. parki, Uvigerina rippensis Cole, Rotaliatina sulcigera Finlay, and Cibicidoides tuxpamensis Nuttall. Just above the boundary Pullenia bulloides, $U$. bortotara, and $U$. cf. pigmaea also disappear. In the earliest Oligocene two species of Laticarinina, L. halophora and L. altocamerata Chapman and Parr, first appear. Oridorsalis umbonatus becomes the dominant species for the first time.

Several modern species which appear for the first time in the Globigerina angiporoides Zone (592-34-2, $19 \mathrm{~cm})$ include Pullenia quinqueloba, Hopkinsina mioindex, and Eggerella bradyi.

\section{Early to middle Miocene}

In the early to middle Miocene sequence (592-32,CC to $529-24-6,19 \mathrm{~cm}$ ) 67 species were recognized (Appendix Table 13). In sediments where preservation is only fair, the only highly dominant species is Cassidulina laevigata carinata. The consistently appearing species are Heterolepa kullenbergi, Globocassidulina subglobosa, Brizalina reticulata (Hantken), and Oridorsalis umbonatus. Frequently present are Laticarinina bullbrooki and Cibicides trans. wuellerstorfi.

A major origination episode takes place during the Globorotalia mayeri Zone (equivalent to nannofossil Zone NN6) in Core 26, producing 12 new species. Among these are Pleurostomella alternans Schwager, Cibicides lobatulus (Walker and Jacob), Anomalinoides globulosa Chapman and Parr, Cibicidoides trans. cicatricosus, Stilostomella subspinosa, and Siphotextularia solita Schwager. Hopkinsina mioindex reappears at this time and Marginulinopsis mammilligera (Karrer) becomes extinct. Nuttallides umbonifera becomes more abundant during this same interval.

\section{Late Miocene}

Sediments of late Miocene age (592-23-2, $19 \mathrm{~cm}$ to $592-12$, CC) are fairly to moderately well preserved. Radiolarians occur only in the coarse fraction of Sample $592-21-3,19 \mathrm{~cm}$. Although benthic foraminifers are not common, 79 species were identified and are listed in Appendix Table 14.

In this section the highly dominant and consistent species are very different in the early part (that part of the G. miotumida Zone prior to nannofossil Zone NN11a in Core 18) and the late $G$. miotumida Zone through the G. conomiozea Zone (Cores 18 to 12). Dominant species of the early part are Hopkinsina mioindex and Rectuvigerina spinea; in the later part, Uvigerina hispida predominates. Although $H$. mioindex, Oridorsalis umbonatus, Heterolepa kullenbergi, and Brizalina pusilla are consistent throughout the section, only during the early part are R. spinea, Laticarinina halophora, and Globocassidulina subglobosa consistently present. In the later part, consistent species are Cibicides lobatulus, Heterolepa rugosa, Textularia lythostrota, Cibicidoides cf. un- 
gerianus, and Pullenia bulloides. Several new species of miliolids and uvigerinids first occur during this interval and agglutinated forms are more common. Cibicides wuellerstorfi becomes rare, however. At the very end of the section both $U$. hispido-costata and the miliolids increase in import.

\section{Pliocene}

Seventy-eight species were recognized (Appendix Table 15) in this sequence, which is well preserved throughout. No one species becomes highly dominant, but there are many species which occur consistently: Brizalina pusilla, Sphaeroidina bulloides, Sigmoilopsis schlumbergeri, Globocassidulina subglobosa, Oridorsalis umbonatus, Stilostomella lepidula, and Melonis barleeanum.

There is one marked faunal change during the midPliocene at the Globorotalia crassaformis/G. inflata zonal boundary (equivalent to the NN15/NN16 boundary). Several uvigerinids, miliolids, and anomalinids, Bulimina truncana, and Melonis affinis (Reuss) all disappear at this time. Osangularia culter enters the area for the first time and species of Pyrgo increase in import. Overlying faunas contain similar genera, but different species of those genera. For example, B. striata replaces B. truncana, Uvigerina proboscidea replaces $U$. hispida, and Cibicidoides cicatricosus replaces $C$. cf. ungerianus.

\section{Site 593}

A section ranging from latest Eocene (Globigerina linaperta Zone) through the Pliocene was recovered at this site. The Eocene and Oligocene sediments are moderately well preserved. Only moderately preserved at its beginning, the Miocene is well preserved in the middle part, but only moderately well preserved at its end. The Pliocene is well preserved throughout.

\section{Paleogene}

Paleogene sediments were found in Cores 593-60 to 593-49; the Eocene/Oligocene boundary is placed between Sections 2 and 3 of Core 58. The 79 species identified in this sequence are listed in Appendix Table 16.

The only highly dominant species at this site was largesized Globocassidulina subglobosa, which predominated in the late Eocene but dropped off markedly in the earliest Oligocene. Species which occurred consistently throughout the section include G. subglobosa, Oridorsalus umbonatus, Heterolepa grimsdalei, Bolivinopsis cubensis, and Laticarinina altocamerata. Rotaliatina sulcigera, Anomalinoides alazanensis, Rectuvigerina prisca Finlay, Vulvulina pennatula Batsch, Laticarinina halophora, Brizalina reticulata Hantken, and Stilostomella basicarinata Hornibrook all occurred consistently during parts of the Oligocene.

Substantial faunal overturn characterized the Eocene/ Oligocene boundary interval. Termination of the high dominance of $G$. subglobosa accompanied the extinctions of Cibicidoides parki, Uvigerina rippensis, and several rare lagenids. Occurring just above the boundary were $R$. prisca, Rotaliatina sulcigera, Uvigerina wanzea Finlay, Nuttallides umbonifera, Vulvulina pennatula, Cas- sidulina cuneata Finlay, and Pleurostomella tenuis Hantken.

In the late Oligocene Globigerina angiporoides Zone (equivalent to nannofossil zones NP24-NP25), $R$. sulcigera disappeared, although it reappeared briefly in the Miocene. At this same time (Core 53) several modern species occurred for the first time at this site; these include $H$. kullenbergi, U. spinulosa, U. pigmaea, P. quin$q u e l o b a$, and the variant of $B$. pusilla with several costae which extend almost the length of the test.

\section{Early to middle Miocene}

Despite the relatively good preservation of these sediments, only 69 species were identified (Appendix Table 17). No species becomes dominant, but several occur consistently; these are Globocassidulina subglobosa, Heterolepa kullenbergi, Oridorsalis umbonatus, Hopkinsina mioindex, Pullenia bulloides, Melonis barleeanum, Karreriella bradyi (Cushman), and Brizalina anastomosa (Finlay).

Numerous species first named from sections on New Zealand are found at Site 593, in larger numbers than at any other site. Among these are $H$. mioindex, Anomalinoides orbiculus Stache, Trifarina costornata (Hornibrook), Rectuvigerina striatissima (Stache), Rectuvigerina rerensis Finlay, $R$. vesca, Siphonina australis Finlay and $B$. anastomosa.

A yellow interval, termed the "oxidized zone," was recovered in Cores 593-43 and 593-42, belonging to the Globorotalia miozea Zone, which at this latitude is considered equivalent to nannofossil Zones NN4-NN5. In these sediments $U$. auberiana occurs in large numbers, cibicidids occur in larger numbers than in other samples at this site, and Lenticulina calcar d'Orbigny makes its one and only appearance in the Leg 90 Tasman Sea sites. The spirally limbate Cibicidoides trincherasensis (Bermudez) first occurs in this interval, as do Planulina harangensis Cushman and Ellisor and the more fully striate morphotype of $B$. pusilla. Brizalina anastomosa for the first time is consistently present and common through this interval.

First appearances of several important species occur in Core 40 (G. peripheroacuta Zone). These include Uvigerina rugosa, Nuttallides umbonifera, Alabamina haitiensis, Cibicides wuellerstorfi, Martinottiella communis d'Orbigny, and Bolivinopsis praelonga Schwager.

\section{Middle to late Miocene}

Despite only moderate sediment preservation, faunas from the mid to late Miocene at Site 593 contained the largest assortment of benthic foraminifers of any site at any time. One hundred and two species were identified and are listed in Appendix Table 18. At least 13 of these species were agglutinated and 45 were rectilinear.

Species dominance was pronounced in many samples, but different species were dominant during four discrete times intervals: the early Neogloboquadrina continuosa Zone equivalent to NN6-NN9, the later $N$. continuosa Zone equivalent to NN9-NN11a, the Globorotalia miotumida into the early $G$. conomiozea Zones, equivalent to Zones NN11a partim and NN11b to NN12; and the 
late G. conomiozea Zone. During the earliest interval highly dominant species were Cibicides wuellerstorfi and Rectuvigerina spinea. These were superseded in the late $N$. continuosa Zone by the more ornamented brizalinids Brizalina pusilla and B. finlayi, and during the G. miotumida Zone by the striate brizalinids of the $B$. pusilla group. In the late $G$. conomiozea Zone, however, a very different group of species dominates, including highly dominant miliolids, Heterolepa rugosa, and Uvigerina asperula.

Species which occur throughout the section consistently and in relatively large numbers are $H$. kullenbergi, Oridorsalis umbonatus, Hopkinsina mioindex, Heterolepa rugosa, and Bulimina striata d'Orbigny. Spinose uvigerinids are relatively diverse at this site and $U$. hispi$d a$ is present in most samples of the G. miotumida Zone and later. Striate rectuvigerinids are less frequent; only $R$. ongleyi and $R$. postprandia occur at this site. Osangularia culter and $O$. bengalensis both occur at this site and with the same frequency. The one species unique to this site is the horned cassidulinid, Globocassidulina bicornis Cushman, which occurs only at the very end of the Miocene.

Rather unusual radiolarian-bearing samples are intercalated into the calcareous sequence of the early Neogloboquadrina continuosa Zone in Cores 593-39 to 593-34 and 593-27 to 593-28. These unusual samples contain large amounts of large-sized $N$. umbonifera and floods of small virgulinids. Throughout this interval they alternate with a $R$. spinea-Cibicides wuellerstorfi fauna. At the very end of this episode Pullenia quinqueloba joins the $N$. umbonifera fauna. Both of these species are more frequent at deeper-water Sites 591 and 586, except at this time.

\section{Pliocene}

The 85 species identified in the Pliocene at Site 593 are listed in Appendix Table 19. These faunas occurred in sediments which were generally well preserved throughout. Approximately 33 species were rectilinear and 10 were agglutinated.

The dominant species of the early Pliocene was $U v i$ gerina hispida. The miliolids, particularly Pyrgo murrhina, and Pullenia bulloides dominated samples during the later Pliocene. The most consistently occurring species, however, were Heterolepa kullenbergi, H. rugosa, Textularia lythostrota, Cibicidoides $\mathrm{cf}$. ungerianus, and Oridorsalis umbonatus. Various miliolids also were present throughout and were much more common here than in Site 592 some $5^{\circ}$ farther to the north.

Faunal overturn is concentrated at a level equivalent to the nannofossil NN15/NN16 boundary in the $G$. inflata Zone. Hopkinsina mioindex, C. cicatricosus, Brizalina reticulata, and Siphonina australis all disappear permanently from the faunas at this time. Coincidentally, Cibicides wuellerstorfi and Osangularia bengalensis return to the faunas, both having been absent since the latest Miocene. Diversity (species richness) and the percentages of rectilinear species also increase at this same level $(593-8, C C)$.

\section{Site 594}

An entirely different sedimentary sequence was recovered at Site 594, including radiolarian oozes with greater or lesser amounts of hemipelagic input. These hemipelagic sediments include large amounts of mica, volcanic glass, and quartz. In the majority of samples prior to the Pliocene the calcareous fossils are poorly preserved; at some levels few if any calcareous particles could be identified. The fact that each sediment type contained a unique foraminiferal fauna explains the disjunct distributions seen in Appendix Tables 20 to 22 .

\section{Early to middle Miocene}

Throughout this interval benthic foraminiferal faunas are poorly preserved. They occur in radiolarian oozes which contain large amounts of diatoms and sponge spicules. In a few samples there is enough carbonate material to qualify the sediments as a radiolarian-foraminifer ooze. Frequently these siliceous oozes contain large amounts of mica, quartz, and glass. Carbonate material is relatively common.

Along with the variable lithologies, the benthic faunas are varied and species distributions are disjunct (see Appendix Table 20). In the radiolarian oozes containing the least amount of carbonate material, resistant benthic species are Cassidulina crassa, Stilostomella lepidu$l a$, and Stilostomella pomuligera Stache. This fauna is entirely different from the solution-resistant fauna in dissolved carbonate oozes; in generic composition it closely resembles faunas from radiolarian-rich levels in the Oceanic Formation of Barbados.

When sediments contain large amounts of hemipelagic materials, benthic faunas consist of many specimens of Heterolepa kullenbergi, Anomalinoides globulosa, several species of Stilostomella, Bolivinopsis praelonga, and Uvigerina spinulosa. Bolivinopsis praelonga is the dominant species in such samples.

In samples containing larger amounts of carbonate, benthic foraminifers are more diverse. Common species include Brizalina finlayi, Globocassidulina subglobosa, Hopkinsina mioindex, relatively frequent cibicidids, species of Laticarinina, and Trifarina. Samples of this sort in Cores 40-45 and 47-50 contain huge specimens of $N$. umbonifera which are very commonly accompanied by spherical, ornamented radiolarians.

\section{Middle to late Miocene}

Sixty-two species of benthic foraminifers were identified from the fairly well to poorly preserved sediments (Appendix Table 21). Most samples contain large amounts of radiolarians, mica, and siliceous spicules, and the carbonate is largely dissolved, leaving only fine-fraction residues in many cases.

In such lithologies, benthic faunas have large numbers of a few highly dominant species, including Heterolepa kullenbergi, Uvigerina auberiana, and Nuttalides umbonifera. Species very frequent, but not dominant, include Bolivinopsis praelonga, Brizalina reticulata, and Oridorsalis umbonatus. The only species consistently pres- 
ent throughout this time interval is Bolivinopsis praelonga.

The species of Bulimina differ in these levels from those at other sites and/or at other times. Bulimina truncana is relatively rare and $B$. striata is common. Bulimina aculeata, present only at Site 593 and here, first occurs during the early part of the Globorotalia miotumida Zone equivalent to nannofossil zones NN7-NN8, in radiolarian ooze.

As at other sites, the uvigerinids become particularly abundant and more diverse at the end of the Miocene (Appendix Table 21). The hispid species $U$. auberiana, very frequent at the beginning of this interval, is gradually replaced by spinose types such as $U$. proboscidea and $U$. aculeata toward the end of the Miocene. At the very end, the hispido-costate form U. hispido-costata predominates, along with the coarsely spinose $U$. hispida.

Miliolids appear at the end of the Miocene along with the hispido-costate uvigerinids. They occur in samples composed largely of radiolarians and spicules along with another, typically deeper water species, Pullenia quinqueloba. Unique to this site is Hoeglundina elegans (d'Orbigny), which becomes more frequent later in the Pliocene.

Unusual benthic faunas (Cores 594-36 to 594-38) are composed almost totally of giant-sized specimens of $N$. umbonifera accompanied by an occasional specimen of $P$. quinqueloba, in a matrix of spherical radiolarians. Although similar to the $N$. umbonifera-radiolarian samples of the early Miocene, the size and numbers of $N$. umbonifera in these samples are much greater.

\section{Pliocene}

In the Pliocene the benthic foraminiferal faunas are more diverse (See Appendix Table 22) because there are more carbonate-rich samples and less dissolution. Preservation varies from fair to moderate throughout the Pliocene. In the latest Pliocene (and in the Pleistocene, not discussed in this report) there are two distinct carbonate lithologies: in the first, foraminifers are opaque, and large amounts of hemipelagic sediments may be present; in the second, the foraminifers are clear and glassy, and the sediment is largely carbonate. Both lithologies contain distinctive foraminiferal faunas.

Carbonate and siliceous sediments alternate from core to core and contain different benthic faunas. In the earliest Pliocene, sediments composed entirely of radiolarians and some benthic foraminifers contain frequent specimens of Sigmoilopsis schlumbergeri, along with solutionresistant, cosmopolitan forms such as Globocassidulina subglobosa, Oridorsalis umbonatus, and Heterolepa kullenbergi. Carbonate samples of this age are rich in uvigerinids (only a few of which are rectuvigerinids), have high benthic diversity, and a fauna typical of the $1000-\mathrm{m}$ depth sites in the Tasman Sea.

Higher in the Pliocene, in sediments which contain not only radiolarians but diatoms and detrital micas, quartz, and glauconite, an entirely new, unique benthic fauna occurs. In Core 594-6 Bulimina aculeata becomes common, accompanying a new species of Bolivinita in
Core 594-10; it occurs with large amounts of Trifarina angulosa and/or T. eximia, which are opaque.

In Core 594-12 in samples composed primarily of hemipelagic sediments, Hoeglundina elegans is accompanied by relatively large numbers of cassidulinids belonging to either of the species Cassidulina crassa or $C$. laevigata carinata, Brizalina alata (Sequenza), S. lepidu$l a$, and several lagenids.

Unlike other sites, the Pliocene at Site 594 is dominated by the hispido-costate uvigerinids, has̀ at least one sample (594-14-3, $19 \mathrm{~cm}$ ) dominated by Melonis pompilioides, and contains faunas similar to those at DSDP Site 532, located under the west African upwelling and receiving large amounts of detrital sediments from the African continent (Boersma, 1984c).

\section{BIOSTRATIGRAPHY}

The stratigraphic ranges of the most common benthic foraminifers have been extracted from Appendix Tables 1-22 and are shown in Figure 2; Figure 3 depicts only the ranges of all uvigerinids. Because of the large latitudinal range of the sites, correlation was difficult. This difficulty was compounded by the fact that the foraminiferal zones became longer and fewer at the two highest latitude Sites 594 and 593. Although use of the nannofossil zones, particularly at Site 594, was also problematic, their greater number and their reputation for better synchrony through latitude seemed to provide the better means for intersite correlation. Therefore, the ranges of the benthics are interpreted using the nannofossil biostratigraphy.

Because the total stratigraphic ranges of many bathyal benthic foraminifers are not yet known, it has not been possible to establish first or last appearances in the evolutionary sense. The majority of species occurrences in these sites are probably ecologically controlled events. Exceptions, that is, appearances likely to be evolutionary originations, are discussed later.

The majority of changes across the Eocene/Oligocene boundary involve faunal reorganization, changes in dominant species, or the reappearance of species already present in the late Eocene of either Sites 592 or 593. At both sites, however, Cibicidoides parki and Uvigerina rippensis disappear at the boundary, and U. pigmaea appears just above it. Based on my extensive knowledge of uvigerinids, it is possible to state that these are first and last occurrence datums of the uvigerinids, and probably the LAD of $C$. parki as well.

The Oligocene, and particularly the late Oligocene, is characterized by disappearances of typically Eocene species such as Bolivinopsis cubensis, Heterolepa grimsdalei, Marginulinopsis hochstetteri, Rectuvigerina pris$c a$, and a cibicidid transitional to $H$. kullenbergi. Rotaliatina sulcigera, which in New Zealand sections is a good index for the early Oligocene, ranges in the Tasman Sea to the mid-Oligocene at Site 592, but into early Miocene Zone NN2 at Site 593.

The one notable species to originate in the Oligocene is $H$. kullenbergi, which first appeared during the Interval Zone NP24/NP25 at Sites 593 and 588 . The fact 


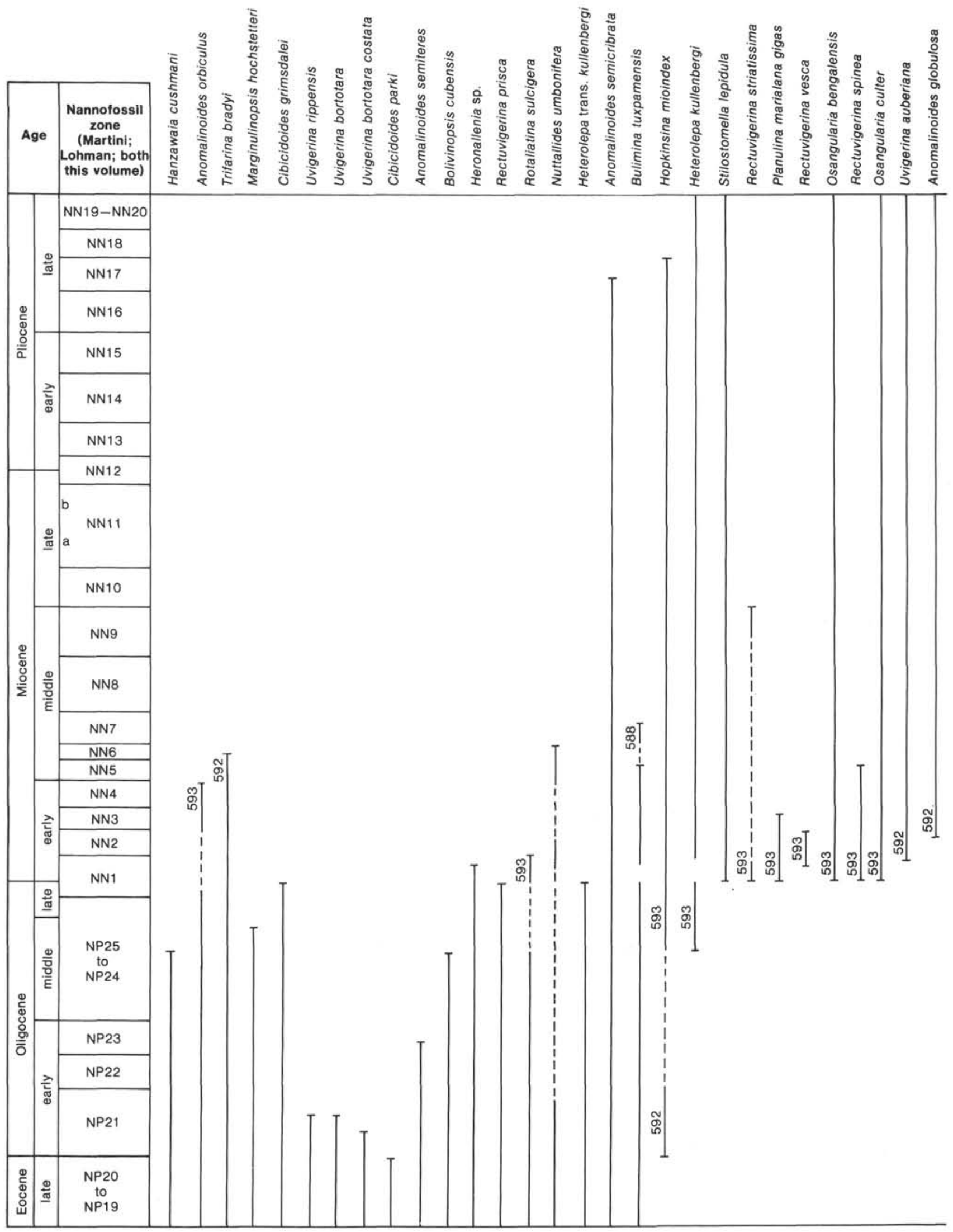

Figure 2. Stratigraphic ranges of benthic foraminifers through the Tertiary at Leg 90 sites in the Tasman Sea, Coral Sea, and on the Chatham Rise. Ranges are combined from all the range data in Appendix Tables 1-22. Biostratigraphic zonation follows Martini; Lohman; both this volume. 


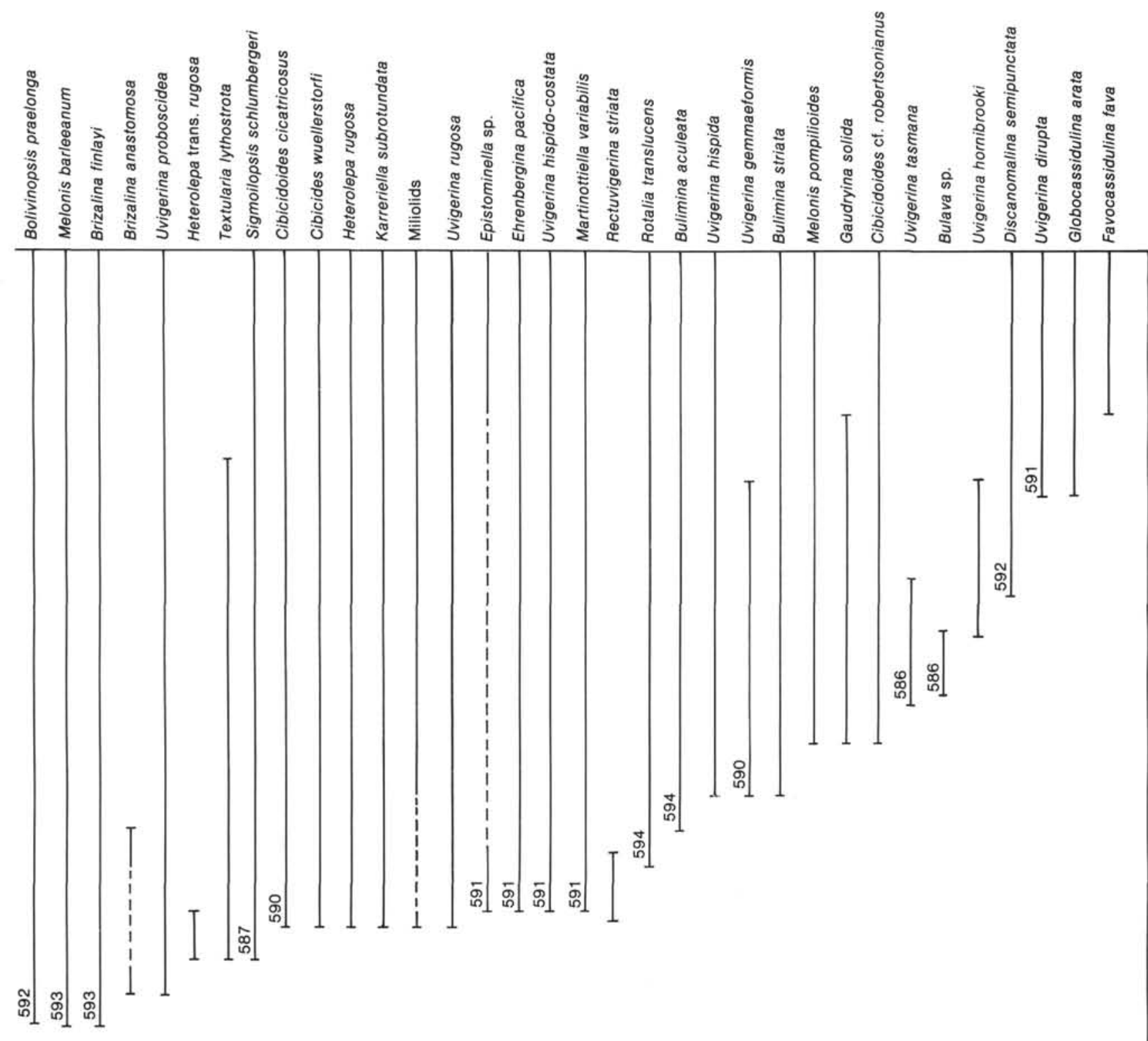

Figure 2. (Continued). 


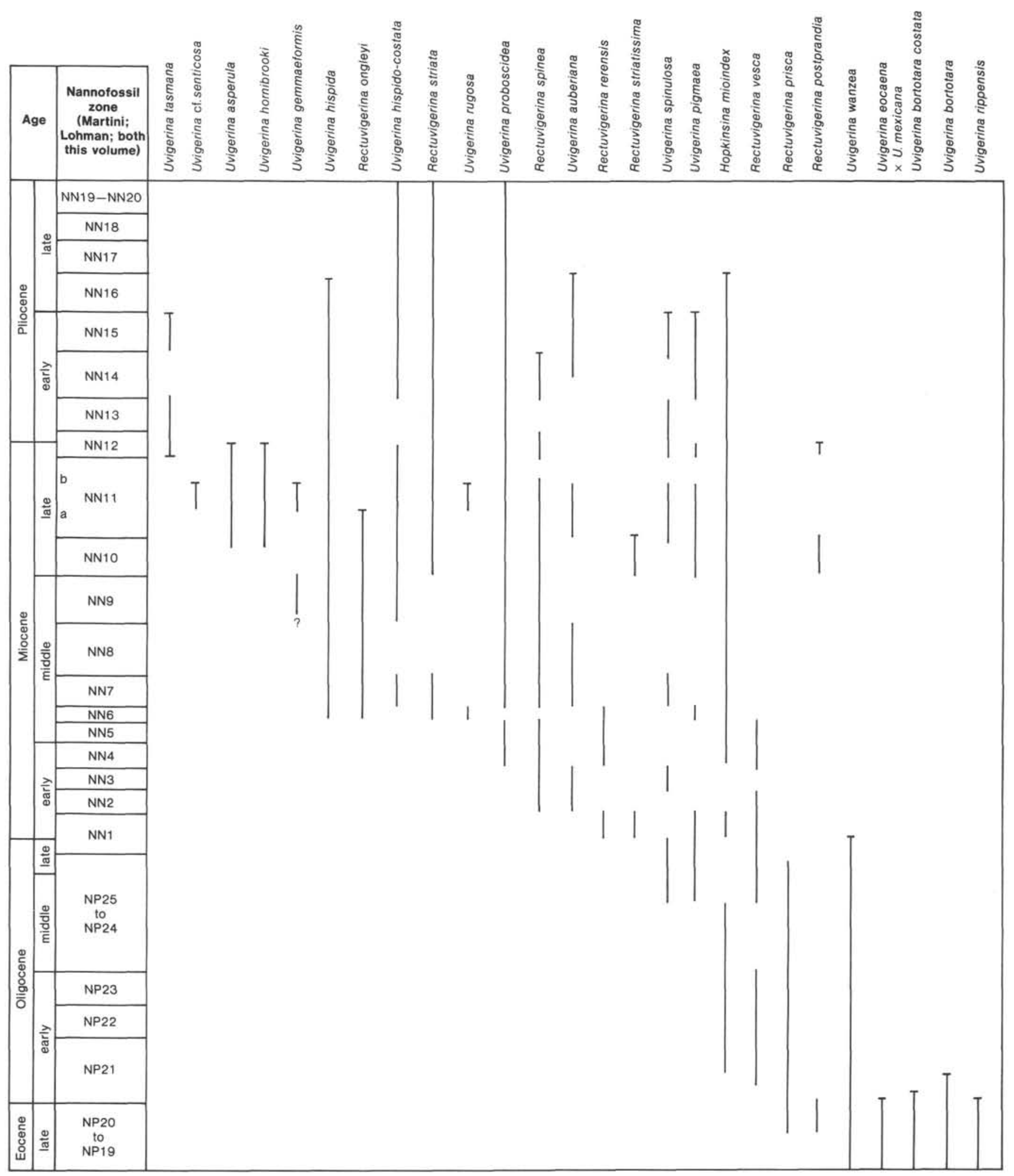

Figure 3. Stratigraphic ranges of species of the genera Uvigerina and Rectuvigerina through the Tertiary in the Tasman Sea, the Coral Sea, and on the Chatham Rise. Biostratigraphic zonation follows Martini; Lohman; both this volume. 
that this species first occurs during the late Oligocene in other areas, for example at Sites 516 and 526 in the South Atlantic (Tjalsma, 1983; Boersma, 1984b), suggests that its appearance here may be an evolutionary event.

Approximately 20 species first appear during the course of the early Miocene. Seven of these, occurring synchronously during Zone NN1 at Sites 588 and 593, include species of the genera Osangularia, Uvigerina, Rectuvigerina, and Brizalina. These newly evolved species tend to predominate in the few well-preserved samples of early Miocene age. A relatively thin species of Melonis, tentatively referred to $M$. barleeanum, also first occurs at this time at both sites.

Several typically Paleogene buliminids disappear during the course of the early to middle Miocene. Of these, Bulimina tuxpamensis disappears diachronously through the Tasman Sea, persisting longest at Site 588, where it lasts until the middle Miocene (Zone NN8). Heronallenia sp. and Rotaliatina sulcigera disappear in Zones NN1 and NN2, respectively.

The largest number of first appearances of the entire Tertiary was found during Zones NN5/NN6, and to a lesser degree, Zone NN7. Of the 13 new taxa, 5 belong to the cibicidids and 3 to the uvigerinids. The appearance of Cibicides wuellerstorfi, Heterolepa rugosa, and C. cicatricosus in Zones NN5/NN6 and of Rectuvigerina striata and Rotalia translucens in Zone NN7 are considered first appearance datums. It is interesting that all of the originations during Zone NN7 took place at the deeper-water Site 591.

Primarily buliminids and uvigerinids appear during the course of the middle Miocene. Bulimina aculeata, later typical of both higher-latitude Sites 593 and 594, first occurs at Site 594 and reaches 593 only by the later Miocene.

Melonis pompilioides, a species more common at the two deeper-water Sites 586 and 591, first appears at Site 591 in Zone NN10; its occurrence at shallower sites is delayed until Zone NN11. Few other species first occur during the late Miocene, with the notable exception of a bizarre genus, Bulava, first named from Ninetyeast Ridge in the Indian Ocean, where it ranges through middle and late Miocene (Boltovskoy, 1978). At Site 586 Bulava occurs only in Zone NN11a. Also at Site 586 a new species, U. tasmana, first evolves. It ranges through late Miocene Zones NN11-NN12.

At the very end of the Miocene, in levels dominated by miliolids and uvigerinids at all sites, a spined anomalinid, Discanomalina semipunctata, first appears and ranges into the Pliocene.

Only two new species appear in the Pliocene, both at the deeper-water Site 591. A reticulate form, Globocassidulina arata, first appears in Zone NN14 at the two deeper Sites 591 and 586 and remains confined to these deeper areas. Uvigerina dirupta, a very common Pleistocene to Recent species worldwide, first appears at Site 591 in Zone NN14, but spreads to several other sites diachronously through the course of the Pliocene. This is probably the first appearance datum of this species.

\section{BIOGEOGRAPHY}

The preceding faunal descriptions indicate several species or genera whose presence, absence, and frequency suggest depth and latitudinal provincialization. Lacking other quantitative data, frequency, normalized for sample number, was computed for several species, genera, or cohesive groups of species. In this discussion, all of the sites whose depth was approximately $1,000 \mathrm{~m}$ will be termed mid-bathyal, and the two deeper Sites 591 and 586 , located near $2,000 \mathrm{~m}$ paleodepth, will be called lower bathyal.

\section{Osangularids}

The distributions of the genus Osangularia and its two species show the most pronounced latitudinal trends of any of the benthic foraminifers. The genus (Fig. 4) is less frequent with increasing latitude; it is absent altogether in the early Miocene at Sites 593 and outside the Tasman Sea, at Site 594. The gradient toward higher frequency at lower latitudes increases through the later Miocene. In the Pliocene the genus appears more commonly at lower bathyal Site 591 and most commonly at adjacent middle bathyal Site 590 . The two species, $O$. bengalensis and $O$. culter, behave inversely through latitude (Fig. 5). Osangularia culter is more frequent at mid to higher middle latitudes, whereas $O$. bengalensis is more frequent both at lower latitudes and at greater depths.

\section{Miliolids}

Like the osangularids, the porcellaneous miliolids demonstrate latitudinal frequency gradients; they appear more commonly at higher latitudes. The miliolids first occur in the lower bathyal zone and are more common there than in the mid-bathyal sites. Like the osangularids, this group increases in import and frequency after the early Miocene.

\section{Brizalinids}

Among the brizalinid species there is a trend toward greater, thicker reticulation at higher latitudes. Peripheral flanges such as those on Brizalina aenariensis and dense striations are more typical of equatorial latitudes. A frequency gradient increasing toward Site 593 is maintained throughout the Miocene and Pliocene (shown in Fig. 7, later), despite the marked decrease in brizalinid abundance after the early Miocene. In the Pliocene, the number of species at Site 593 is greater and their frequency still increases at Sites 593 and 592 at this time.

\section{Lower Bathyal Species-the "Deep Group"}

Because of their greater frequency at the two lower bathyal Sites 591 and 586, a suite of six species has been termed the lower bathyal group. Figure 6 indicates their concentration at the two deeper-water sites. When these species do occur at the mid-bathyal sites, it is in pulses, at least some of which appear to be related to the several steps in the buildup of polar glaciation. These species are Melonis pompilioides, Stilostomella subspinosa, Pul- 

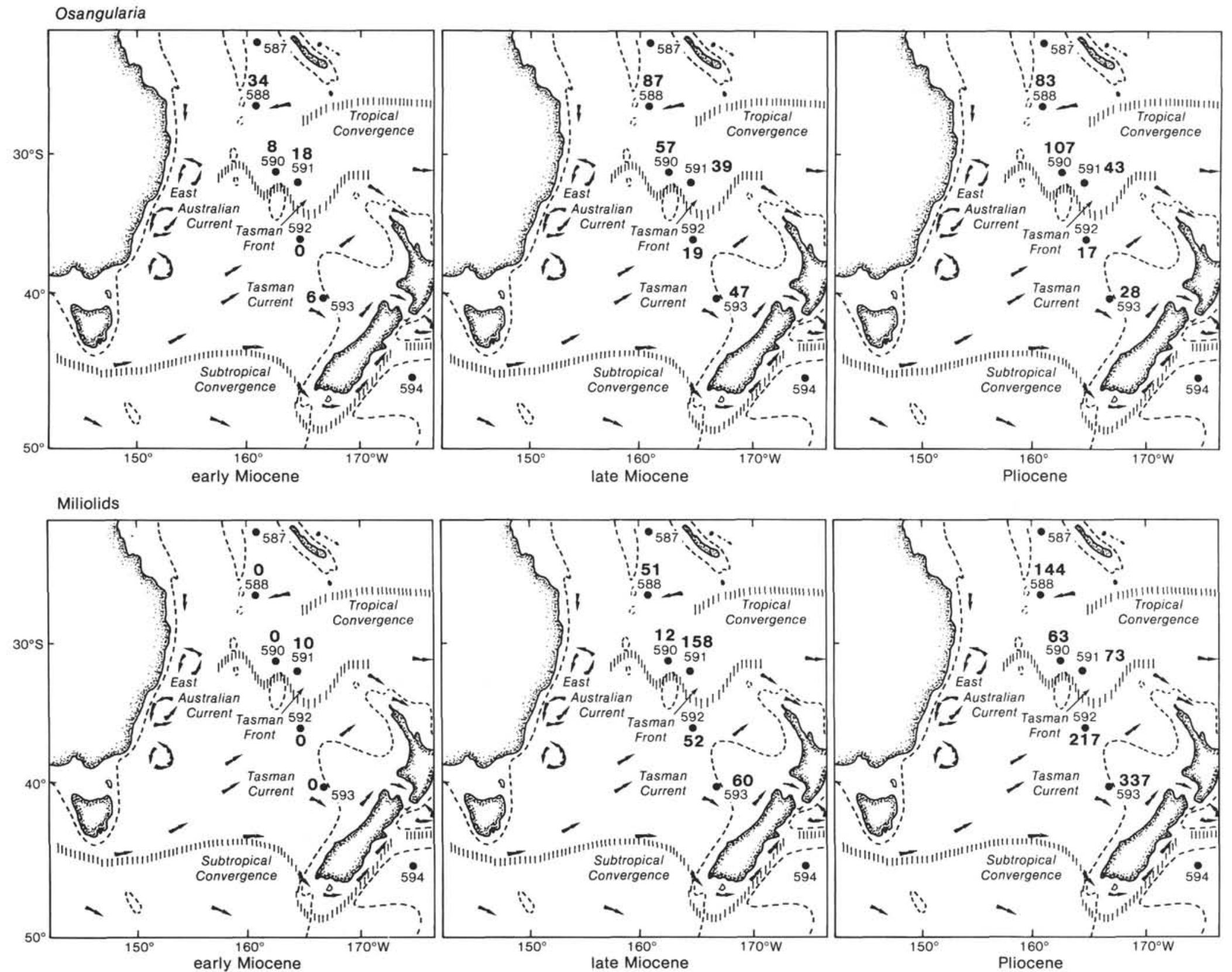

Figure 4. Frequency of osangularids and miliolids in the early and late Miocene and the Pliocene in the Tasman Sea. The number of total occurrences is normalized to the number of samples examined, and expressed as a percentage. 

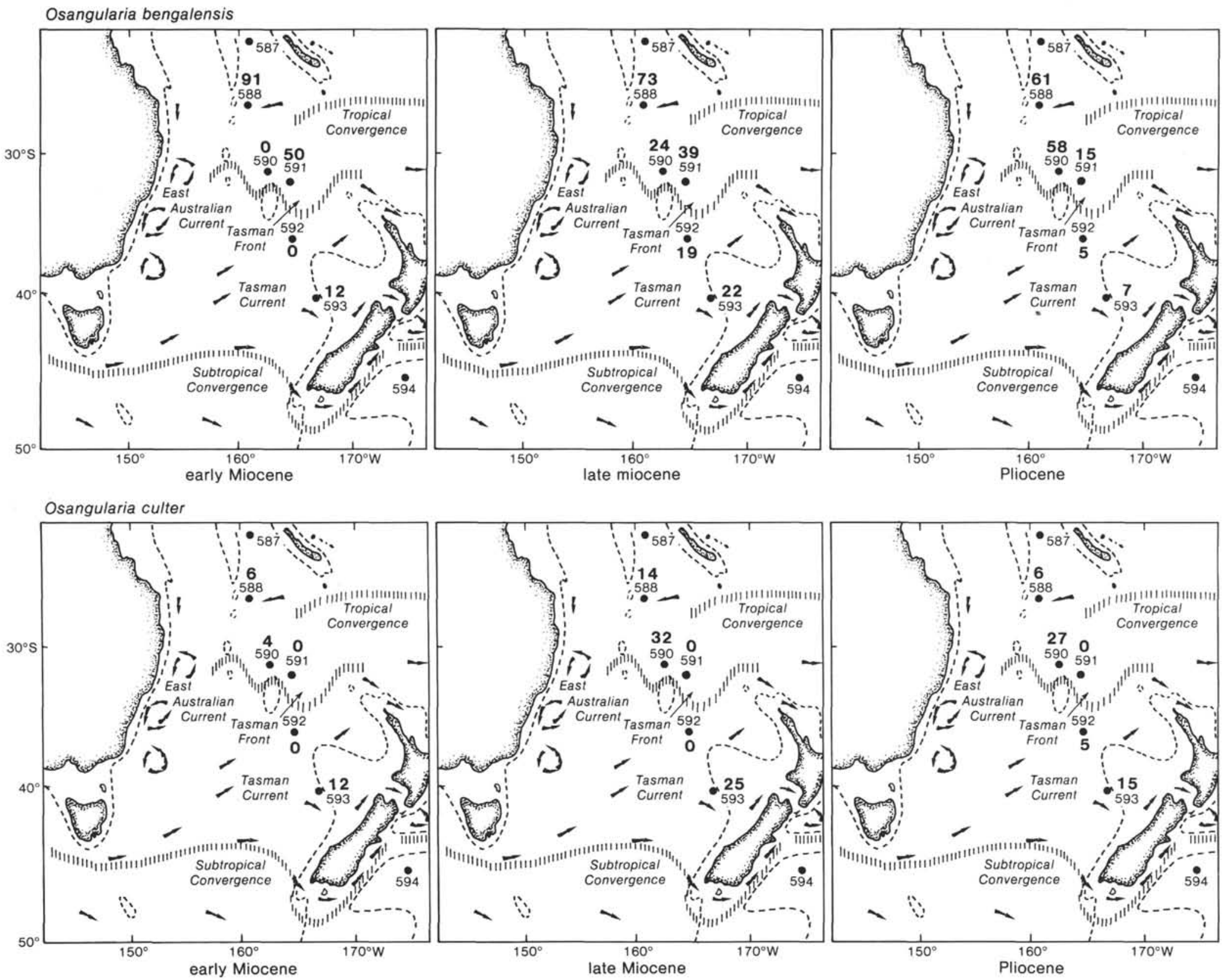

Figure 5. Frequency of the two species Osangularia in the early and late Miocene and the Pliocene in the Tasman Sea. Percentages determined as in Figure 4. 

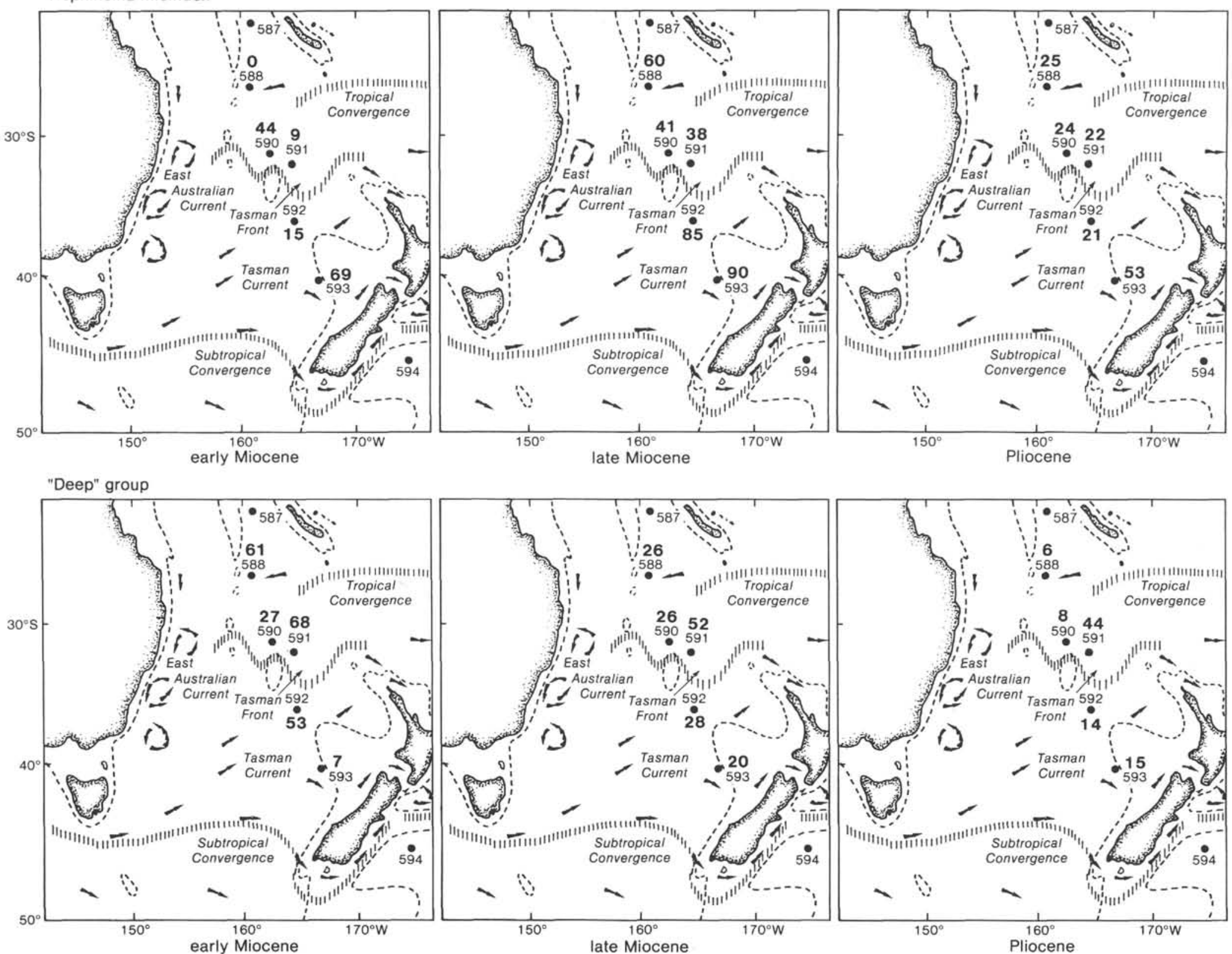

Figure 6. Frequency of Hopkinsina mioindex and the "deeper" group of benthics in the early and late Miocene and the Pliocene in the Tasman Sea. The deeper group of species includes Melonis pompilioides, Pullenia quinqueloba, Uvigerina hispido-costata, Nuttallides umbonifera, Stilostomella subspinosa, and Melonis sphaeroides. Percentages determined as in Figure 4. 
lenia quinqueloba, M. sphaeroides, Uvigerina hispidocostata, and Nuttallides umbonifera.

\section{Cibicidids}

This group provided the largest taxonomic problems, with the result that only about one-half of the species could be positively identified. The group is much more diversified in the Pacific than in the Atlantic during the Neogene. At mid-bathyal sites, the overall diversity of cibicidids decreases from the early Miocene into the Pliocene; for example, early Miocene samples at Site 593 contain 10 species, contrasted to an average of 3 in the Pliocene (Fig. 7). The opposite pattern emerges at Site 591, where cibicidid diversity increases from the early Miocene into the Pliocene. The few Pliocene species, however, become much more abundant, particularly at the very end of the Pliocene.

Species of Planulina and Cibicides are equally distributed at each site. Heterolepa is the most frequently occurring genus, and $H$. kullenbergi the most common species. The only species limited to the mid-bathyal zone was Cibicidoides tuxpamensis. Other patterns in the numbers of species or types at different sites are difficult to recognize. A decrease in the number of species with depth is illustrated in Figure 7.

\section{Hopkinsina mioindex}

In general, $H$. mioindex is both more abundant and more frequent at Site 593 (Fig. 6). It decreases in frequency in lower latitudes and in the lower bathyal zone, where it occurs only in pulses, the most intense of which was in the late Pliocene.

The inferred depth or latitudinal preferences of several other species or species groups are depicted qualitatively in Figure 8. Species apparently preferring lowerlatitude, mid-bathyal regions include the very finely striate rectuvigerinids, Globocassidulina arata, Uvigerina tasmana, and Brizalina aenariensis. Those which flourish toward higher middle latitudes in the mid-bathyal zone are Discanomalina semipunctata, Bulimina aculeata, Bolivinita pliozea, Hoeglundina elegans, and the coarsely striate rectuvigerinids such as Rectuvigerina pris$c a$ and $R$. postprandia.

Depth preferences are depicted qualitatively in Figure 9. Melonis sphaeroides and Bulimina consanguinea are restricted to the lower bathyal zone. Only the costate uvigerinids such as $U$. hornibrooki and $U$. tasmana are confined to the mid-bathyal zone. Other species which have strong depth correlation nevertheless transcend depth in discrete pulses relatable to oceanographic changes in the area.

Species restricted to the hemipelagic environment of Site 594 include Brizalina alata, Trifarina eximia, and Sigmavirgulina tortuosa. Only in this environment do Bulimina aculeata, M. pompilioides, and T. angulosa occur in floods. Of the cibicidids, Cibicides wuellerstor$f i$ is the most common species. This species is concentrated in other hemipelagic areas, for example, DSDP Site 532 off Angola; and in the nutrient-rich peripheral areas of the North Pacific Ocean (Woodruff and Douglas, 1981).

\section{COMPARATIVE FAUNAL HISTORIES AND SUMMARY}

In general, Tasman Sea benthic foraminiferal faunas contain large percentages of cosmopolitan species including Oridorsalis umbonatus, Globocassidulina subglobosa, Stilostomella lepidula, Hopkinsina mioindex, Pullenia bulloides, Sphaeroidina bulloides, Eggerella bradyi, and Heterolepa kullenbergi. The numbers of stilostomellids, uvigerinids, brizalinids, cibicidids, and anomalinids are usually high, the numbers of buliminids, lagenids, and lenticulinids are low. Very similar Neogene faunas have been reported from Car Nicobar (Srinivasan and Sharma, 1980), from the Ninetyeast Ridge in the Indian Ocean (Boltovskoy, 1978), and from Site 289 on the Ontong-Java Plateau (Woodruff, 1979). Faunas of the later Neogene on the Chatham Rise are similar to those from the carbonate sediments at DSDP Site 532 located under an eastern boundary upwelling off the coast of Angola (Boersma, 1984c).

Unique to Tasman Sea faunas, particularly in the Paleogene, are the large numbers of austral species originally named from New Zealand (Finlay, 1939), the large ornamented nodosarids such as Nodosaria costornata and $N$. scalaris (see Plate 13) first named from Car Nicobar (Schwager, 1866), and the very high numbers of uvigerinids and miliolids. Austral species include, inter alia, Bolivinita pliozea, Rectuvigerina rerensis, $R$. ves$c a, R$. striatissima, Cibicidoides notocenicus, Uvigerina bortotara, Rotaliatina sulcigera, Siphonina australis, Trifarina costornata, Anomalinoides orbiculus, Brizalina anastomosa, B. finlayi, $R$. prisca, U. wanzea, Stilostomella basispinata, and Margulinopsis hochstetteri. Although spinose uvigerinids occurred in large numbers worldwide during the late Miocene Globorotalia plesiotumida Zone (Lutze, 1978; Woodruff and Savin, 1981; Vincent et al., 1980), their abundance and persistence, along with marked decreases in Cibicides wuellerstorfi and Globocassidulina subglobosa but relatively diverse rectuvigerinid and miliolid faunas, is unique to the Tasman Sea.

Diversity (species richness) of Tasman Sea faunas varies from a low near 63 to a high near 102 species per series. Diversities, particularly in the early Miocene at lower-latitude Site 588, are somewhat higher than in Atlantic Ocean middle bathyal oceanic regions such as Site 526 on the Walvis Ridge, but similar to those on the Ninetyeast Ridge (Boltovskoy, 1978; Boersma, 1984b). However, from the late Oligocene through late Pliocene, the number of individuals per gram of sediment (the Benthic Number) is especially high in the Tasman Sea compared with these other intermediate-depth, open ocean areas.

\section{Paleogene}

The Paleogene was drilled in Hole 588C and Sites 592 and 593 , but the record at 588 is obscured by diagenesis. In the latest Eocene, there is marked faunal and sedimentary differentiation between the closely situated Sites 592 and 593. Faunas at Site 592 contained large numbers of cibicidid species and were dominated by species 

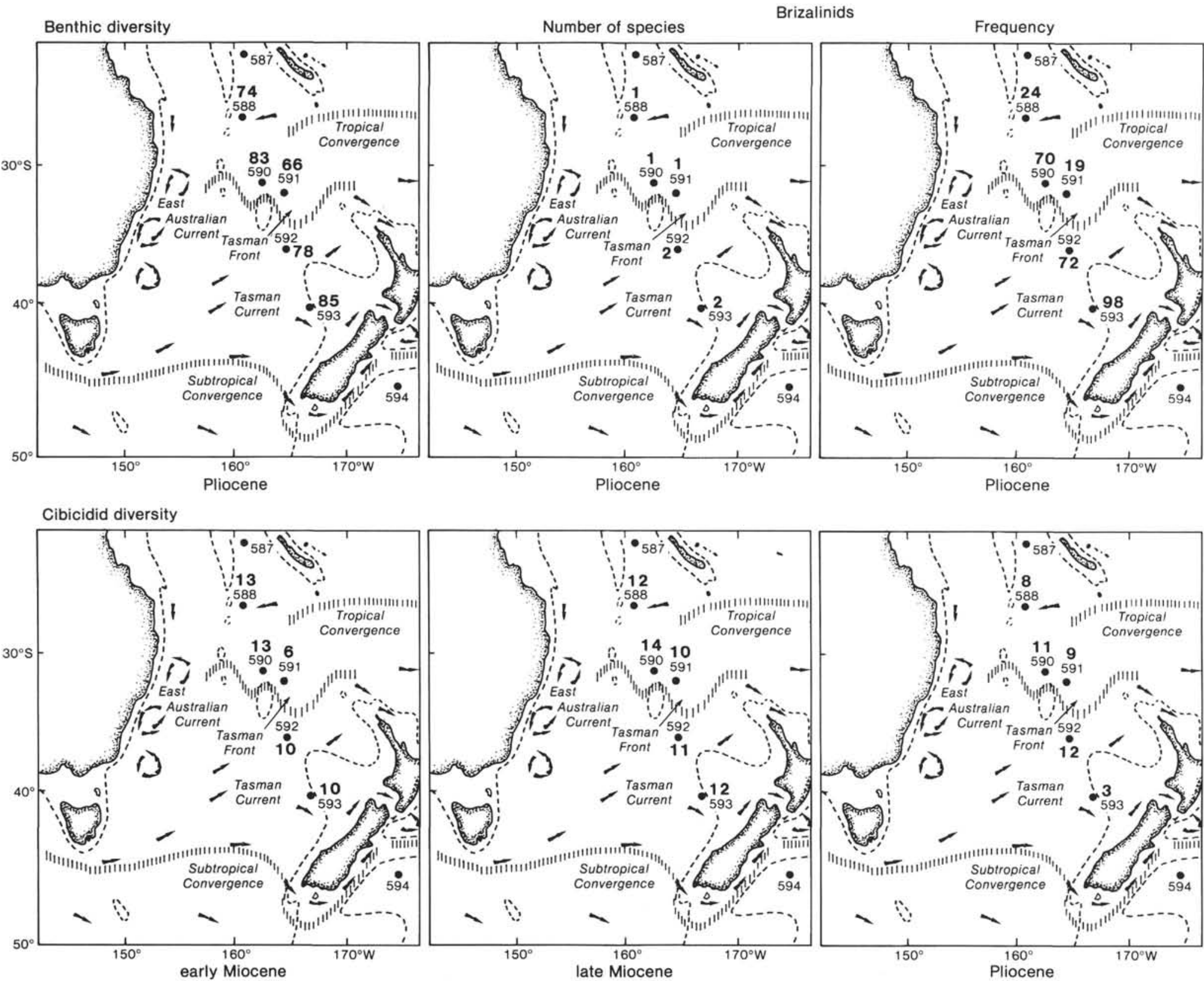

Figure 7. Benthic diversity, expressed as species richness, in the Pliocene of the Tasman Sea. Frequency and numbers of species of Brizalina during the Pliocene. Numbers of cibicidid species in the early, late Miocene, and Pliocene throughout the Tasman Sea. Genera included in this estimate are Cibicides, Planulina, Cibicidoides, and Heterolepa. Percentages determined as in Figure 4. 


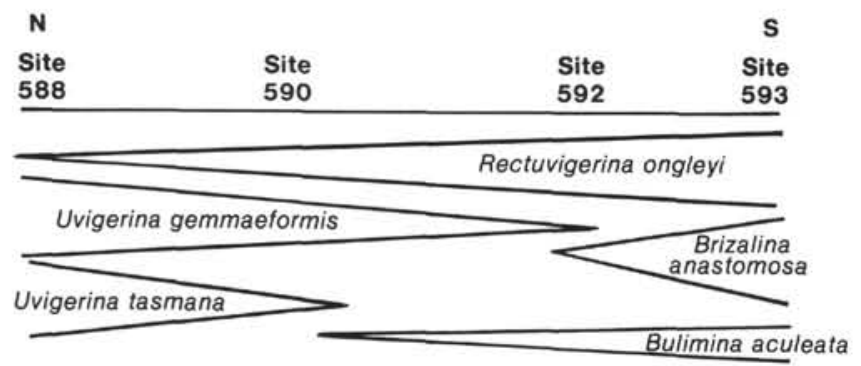

Discanomalina semipunctata

Nuttalides umbonifera

Figure 8. Schematic depiction of the abundance, with latitude, of seven benthic foraminiferal species through the mid-bathyal sites in the Tasman Sea. This geographic provincialization occurs between $21^{\circ}$ and $35^{\circ} \mathrm{S}$. Increasing species abundance is indicated by widening, diminishing abundance by narrowing of the $\mathrm{V}$.

$\mathbf{N}$

\begin{tabular}{ll} 
Site & Site \\
590 & 591 \\
\hline
\end{tabular}

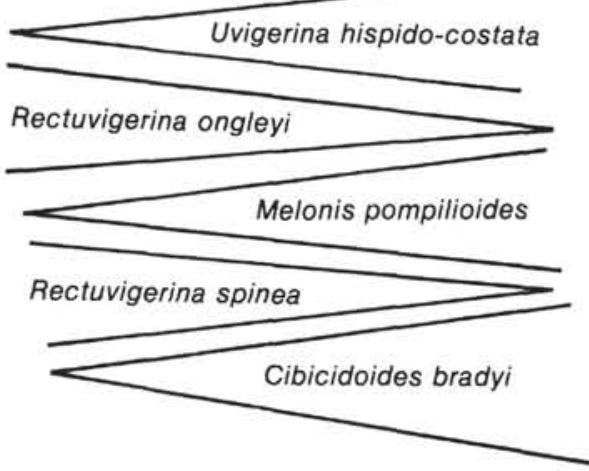

Figure 9. Schematic depiction of the abundance with depth of five benthic foraminiferal species through the mid- to lower bathyal zone in the Tasman Sea. Increasing species abundance is indicated by widening, diminishing abundance by narrowing of the $\mathrm{V}$.

of Anomalinoides, such as $A$. aragonensis, and by the spinocostate uvigerinid, $U$. bortotara. By contrast, at Site 593, more species typical of New Zealand land sections, larger specimens of Marginulinopsis hochstetteri, and very large and abundant specimens of Globocassidulina subglobosa characterize most faunas.

Faunal overturn is similar at the two sites at the Eocene/Oligocene boundary when Cibicidoides parki and Uvigerina rippensis both become extinct, whereas Sphaeroidina bulloides, U. pigmaea, Rectuvigerina prisca, Laticarinina altocamerata, L. halophora, and Rotaliatina sulcigera first appear. However, faunal compositional and sedimentary changes are different at the two sites. At Site 593 large $G$. subglobosa disappears, whereas Nuttalides umbonifera occurs in a short pulse at the boundary. Most uvigerinids, except for an unusual smooth species, disappear at the boundary, but return immediately above. Faunas above the boundary are characterized by large numbers of cibicidids, anomalinids, and $O$. umbonatus. At Site 592 the boundary is punctuated by a pulse of radiolarians and spino-costate uvigerinids, followed by the disappearance of the uvigerinids and Pullenia bulloides. For the first time, O. umbonatus becomes the dominant species in a fauna characterized by anomalinids such as $A$. orbiculus, stilostomellids such as Stilostomella basispinata, and the rectuvigerinids.

Early Oligocene faunas are more homogeneous than those of the late Eocene. At both sites generalists, cibicidids, anomalinids, and $O$. umbonatus are common faunal elements. In Zone NP21, the remaining uvigerinids are replaced in import by rectuvigerinids, many of which, like Rectuvigerina postprandia, were originally named in New Zealand (Hornibrook, 1971).

Late Oligocene faunas of Zones NP24/NP25 were found at Site 593 and in very recrystallized sediments in Hole 588C. A marked change in faunas at Site 593 is characterized by a decrease in anomalinids and cibicidids, the extinctions of such Eocene holdovers as $M$. hochstetteri and Cibicidoides notocenicus, the temporary disappearance of $R$. sulcigera, and the appearance of a number of typically Neogene species such as Heterolepa kullenbergi, Hopkinsina mioindex, Pullenia quinqueloba, Brizalina pusilla, and Eggerella bradyi. Here, as in New Zealand, $R$. sulcigera disappears from faunas in the middle Oligocene; however, this taxon returns for a short time in early Miocene faunas (Zones NN1-NN2) at Site 593 before its final disappearance from the Tasman Sea. Despite very poor preservation, the first specimens of $H$. kullenbergi, $H$. mioindex, $P$. quinqueloba, Textularia lythostrota, and $C$. cf. wuellerstorfi are found in Hole $588 \mathrm{C}$ in the late Oligocene.

Preservation at all but Site 593 is poor to barely moderate through the early Miocene. Solution-residue faunas at all sites are strongly dominated by a few resistant species such as $H$. kullenbergi, S. lepidula, O. umbonatus, E.bradyi, and G. subglobosa. Nuttallides umbonifera first occurs, at the base of the section only, at Site 588 and appears in small numbers in several samples through the early Miocene. In the South Atlantic also, $N$. umbonifera migrates into mid-bathyal sites in the earliest Miocene (Tjalsma, 1983; Boersma, 1984b). By contrast, this species does not occur at the deeper-water Site 591 until Zone NN5. Several Oligocene holdovers such as Bulimina semicostata, B. jarvisi, and $R$. sulcigera become extinct through this time interval, but poor preservation make it impossible to specify their endpoints.

By contrast, the moderately well preserved faunas at Site 593 contain new species of cibicidids and a relatively large number of species typical of New Zealand, including Rectuvigerina vesca, $R$. rerensis, Brizalina anastomosa, B. finlayi, and Siphonina australis. At this time the brizalinids become established as consistent and highly dominant faunal elements at Site 593. The elongate rectuvigerinids of the $R$. striatissima-R. rerensis type were located at Site 593, whereas the forms related to $R$. ongleyi and $R$. spinea were confined to lower latitudes at Site 588. Despite the superior preservation, species richness at Site 593 was lower (67 species) than in the very poorly preserved sediments at Site 588 , which contained 93 species. 
Major evolutionary overturn, species migration, faunal reorganization, and depth or latitudinal compartmentalization characterized the beginning of the middle Miocene (NN5-NN6) at all sites, including Site 594 on the Chatham Rise. This corresponds to a global episode of climatic and benthic faunal change attributed to the development of permanent Antarctic glaciation (Shackleton and Kennett, 1975; Woodruff and Douglas, 1981; Boltovskoy, 1978; Boersma, 1984b). Evolutionary overturn involved originations rather than extinctions. Twelve new species appeared at Sites 591 and 592 , but only six at the middle bathyal Site 593 (Fig. 2). These include Pleurostomella alternans, Anomalinoides globulosa, Cassidulina laevigata carinata, Cibicides wuellerstorfi, and Heterolepo rugosa. Heterolepa rugosa occurred only at lower-latitude sites, but $C$. wuellerstorfi first occurred synchronously at all sites in the Tasman Sea. Uvigerina hispido-costata, which first evolved slightly later at Site 591 only, became common along with several newly evolved miliolids. Nuttallides umbonifera reappeared at all but Site 588, and became very abundant in conjunction with floods of spherical radiolarians at Sites 591, 593 , and 594. The waxing and waning of these radiolarian- $N$. umbonifera faunas were diachronous through latitude and depth; they endured longest at deeper Site 591, and at higher latitudes; disappearing in Zone NN9 at Site 593 and in the late Miocene at Site 594. More diverse radiolarian faunas appeared also at Site 590 during Zone NN6.

The result of this earliest middle Miocene event was the first real compartmentalization of benthics into depthand latitudinally related faunas with different consistent or very abundant species. Only deeper-water faunas at Site 591 contained miliolids and hispido-costate uvigerinids (beginning in Zone NN7). No rectuvigerinids except $R$. spinea penetrated this depth. Faunas dominated by $R$. spinea or $C$. wuellerstorfi alternated with the radiolarian-N. umbonifera faunas through most of the early Miocene (to Zone NN9) at Site 593. Brizalinids, particularly those with reticulate or anastomosing striae, predominated at Site 593 and extended in abundance also to Site 592. The higher-diversity, lower-latitude faunas at Sites 590 and 588 contained large numbers of generalists and cosmopolitan species typical of areas like Car Nicobar (Srinivasan and Sharma, 1980) such as P. bulloides, $S$. lepidula, Melonis barleeanum, Hopkinsina mioindex, Heterolepa kullenbergi, E. bradyi, and the first spinose and hispid uvigerinids such as $U$. proboscidea.

The persistence of these faunas through the early part of the late Miocene was terminated near the Zone 11a/ $11 \mathrm{~b}$ boundary by a second basinwide event involving migration and faunal reorganization rather than evolutionary overturn. Key forms which spread to all sites were the miliolids, such as Pyrgo murrhina, previously found only at the deeper Site 591, and the spinose uvigerinids such as $U$. hispida, which migrated into all sites including Site 594 but were particularly numerous at Site 590 . Site 593 demonstrated the highest specific diversity $(102$ species) and the least faunal disturbance at this time; reticulate brizalinids such as Brizalina finlayi continued to be highly dominant, although the spinose uvigerinids and miliolids did appear in small numbers.

Similar taxa persisted into the latest Miocene (Zone NN12) when radiolarians disappeared from Site 590 and benthic faunal transformations at all sites involved (1) replacement of spinose by spino-costate uvigerinids and the appearance of new species such as $U$. asperula and $U$. hornibrooki; (2) decreased abundance of G. subglobosa and $C$. wuellerstorfi; (3) originations of several new rotaloid species such as Discanomalina semipunctata (see Fig. 2); and (3) continuing abundance of the miliolids, including new species such as Triloculina lucernula and $P$. comata. At Site 593, where faunas were still typified by high abundances of brizalinids, $B$. pusilla became the dominant species of the latest Miocene and the early Pliocene and reticulate brizalinids did not again become abundant at this or any site after this time. The deep-water, more robust variant, $M$. sphaeroides occurred for the first time accompanying $M$. pompilioides at lower bathyal Site 586. Increased dissolution at lower bathyal Site 591 removed a large amount of the fauna just below the Miocene/Pliocene boundary. Dissolution at the middle bathyal depths was less evident, but did produce some diminished faunas at Site 593.

Faunal compositions established in the late Miocene continued through the early Pliocene up to Zone NN14. Diversities ranged from a low of 66 species at the lower bathyal Site 591 to highs of near 85 species at Sites 590 and 593. Although faunas were relatively homogeneous through latitude, higher numbers of agglutinants and heterolepids occurred at Site 590, greater percentages of Hopkinsina mioindex at Site 593, and osangularids were generally more common at lower latitudes (see Figs. 4-7). The genus Ehrenbergina became a more prominent faunal component at all sites. Depth-restricted species increased in numbers at this same time; these included Pullenia quinqueloba, M. pompilioides, Favocassidulina fava, and Globocassidulina arata. Nuttallides umbonifera occurred most consistently at Site 586 , but was present in small numbers in each zone of the early Pliocene at the middle bathyal sites as well.

Faunas at Site 588 contain more genera but the same approximate number of species as the equivalent-depth Site 590, farther to the south. Miliolids are more common, and rectilinear species more frequent than at Site 590. Cibicidids, particularly the turbinate forms which could not be assigned to any species, osangularids in general and $O$. culter in particular, and ornamented brizalinids such as B. pusilla are more frequent at Site 590 .

By comparison with Site 590 , located slightly to the north but at equivalent depths, Site 592 has a greater percentage of miliolids, but fewer osangularids. This site contains the lowest numbers of uvigerinids of any site; the hispido-costate and costate types such as $U$. hornibrooki found commonly at Site 593 do not occur at Site 592.

Faunas are temporarily modified in Zone NN14 by a short-lived influx of large numbers of spinose uvigerinids such as $U$. proboscidea and $U$. hispida at Site 590 and an apparently coeval acme of N. umbonifera at Site 
592. Faunas following this event are similar to those preceding it.

At all sites, faunas above the Zone NN15/NN16 boundary are significantly different from those below. Hispido-costate uvigerinids such as $U$. hispido-costata and $U$. dirupta reach peak frequencies just below the boundary, then spread into all sites regardless of depth or latitude; $U$. dirupta is more common in the lower bathyal sites. Previously uncommon species such as $\mathrm{Ro}$ talia translucens, Cassidulina laevigata carinata, Ehrenbergina pacifica, Bulimina truncana, and $B$. aculeata increase in import along with the osangularids, the stilostomellids, and several agglutinated forms such as $B$. praelonga. Agglutinated species are still more frequent at Site 588 and the buliminids, such as $B$. truncana, at the lower bathyal sites. Bulimina aculeata, however, occurs only at middle bathyal Sites 593 and 594, where improved preservation in the early Pliocene resulted in the first consistent carbonate sedimentary sequences. In the late Pliocene, these in situ carbonate sediments alternate with mixed carbonate and redeposited clays containing outer-shelf benthics such as Trifarina angulosa and $T$. eximia.

Latest Pliocene faunas (Zone NN19-NN20) are transformed by the increased frequencies of the cibicidids at all sites; heterolepids such as Heterolepa kullenbergi and $H$. rugosa are more common at lower latitudes, whereas Cibicides wuellerstorfi and the planulinids predominate at higher middle latitudes and at the lower bathyal sites. After this time, at all Tasman sites except 593, cibicididrich samples containing high proportions of other rotaloid species alternate with faunas rich in uvigerinids and other rectilinear forms. Several unique species occurring only at the higher middle latitude sites include Bolivinita pliozea and Bolivinita sp. at Sites 592 and 594, and B. aculeata at Sites 593 and 594 . In general at this time faunas at Site 593 become more similar to those in the carbonate levels at Site 594 .

\section{BENTHIC FORAMINIFERAL RESPONSE TO OCEANOGRAPHIC CHANGES IN THE TASMAN SEA}

The fact that Tasman Sea benthic foraminiferal faunas differ from north to south at sites located at the same approximate paleodepths indicates the complexity of the interactive processes of biogeographic provincialization, geographic variation, and diachronous alteration of environments which result from the discontinuous distributions of oceanic fronts. Like oceanic fronts, faunas may be in different "states" when subjected to major environmental changes, and faunal response then will not necessarily be uniform oceanwide or even regionally. This notion forms the philosophic basis of the planktonic foraminiferal biostratigraphy in this volume. Its complexity is an accurate reflection of the temporal and spatial heterogeneity of foraminiferal distributions. Only biologic evolution and the oceanic dynamic equivalent should produce coeval and identical faunal developments worldwide.

The extensive descriptions of faunas in this report (Appendices 1-21, Figures 2-7) document the differing "states" of mid- to lower bathyal faunas of the Tasman Sea through latitude and depth. Development of these faunas through the Neogene at Sites 588, 590, 591, 592, and 593 is summarized in Figure 10, using key taxa which demonstrate changes in very high dominance, consistency, rarity, or first and last occurrences.

\section{Monitors of Oceanographic Change}

Three standard monitors of oceanographic conditions have been measured in Tasman Sea sediments. The oxygen isotope record of paleotemperatures and glacial alteration of ocean isotopic composition has been analyzed through the Paleogene at Sites 592 and 593, and the Miocene and Pliocene at Sites 588, 590, and 591 (Murphy and Kennett; Elmstrom and Kennett; Kennett, this volume). The major features at least of the Neogene oxygen isotope record are by now well established (Savin et al., 1981). In the Tasman Sea $\delta^{18} \mathrm{O}$ becomes heavier at the Eocene/Oligocene boundary, in the mid-Oligocene (Zone NP24/NP25), in middle Miocene Zone NN5/NN6, in an excursion near the end of the Miocene (NN11b), at the early/late Pliocene boundary (NN15/NN16), and in the latest Pliocene (NN18) (Fig. 11).

The carbon isotope records, monitors of the oceanic carbon budget, were measured at the same sites. The Tertiary carbon isotope record is less well analyzed and more problematic to interpret (Keigwin and Shackleton, 1980). Tasman Sea records are difficult to interpret because of the species used in the Paleogene and the lack of a planktonic record for the Miocene, so that the surface-to-bottom gradient cannot be estimated. Records at the Eocene/Oligocene boundary differ at Sites 592 and 593. A lightening both at the surface and at depth is found at Site 592, but both values become heavier at Site 593. In the Oligocene there is a slight decrease in the surface-to-bottom gradient caused by heavier values at the bottom, coeval with the positive excursion in oxygen isotope values during the NP24-NP25 zonal interval. The Miocene benthic record includes positive values of $\delta^{13} \mathrm{C}$ coeval with the lightest oxygen isotope values at the beginning of the middle Miocene (Zone NN5). Through the remainder of the Miocene, carbon isotope values become gradually lighter until, near the Zone NN11a/ NN11b boundary, there is a negative excursion at the bottom. The Pliocene record at Site 590 is punctuated in Zone NN14 (about 4.3-4.4 Ma) and in Zone NN19 (about $2.3 \mathrm{Ma}$ ) by increases in the surface-to-bottom gradient caused by lightening both at the surface and at depth, coeval with more positive oxygen isotope values both at the bottom and through the water column.

Sediment accumulation rate records depict the ultimate balance between sediment input and removal at a site. The Tasman Sea records are likely to be representative of original sediment delivery because most sites are located on the upper areas of the Lord Howe Rise, out of the influence of corrosive bottom water and land-derived sediment fluxes. Shipboard seismic records gave no evidence of extensive bottom current activity. If anything, rates may be too low because of the winnowing of fine-fraction nannofossils common at sites on mid-oceanic topographic highs (Shackleton et al., 1984). 


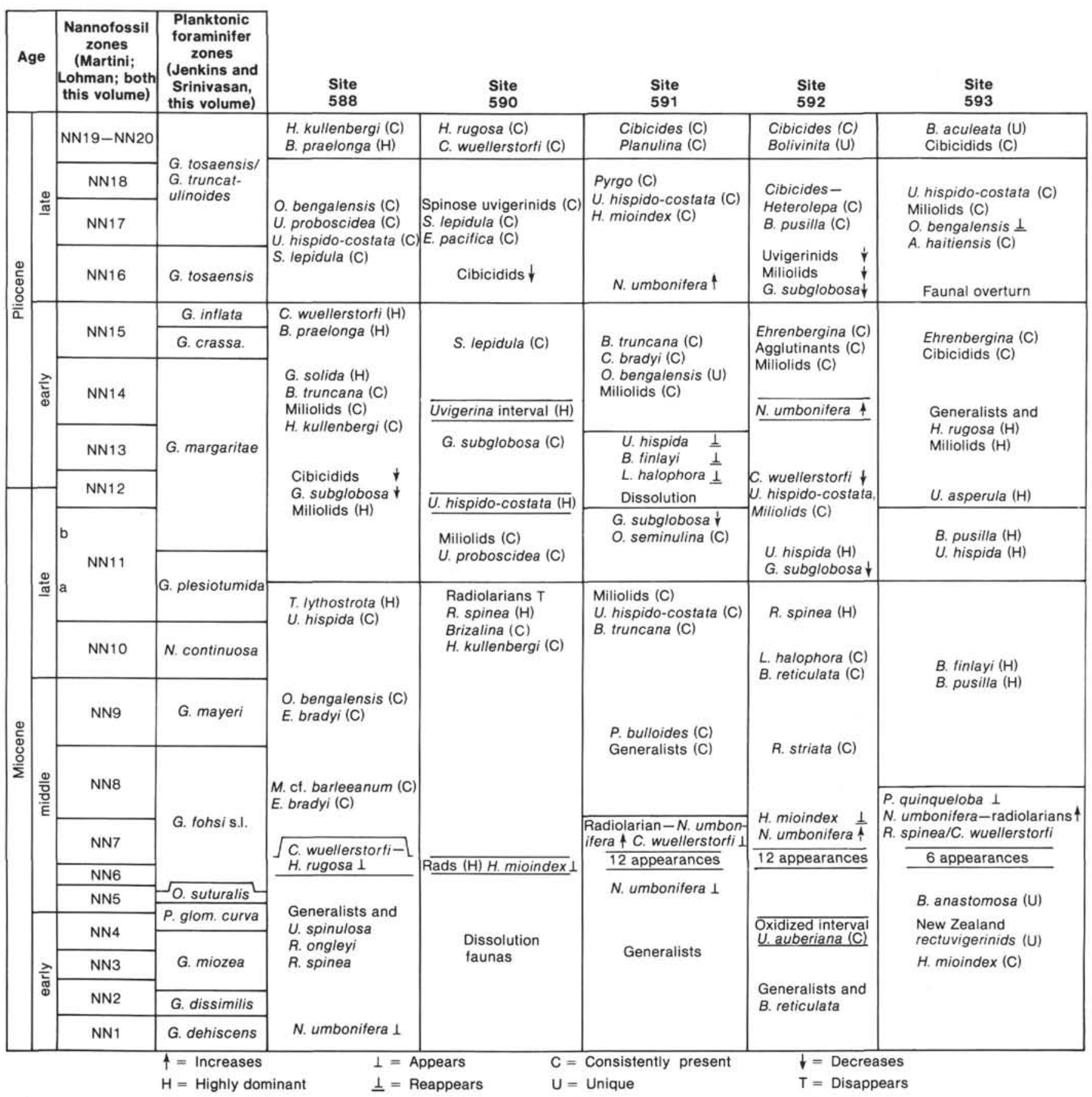

Figure 10. Subdivision of Tasman Sea mid- to lower bathyal sections of the Miocene through Pliocene into intervals with distinctive faunas and/or short, marked faunal-change episodes. Index species for each interval were chosen on the basis of high abundance, endemism to the site at that time, high frequency, or sudden rarity at that site.

The sediment accumulation rate diagram for Site 590 computed aboard ship has been converted to a curve and is plotted in Figure 12. Rates at Site 590 are the highest in the Tasman Sea; nevertheless, the shape of the histogram is typical of the Tasman Sea in general and contains evidence of several basinwide sedimentation events, most of which are attenuated at Site 588, which typically has the lowest accumulation rates $(\sim 2000 \mathrm{~g} /$ $\mathrm{cm}^{2} /$ per m.y.) than the other sites. Episodes of increased rate of sediment accumulation occur during Zones NN6$\mathrm{NN} 9$, increase at the NN11a/NN11b boundary, drop off during Zone NN12, but return to late Miocene highs in the early Pliocene at most sites, and increase to a final high in Zone NN18-NN19.

\section{Benthic Faunas and Sediment Accumulation}

Comparison of foraminiferal fluctuations summarized in Figure 10 and the stable isotope and accumulation rate records indicates a consistent parallelism between sediment accumulation at all sites and their faunal histories. Species evolution, large-scale faunal overturn, and depth migrations all occur synchronously with basin- 


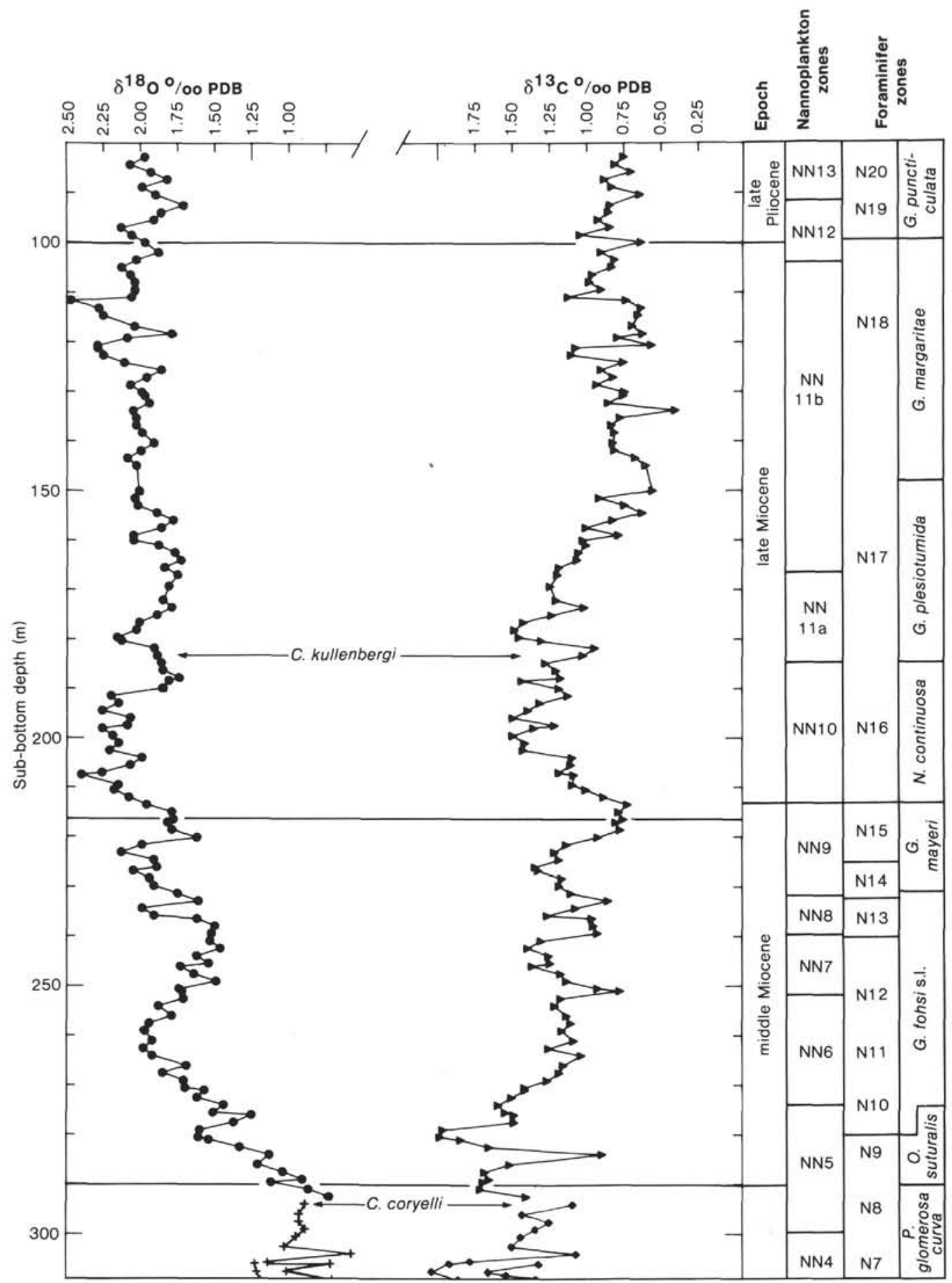

Figure 11 . The $\delta^{18} \mathrm{O}$ and $\delta^{13} \mathrm{C}$ records of benthic foraminifers during the Miocene at Leg 90 Site 588 (from Kennett, this volume).

wide fluctuations in the sediment accumulation rate records, interpreted here to represent fluctuations in surface-water productivity.

Whether by production or preservation, sediment accumulation rates in the Tasman Sea are high (Worsley and Davies, 1979); Tertiary maxima are two to two and one half times greater than at equivalent depths in the southeastern Atlantic Ocean (Shackleton et al., 1984). Benthic faunas are more diverse and have higher numbers of specimens per sample at these sites with high sedimentation rates than in other oceanic areas (Boersma, 1984b).

The idea that increased rates of sediment accumulation indicate increased sediment supply generated by surface-water productivity is supported by the carbon isotopic record of the early Pliocene (Elmstrom and Kennett, this volume). Increased biotic production at the surface is usually represented in the carbon isotopic record in one of two ways. Oceanwide productivity events associated with reorganization of oceanic carbon cycling 
A. BOERSMA

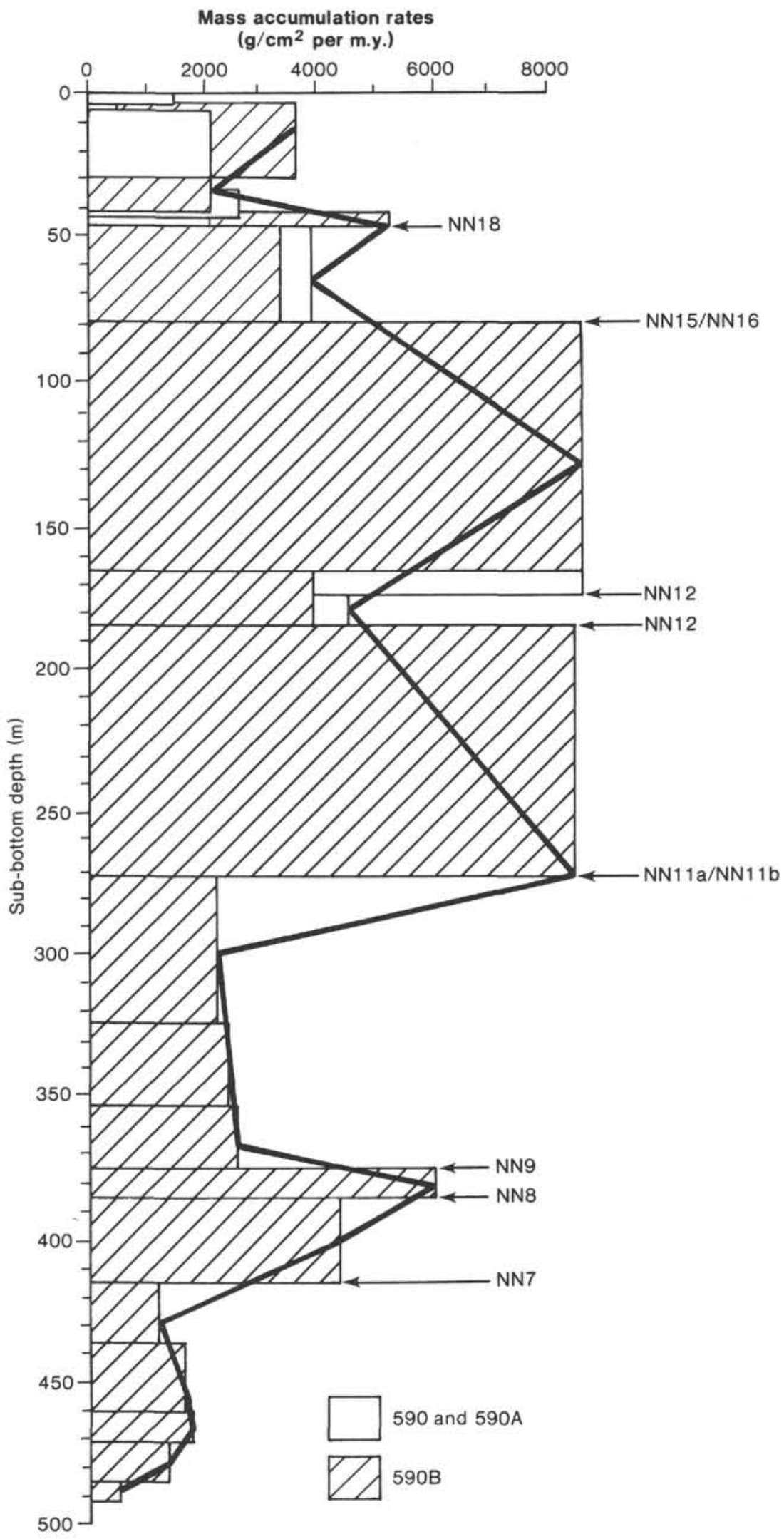

Figure 12. The record of sediment accumulation rates plotted with the combined frequencies of all Uvigerina species in each zone through the Miocene and Pliocene at Site 590. Frequencies are normalized to the number of samples examined in each zone. Rates were calculated using the nannofossil biostratigraphy of Martini; Lohman; both this volume. Nannofossil zonal age of each major shift in the record is indicated to the right of the diagram. 
are reflected by an increase in the surface-to-bottom gradient involving more positive values both at the surface and at depth. Light carbon is being stored in biologic systems, and not recycled. Heavy values at the bottom are the ocean-atmosphere response to this situation. By contrast, heightened productivity resulting from local upwelling is evidenced by light carbon values at the surface and at depth, which indicate that light carbon is being recycled; more positive oxygen isotope values among the planktonics demonstrate that cooler temperatures are being distributed higher in the water column (Prell and Curry, 1981). The early Pliocene stable isotope records at Site 590 exemplify this scenario in Zone NN14 and suggest heightened surface-water productivity in a local upwelling correlative with high rates of sediment accumulation (see Fig. 12). Figure 10 shows the Uvigerina maximum which is coeval with this upwelling event.

A further indication of episodes of high surface-water productivity over the Lord Howe Rise is provided by the radiolarians (see Appendices 1-21 for presence-absence data). Large numbers of nearly monospecific spherical radiolarian assemblages first appear in coarse-fraction residues at the beginning of the middle Miocene at Sites 591 and 593 and persist through Zone NN9. They appear slightly later at Site 590, where they are common throughout the middle Miocene, and disappear in the late Miocene near the NN11a/NN11b boundary. Radiolarians occur sporadically at the Miocene/Pliocene boundary and throughout the Pliocene, most commonly at Site 590, but never in great abundance. These radiolarian occurrences suggest the migration of high-productivity surface currents into the areas of Sites 591 and 593, both of which lie near the Tasman eastern boundary current system, and at Site 590, which lies within the path of a subtropical divergence, called the Tasman Front. Their absence at Site 592 indicates a pronounced frontal zone between Sites 592 and 593; the foraminiferal faunas shown in Figure 10 corroborate this.

Radiolarians disappear from Site 590 near the Zone NN11a/NN11b boundary (about $10 \mathrm{Ma}$ ), coeval with the major increase in sediment accumulation rates there and throughout the Tasman Sea (Fig. 11). This Tasman event corresponds in time with the heightened productivity episode in the Pacific during the late Miocene from 10-5 Ma, when silica production increased in high northern latitudes (Woodruff and Savin, in press) and in the western equatorial Pacific (Leinen, 1979), but decreased dramatically in the southwestern sector. If productivity is not reflected in abundance of siliceous organisms, then another source must be postulated. In the early Pliocene, high rates of sediment accumulation in the Tasman area have been attributed to increased productivity of nannofossils (Elmstrom and Kennett, this volume). This may have been the case also in the late Miocene, with or without enhanced conditions for carbonate preservation. However, increasing productivity is also likely, in Pacific intermediate waters, to cause an expansion of the oxygen minimum zone (Woodruff and Douglas, 1981), which then acts to preserve carbonate and residual organic matter by decreasing oxidation and $\mathrm{CO}_{2}$ release to sediment. Furthermore, this residual organic matter should support a greater biomass at the bottom.

The very high rates of sediment accumulation despite the absence of radiolarians, the benthic carbon isotope lightening in the late Miocene records at Sites 588, 590, and 591, the high late Miocene diversities of benthic foraminifers, and the high Benthic Numbers in general in the Tasman Sea all suggest that there was a productivity increase in the Tasman Sea coeval with the high-productivity episode in the Pacific from 10-5 Ma, and that enhanced preservation of organic matter supported the large foraminiferal faunas.

Further support for a direct relation among increased surface-water productivity, sediment accumulation, and benthic faunal composition can be drawn from the foraminiferal species themselves. One of the most unique features of these benthic faunas is the large numbers and high frequencies of uvigerinids, including the diverse and occasionally endemic species of Rectuvigerina. Several lines of evidence demonstrate a relationship between uvigerinids and high surface-water productivity and/or high rates of sediment accumulation. Lutze (1979) included uvigerinids among his "cool" group which predominated in Meteor cores off West Africa during higher-productivity glacial episodes. In Recent sediments taken in Meteor cores in the same area, the uvigerinids and rectuvigerinids correlated with areas of highest organic carbon resulting from high surface-water productivity (Lutze and Coubourn, 1983). This relationship is previewed by the first consistent appearance of uvigerinids in the open ocean during the high-productivity episode of the late Paleocene (Boersma, 1984a) that involved oceanwide increases in sedimentation rates (Worsley and Davies, 1979). It is reiterated by the first diversification of the rectuvigerinids during the episode of high sedimentation rates in the late Oligocene to early Miocene (Worsley and Davies, 1979). And at Quaternary glacial/ interglacial boundaries it is most visible in the disappearance of uvigerinids from most open ocean sites, particularly in high-productivity areas such as the Panama Basin-a disappearance correlated with the decrease or disappearance of siliceous fossils.

The relationship of uvigerinids to high rates of sediment accumulation and heightened surface-water productivity in the Tasman Sea is corroborated by their involvement in almost every major faunal reorganization coeval with sedimentation rate changes (Figs. 10, 12), their evolutionary diversification during the first episode of high sedimentation rates in the middle Miocene (Fig. 3 ), their great abundance and frequency at Site 590, where sediment accumulation rates are highest, and their abundance peak at Site 590 during the upwelling episode in Zone NN14.

To test this relationship, uvigerinid frequencies through the Neogene are plotted against the curve of sediment accumulation for Site 590 (Fig. 12). These curves have several drawbacks: (1) frequency per zone is not the best monitor of the uvigerinids; an abundance peak such as that in Zone NN14 is lost; (2) uvigerinid frequencies are averaged over a whole zone; and (3) spacing of sample 
points on the two curves is not the same. Nevertheless, there is good correspondence between the curves of uvigerinid frequency and rates of sediment accumulation at Site 590. Slight offsets between the two curves are attributable to sample point offset.

\section{Faunas and Glacial Events}

Several glacial events of differing magnitude and duration are represented in the stable isotope records from the Tasman Sea (Kennett, this volume). These include the short-lived event coeval in this area with the Eocene/ Oligocene boundary, $\sim 36.5 \mathrm{Ma}$; (Mathews and Poore, 1983, have demonstrated that this glacial actually occured in the earliest Oligocene elsewhere); the development of Antarctic glaciation in the early middle Miocene, $\sim 14 \mathrm{Ma}$ (Shackleton and Kennett, 1975); the further glacial buildups just below the Miocene/Pliocene boundary, $\sim 5 \mathrm{Ma}$ (Savin et al., 1981) and in the midPliocene, 3.2 Ma (Shackleton and others, 1984a; Prell, 1982); and the development of Northern Hemisphere glaciation, $\sim 2.5 \mathrm{Ma}$ (Backman, 1979). Glacials correspond with periods of high sediment accumulation in the Tasman Sea in the middle Miocene and the latest Pliocene, but not at the Eocene/Oligocene, Miocene/Pliocene, or early/late Pliocene boundaries. Rates of sediment accumulation actually plummet in the latter two instances, and are generally low in the early Oligocene.

Three glacially correlated faunal patterns which first develop during the Eocene/Oligocene boundary event and recur with each later glacial are (1) the covariance of uvigerinids with signals of heightened productivity, in this case a pulse of radiolarians and carbon isotopic evidence of upwelling at mid-bathyal Site 592; (2) migration toward shallower depths of lower bathyal species, which at this time involved the first appearance of Nuttallides umbonifera at mid-bathyal Site 593; and (3) disappearance of large specimens of Globocassidulina subglobosa above the boundary and their replacement by low-diversity faunas containing cosmopolitan and austral species.

The appearance of $N$. umbonifera at middle bathyal sites is anomalous and suggests unusual oceanographic conditions. Evidence on the ecology of $N$. umbonifera comes from several sources. In the Quaternary abundances of this species frequently parallel the path of Antarctic Bottom Water (AABW), but correlate with a strongly corrosive bottom environment and carbonate undersaturation in areas not overlain by AABW (Lohman, 1978; Bremer and Lohman, 1982). In the Neogene, $N$. umbonifera reaches high percentages in abyssal sites located at over $3000 \mathrm{~m}$ water depth in both the Atlantic and Pacific oceans. It occurs in middle bathyal areas in very low numbers, if at all, and in discrete pulses (Woodruff, 1979; Tjalsma, 1983). In the Paleogene, N. umbonifera first appears in lower bathyal and abyssal areas where sedimentologic and isotopic evidence demonstrate the first development of cooled, corrosive and/or low oxygen conditions at the bottom (Tjalsma and Lohman, 1983; Boersma, 1985). It occurs at middle bathyal depths only during short episodes of dissolution just above the Eocene/Oligocene boundary (Boersma, in press) and in the mid Oligocene (Boersma, 1985). In most cases it varies inversely with the miliolids and uvigerinids. Together these studies suggest that in the Tertiary, as well as the Quaternary, it is justifiable to use the presence of $N$. umbonifera to trace corrosive conditions and, where dissolution is not prominent, cooled and well-oxygenated conditions. Therefore the presence of $N$. umbonifera at Site 593 is interpreted to represent the glacially forced, short-lived penetration into shallower depths of cooled, "new" waters and related conditions at the bottom at the Eocene/Oligocene boundary.

Eutrophication of Tasman Sea current systems, indicated by a large influx of radiolarians at Sites 590,591 , and 593 (Fig. 10) as well as in New Zealand land sections (Hornibrook, 1971) occurred during the middle Miocene glaciation that is recognized worldwide in stable isotope records (Shackleton and Kennett, 1975; Savin et al., 1981). This glacial can be traced in the Tasman Sea by (1) increased rates of sediment accumulation (Fig. 12) beginning in Zone NN6 and persisting through most of the middle Miocene at Sites 591 and 593 and (2) the characteristic heavy benthic isotope values (Kennett, this volume). Several faunal patterns reiterate those of the Eocene/Oligocene glacial, with important differences and additions: (1) the faunal changes are long-lived, not episodic; (2) during the sediment accumulation increase miliolids first appear, followed later by an influx of spinocostate uvigerinids at lower bathyal depths; (3) updepth migration of $N$. umbonifera into middle bathyal Sites 593 and 594 accompanies very large, monospecific, radiolarian faunas and intense dissolution at Site 594; (4) at Sites 591 and 593 cibicidid-rich faunas alternate with uvigerinid-bearing samples, previewing a pattern which will occur in all later glacials and will eventually occur throughout depth; and (5) radiolarians first commonly appear at Site 590, located at lower middle latitudes under the Tasman Front, coevally with the first appearance of striate hopkinsinids and rectuvigerinids.

Based on the acknowledged relationship between uvigerinids and high organic carbon in sediments, the high sediment accumulation rates, and the expansion of radiolarians through the Tasman Sea, I conclude that the middle Miocene glacial period brought invigorated oceanic circulation, increased rates of upwelling, and heightened productivity in divergence zones, under the Tasman Current system both within the Tasman Sea in the area of Site 593 and on the Chatham Rise, as well as at higher middle latitudes in the eastern boundary current system. Because the Antarctic was transformed from an oligotrophic to a eutrophic region at this same time (Schnitker, 1980), it is probable that Antarctic-derived waters feeding this circulation were themselves more nutrient-rich. Schnitker (1980) has suggested that eutrophication of the Antarctic and invigorated circulation resulted from the increased production of North Atlantic Deep Water (NADW), which disrupted stratification of Antarctic water masses, allowing upwelling of more nutrient-rich underwaters. Along similar lines Blanc and Duplessy (1982) determined a single, southern source of deep water to the Pacific (probably a type of NADW) beginning in the middle Miocene. It appears that eu- 
trophication of the Antarctic, high fertility of the southern Pacific, and compartmentalization of nutrients in the Pacific all occurred during this same glacial episode and are reflected in the benthic faunas.

The glacial episode at the termination of the Miocene is signalled by heavy oxygen isotope values at Sites 588 and 590 (Kennett, this volume) but decreased sediment accumulation rates at most sites. Dissolution, which may have contributed to the low accumulation rates, was intense at lower bathyal sites, but only moderate at middle bathyal depths. At this time (Fig. 10), miliolids and uvigerinids became highly dominant at middle bathyal sites, miliolids disappeared from lower bathyal Site 591, spinocostate replaced spinose uvigerinids, uvigerinids developed at the expense of Cibicides wuellerstorfi and $G$. subglobosa, and the lower bathyal species, Melonis pompilioides and Pullenia quinqueloba, migrated updepth into the middle bathyal zone, whereas $N$. umbonifera remained important only at lower bathyal sites. These were temporary changes, and faunas typical of the later Miocene returned in the early Pliocene.

Interpretation of the faunal patterns of this glacial is based on the relation between uvigerinids and high organic carbon content; the usual restriction of spinocostate uvigerinids to deeper, cooler sites; and the inverse correlation between miliolid abundance and N. umbonifera and carbonate undersaturation (Bremer and Lohman, 1982). These patterns suggest that whereas lower bathyal depths became more corrosive to carbonate, sediment at middle bathyal depth was relatively well preserved and waters were well saturated with respect to calcium carbonate. This may reflect penetration of the lysocline into shallower depths. However, cooler water conditions typical of the lower bathyal zone moved updepth into the middle bathyal zone at this time. The spino-costate uvigerinids which now dominated at middle bathyal depths originally inhabited the cooler, slightly less organic carbon rich lower bathyal zone. In other words, these was slightly lower nutrient availability at cooler temperatures at shallower depths.

This glacial event is coeval with the termination of the High-productivity Episode (10-5 Ma) in the Pacific, and the lower sediment accumulation rates in Tasman Sea sites conform to this pattern. The decreased abundance of $C$. wuellerstorf $i$ and other cibicidids may lend evidence which explains this decrease in sediment accumulation. In the Holocene, cibicidids, particularly $C$. wuellerstorfi, are associated with high-productivity regions receiving large amounts of hemipelagic material. Under the West African upwelling during the Holocene, the abundance of $C$. wuellerstorf $i$ is correlated with high accumulation rates of terrestrial organic carbon, not marine organic carbon, which is correlated with higher numbers of uvigerinids (Lutze and Coubourn, 1983). It is suggested, therefore, that both the lower productivity and the major decrease in cibicidids in the latest Miocene reflect the decreased input of carbon to the ocean from terrestrial sources

The glacial buildup near the NN15/NN16 boundary is accompanied by plummeting rates of sediment accumulation at all sites. Uvigerinids increase to a mid-Plio- cene high coeval with the peak in sediment accumulation (Fig. 12), but decrease dramatically and become more geographically compartmentalized in Zone NN16; spinose forms are concentrated in the lower latitudes, spino-costate taxa in the higher middle latitudes and at lower bathyal depths. The miliolids also decrease generally across the boundary into Zone NN16. By contrast with the previous glacial buildup, however, cibicidids expand and new genera such as Osangularia, Rotalia, and Cassidulina are more commonly found in the faunas. Expansion of the cibicids may indicate the persistent presence of terrestrial organic matter. These faunal events represent the transition into a fully glacial pattern. Lack of miliolids and uvigerinids suggests the lowered productivity which the sediment accumulation rates corroborate. The less intense benthic oxygen isotope signal (Kennett and Elmstrom, this volume), lack of upwelling signals, and the restriction of $N$. umbonifera to middle bathyal depths at Site 591 and (in greater abundance) Site 586, suggest mild restratification and the development of different intermediate and deep-water types and related conditions at the bottom in the Tasman Sea after this time.

The final Pliocene glaciation, about $2.5 \mathrm{Ma}$, is reflected in (1) a peak in sediment accumulation rates; (2) a positive excursion in the oxygen isotopes; (3) proliferation of the cibicidids, which alternate with uvigerinidbearing samples, indicating the initiation of permanent glacial-interglacial faunal patterns and oceanographic conditions at this time.

\section{SUMMARY}

The unique compositions of Tertiary-age middle to lower bathyal benthic foraminiferal faunas are largely modulated by (1) fluctuations in oceanic surface productivity developed in several oceanographic fronts which migrate through the Tasman Sea and (2) glacially forced vertical displacements in hydrochemical boundaries. Heightened productivity during the numerous steps in glacial buildup, from the latest Eocene to the latest Pliocene or during the late Miocene high-productivity episode in the Pacific, is reflected in the very high rates of sediment accumulation in the Tasman Sea. Evolutionary overturn, all major faunal reorganization, and depth migrations are coeval with the large-scale features of the sediment accumulation rate curves for the Tasman Sea sites.

Faunal overturn reflecting high productivity and expansion of the oxygen-minimum zone involves the uvigerinids and miliolids. Uvigerinid frequencies vary directly with the the large-scale features in the sediment accumulation rate records, and uvigerinids reach peak abundance during local upwelling events. Glacial fluctuations involving heightened productivity are expressed by alternating cibicid-rich and uvigerinid-bearing samples.

Lower bathyal faunal elements migrated to shallower, mid-bathyal sites during glacial episodes; overturn which causes shallowing of oxygen-rich, corrosive, and cool bottom waters is indicated by high abundances of Nuttallides umbonifera at middle bathyal sites. Shallowing 
of deep-water, less corrosive conditions in the latest Miocene glacial resulted in migration into shallower depths of Melonis pompilioides, Pullenia quinqueloba, and spino-costate uvigerinids, high dominance of miliolids, and minimal dissolution at middle bathyal depths.

\section{ANNOTATED LIST OF SELECTED SPECIES}

The following list is not inclusive, but contains species for which information exists on taxonomy and morphotypic variation. A new species is described and is figured in Plate 17.

Anomalinoides globulosa (Chapman and Parr). Plate 2, Figs. 1-3. This species varies markedly in thickness and in the eccentricity of the final chamber. Specimens closely resemble Anomalinoides badensis (d'Orbigny), first described from the Vienna Basin (d'Orbigny, 1846). Specimens from higher latitudes tend to have squarer, less inflated chambers and a more lobulate periphery. Ranges from early Miocene through the Pliocene.

Anomalinoides orbiculus (Stache). First named from New Zealand, this species is relatively common in the Paleogene levels of Site 592 and 593. Specimens from the higher-latitude Site 593 are rounder and resemble Anomalinoides ammonoides (Reuss). At Site 592, this species is squarer, thinner, the periphery is more angled and the umbilical flaps are more articulated.

Anomalinoides semicribrata (Beckman). Plate 1, Figs. 1-6. This species possesses a peripheral aperture which extends slightly onto the spiral side. The umbilical side is not umbilicate and both sides lack umbonal knobs; nevertheless it is closer to the genus Anomalinoides than Gavelinella, to which it was later assigned. This species usually has 4 to 5 chambers in the final whorl; more tightly coiled forms with the larger chamber number are typical at Site 593 during the Paleogene. At Site 592 all degrees of coiling tightness are present. In the early Miocene, specimens at Site 593 are much larger and more evolute, and the chambers are less inflated than in lower latitudes (Hole 588C). Comparison of late Miocene forms at Site 590 with the deeper-water Site 591 demonstrates that the deeperdwelling specimens are smaller and dextrally coiled, whereas the coiling of those at Site 590 is sinistral. Toward lower latitudes the numbers of pores decrease, but they become larger in size (Plate 1, Figs. 4-6).

Bolivinopsis praelonga (Schwager). Plate 3, Figs. 3-4. As figured by Srinivasan and Sharma (1980), this species is both large and especially long. Comparison of specimens which would be called Bolivinopsis cubensis in the Paleogene (Plate 3, Figs. 1,2) demonstrates that the two species are identical except for the larger size and longer biserial portion on $B$. praelonga. Elongation is a common feature of the evolution of long-lived rectilinear benthic species; most of them receive different names when they have added more chambers. In the case of Bolivinopsis, the addition of more chambers does not involve a change in coiling, which would be sufficient reason to use a different species name. Therefore the species cubensis should probably be referred to the level of forma of the species praelonga.

Brizalina finlayi (Hornibrook). Plate 4, Figs. 3-4. This species has ornament which is intermediate between that on Brizalina pusilla and $B$. reticulata. It is generally smaller and more delicate than those two species. In the early Miocene individuals at higher latitudes are generally larger, have more pointed initial ends, and are longer. Their costae are more wavy and finer than those at low-latitude Site 588.

Brizalina pusilla (Schwager). Plate 4, Figs. 1-2. As is the case with many other long-lived bathyal benthics, there appear to be two names, one applied in the Paleogene and the other in the Neogene. In this case one Paleogene name is B. tectiformis (Beckman). Comparison of populations from the Atlantic province and from Barbados, where it was named (Beckman, 1953), indicate that $B$. tectiformis is almost identical with $B$. pusilla from the Tasman Sea and from Car Nicobar. Boltovskoy (1978) pictures Indian Ocean populations of this species which are identical to those from the Tasman Sea.

Brizalina reticulata (Hantken). Plate 4, Fig. 5. This species occurs worldwide during the Oligocene and Miocene. Although some authors believe that it is conspecific with Brizalina anastomosa (Finlay), there is a clear distinction between the two in the Tasman Sea.
Brizalina anastomosa is the more common form at Site 593, where it is shorter, broader, and has more strongly developed ornament. Bulimina aculeata d'Orbigny. Plate 5, Fig. 1. This species is not common in the Tasman Sea, but is very frequent at Site 594 on the Chatham Rise in hemipelagic sediments containing large amounts of siliceous fossils. At higher latitudes the spines of this species are blunter and much shorter.

Bulimina striata d'Orbigny. Specimens from the Tasman Sea are identical with forms from the Miocene of the Vienna Basin and from the Atlantic province. There seems no good reason to use Cushman's taxon, B. striata mexicana.

Bulimina truncana Guembel. Plate 5, Figs. 2-5. This species varies greatly both through latitude and depth. This variability is expressed in the number of costae, their height, their orientation relative to the test axis, and the number of smooth chambers at the apertural end. Such variability has resulted in a large number of names in the literature: small, inflated forms with few costae which begin almost at the aperture have been called $B$. rostrata Brady; forms with numerous, slightly wavy costae which begin on the third chamber are usually called B. alazanensis Nuttall (Plate 2, Fig. 7); when the costae anastomose, the name is Bulimina consanguinea Sequenza. Bulimina truncana is very similar to $B$. alazanensis, except the costae are slightly fewer in number, more bladelike and straight, and begin on the first or second chamber (rather than the third, as on $B$. alazanensis or $B$. consanguinea). Because both types occur in populations from the Tasman Sea, the older taxon, B. truncana, has been used.

There are two main latitudinal trends: lower-latitude forms are much larger and have fewer costae which usually begin on the first or second chamber, but more frequently on the first chamber. With increasing depth, costae become more numerous and more narrow, and individuals are generally smaller. Forms with a few anastomosing costae occur only at Site 593 in the early Miocene and have been called $B$. consanguinea.

Cibicides wuellerstorfi (Schwager). This is a common and well-known species which is cosmopolitan at bathyal to abyssal depths. Following Srinivasan and Sharma (1980), inter alia, it is placed in the genus Cibicides because of its sharp apertural face and the peripheral aperture which continues onto the spiral side. In the Tasman Sea this species is most common during the middle Miocene. During the middle Miocene, intergrodes between $C$. wuellerstorfi, $H$. kullenbergi, and $H$. rugosa occur in several samples. This is especially true of samples in the Globorotalia fohsi Zone, where morphotypes of $H$. rugosa are very flat and less porous. It is larger at lower latitudes in both the shallower and deeper Sites 588 and 586. There is marked variation in the porosity of this species; lower-latitude forms seem to have fewer pores in the middle Miocene. At the very end of the Miocene, during the miliolid-uvigerinid acme intervals, it becomes much less porous, along with the other rotaloid species. This demonstrates that there is more than a latitudinal pattern to its porosity.

Cibicidoides parki (Finlay). Plate 7, Figs. 1-5; Plate 8, Figs. 1-5. This is a well-known index species in New Zealand sections. It has been identified in the Possagno section of Italy and in the American Gulf Coast where it has been called Cibicidoides cancelata (Cushman), which name is actually older. However, it appears that this species was first named Cibicides truncanus (Guembel) in the Monte Brione section of Italy. Because this synonomy could not be confirmed by the samples I have from this section, the local taxon, $C$. parki, has temporarily been retained for the lower-spired, less strongly ornamented forms from the Tasman Sea.

Suggestions that this species should be referred to the genus, Osangularia, seem unwarranted because of the distinctive cibicidid aperture seen on Plates 7-8, as compared with that on $O$. culter in Plate 12, Figs. 4-6.

Cibicidoides f. ungerianus (d'Orbigny). Several intermediate-depth sites of the Pacific and the Atlantic contain a cibicidid which closely resembles $C$. ungerianus from the Vienna Basin. Comparison of specimens from the Tasman Sea and Viennese material has shown that the Tasman forms are very similar, but larger, similarly flat, have a similarly pinched periphery and keel, possess the same number of slightly depressed, curved sutures, but lack the ornamented or limbate spiral and the slight umbilical fosse on the ventral side. This is probably a deep-water ecophenotype of $C$. ungerianus. Because of its widespread distribution in oceanic sites, the 
species should be in some of the older literature, but I have yet to find it.

Discanomalina semipunctata (Bailey). Plate 2, Figs. 4-6. Originally this species was classed as an Anomalina, but the character of the umbilical side, the peripheral aperture, and the partially evolute dorsal side all locate it in the newer genus, Discanomalina. It has been suggested that this species is one generation of the attached, shallow-water genus Carpentaria, but the interpretation is difficult to accept in view of the distribution and frequency of this species at middle and lower bathyal depths in the Tasman Sea.

Ehrenbergina pacifica Cushman. Of the several species of Ehrenbergi$n a$ present in the Tasman Sea, only $E$. pacifica is present at all sites by the Pliocene. There are definite latitudinal gradients both in the degree of spinosity and in the number of chambers in the adult. At higher latitudes specimens are more spinose and are usually shorter and broader, adding fewer chambers which enlarge more rapidly. In general, the ehrenberginids of the Tasman Sea are less angular and more rounded, almost bulbous, like $E$. marwicki Finlay in Plate 11, Figs. 1-2.

Globocassidulina subglobosa (Brady) This well-known, cosmopolitan species occurs consistently but not in abundance at most of the Tasman Sea Sites. The one exception is in the late Eocene at Site 593 , when $G$. subglobosa is both very common and very large. Such large specimens do not again occur in the Tasman Sea.

Hanzawaia cushmani. This species becomes much higher-spired at Site 592 than at Site 593. It has been placed in synonomy with $\mathrm{H}$. ammophila (Guembel), as repictured by Hagn (1956). However, comparison of material from Monte Brione indicates that $H$. ammophila is a much smaller, flatter species with many more chambers in the final whorl, thicker sutures, and a much less domed shape than Tasman forms.

Heterolepa kullenbergi (Phleger and Parker). The species is placed in the genus Heterolepa because it is plano-convex to slightly biconvex, but not biumbonate, and possesses an aperture which is not only peripheral with a lip, but extends onto the umbilical side as well as onto the spiral side. The apertural features are those of a Heterolepa, not a Cibicidoides.

There is marked variation in the roundness of the test and the spire height, but no latitudinal or depth-related pattern could be inferred. Populations are, however, much larger at the deeper Site 591 than in the shallower sites. The species appears to be a solution-resistant form in both carbonate and siliceous facies.

It first appears during the $G$. angulisuturalis Zone at Site 588, apparently evolving from an ancestral form which was smaller, chunkier, and possessed a distinct keel.

Heterolepa rugosa (Phleger and Parker). This species varies geographically in the development of its porosity, the degree of reticulation and spiral limbation, and in the spiral height. Oldest populations demonstrate pores on only one-half of the chambers in the final whorl. Reticulation is barely developed and the walls appear coarse on only about half of the chambers. After its expansion in the Globorotalia fohsi Zone, the species shows definite gradients; lowerlatitude forms are flatter and more ornamented. Such forms appear to grade into $C$. wuellerstorfi and $H$. kullenbergi. Reticulations, well developed at Site 590, are reduced to a coarsening of the wall texture at Sites 592 and 593 . None of the specimens from the Tasman Sea, however, show the same degree of reticulation as typical forms from the Atlantic. Whereas those at the deeper Site 591 are larger than their counterparts at the shallower Site 590, they also lack well-developed reticulation or pronounced spiral limbation.

Hopkinsina mioindex Finlay. The species is more or less angular from site to site, but demonstrates marked variation in the development of the striae. Striae are always fewer and finer at Site 594. At Site 591 striae are higher and somewhat less numerous than on individuals from shallower-water Site 590. There is a consistent trend for this species to become longer, thinner, and to possess many fine costae toward higher latitudes in the shallow Tasman Sea sites. Lower-latitude forms are consistently shorter, wider, and have fewer biserial chambers.

Laticarinina halophora (Stache). This species is commonly called Laticarinina pauperata (Parker et al., 1865), although Brady indicated that Stache's species, named in 1864, was identical (Barker, 1960). The older taxon, $L$. halophora, is therefore retained here. It is easily differentiated from $L$. bullbrooki and $L$. altocamerata, both of which occur frequently in Tasman Sea sections, by its much larger number of chambers, which are barely convex above the plane of the wide-flanging keel.

Marginulinopsis hochstetteri (Finlay). This very large and distinctive species is an index for the Bortonian of New Zealand (Hornibrook, 1971); it occurs into the Oligocene in the Tasman Sea at both Sites 592 and 593. At the latter site individuals are much larger, spines are much more numerous and acute, and even the periphery is serrate to spiny.

Melonis cf. barleeanum (Williamson). This form is distinguished from typical specimens by being much flatter and slightly less porous. It is more common in the Tasman Sea than typical $M$. barleeanum, particularly earlier in the species' ranges.

Melonis pompilioides (d'Orbigny). Typical specimens of this species occur in the Tasman Sea primarily at the two deeper Sites 591 and 586 , where $M$. sphaeroides is also found briefly. The species occurs in pulses in the shallower sites, where it is distinctly smaller and very slightly thinner than the deeper-water indigenes. A second difference is found in the degree of chamber inflation; at Sites 588 and 590 the earlier chambers are less inflated than the final ones. At Site 591, chamber inflation is relatively constant throughout the final whorl. At middle bathyal depths there is a tendency for size to decrease at progressively lower latitudes.

Nuttallides umbonifera (Cushman). This species is not common in the Tasman Sea except in discrete pulses in the early to middle Miocene, when it occurs in very large numbers in coarse fractions consisting largely of spherical radiolarians. These pulses seem to be coeval between Sites 591, 593 in the Tasman Sea, and Site 594 on Chatham Rise, where $N$. umbonifera may be the only species in the entire sample. The radiolarian- $N$. umbonifera pulses continue at Site 594 through the middle and into the later Miocene. Nuttallides umbonifera is consistently larger at the higher-latitude sites, and always larger at Site 594 than elsewhere.

Osangularia bengalensis (Schwager). This demonstrates definite latitudinal and depth-related gradients which persist through the Miocene and Pliocene. It is more frequent in the deeper Site 591 than in the equatorial, deep Site 586. In the shallower-water sites there is a marked gradient in its abundance; it is more common toward lower latitudes.

Osangularia culter (Parker and Jones). Plate 12, Figs. 4-6. Like $O$. bengalensis, this species demonstrates latitudinal and depth-related frequency gradients; they are the inverse of those of $O$. bengalensis. Osangularia culter is more common at deeper-water Site 586 than at Site 591; it is more frequent at the sites toward higher than toward lower latitudes. However, the genus Osangularia is consistently less common at higher latitudes and is absent altogether at Site 594 in the Pliocene.

Pullenia quinqueloba d'Orbigny. Like $M$. pompilioides, this species shows a preference for the deeper sites. It occurs in discrete pulses in shallower sites.

Rectuvigerina ongleyi (Finlay). Plate 17, Fig. 2. This species is an index for the late Oligocene into early Miocene in New Zealand. In the Tasman Sea it ranges through the middle and late Miocene; in the early Miocene, only its predecessor, Uvigerina spinulosa, is present. That is to say, specimens of this group do not begin to add uniserial chambers in Tasman Sea sites until middle Miocene Zone NN6. It occurs at all of the shallower Tasman sites, but is not found at the deeper Site 591 . More spinose morphotypes are found at Site 593 in the later Miocene.

Rectuvigerina postprandia (Finlay). Plate 17, Fig. 6. In New Zealand sections this species is an index for the late Eocene into early Oligocene (Hornibrook, 1971), and is restricted to this same interval in the Tasman Sea. In the Atlantic, however, it occurs later in the Oligocene (Boersma, 1984b).

Rectuvigerina prisca (Finlay). Plate 17, Figs. 1, 7. Although in New Zealand this species is an index for the late Eocene (Hornibrook, 1971), it occurs from the late Eocene through the Oligocene in the Tasman Sea. In older populations, individuals add only one or two uniserial chambers. In the late Oligocene, however, many specimens possess 2-4 uniserially added chambers. Striae are attenuated on these uniserial chambers (Plate 17, Fig. 1).

Rectuvigerina spinea (Bermudez). Plate 18, Fig. 5. These very spinose rectuvigerinids are the only ones to appear in the deeper-water sites; other groups are restricted to the shallower parts of the Tasman Sea and New Zealand land sections. Individuals from the deeper Site 591 are more strongly striate and very much more spinose than 
those at the shallower Site 590. Upper bathyal morphotypes with very few spines have been called Siphogenerina opima Cushman, which species should probably be referred to the genus, Rectuvigerina.

Rectuvigerina striata (Schwager). Plate 17, Fig. 5. This unique species is characterized by its very lobulate periphery resulting from the almost spherical shape of the uniserially added chambers. Irregular, occasionally anastomosing costae are usually present on several chambers. It is differentiated from the similar Rectuvigerina striatissima (Stache), which also occurs in the Tasman Sea, by the fact that the striations on the latter species are continuous across the chamber margins. Figure 5 is taken from topotype material from Car Nicobar; forms in the Tasman Sea are identical. Another New Zealand species, Rectuvigerina vesca (Finlay), is conspecific with $R$. striata, differing only in the smaller number of uniserially added chambers.

Rectuvigerina tasmana n. sp. Plate 17, Fig. 4.

Description. Test very elongate, thin, medium-sized, about $0.6 \mathrm{~mm}$ in length; about 3 times as long as broad; coiling triserial in initial whorl, rapidly becoming uniserial in following 3 or 4 whorls; chambers inflated, increasing in size very slowly and regularly, so that sides are subparallel; periphery lobulate; sutures indistinct behind the ornament; porous wall ornamented with longitudinal, very fine, spinose striations, about 40 in total circumference; most of the spinose striations or lines of joined spines are restricted to individual chambers; a few anastomose, and a few may cross the sutures and join those above or below; neck terminal, short, and tubelike; rarely found with a reverted lip.

Holotype. Plate 17, Fig. 4, will be deposited in the Cushman Collection at the United States National Museum.

This species is differentiated from other rectuvigerinids by its very large number of totally spinose striations. It is found only at Site 587 in samples with mixed middle bathyal and shelf benthic foraminiferal faunas, so the ecology of this species is uncertain. It is very likely to be a shallower-water species that was moved downslope with the amphisteginids, bryozoans, and elphidiums in these samples.

Siphonodosaria insecta (Schwager). Plate 16, Figs. 6-7. This is a common species in the Tasman Sea. It occurs along with Stilostomella lepidula, transitional forms to which are also shown in Plate 16. The species is identical with Paleogene, smooth siphonodosarids, one of which is called $S$. nuttalli (Cushman and Jarvis). Although $S$. nuttalli is more curvilinear than typical $S$. insecta, the species are essentially identical, and Schwager's name iakes precedence.

Stilostomella lepidula (Schwager). Plate 16, Figs. 1-4. As already discussed by Boltovskoy (1978) and Srinivasan and Sharma (1980), this is a very variable group which, through time, has produced a large number of morphotypes, most of which have been given a separate name in both the Paleogene and the Neogene. These multiple taxa have been based largely on the number and location of spines. Although Srinivasan and Sharma (1980) mention that the older taxon, S. adolphina of d'Orbigny, exemplifies some of the variation in the group, they do not adopt the older name. In Vienna Basin material, S. adolphina contains relatively few, very regularly placed large spines, which form a ring skirting the base of each chamber. It is thus most similar to the Paleogene species, Stilostomella basicarinata Hornibrook, which contains many more spines aligned into a basal, skirting, rim. Accepting these as valid species leaves $S$. lepidula to include those species more or less curvilinear, which possess few or many randomly distributed spines on the chambers, some of which may line up on the chamber margins. Stilostomella lepidula is also conspecific with Stilostomella antiIlea (Cushman) and the plexus of Stilostomella curvatura (Cushman).

In the Tasman Sea the species is relatively common at all sites. At Site 594 it is frequently found associated with radiolarian oozes and appears to be a solution-resistant species in this facies.

Textularia lythostrota (Schwager). Plate 3, Figs. 8-9. This species appears to be conspecific with Textularia bermudezi (Cushman and Todd); it is closely related to Textularia leuzingeri (Cushman and Renz), but in most cases lack the pinched periphery of that species. This is probably an intergrading plexus, because in some instances populations of $T$. lythostrota include the features of both these other species, while ranging to the wider, flatter Textularia yasicaensis Bermudez as well. In this case, they could all be lumped under the older taxon, $T$. lythostrota.
There is marked variation in the development of ridges paralleling the chamber widths; the ridges are higher at higher-latitude sites. The species is smaller at the deeper-water Site 591, and in the hemipelagic sediments at Site 594 where it is also composed of much finer grains.

Uvigerina asperula Czjeck. This uncommon species is ornamented with very numerous, discrete, and sharp spines which are all aligned longitudinally on the chambers. By this alignment it differs from the other spinose species, $U$. hispida (Plate 20, Figs. 5-6). Like $U$. hispido-costata it is more common at the deeper than at the shallower sites.

Uvigerina bortotara Finlay. Plate 19, Figs. 6. This species is very close morphologically to Uvigerina spinicostata Cushman and Jarvis, first named from Trinidad. However, the New Zealand species consistently has more low costae per chamber, and they are usually more spinose than those on the Caribbean taxon.

Uvigerina eocaena Guembel $\times$ Uvigerina mexicana Nuttall. Plate 18 , Fig. 2. This little-known species is actually very frequent in upper middle bathyal basinal facies of the late Eocene, and in the open ocean on topographic highs such as the Lord Howe Rise, the Walvis Ridge, and Rockall Bank, and in Oligocene faunas from Mediterranean slope basins (Boersma, 1984a). It occurs onshore in New Zealand in the late Eocene, and in the late Eocene and early Oligocene in the Tasman Sea where, however, it is not very common. Tasman forms demonstrate more rapid chamber enlargement resulting in a broader, more squat test than typical Mediterreanean types. Tasman $U$. eocaena $\times U$. mexicana also possesses more costae which, however, are less continuous than in the Mediterreanean and adjacent areas.

Uvigerina interruptata-costata Le Roy. Plate 20, Fig. 7. This species is common in the Tasman Sea. Although it closely resembles $U$. dirupta (Plate 19, Figs. 3-4), it is distinguishable by the fact that the costae are barely more than striae and the aligned, broken segments of the costae are also very fine. Like the other hispido-costate uvigerinids, this species is more common at the deeper than at the shallower sites.

Uvigerina hornibrooki Boersma. Plate 18, Fig. 1. This species, described in 1984 from the Tasman Sea (Boersma, 1984a) is somewhat similar to $U$. macrocarinata Papp and Turnovsky from the Vienna Basin. That species, however, has several costae which are continuous over one or more chambers. Its costae are much less bladelike, more numerous, and the wall is distinctly less porous.

Uvigerina hornibrooki occurs only in the latest Miocene and early Pliocene in the Tasman Sea and only at the middle bathyal sites. It was not found on the Tasman Rise.

Uvigerina tasmana Boersma. Plate 18, Fig. 4 . This is a very unusual uvigerinid because of its loosely appressed chambers and relatively platy costae which wind around the neck, forming spinelike projections out from the neck. It is consistently wider and more bulbous in the lower half of the test. It is also restricted in its distribution to subtropical and lower latitudes, but it occurs in both the shallower and the deeper lower-latitude sites. It is not frequent in either the latest Miocene or early Pliocene.

Vulvulina pennatula (Batsch). This species occurs through the entire section from the late Eocene through the Pliocene. It is generally found without final spiroplectaminid chambers, except at Site 586 where a long uniserial portion is developed. The character of the ridges varies markedly from one location to the next.

\section{ACKNOWLEDGMENTS}

The author wishes to express her special thanks to Dr. Bill Ventress and Mr. Dennis Greig of Chevron, U.S.A., in New Orleans, for providing the excellent scanning micrographs of Tasman Sea benthics. Dr. C. Srinivasan very kindly aided in the identification and picking of some of the benthic foraminifers. Drs. J. Kennett, B. Corliss, and D. Schnitker reviewed and improved the manuscript. This research was sponsored under the Bathyal Benthic Project administrated by Dr. W. A. Berggren at Woods Hole. I am profoundly grateful to Dr. Berggren for his continuing support.

\section{REFERENCES}

Backman, J., 1979. Pliocene biostratigraphy of DSDP sites 111 and 116 from the North Atlantic Ocean and the age of Northern Hemisphere glaciation. Stockholm Contrib. Geol., 32:115-137.

Barker, R. W., 1960. Taxonomic Notes on the Species Figured by $H$. B. Brady in his Report on the Foraminifera Dredged by H.M.S. 
Challenger during the Years 1873-1876. Soc. Econ. Paleontol. Mineral. Spec. Publ., 9.

Beckman, J. P., 1953. Die Foraminiferen der Oceanic Formation (Eocaen-Oligocaen) von Barbados Kl. Antillen. Eclogae Geol. Helv., 46:301-412.

Blanc, P., and Duplessy, J., 1982. The deep-water circulation during the Neogene and the impact of the Messinian salinity crisis. DeepSea Res., 29:1391-1414.

Boersma, A., 1984a. Handbook of Common Tertiary Uvigerina: Stony Point, N.Y. (Microclimates Press). 1984b. Oligocene and other Tertiary benthic foraminifers from a depth traverse down Walvis Ridge, Deep Sea Drilling Project Leg 74, Southeast Atlantic. In Hay, W. W., Sibuet, J. C., et al., Init. Repts. DSDP, 75: Washington (U.S. Govt. Printing Office), 1273-1299.

1984c. Pliocene planktonic and benthic foraminifers from the southeastern Atlantic Angola Margin: Leg 75, Site 532, Deep Sea Drilling Project. In Hay, W. W., Sibuet, J. C., et al., Init. Repts. DSDP, 75: Washington (U.S. Govt. Printing Office), 657-670. 1985. Oligocene benthic Foraminifers from North Atlantic sites: Benthic foraminifers as water-mass indexes in the North and South Atlantic. In Bougault, H., Cande, S. C., et al., Init. Repts. DSDP, 82: Washington (U.S. Govt. Printing Office), 611-628. , in press. Eocene/Oligocene Atlantic paleoceanography using benthic foraminifera. Palaeogeogr. Palaeoclimatol. Palaeoecol.

Boersma, A., Shackleton, N., Hall, M., and Given, Q., 1979. Carbon and oxygen isotope records at DSDP Site 384 (North Atlantic) and some Paleocene paleotemperatures and carbon isotope variations in the Atlantic Ocean. In Tucholke, B. E., Vogt, P. R., et al., Init. Repts. DSDP, 43: Washington (U.S. Govt. Printing Office), 695-717.

Boltovskoy, E., 1978. Late Cenozoic benthonic foraminifera of the Ninetyeast Ridge (Indian Ocean). Mar. Geol., 26:139-175.

Bremer, M., and Lohman, G., 1982. Evidence for primary control of the distribution of certain Atlantic Ocean benthonic foraminifera by degree of carbonate saturation. Deep Sea Res., 29:987-998.

Corliss, B. H., 1981. Deep sea benthonic foraminiferal faunal turnover near the Eocene/Oligocene boundary. Mar. Micropaleontol., 6:367-384.

Finlay, H. J., 1939. New Zealand Foraminifera: key species in stratigraphy. Trans. $R$. Soc. N.Z., 69:89-128.

Hagn, H., 1956. Geologische und paläontologische Untersuchungen im Tertiär des Monte Brione und seiner Umgebung. Palaeontographia, $A, 107(3-6): 67-210$

Heath, G. R., Moore, T. C., and Dauphin, J. P., 1977. Organic carbon in deep-sea sediments. In Andersen, N. R., and Malahoff, A. (Eds.), The Fate of Fossil Fuel $\mathrm{CO}_{2}$ in the Oceans: New York (Plenum Press), pp. 605-625.

Hornibrook, N. de B., 1971. A revision of the Oligocene and Miocene Foraminifera from New Zealand described by Karrer and Stache in the Reports of the "Novara" Expedition (1864), Bull. N.Z. Geol. Surv. Paleont., 43:5-85.

Keigwin, L. D., Jr., and Shackleton, N. J., 1980. Uppermost Miocene carbon isotope stratigraphy of a piston core in the equatorial $\mathrm{Pa}$ cific. Nature, 284:613-314.

Leinen, M., 1979. Biogenic silica accumulation in the central equatorial Pacific and its implications for Cenozoic paleoceanography: summary. Geol. Soc. Am. Bull., 90:803-810.

Lohman, G. D., 1978. Abyssal benthonic foraminifera as hydrographic indicators in the Western South Atlantic. J. Foraminiferal Res., 8: 6-34.

Lutze, G. F., 1978. Neogene Benthonic foraminifera from Site 369, Leg 41, Deep Sea Drilling Project, In Lancelot, Y., Seibold, E., et al., Init. Repts. DSDP, 41: Washington (U.S. Govt. Printing Office), 41:659-666.

Lutze, G., and Coubourn, J., 1983. Recent benthic foraminifera from the continental margin of northwest Africa-community structure and distribution. Mar. Micropaleontol., 8:361-401.

Matthews, R. K., and Poore, R. Z., 1980. Tertiary $\delta^{18} \mathrm{O}$ record and glacioeustatic sea-level fluctuations. Geology, 8:501-504.
Orbigny, Alcide d', 1846. Foraminiferes fossiles du bassin tertiaire de Vienne (Autriche) [Die fossilen Foraminiferen des tertiaren Beckens von Wien]: Paris (Gide).

Parker, W. K., Jones, T. R., and Brady, H. B., 1865. On the nomenclature of the foraminifera. Pt. 12. The Species enumerated by d'Orbigny in the "Annales des Sciences Naturelles", Vol. 7, 1826. Ann and Mac. Nat. Hist., Ser 3. 16:15-41.

Prell, W. L., 1982. Temporal and spatial patterns of monsoonal upswelling along Arabia: a modern analogue for the interpretation of Quaternary SST anomalies. J. Mar. Res., 40:143-155.

Prell, W. L., and Curry, W. B., 1981. Faunal and isotopic indices of monsoonal upwelling: western Arabian Sea. Oceanol. Acta, 4: 91-98.

Reuss, A. E., 1851. Über die fossilen Foraminiferen und Entomostracen der Septarienthone der Umgegend von Berlin. Z. Geol. Ges., 3:49-91.

Savin, S. M., Douglas, R. G., Keller, G., Killingley, J. S., Shaughnessy, L., Sommer, M. A., Vincent, E., and Woodruff, F., 1981. Miocene benthic foraminiferal isotope records: a synthesis. Mar. Micropaleontol., 6:423-450.

Schwager, C., 1866. Fossile Foraminiferen von Kar Nicobar. Novara Exped., Geol., Pt. 2:187-268.

Shackleton, N. J., Backman, J., Zimmerman, H., Kent, D. V., Hall, M. A., Roberts, D. G., Schnitker, D., Bauldauf, J. G., Desprairies, A., Homrighausen, R., Huddlestun, P., Keene, J. B., Kaltenback, A. J., Krumsiek, K. A. O., Morton, A. C., Murray, J. W., and Westberg-Smith, J., 1984. Oxygen isotopic calibration of the onset of ice rafting and history of glaciation in the North Atlantic region. Nature, 307:620-623.

Shackleton, N. J., Hall, M. A., and Boersma, A., 1984. Oxygen and carbon isotope data from leg 74 foraminifers. In Moore, T. C., Jr., Rabinowitz, P. D., et al., Init. Repts. DSDP, 74: Washington (U.S. Govt. Printing Office), 599-612.

Shackleton, N. J., and Kennett, J. P., 1975. Paleotemperature history of the Cenozoic and the initiation of Antarctic glaciation: oxygen and carbon isotope analyses in DSDP Sites 277, 279 and 281. In Kennett, J. P., Houtz, R. E., et al., Init. Repts. DSDP, 29: Washington (U.S. Govt. Printing Office), 743-755.

Schnitker, D., 1980. North Atlantic oceanography as possible cause of Antarctic glaciation and eutrophication. Nature, 284:615-616.

Srinivasan, M. S., and Sharma, V., 1980. Schwager's Car Nicobar Foraminifera in the Reports of the Novara Expedition: a Revision. New Delhi (Today and Tomorrow Press).

Tjalsma, L. C., 1983. Eocene to Miocene benthic foraminifers from DSDP Site 516, Rio Grande Rise, South Atlantic In Barker, P. F., Carlson, R. L., Johnson, D. A., et al., Init. Repts. DSDP, 72: Washington (U.S. Govt. Printing Office), 731-755.

Tjalsma, L. C., and Lohman, G., 1983. Paleocene-Eocene bathyal and abyssal benthic foraminifera from the Atlantic Ocean. Micropaleontology Spec. Publ., 4.

Vincent, E., Killingley, J., and Berger, W., 1980. The Magnetic Epoch6 carbon shift: a change in the ocean's ${ }^{13} \mathrm{C} /{ }^{12} \mathrm{C}$ ratio 6.2 million years ago. Mar. Micropaleontol., 5:185-203.

Woodruff, F., 1979. Deep sea benthic foraminiferal changes associated with the middle Miocene oxygen isotopic event, DSDP Site 289, equatorial Pacific [Ph.D. dissert.]. Univ. of Southern California.

Woodruff, F., and Douglas, R. G., 1981. Response of deep sea benthic foraminifera to Miocene paleoclimatic events, DSDP Site 289. Mar. Micropaleontol., 6:617-632.

Woodruff, F., and Savin, S., 1981. Miocene stable isotope record: a detailed deep Pacific Ocean study and its paleoclimatic implications. Science, 122:665-668.

, in press. $\delta^{13} \mathrm{C}$ values of Miocene Pacific benthic foraminifera: correlations with sea level and biological productivity. Geology.

Date of Initial Receipt: 1 November 1984

Date of Acceptance: 8 April 1985 


\section{A. BOERSMA}

\section{APPENDIX}

Appendix Tables 1-22 include the presence-absence data for all common benthic foraminiferal species identified at each site. Presence is indicated by $\mathrm{x}$; if a species is very abundant in any particular sample, that is signalled by A. Preservation of the carbonate in each sample is ranked on the scale P, poor; F, fair, M, moderate; G, good; E, excellent. For most time periods the total number of species identified is indicated also on the diagram. In all Pliocene sections, the number of species per sample and the number of rectilinear species per sample is indicated. Also counted were the total number of species identified at the site in that time period, and the total number of rectilinear and agglutinated species. All data are plotted against the zonation of Jenkins and Srinivasan, this volume.

Table 1. Benthic foraminifers, Hole 586B, late Miocene.

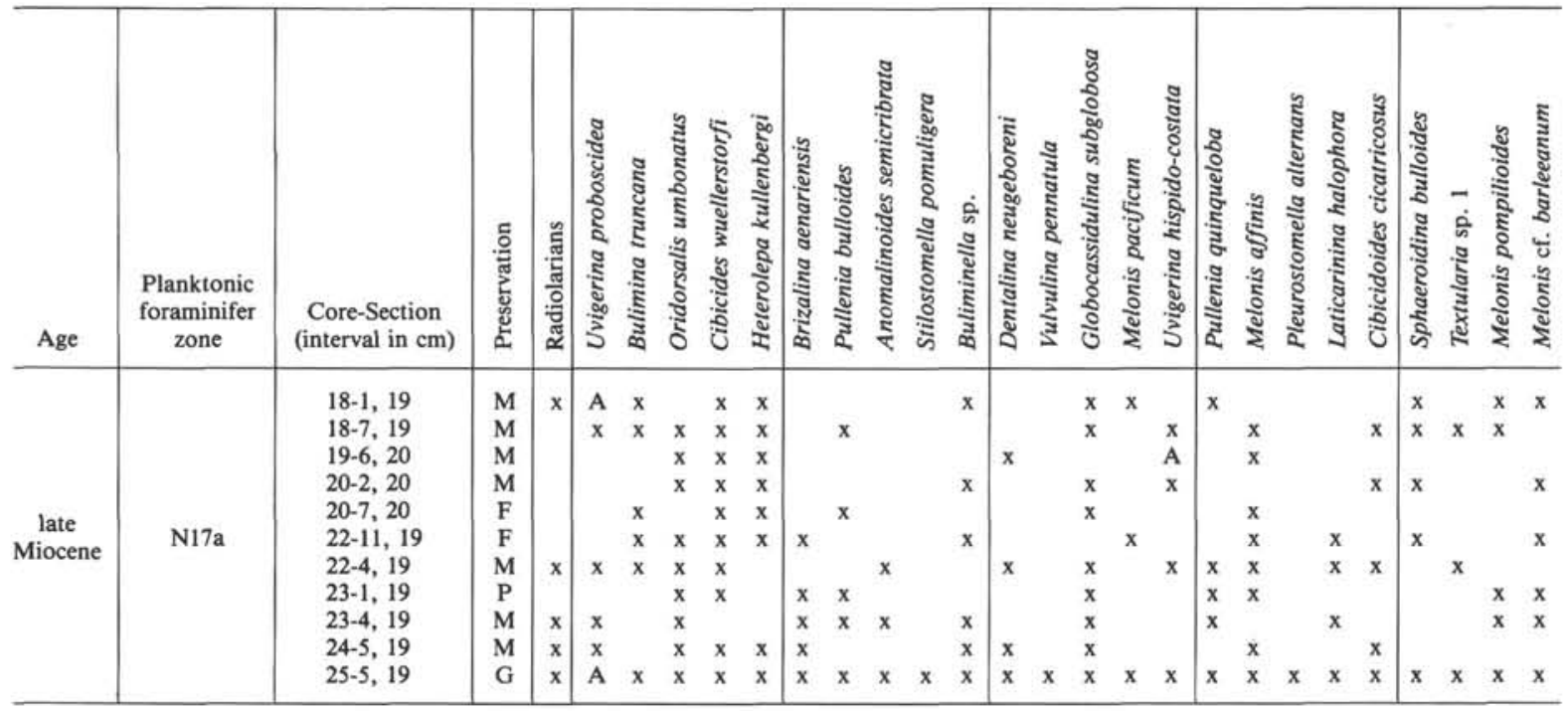

Table 2. Benthic foraminifers, Hole 586B, Pliocene.

\begin{tabular}{|c|c|c|c|c|c|c|c|c|c|c|c|c|c|c|c|c|c|c|c|c|c|c|c|c|c|c|c|c|c|c|}
\hline Age & $\begin{array}{c}\text { Planktonic } \\
\text { foraminifer } \\
\text { zone }\end{array}$ & $\begin{array}{l}\text { Core-Section } \\
\text { (interval in } \mathrm{cm} \text { ) }\end{array}$ & 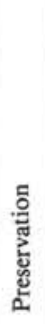 & 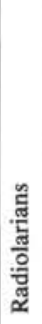 & 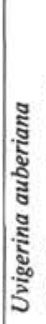 & 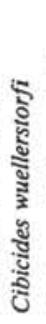 & 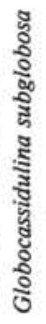 & 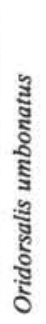 & 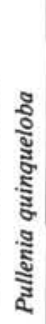 & 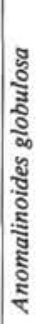 & 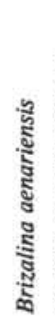 & 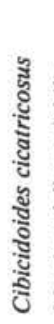 & 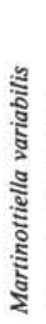 & 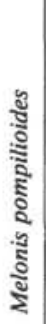 & 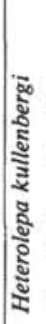 & 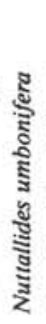 & 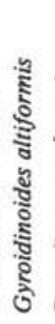 & 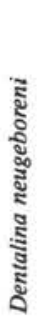 & 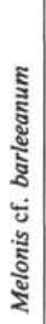 & 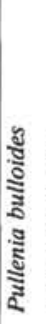 & 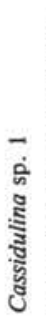 & 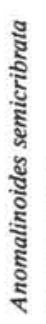 & है & 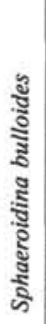 & 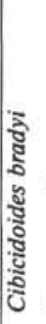 & 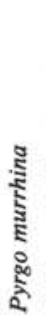 & 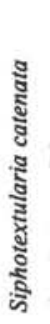 & 용 & 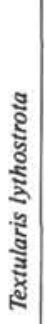 & 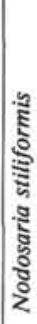 \\
\hline \multirow[t]{4}{*}{ Pliocene } & N21 & $\begin{array}{l}5-1,90 \\
5-2,110 \\
5-3,108 \\
5-4,106 \\
5-6,56 \\
6-1,108 \\
6-3,108 \\
6-6,108 \\
8-7,20\end{array}$ & $\begin{array}{c}P \\
M \\
G \\
G \\
G \\
G \\
M \\
M \\
F\end{array}$ & $\begin{array}{l}\mathrm{x} \\
\mathrm{x} \\
\mathrm{x} \\
\mathrm{x} \\
\\
\mathrm{x} \\
\mathrm{x}\end{array}$ & $\begin{array}{l}\mathrm{x} \\
\mathrm{x} \\
\mathrm{x} \\
\mathrm{x} \\
\mathrm{x} \\
\mathrm{x} \\
\mathrm{x}\end{array}$ & $\begin{array}{l}\mathrm{x} \\
\mathrm{x} \\
\mathrm{x} \\
\mathrm{x} \\
\mathrm{x} \\
\mathrm{x} \\
\mathrm{x}\end{array}$ & $\begin{array}{l}x \\
x\end{array}$ & $\begin{array}{l}\mathrm{x} \\
\mathrm{x} \\
\mathrm{x} \\
\mathrm{x}\end{array}$ & $\begin{array}{l}x \\
x\end{array}$ & & $\begin{array}{l}x \\
x\end{array}$ & & & $x$ & $\begin{array}{l}x \\
x\end{array}$ & $\begin{array}{l}\mathrm{x} \\
\mathrm{x} \\
\mathrm{x} \\
\mathrm{x}\end{array}$ & $x$ & & & $\begin{array}{l}x \\
x \\
x \\
x \\
x\end{array}$ & & $\begin{array}{l}x \\
x \\
x\end{array}$ & $\begin{array}{l}x \\
x \\
x\end{array}$ & & $\begin{array}{l}x \\
x\end{array}$ & $\begin{array}{l}\mathrm{x} \\
\mathrm{x} \\
\mathrm{x} \\
\mathrm{x} \\
\mathrm{x}\end{array}$ & & & & $x$ \\
\hline & N19-20 & $\begin{array}{l}11-4,66 \\
12-1,66 \\
13-4,18\end{array}$ & $\begin{array}{l}F \\
F \\
F\end{array}$ & $\begin{array}{l}\mathrm{x} \\
\mathrm{x}\end{array}$ & $\begin{array}{l}\mathrm{A} \\
\mathrm{A} \\
\mathrm{X}\end{array}$ & $\begin{array}{l}x \\
x\end{array}$ & $\begin{array}{l}x \\
x\end{array}$ & $\begin{array}{l}x \\
x\end{array}$ & & & $x$ & & $x$ & $\mathrm{x}$ & & $\mathrm{x}$ & & $x$ & $\begin{array}{l}x \\
x\end{array}$ & $x$ & & $\begin{array}{l}\mathrm{x} \\
\mathrm{x}\end{array}$ & $x$ & $x$ & & $\begin{array}{l}x \\
x\end{array}$ & & $x$ & & \\
\hline & N18 & $\begin{array}{l}14-1,66 \\
15-4,66 \\
17-2,70\end{array}$ & $\begin{array}{c}\mathrm{M} \\
\mathrm{M} \\
\mathrm{F}\end{array}$ & $\begin{array}{l}x \\
x\end{array}$ & $\begin{array}{l}\text { X } \\
\text { A }\end{array}$ & $\begin{array}{l}\mathrm{x} \\
\mathrm{x} \\
\mathrm{x}\end{array}$ & $\begin{array}{l}x \\
x\end{array}$ & $x$ & & $\mathrm{x}$ & $x$ & $\mathrm{x}$ & & $\mathrm{x}$ & $\begin{array}{l}x \\
x\end{array}$ & & & & $\begin{array}{l}x \\
x\end{array}$ & & & & $\mathrm{x}$ & $\begin{array}{l}x \\
x\end{array}$ & $x$ & $\mathbf{x}$ & $x$ & $\mathrm{x}$ & & $x$ \\
\hline & $\mathrm{N} 17 \mathrm{~b}$ & $17-6,19$ & M & & $x$ & $\mathrm{x}$ & $x$ & $x$ & $x$ & $x$ & $x$ & $x$ & $x$ & $x$ & $x$ & $\mathrm{x}$ & $x$ & $x$ & $x$ & $x$ & $x$ & & & & & & & & & \\
\hline
\end{tabular}


Table 1. (Continued).

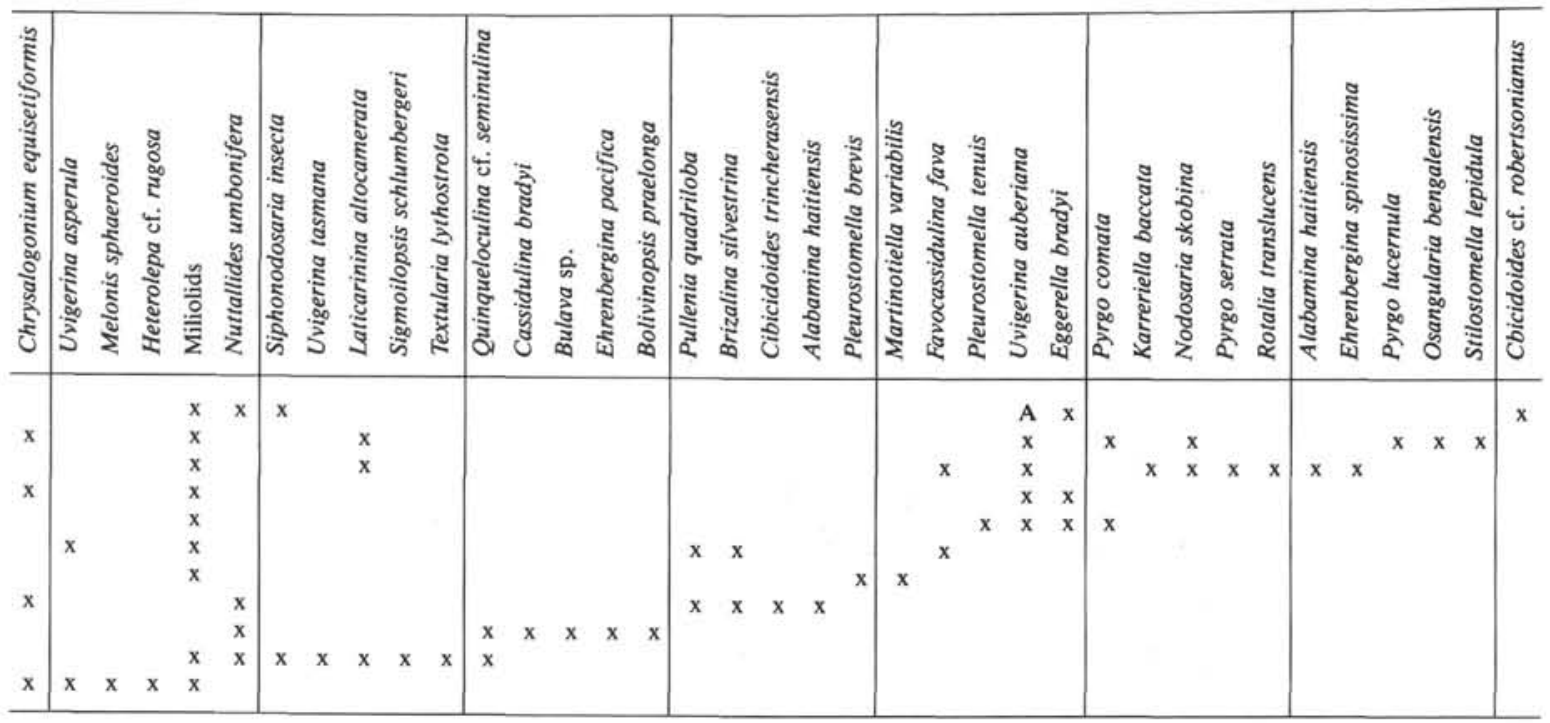

Table 2. (Continued).

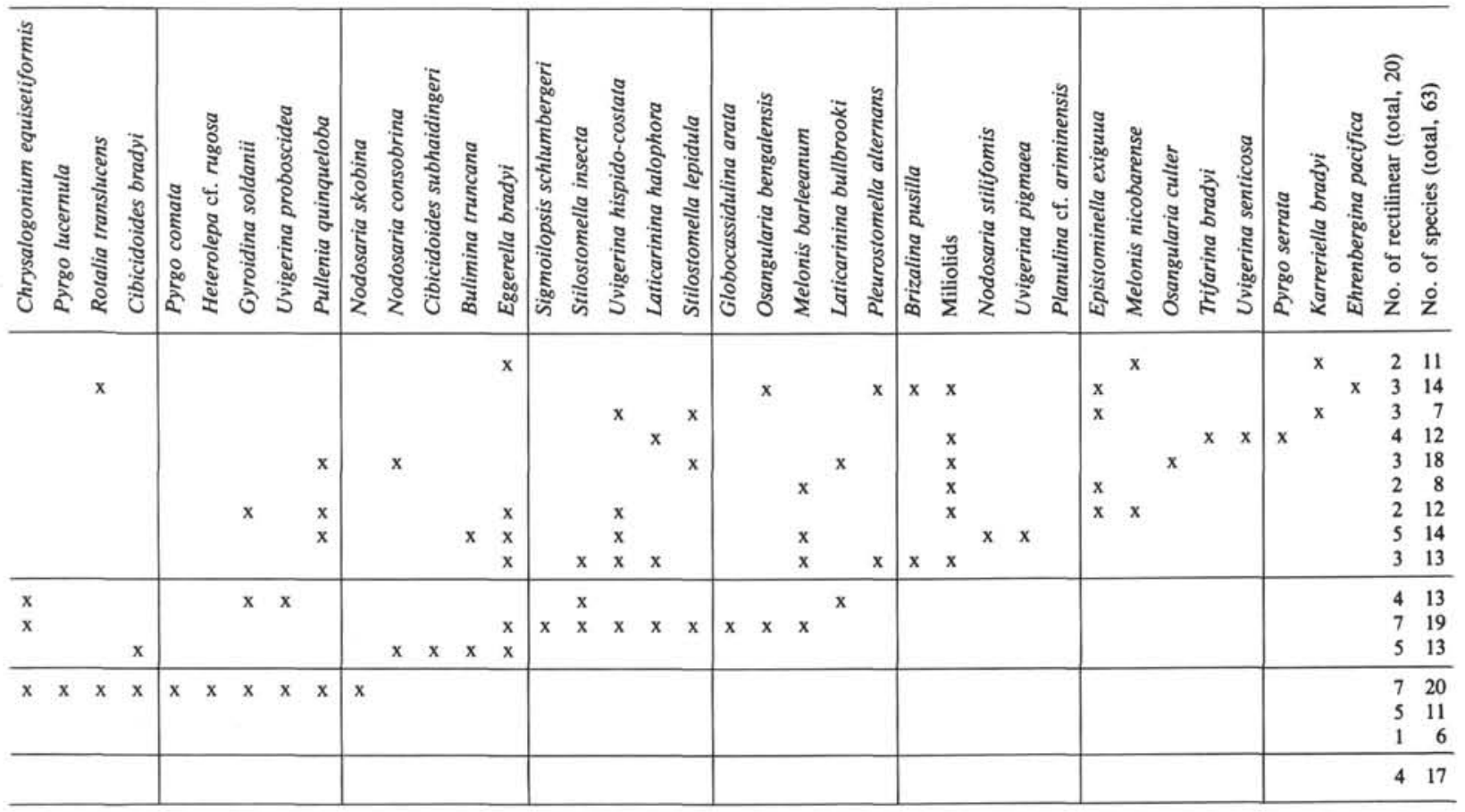




\section{A. BOERSMA}

Table 3. Benthic foraminifers, Site 588, early-middle Miocene.

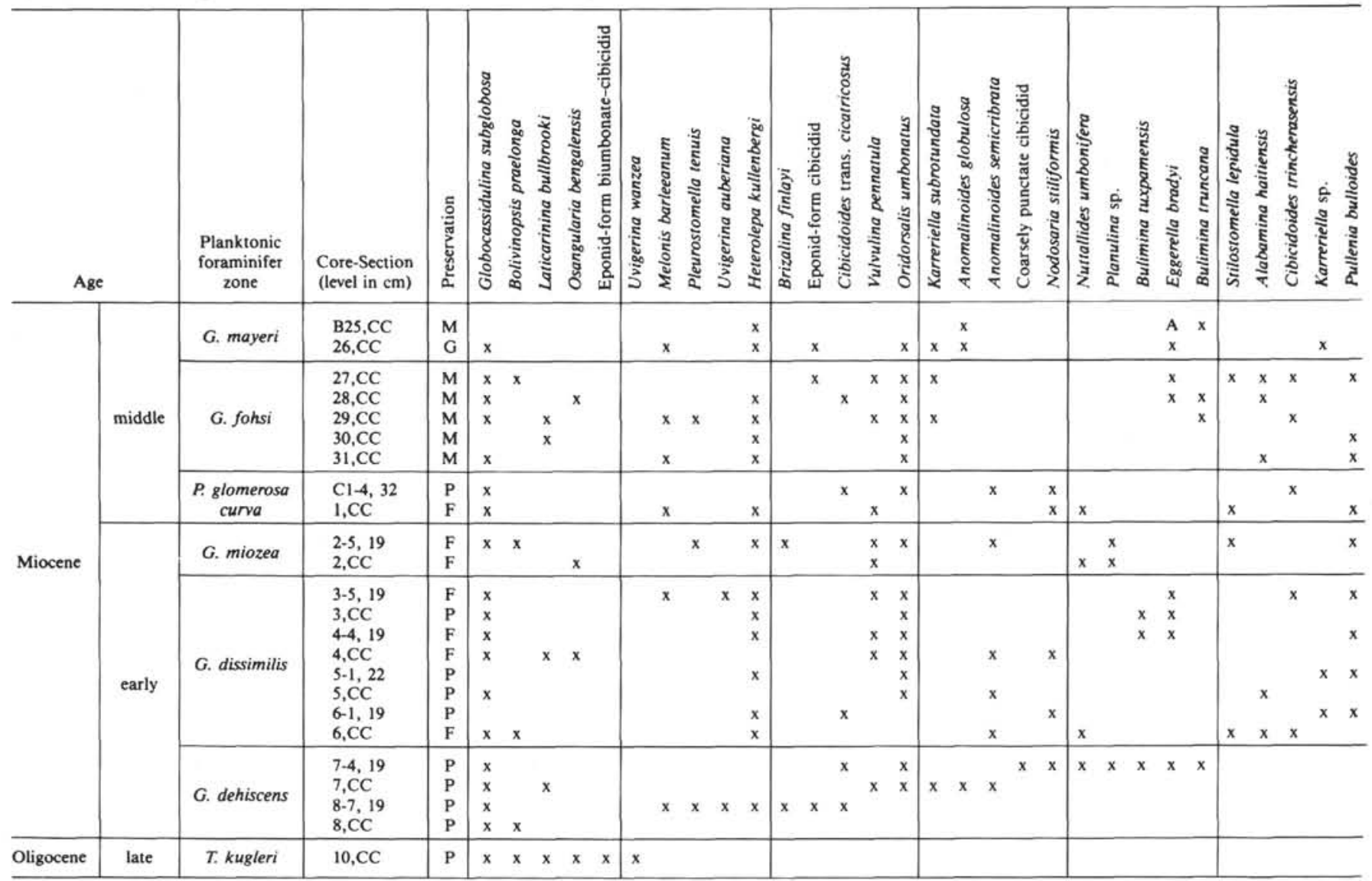

Note: B and C indicate cores from Holes 588B and 588C, respectively. 
Table 3. (Continued).

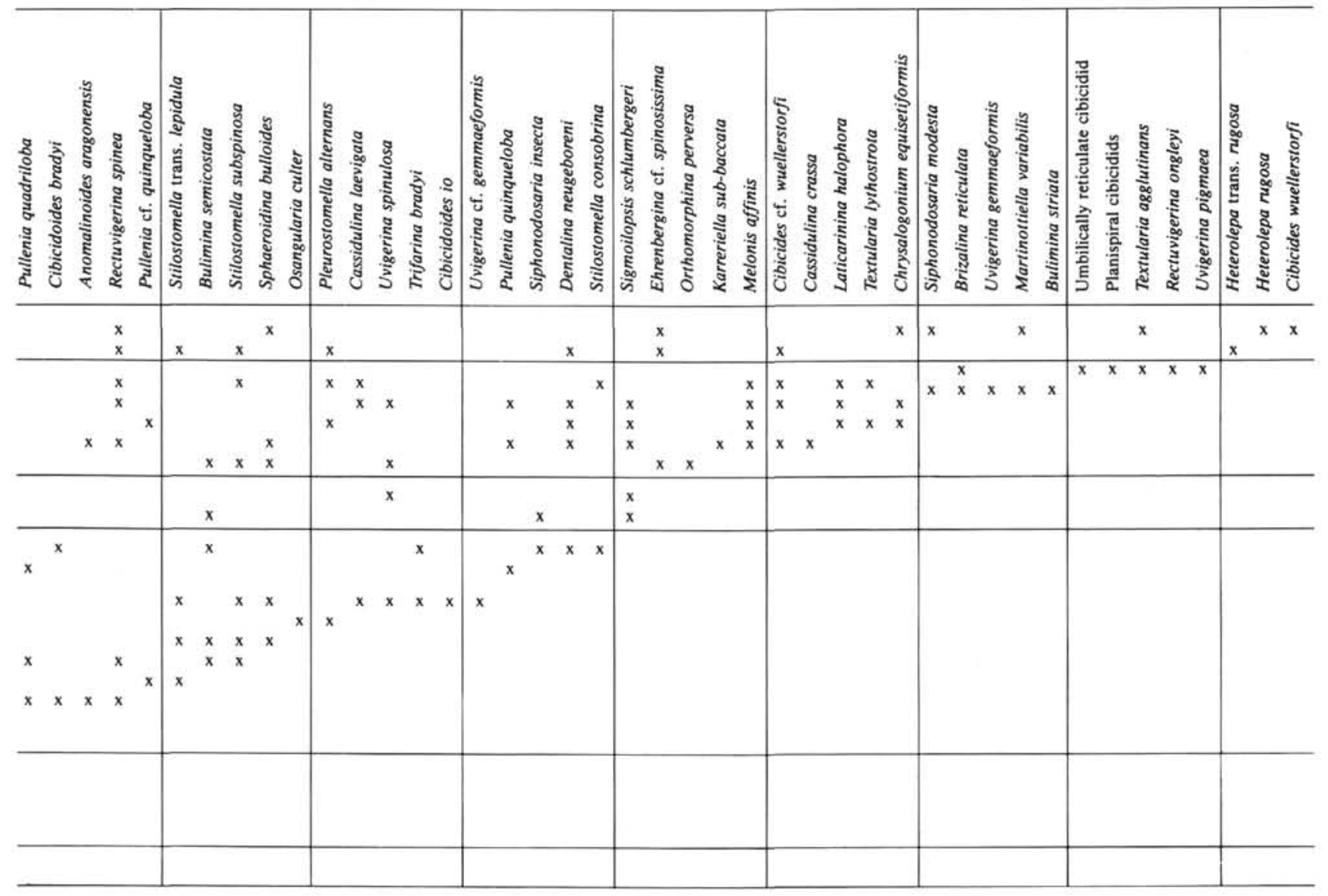


Table 4. Benthic foraminifers, Site 588, middle to late Miocene.

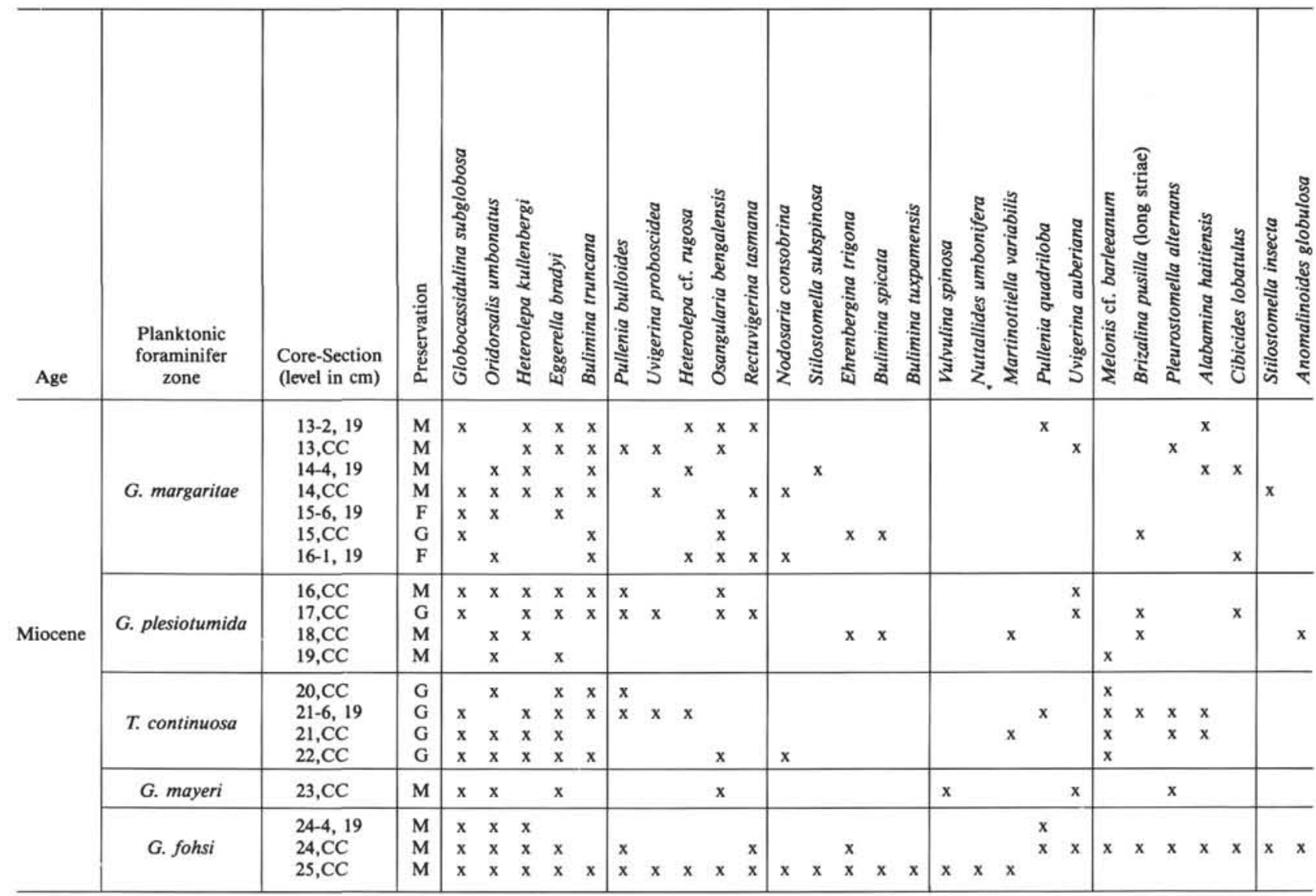

Note: Total no. of species, 60 .

Table 5. Benthic foraminifers, Site 588, Pliocene.

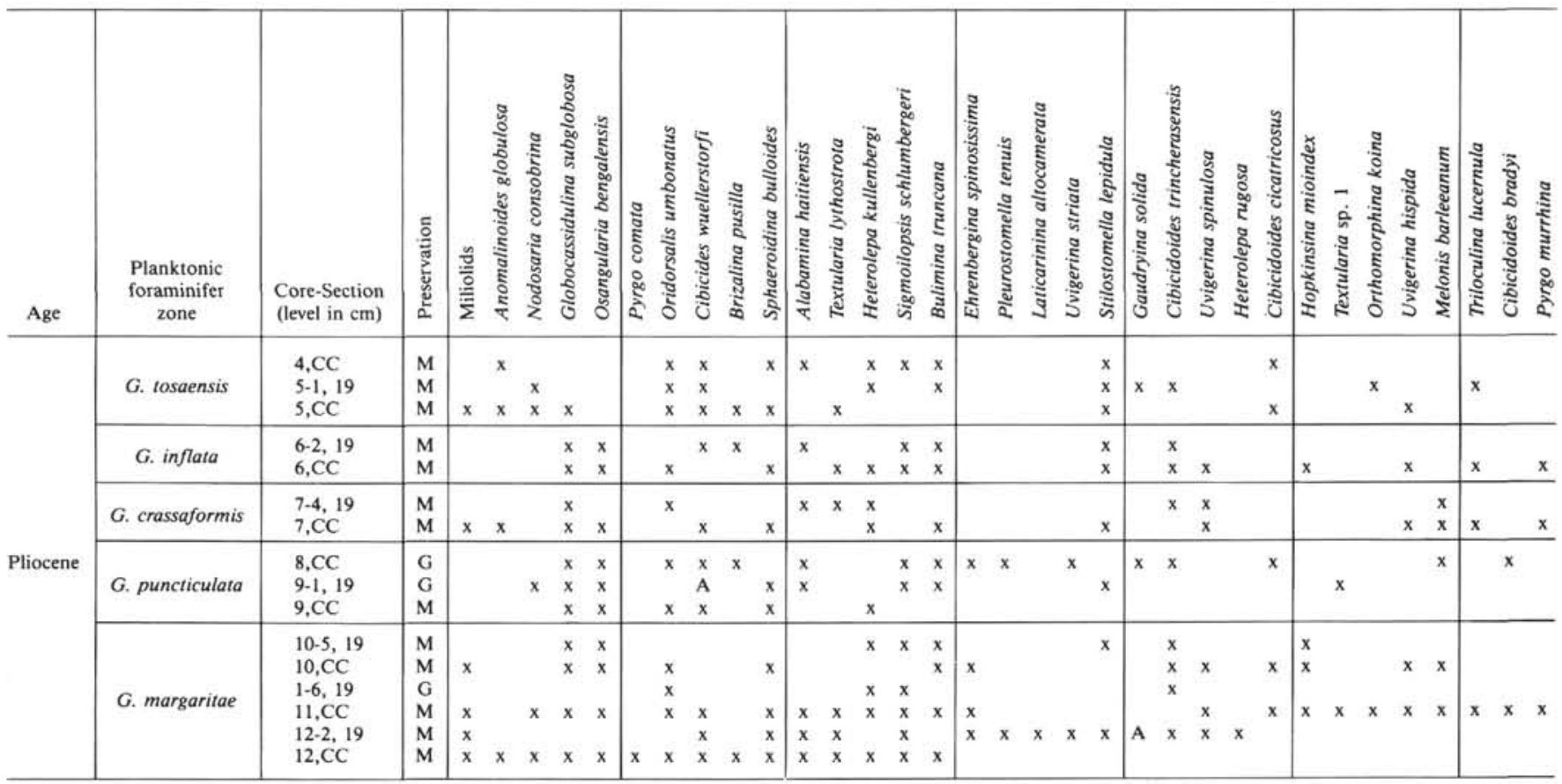




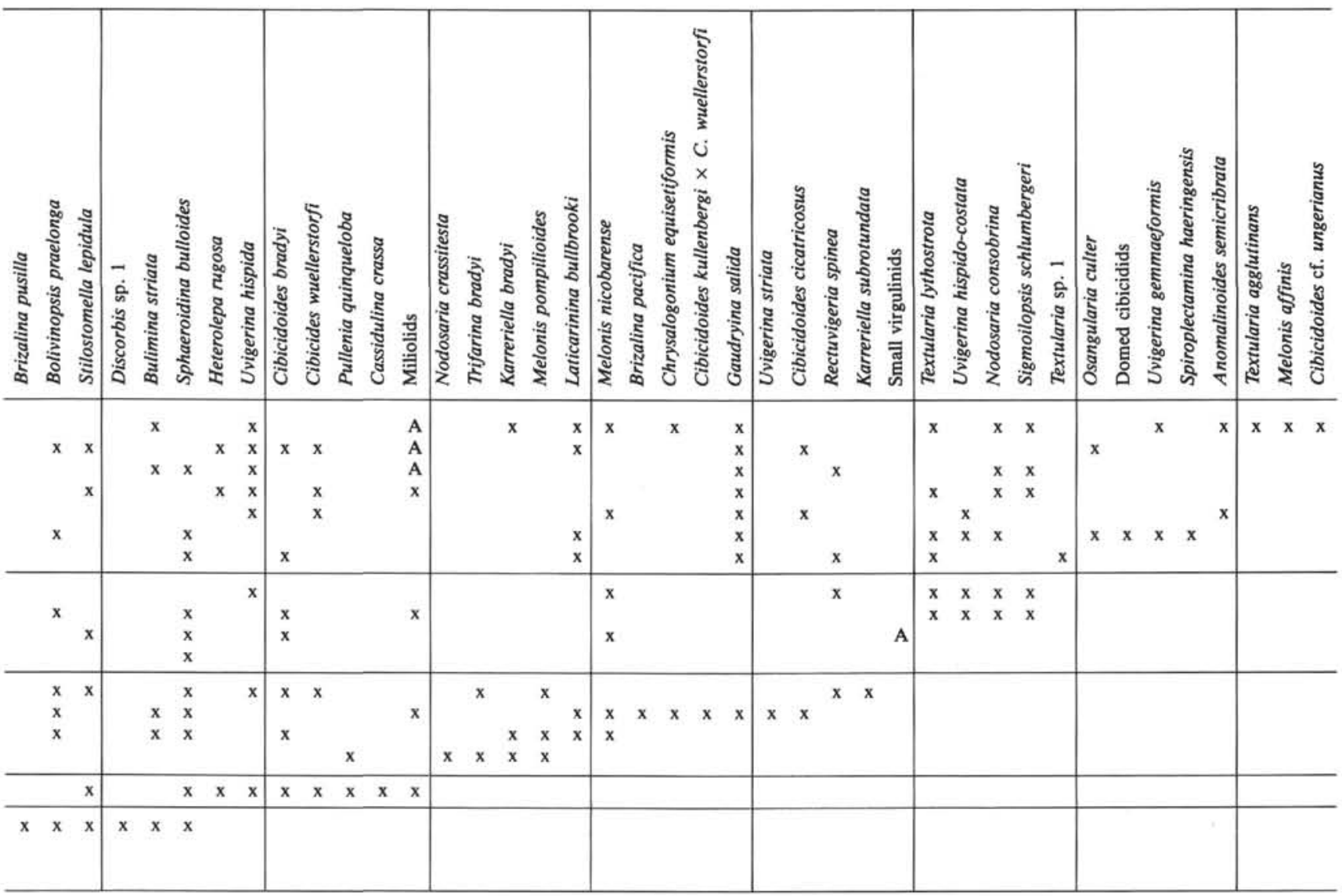

Table 5 (Continued).

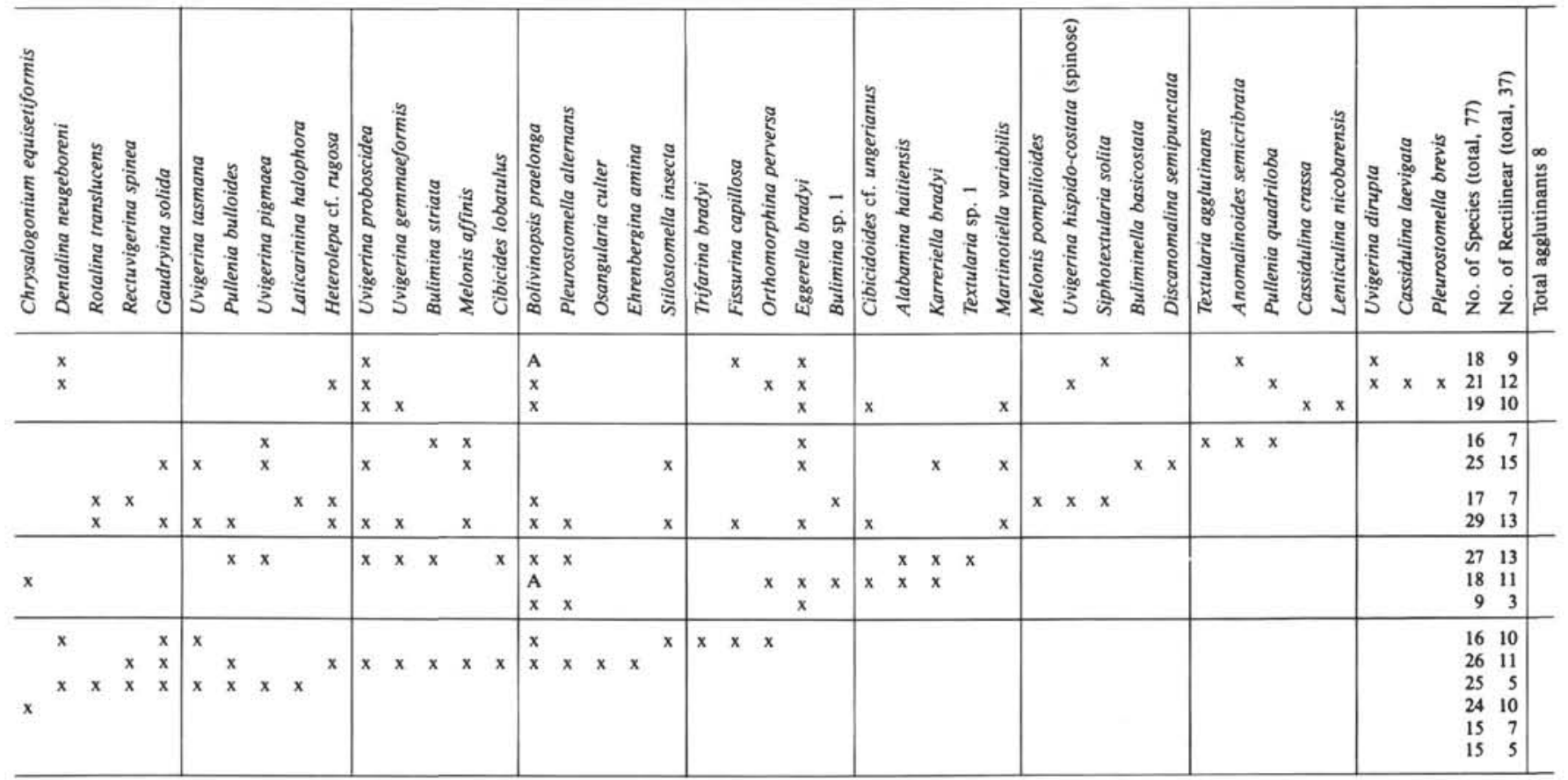


Table 6. Benthic foraminifers, Hole 590B, early-middle Miocene.

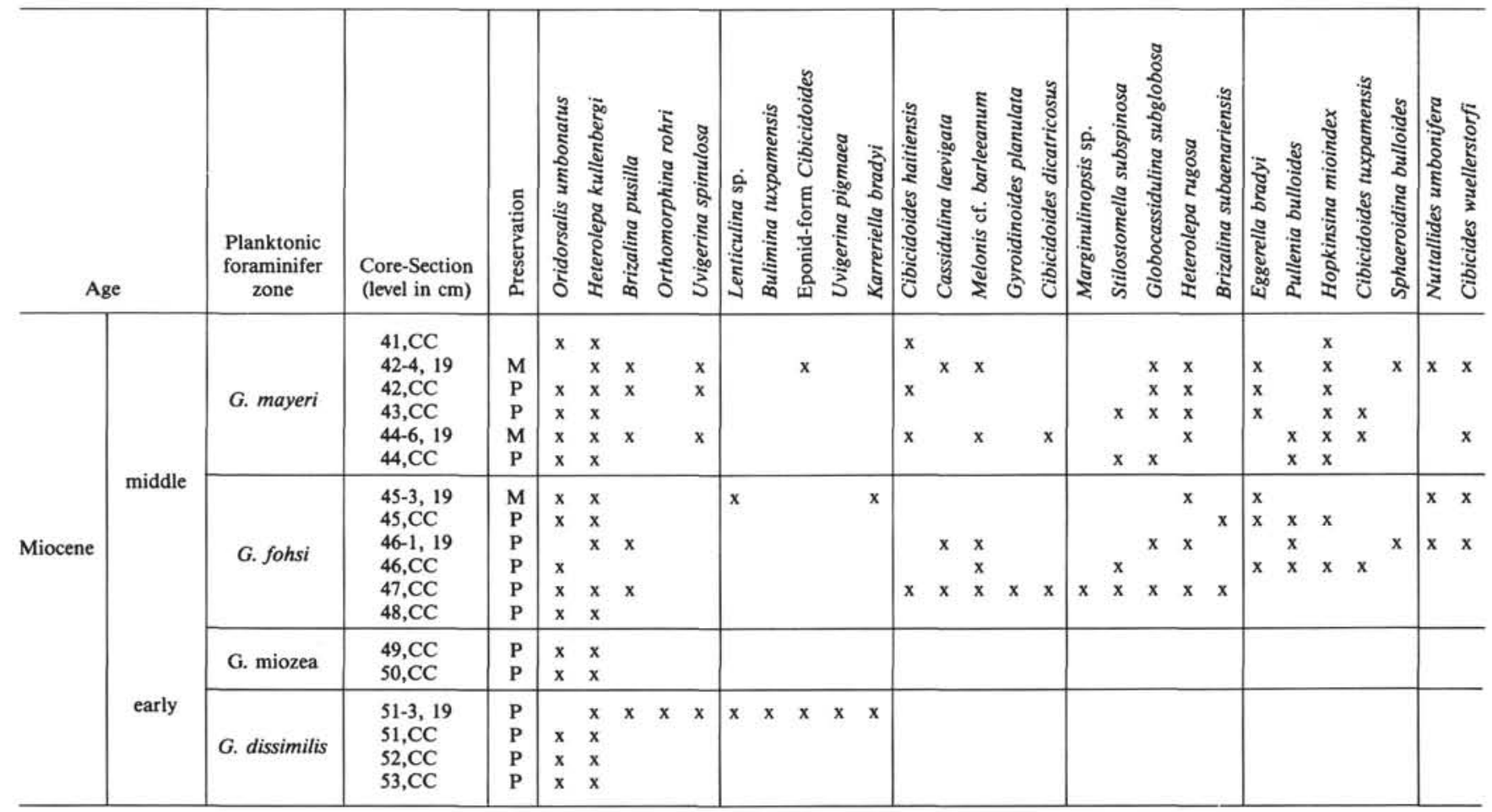

Table 7. Benthic foraminifers, Site 590 , middle-late Miocene.

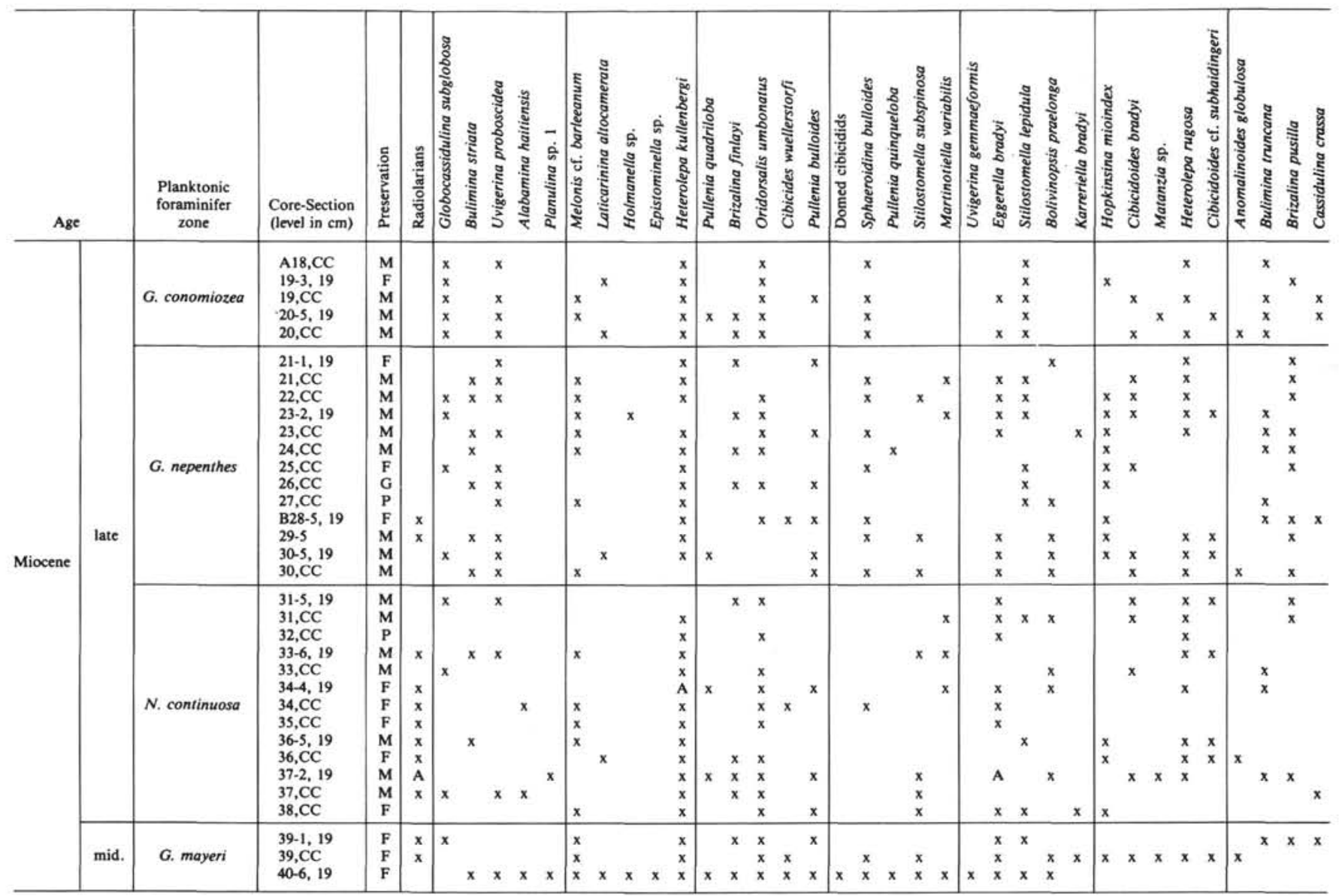

Note: $\mathrm{A}$ and $\mathrm{B}$ indicate cores from Holes $590 \mathrm{~A}$ and $590 \mathrm{~B}$. 
Table 6. (Continued).

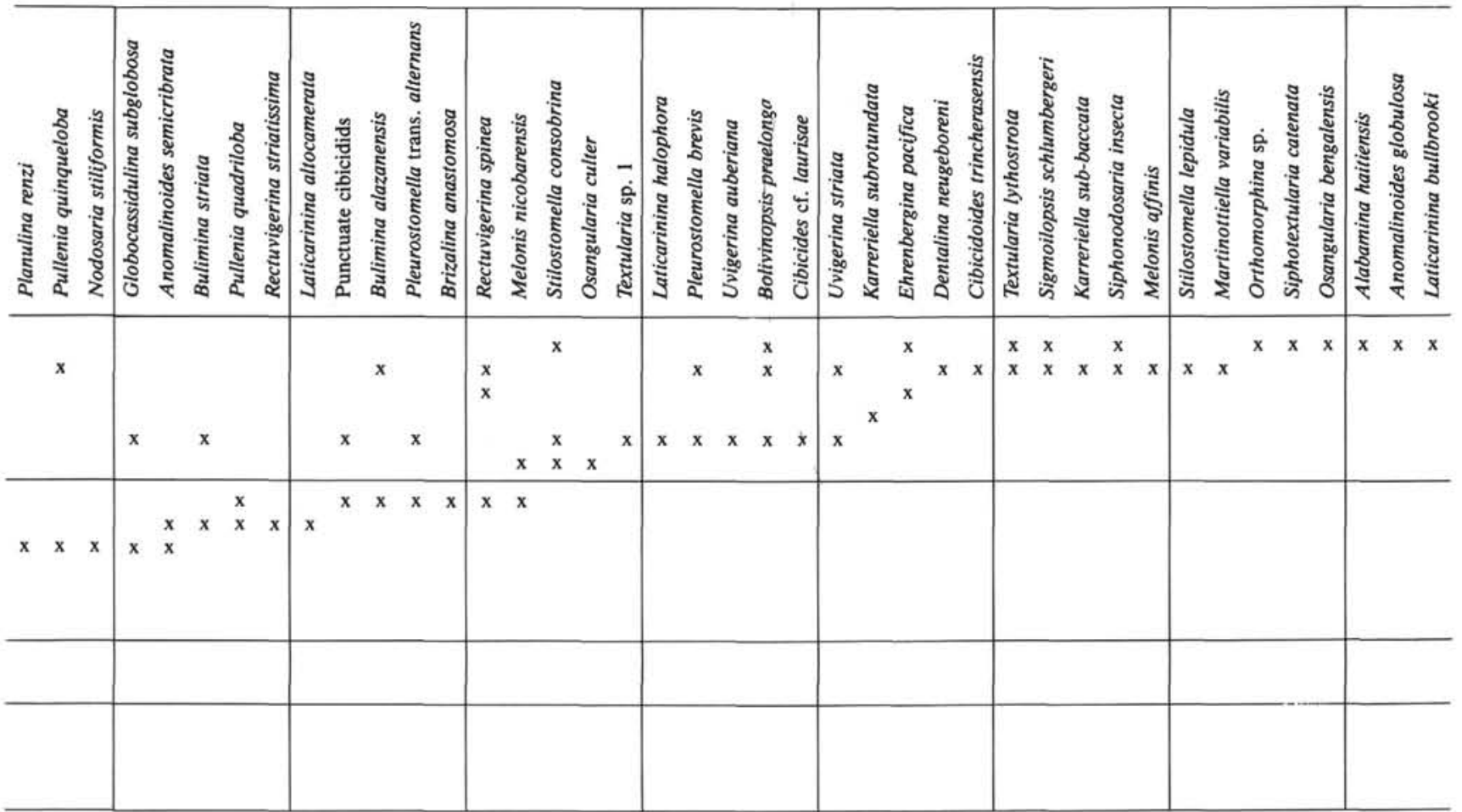

Table 7. (Continued).

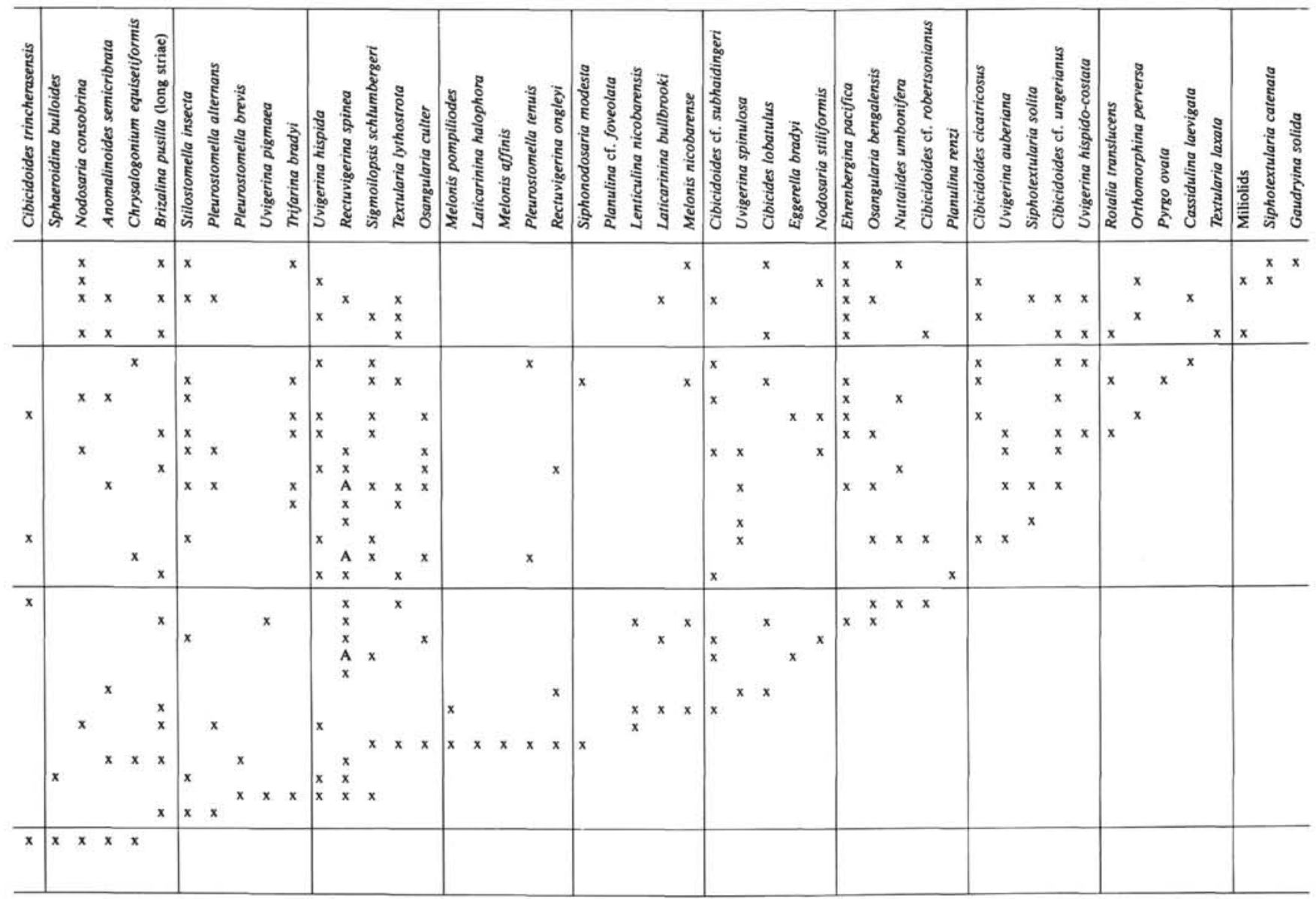


Table 8. Benthic foraminifers, Hole 590A, Pliocene.

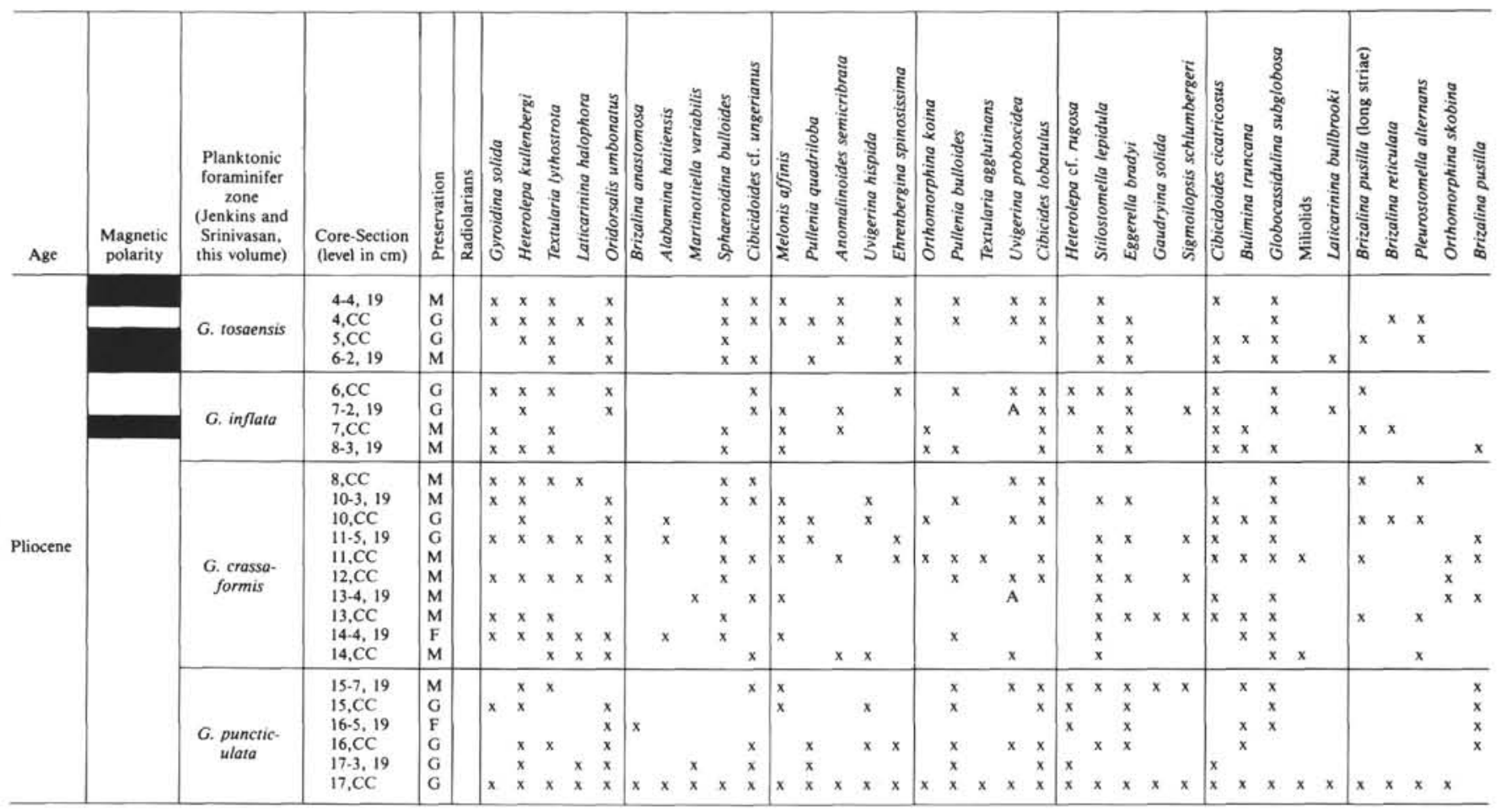

Note: Total no. of species, 83.

Table 9. Benthic foraminifers, Hole 591B, early-middle Miocene.

\begin{tabular}{|c|c|c|c|c|c|c|c|c|c|c|c|c|c|c|c|c|c|c|c|}
\hline \multicolumn{2}{|c|}{ Age } & $\begin{array}{l}\text { Planktonic } \\
\text { foraminifer } \\
\text { zone }\end{array}$ & $\begin{array}{l}\text { Core-Section } \\
\text { (level in } \mathrm{cm} \text { ) }\end{array}$ & 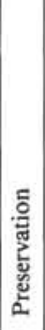 & 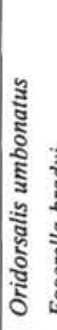 & 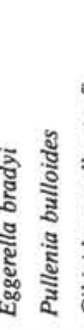 & 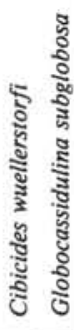 & 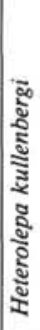 & 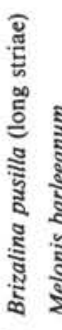 & 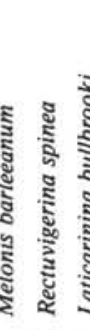 & 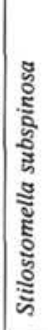 & 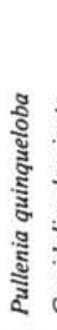 & 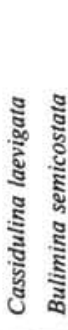 & 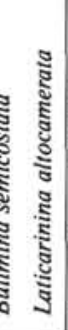 & 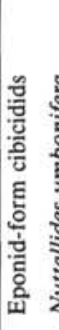 & 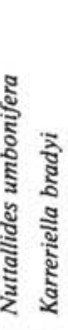 & 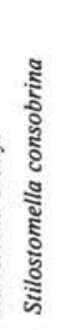 & 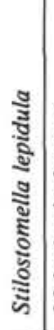 & 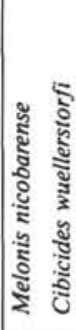 \\
\hline \multirow{6}{*}{ Miocene } & \multirow{5}{*}{ middle } & N. continuosa & $\begin{array}{l}8, \mathrm{CC} \\
9, \mathrm{CC}\end{array}$ & $\begin{array}{l}\mathrm{F} \\
\mathrm{F}\end{array}$ & $\begin{array}{l}x \\
x\end{array}$ & $\begin{array}{ll}x & x \\
x & \end{array}$ & $\mathrm{x}$ & $x$ & & $\mathrm{x}$ & $\mathrm{x}$ & & & & $x$ & $\begin{array}{l}x \\
x\end{array}$ & $x$ & $\begin{array}{l}x \\
x\end{array}$ & \\
\hline & & G. mayeri & $\begin{array}{l}10, \mathrm{CC} \\
11-1,19 \\
11, \mathrm{CC} \\
12-1,19 \\
12, \mathrm{CC} \\
13-1,19 \\
13, \mathrm{CC}\end{array}$ & \begin{tabular}{|l|}
$\mathrm{P}$ \\
$\mathrm{P}$ \\
$\mathrm{P}$ \\
$\mathrm{P}$ \\
$\mathrm{F}$ \\
$\mathrm{P}$ \\
$\mathrm{P}$
\end{tabular} & $\begin{array}{l}x \\
x \\
x \\
x \\
x\end{array}$ & $\begin{array}{ll}x & \\
x & \\
x & A \\
x & \\
x & x \\
x & \end{array}$ & $\begin{array}{cc} & \mathrm{x} \\
\mathrm{x} & \mathrm{x} \\
\mathrm{x} & \mathrm{x} \\
\mathrm{x} & \mathrm{x} \\
\mathrm{x} & \mathrm{x}\end{array}$ & $\begin{array}{l}x \\
x \\
x\end{array}$ & ${ }^{x}$ & $\begin{array}{ll} & x \\
x & \\
x & \end{array}$ & $\mathrm{x}$ & $\mathrm{x}$ & $\mathrm{x}$ & $\mathrm{x}$ & & $\begin{array}{ll}x & x \\
A & \\
& \\
A & \\
x & x\end{array}$ & & & $\mathrm{x}$ \\
\hline & & G. fohsi & $\begin{array}{l}14, \mathrm{CC} \\
15-3,19 \\
15, \mathrm{CC} \\
16, \mathrm{CC} \\
17-4,19 \\
17, \mathrm{CC}\end{array}$ & \begin{tabular}{|l|}
$\mathrm{P}$ \\
$\mathrm{F}$ \\
$\mathrm{F}$ \\
$\mathrm{P}$ \\
$\mathrm{P}$ \\
$\mathrm{P}$
\end{tabular} & \begin{tabular}{|l|}
$x$ \\
$x$ \\
$x$ \\
$x$
\end{tabular} & $\begin{array}{ll} & \\
x & \\
x & \\
x & \\
& x\end{array}$ & $\begin{array}{ll} & x \\
x & \\
x & \\
x & x \\
& x \\
x & \end{array}$ & $\begin{array}{l}\mathrm{x} \\
\mathrm{x} \\
\mathrm{A}\end{array}$ & $\mathrm{x}$ & & & & & $\begin{array}{l}\mathrm{x} \\
\mathrm{x}\end{array}$ & $\mathrm{x}$ & $x$ & $\begin{array}{l}\mathrm{x} \\
\mathrm{x}\end{array}$ & \begin{tabular}{l|}
$x$ \\
$x$
\end{tabular} & $\begin{array}{ll}x & \\
& \\
x & \\
x & \\
x & x\end{array}$ \\
\hline & & O. suturalis & $\begin{array}{l}18-4,19 \\
18, \mathrm{CC} \\
19, \mathrm{CC}\end{array}$ & \begin{tabular}{|l|}
$\mathrm{M}$ \\
$\mathrm{P}$ \\
$\mathrm{P}$
\end{tabular} & \begin{tabular}{|l|}
$x$ \\
$x$ \\
$x$
\end{tabular} & $\begin{array}{ll}x & x \\
& x\end{array}$ & $\begin{array}{ll}\mathrm{x} & \mathrm{x} \\
& \mathrm{x}\end{array}$ & \begin{tabular}{|l}
$x$ \\
$x$
\end{tabular} & & $x$ & & $\begin{array}{l}\mathrm{x} \\
\mathrm{x} \\
\mathrm{x}\end{array}$ & $\begin{array}{r}\mathrm{x} \\
\mathrm{x} \\
\mathrm{x}\end{array}$ & $\begin{array}{|ll|}x & \\
x & x \\
x & x\end{array}$ & $x$ & $\begin{array}{ll}x & \\
x & x\end{array}$ & $\mathrm{x}$ & $\mathrm{x}$ & $x^{x}$ \\
\hline & & $\begin{array}{l}\text { O. glomerosa } \\
\text { curva }\end{array}$ & $\begin{array}{l}20, \mathrm{CC} \\
21, \mathrm{CC}\end{array}$ & $\begin{array}{l}\mathrm{P} \\
\mathrm{P}\end{array}$ & $\begin{array}{l}x \\
x\end{array}$ & $\begin{array}{ll}x & x \\
x & \end{array}$ & $\mathrm{x} \quad \mathrm{x}$ & $x$ & $\mathrm{x} x$ & $x \quad x$ & & & & & & & & & \\
\hline & early & G. miozea & $\begin{array}{l}22, \mathrm{CC} \\
23, \mathrm{CC} \\
24, \mathrm{CC}\end{array}$ & \begin{tabular}{l|}
$\mathrm{P}$ \\
$\mathrm{P}$ \\
$\mathrm{P}$ \\
\end{tabular} & \begin{tabular}{|l|}
$x$ \\
$x$ \\
$x$
\end{tabular} & $\begin{array}{l}x \\
x \\
x\end{array}$ & & & & & & & & & & & & & \\
\hline
\end{tabular}


Table 8. (Continued).

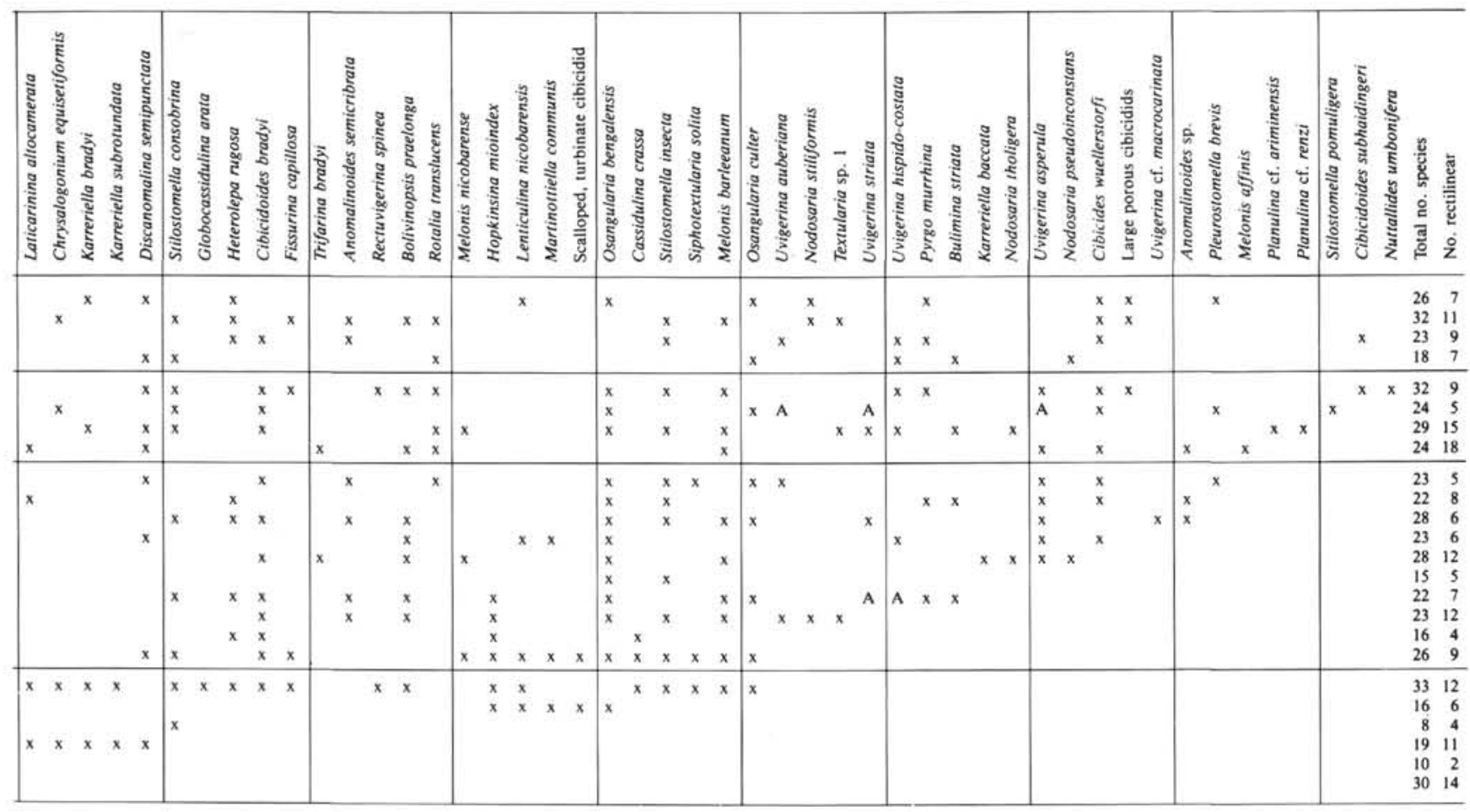

Table 9. (Continued).

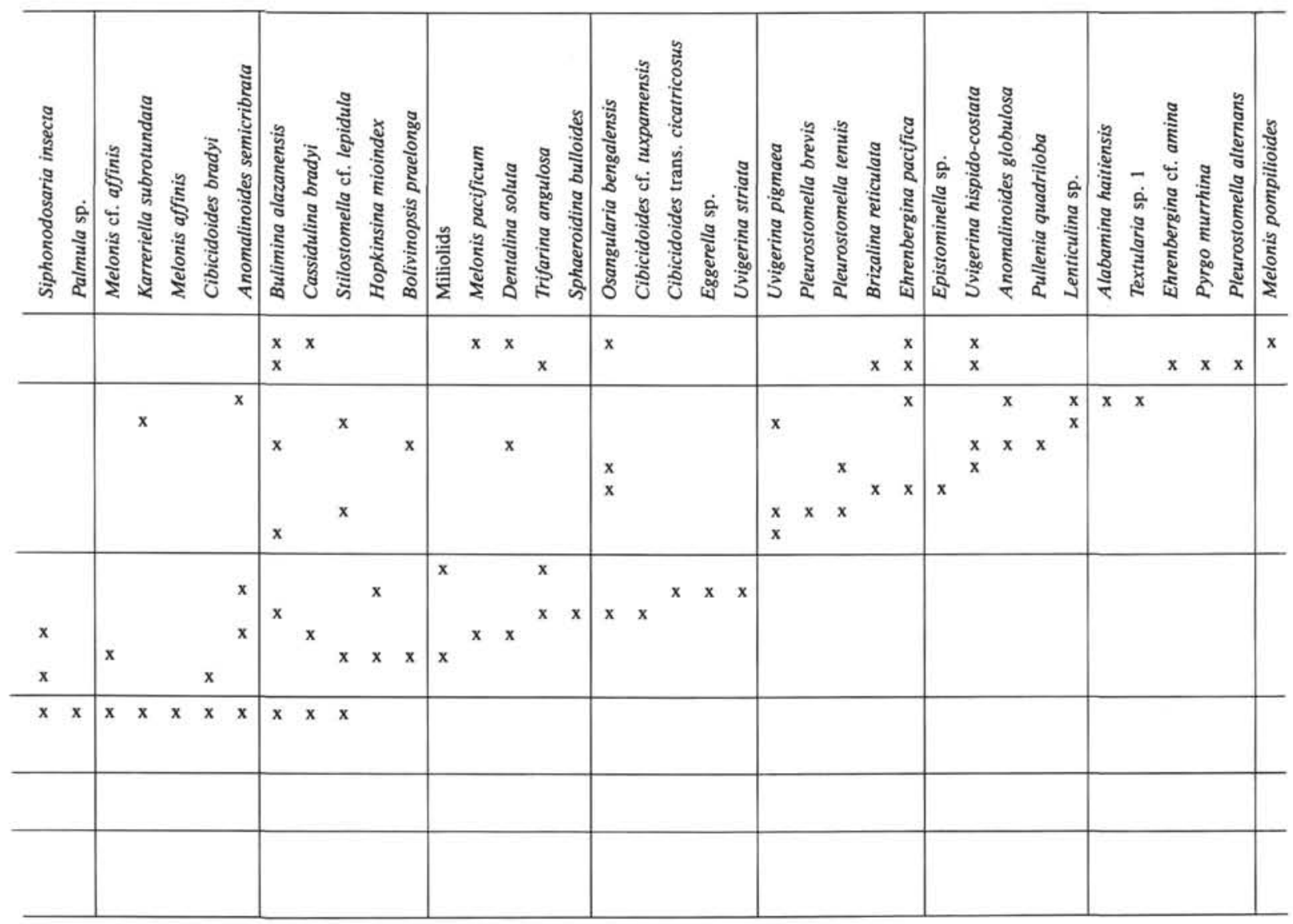




\section{A. BOERSMA}

Table 10. Benthic foraminifers, Hole 591, late Miocene.

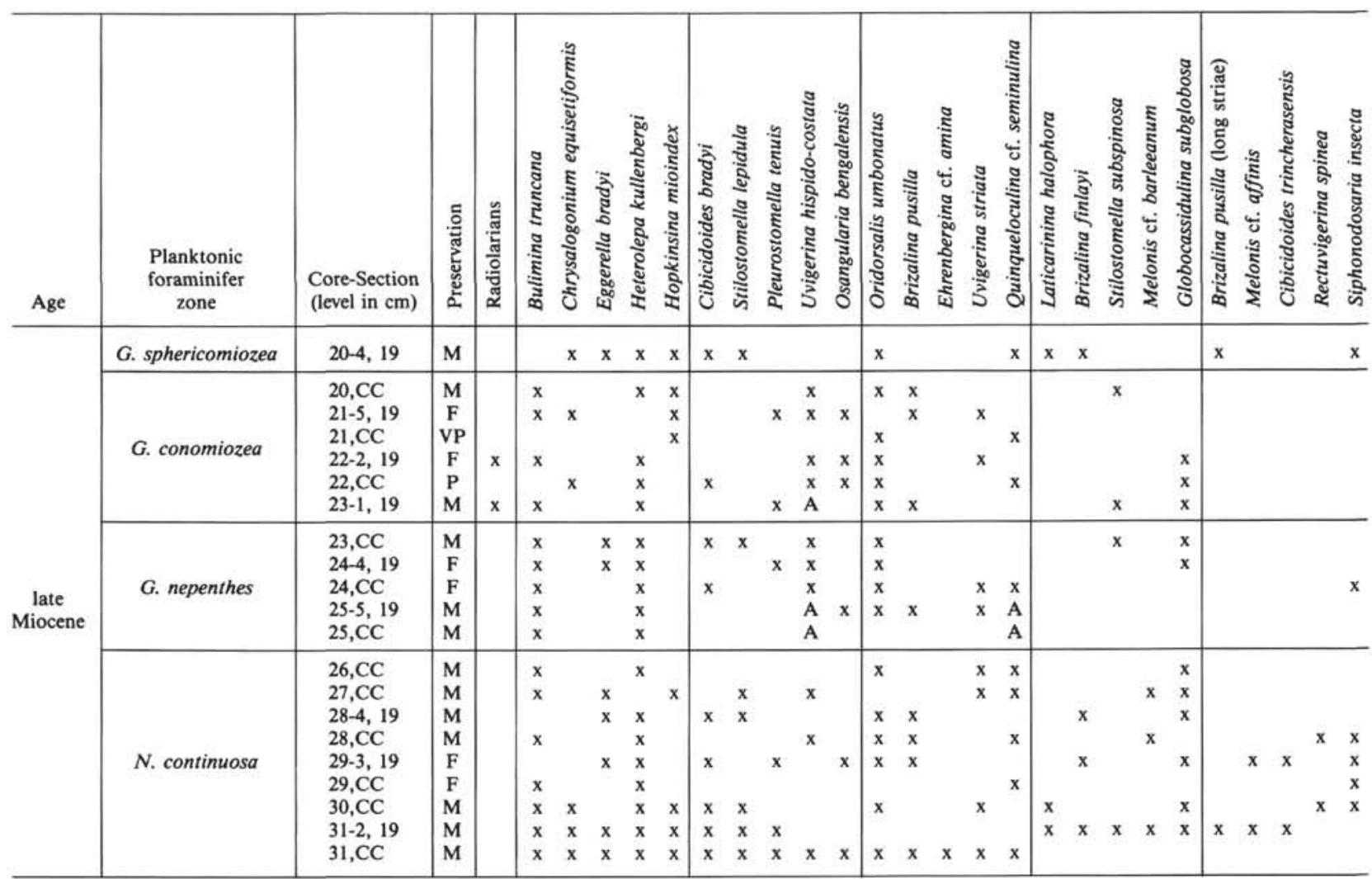

Note: Total no. of species, 65 .

Table 11. Benthic foraminifers, Hole 591, Pliocene.

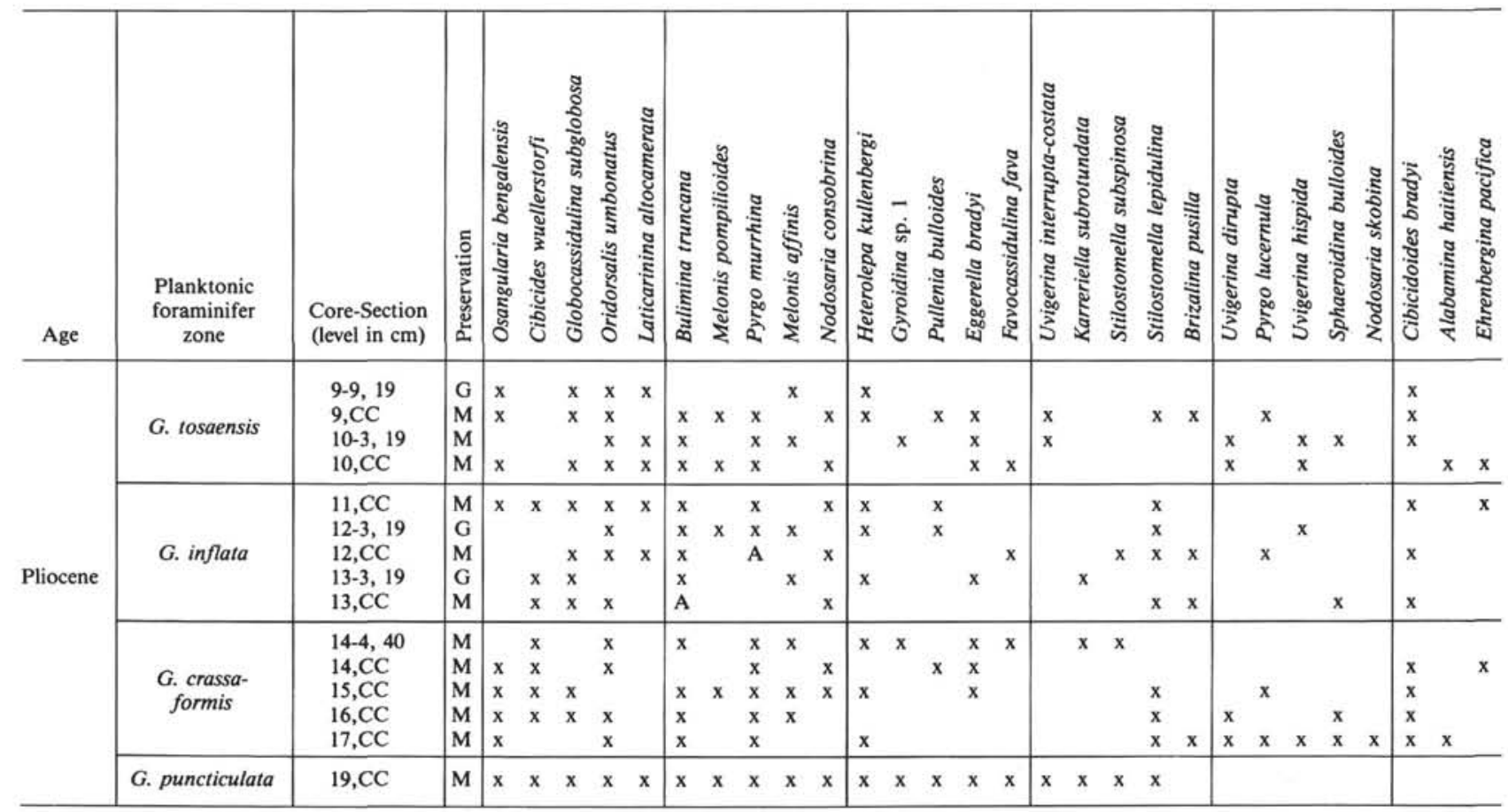


Table 10. (Continued).

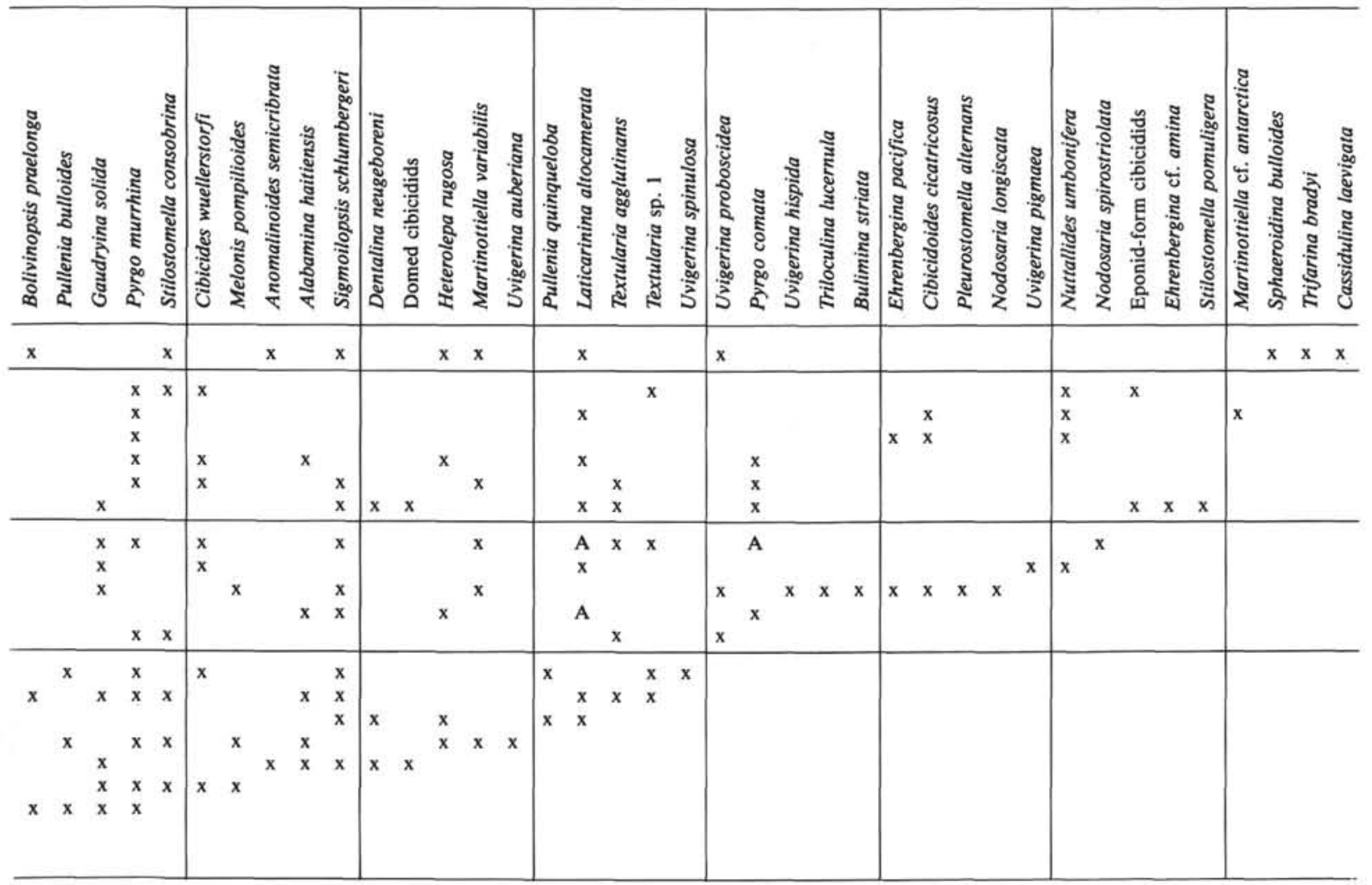

Table 11. (Continued).

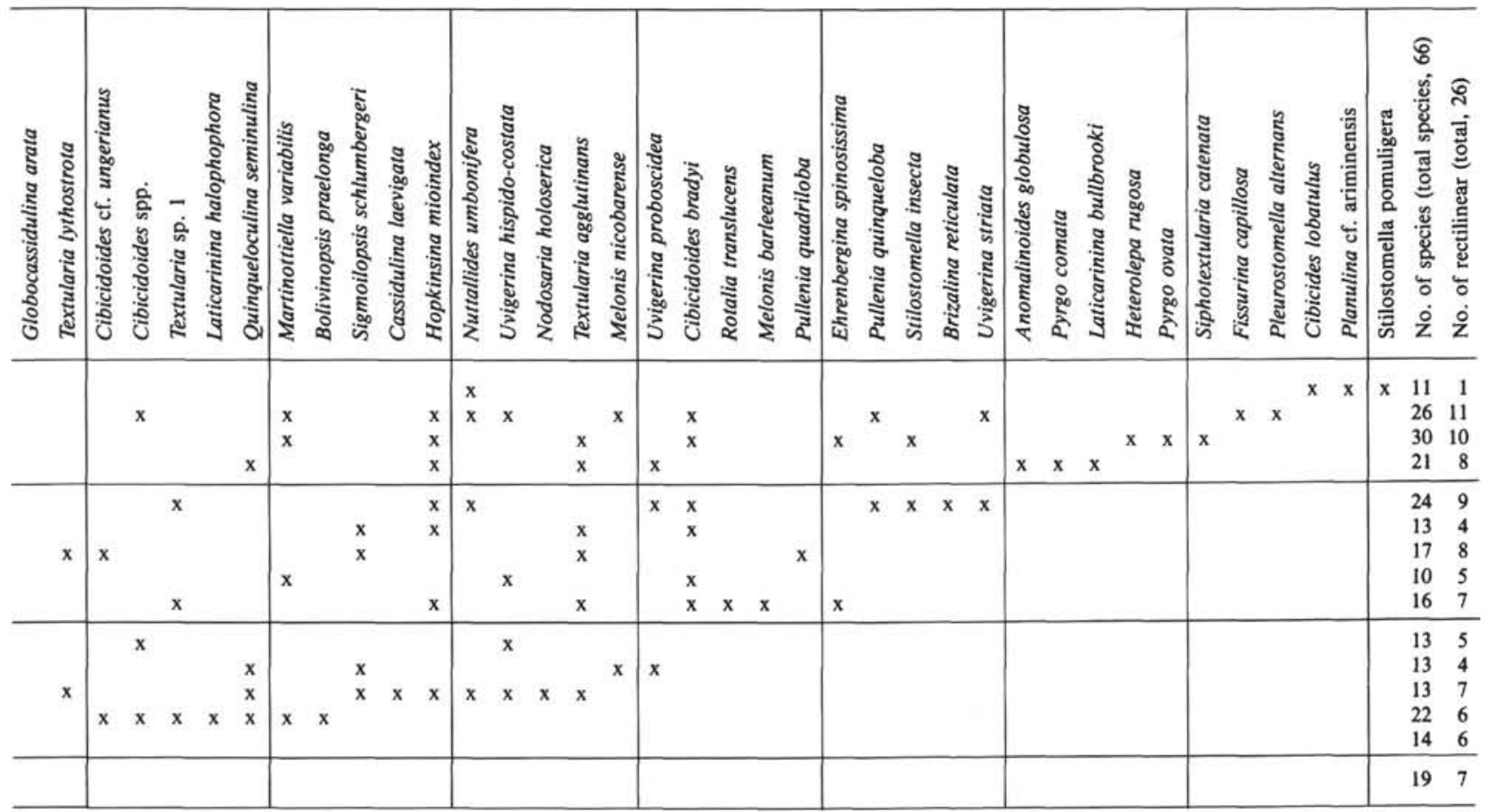


Table 12. Benthic foraminifers, Hole 592, Eocene-Oligocene.

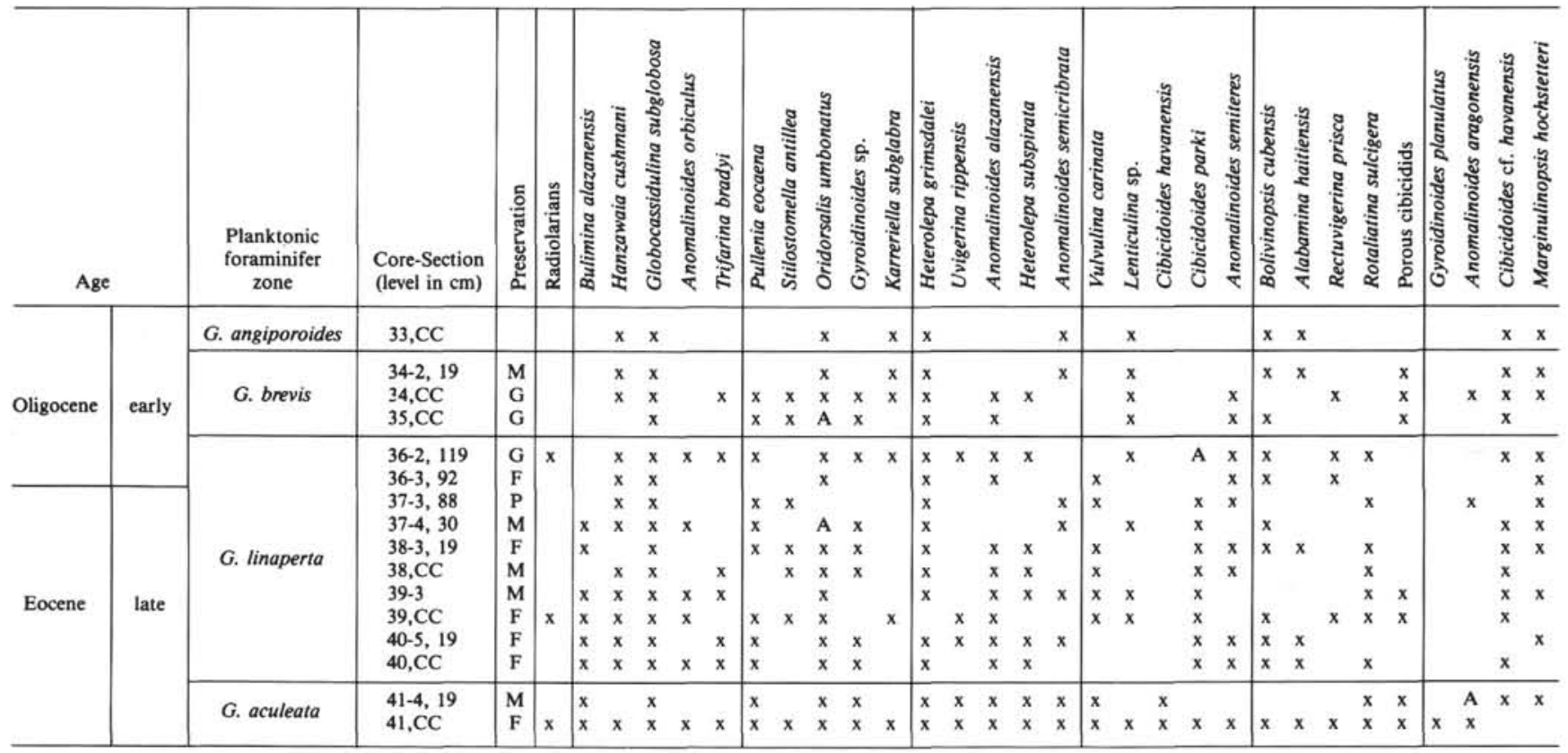

Note: Total no. of species, 75 .

Table 13. Benthic foraminifers, Hole 592, early-mid Miocene.

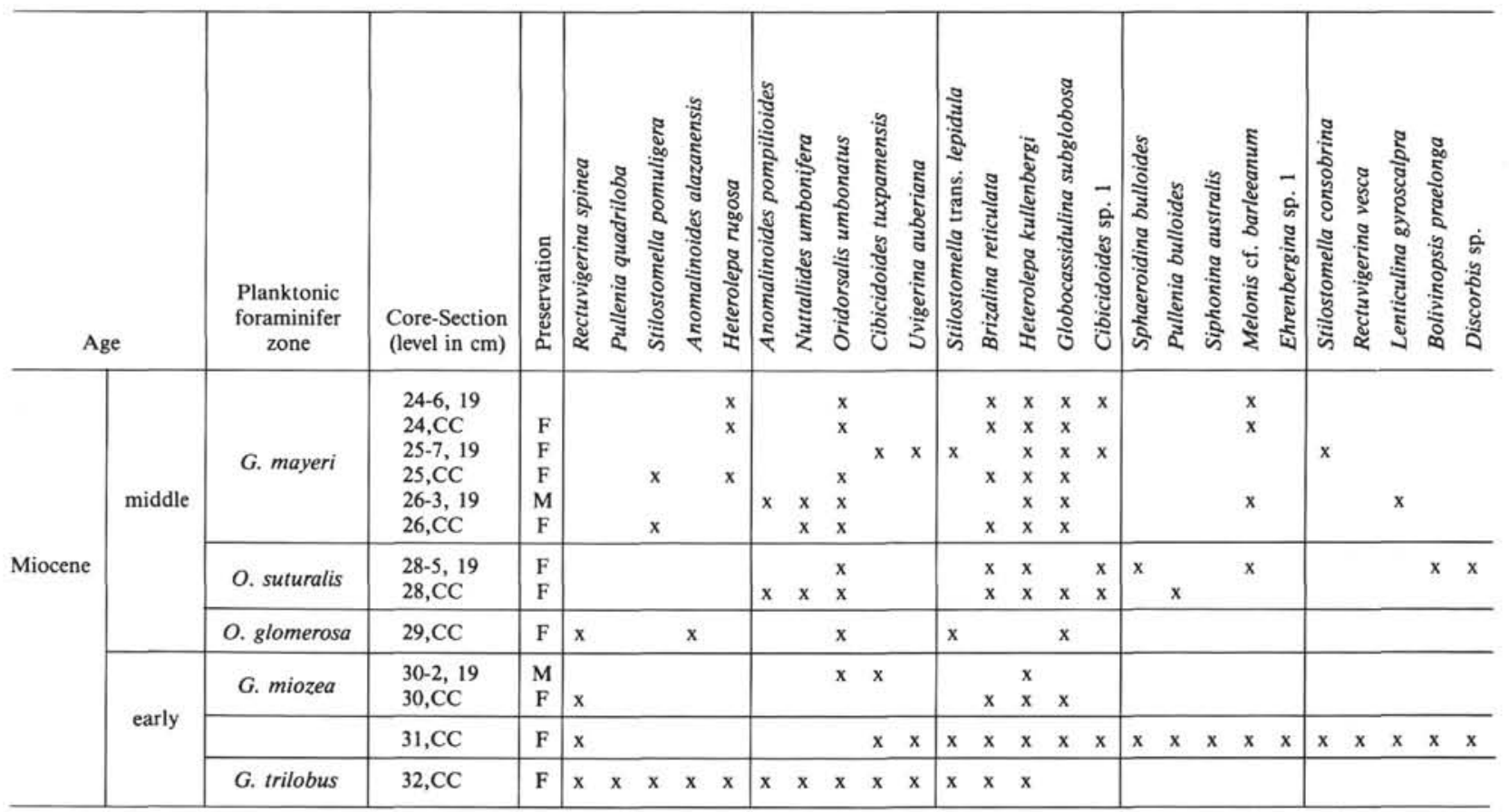

Note: Total no. of species, 67. 
Table 12. (Continued).

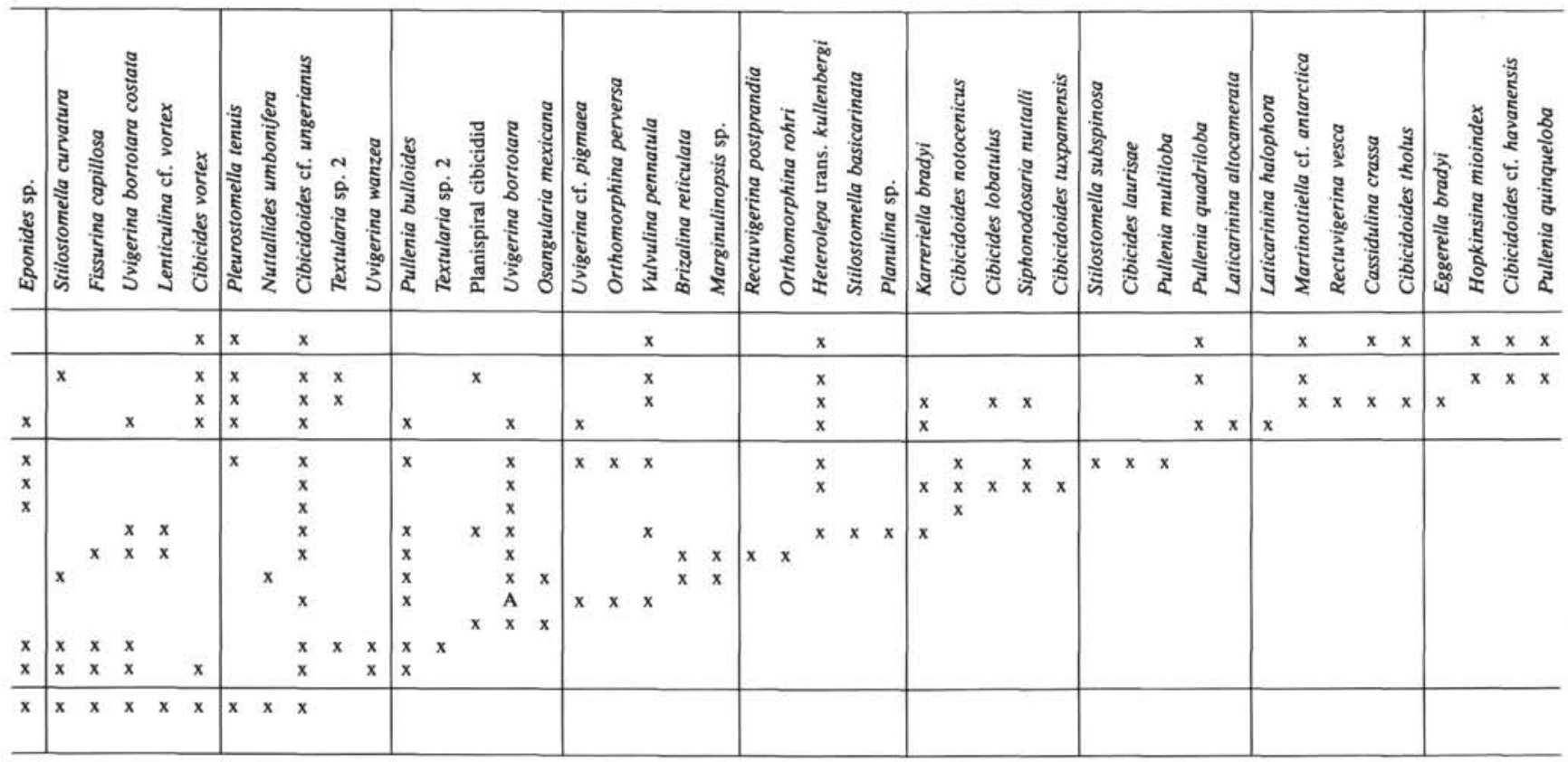

Table 13. (Continued).

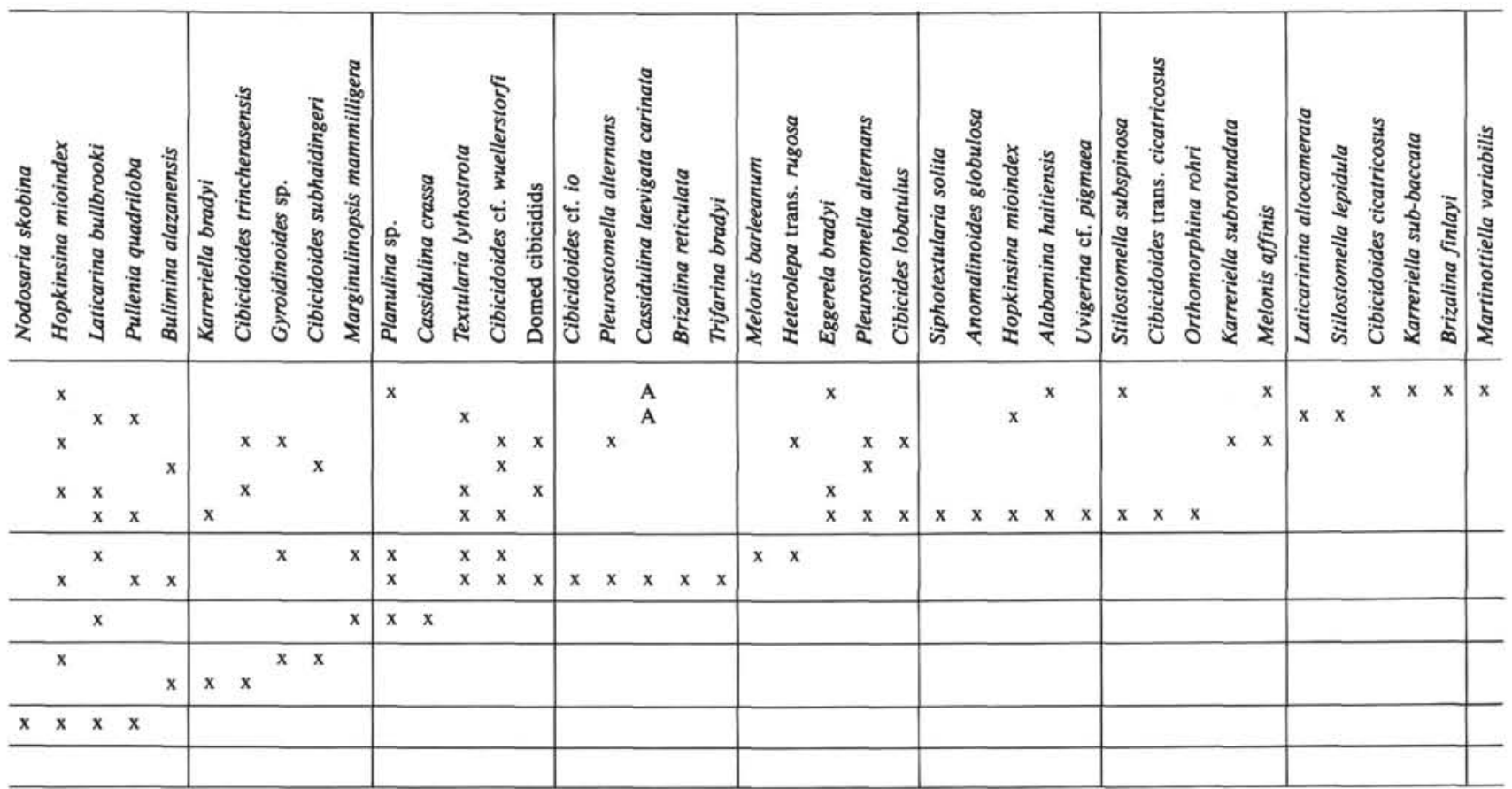


Table 14. Benthic foraminifers, Hole 592, late Miocene.

\begin{tabular}{|c|c|c|c|c|c|c|c|c|c|c|c|c|c|c|c|c|c|c|c|c|c|c|c|c|c|c|c|c|c|}
\hline Age & $\begin{array}{l}\text { Planktonic } \\
\text { foraminifer } \\
\text { zone }\end{array}$ & $\begin{array}{l}\text { Core-Section } \\
\text { (level in } \mathrm{cm} \text { ) }\end{array}$ & 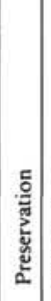 & 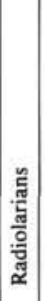 & 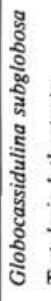 & 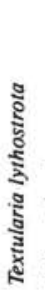 & 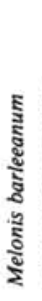 & 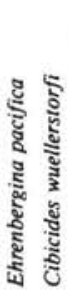 & 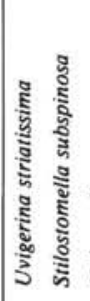 & 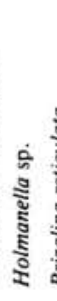 & 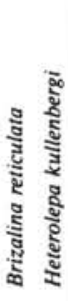 & 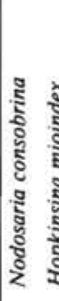 & 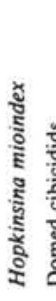 & 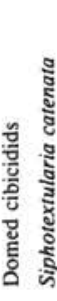 & 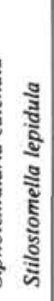 & 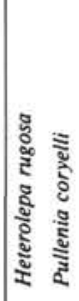 & 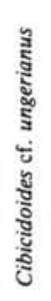 & 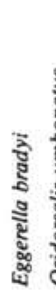 & & 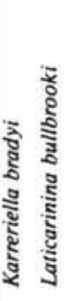 & 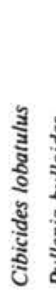 & 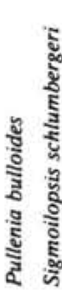 & 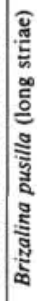 & $\begin{array}{l}\text { हूँ } \\
\text { हूँ } \\
\text { हूँ } \\
\text { हूँ }\end{array}$ & 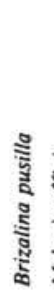 & 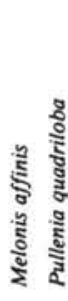 & 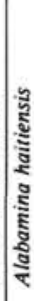 & 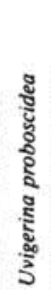 & 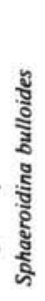 \\
\hline \multirow{2}{*}{$\begin{array}{c}\text { late } \\
\text { Miocene }\end{array}$} & G. conomiozea & $\begin{array}{l}12, \mathrm{CC} \\
13-2,19 \\
13, \mathrm{CC} \\
14-2,1 \\
14, \mathrm{CC} \\
15-2,19 \\
15, \mathrm{CC} \\
16, \mathrm{CC} \\
17-2,19 \\
17, \mathrm{CC}\end{array}$ & \begin{tabular}{l|l}
$M$ & \\
$M$ & \\
$M$ & \\
$M$ & \\
$M$ & \\
$M$ & \\
$M$ & \\
$M$ & \\
$M$ &
\end{tabular} & & $\begin{array}{l}x \\
x \\
x \\
x \\
x\end{array}$ & $\begin{array}{l}x \\
x \\
x \\
x \\
x\end{array}$ & $\begin{array}{l}x \\
x \\
x\end{array}$ & 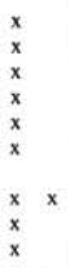 & & & $\begin{array}{l}x \\
x \\
x \\
x \\
x \\
x\end{array}$ & $\begin{array}{ll}x & x \\
x & x \\
& x \\
x & x \\
x & x \\
x & x \\
& x \\
& x \\
x & x \\
& x\end{array}$ & $\begin{array}{l}x \\
x \\
x \\
x \\
x \\
x \\
x \\
x \\
x \\
x \\
x\end{array}$ & & $\begin{array}{l}x \\
x\end{array}$ & $\begin{array}{l}\mathrm{x} \\
\mathrm{x} \\
\mathrm{x} \\
\\
\mathrm{x} \\
\mathrm{x} \\
\mathrm{x} \\
\mathrm{x} \\
\mathrm{x}\end{array}$ & $\begin{array}{l}x \\
x \\
x \\
x \\
x \\
x \\
x \\
x\end{array}$ & 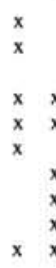 & $\begin{array}{l}x \\
x \\
x \\
x \\
x \\
x\end{array}$ & $\mathrm{x}$ & $\begin{array}{ll}\mathrm{x} & \\
\mathrm{x} & \\
& x \\
\mathrm{x} & \\
& x \\
\mathrm{x} & \\
\mathrm{x} & \mathrm{x}\end{array}$ & $\begin{array}{rr} & x \\
& x \\
x & x \\
x & \\
x & x \\
& x \\
x & x\end{array}$ & $\begin{array}{l}x \\
x\end{array}$ & $x$ & $\begin{array}{l}x \\
x\end{array}$ & $\begin{array}{ll}x & \\
& \\
& \end{array}$ & $x$ & $\begin{array}{l}\mathrm{x} \\
\mathrm{x} \\
\mathrm{x} \\
\mathrm{x} \\
\mathrm{x}\end{array}$ & $\begin{array}{l}\mathrm{x} \\
\mathrm{x}\end{array}$ \\
\hline & N. continuosa & $\begin{array}{l}22-4,19 \\
22, \mathrm{CC} \\
23-2,19\end{array}$ & $\begin{array}{l}\mathrm{M} \\
\mathrm{M} \\
\mathrm{M}\end{array}$ & & $\begin{array}{l}\mathrm{x} \\
\mathrm{x} \\
\mathrm{x}\end{array}$ & $x$ & $\begin{array}{l}\mathrm{x} \\
\mathrm{x}\end{array}$ & $x \quad x$ & $\begin{array}{r}\mathrm{x} \\
\mathrm{x} \\
\mathrm{x} \\
\mathrm{x}\end{array}$ & $\times$ & $\begin{array}{ll}x & \\
& x \\
x & x\end{array}$ & $x$ & $\begin{array}{ll}x & \\
x & x\end{array}$ & $\mathrm{x}$ & $\begin{array}{l}x \\
x \\
x\end{array}$ & $x \quad x$ & $\mathrm{x}$ & & & & $x \quad x$ & $x \quad x$ & $x$ & $\mathrm{x}$ & $x$ & $x \quad x$ & $x$ & & \\
\hline
\end{tabular}

Table 15. Benthic foraminifers, Hole 592, Pliocene.

\begin{tabular}{|c|c|c|c|c|c|c|c|c|c|c|c|c|c|c|c|c|c|c|c|c|c|c|c|c|c|c|c|c|c|c|c|}
\hline Age & $\begin{array}{c}\text { Planktonic } \\
\text { foraminifer } \\
\text { zone }\end{array}$ & $\begin{array}{l}\text { Core-Section } \\
\text { (level in cm) }\end{array}$ & 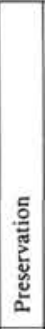 & 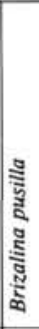 & 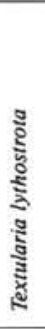 & 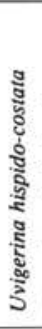 & 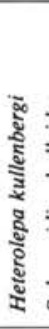 & 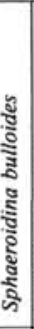 & 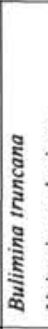 & 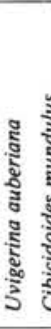 & & 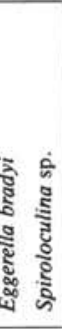 & 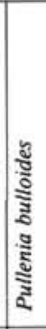 & 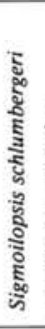 & 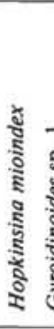 & 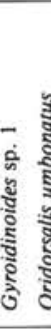 & & 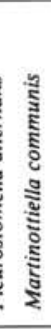 & 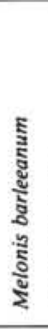 & 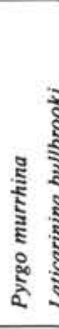 & & ฐ & & 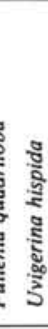 & 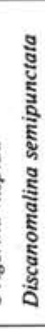 & 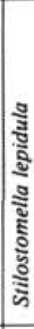 & 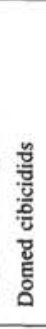 & 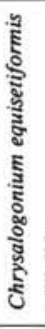 & 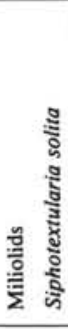 & & 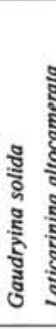 \\
\hline \multirow{5}{*}{ Pliocene } & $\begin{array}{l}\text { G. truncatulinoides } \\
-G \text {. tosaensis }\end{array}$ & $3, \mathrm{CC}$ & G & & $\mathrm{x}$ & $x$ & $\mathrm{x}$ & $x$ & & & & & & & & $\mathrm{x}$ & & & $x$ & & & & & & & $x$ & & & & $x$ & \\
\hline & $\begin{array}{c}G . \\
\text { inflata }\end{array}$ & $\begin{array}{l}4-6,35 \\
4, C C \\
5, C C \\
6-2,19 \\
6, C C \\
7, C C\end{array}$ & \begin{tabular}{l|}
$G$ \\
$G$ \\
$G$ \\
$G$ \\
$G$ \\
$G$ \\
\end{tabular} & $\begin{array}{l}x \\
x \\
x \\
x \\
x \\
x\end{array}$ & $\begin{array}{l}\mathrm{x} \\
\mathrm{x}\end{array}$ & $\begin{array}{l}x \\
x \\
x\end{array}$ & $\begin{array}{l}x \\
x \\
x\end{array}$ & $\begin{array}{l}\mathrm{x} \\
\mathrm{x} \\
\mathrm{x} \\
\mathrm{x} \\
\mathrm{x} \\
\mathrm{x}\end{array}$ & & $\mathrm{x}$ & $\begin{array}{ll}x & \\
x & \\
x & \\
x & x \\
x & \end{array}$ & $\begin{array}{r}x \\
x \\
x\end{array}$ & $\begin{array}{l}x \\
x \\
x\end{array}$ & $\begin{array}{l}x \\
x \\
x \\
x \\
x\end{array}$ & & $\begin{array}{ll}x & x \\
& x\end{array}$ & $x$ & $x$ & $\begin{array}{l}x \\
x \\
x \\
x \\
x\end{array}$ & $\begin{array}{l} \\
x \\
x\end{array}$ & $x$ & $\mathrm{x}$ & $\begin{array}{ll}x & x \\
x & \end{array}$ & & $\begin{array}{l}x \\
x \\
x \\
x \\
x\end{array}$ & $\begin{array}{l}x \\
x \\
x \\
x\end{array}$ & & & & $\begin{array}{l}x \\
x \\
x \\
x\end{array}$ & $\begin{array}{l}x \\
x \\
x \\
x \\
x\end{array}$ \\
\hline & $\begin{array}{c}G . \\
\text { crassaformis }\end{array}$ & $\begin{array}{l}8-6,19 \\
8, C C \\
9-3,19 \\
9, C C\end{array}$ & $\begin{array}{l}\mathrm{G} \\
\mathrm{G} \\
\mathrm{G} \\
\mathrm{G} \\
\end{array}$ & x & $\begin{array}{l}x \\
x \\
\end{array}$ & $\begin{array}{l}x \\
x \\
x\end{array}$ & $\begin{array}{l}\mathrm{x} \\
\mathrm{x}\end{array}$ & $\begin{array}{l}\mathrm{x} \\
\mathrm{x} \\
\mathrm{x} \\
\end{array}$ & $x$ & $\begin{array}{l}x^{\prime} \\
x\end{array}$ & $\begin{array}{ll}x & x \\
x & \\
x\end{array}$ & $\begin{array}{l}x \\
x \\
x\end{array}$ & $\begin{array}{l}x \\
x \\
x\end{array}$ & $\begin{array}{l}x \\
x \\
x \\
x \\
\end{array}$ & $\begin{array}{l}x \\
x \\
\end{array}$ & $\begin{array}{ll}x & x \\
& x\end{array}$ & $x$ & & $\begin{array}{l}x \\
x \\
x \\
\end{array}$ & $x^{\prime}$ & $x$ & & $\begin{array}{ll}x & x \\
x & \end{array}$ & $x$ & $\begin{array}{l}\mathrm{x} \\
\mathrm{x} \\
\mathrm{x} \\
\end{array}$ & \begin{tabular}{|l|}
$x$ \\
$x$ \\
$x$ \\
$x$ \\
\end{tabular} & & & $x^{x}$ & $\begin{array}{l}x \\
x \\
x\end{array}$ & $\begin{array}{l}x \\
x \\
x \\
\end{array}$ \\
\hline & G. puncticulata & $10, \mathrm{CC}$ & G & $x$ & & & $\mathrm{x}$ & $\mathrm{x}$ & & & & & & & & $x$ & & $x$ & & $\mathrm{x}$ & $x$ & & & $\mathrm{x}$ & $\mathrm{x}$ & $x$ & & & $\mathrm{x}$ & & $x$ \\
\hline & $\begin{array}{c}\text { G. } \\
\text { sphericomiozea }\end{array}$ & $\begin{array}{l}11-4,19 \\
11, \mathrm{CC}\end{array}$ & $\begin{array}{l}G \\
G\end{array}$ & $\begin{array}{l}x \\
x\end{array}$ & $\begin{array}{l}\mathrm{x} \\
\mathrm{x}\end{array}$ & $x$ & $\begin{array}{l}x \\
x\end{array}$ & $\mathrm{x}$ & $x$ & $\begin{array}{ll}x & x \\
x & x\end{array}$ & $\begin{array}{l}x, \\
x\end{array}$ & $\begin{array}{ll}\mathrm{x} & \\
\mathrm{x} & \mathrm{x}\end{array}$ & $\mathrm{x}$ & $\begin{array}{l}\mathrm{x} \\
\mathrm{x}\end{array}$ & $\mathrm{x}$ & $\begin{array}{ll}x & \\
x & x\end{array}$ & , & $\begin{array}{l}\mathrm{x} \\
\mathrm{x}\end{array}$ & $\begin{array}{l}\mathrm{x} \\
\mathrm{x}\end{array}$ & $\mathrm{x}$ & $x$ & $\begin{array}{l}\mathrm{x} \\
\mathrm{x}\end{array}$ & $\begin{array}{ll}x & x\end{array}$ & $x \quad x$ & $\begin{array}{l}\mathrm{x} \\
\mathrm{x}\end{array}$ & $\begin{array}{l}x \\
x\end{array}$ & $x$ & $\mathrm{x}$ & $x \quad x$ & $\begin{array}{l}\mathrm{x} \\
\mathrm{x}\end{array}$ & $\begin{array}{l}\mathrm{x} \\
\mathrm{x}\end{array}$ \\
\hline
\end{tabular}


Table 14. (Continued).

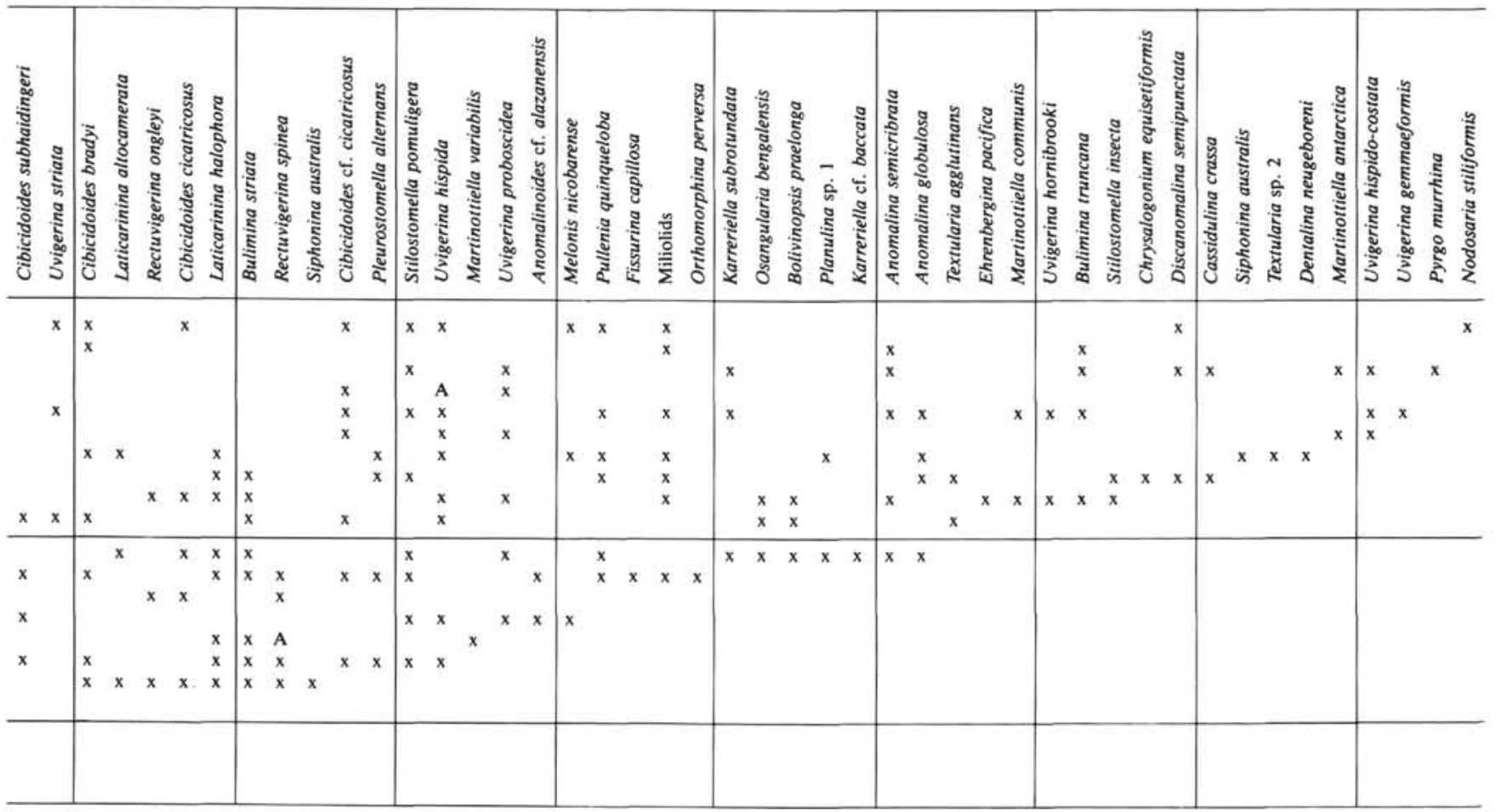

Table 15. (Continued).

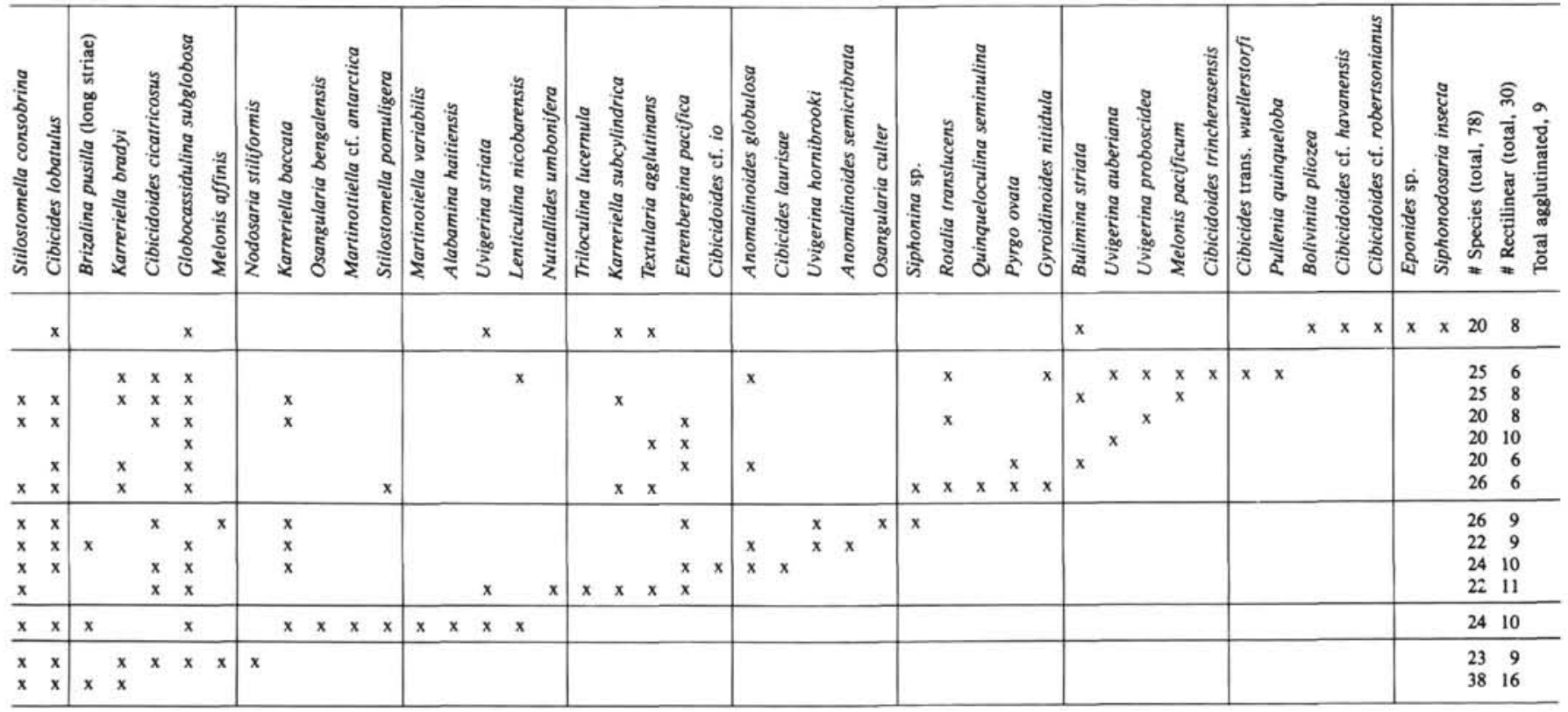


Table 16. Benthic foraminifers, Hole 593, Eocene-Oligocene.

\begin{tabular}{|c|c|c|c|c|c|c|c|c|c|c|c|c|c|c|c|c|c|c|c|c|c|c|c|c|c|c|c|c|c|c|c|}
\hline Age & $\begin{array}{c}\text { Planktonic } \\
\text { foraminifer } \\
\text { zone }\end{array}$ & $\begin{array}{l}\text { Core-Section } \\
\text { (level in } \mathrm{cm} \text { ) }\end{array}$ & 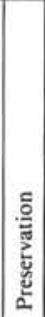 & 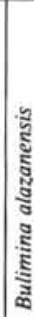 & 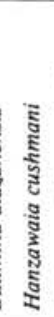 & 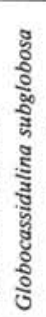 & 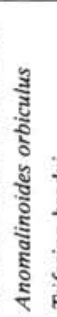 & 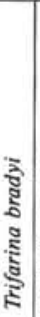 & 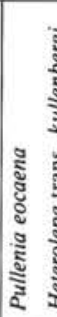 & 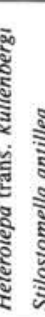 & 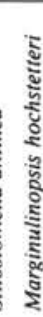 & 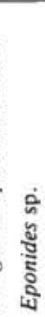 & 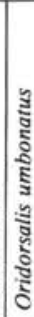 & 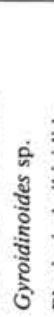 & 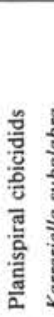 & 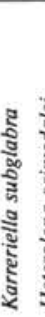 & 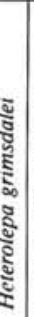 & 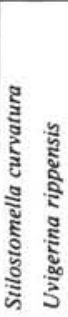 & 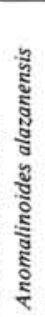 & 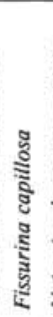 & 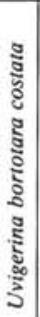 & 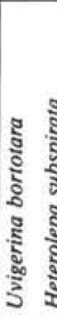 & 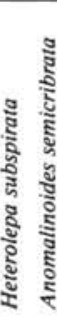 & 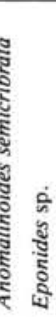 & 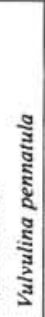 & 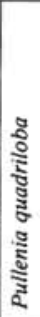 & 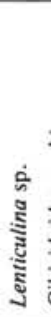 & 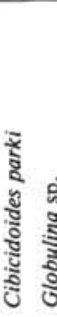 & 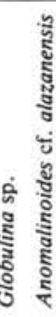 & 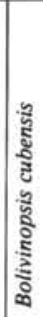 & 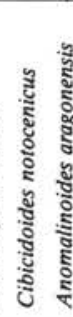 \\
\hline \multirow{3}{*}{ Oligocene } & G. euaperta & $\begin{array}{l}50-1,19 \\
50-3,19 \\
50-5,19 \\
50, C C\end{array}$ & \begin{tabular}{|c|}
$\mathrm{M}$ \\
$\mathrm{F}$ \\
$\mathrm{F}$ \\
$\mathrm{M}$ \\
\end{tabular} & $x$ & & $\begin{array}{l}\mathrm{x} \\
\mathrm{x} \\
\mathrm{x}\end{array}$ & $\mathrm{x}$ & & $\begin{array}{l}x \\
x\end{array}$ & x & & & $\begin{array}{l}\mathrm{x} \\
\mathrm{x}\end{array}$ & . & $x$ & & $\begin{array}{l}x \\
x\end{array}$ & & $\mathrm{x}$ & & & & & & & $\begin{array}{l}\mathrm{x} \\
\mathrm{x} \\
\mathrm{x} \\
\end{array}$ & & & & & \\
\hline & G. angiporoides & $\begin{array}{l}52-3,96 \\
52, \mathrm{CC} \\
53-3,19 \\
53, \mathrm{CC} \\
54, \mathrm{CC} \\
55-2,19 \\
55, \mathrm{CC}\end{array}$ & \begin{tabular}{|c|}
$\mathrm{F}$ \\
$\mathrm{M}$ \\
$\mathrm{F}$ \\
$\mathrm{G}$ \\
$\mathrm{M}$ \\
$\mathrm{G}$ \\
$\mathrm{M}$
\end{tabular} & $\begin{array}{l}x \\
x \\
x \\
x \\
x\end{array}$ & $\begin{array}{l}\mathrm{x} \\
\mathrm{x} \\
\mathrm{x}\end{array}$ & $\begin{array}{l}x \\
x \\
x \\
x \\
x \\
x\end{array}$ & $\begin{array}{l}x \\
x \\
x\end{array}$ & $\begin{array}{l}x \\
x\end{array}$ & $\mathrm{x}$ & $\begin{array}{ll} & x \\
x & \\
x & \\
& x \\
x & x \\
& x \\
x & x\end{array}$ & $\begin{array}{l}x \\
x\end{array}$ & $\begin{array}{l}\mathrm{x} \\
\mathrm{x}\end{array}$ & \begin{tabular}{|l}
$\mathrm{x}$ \\
$\mathrm{x}$ \\
$\mathrm{x}$ \\
$\mathrm{x}$ \\
$\mathrm{x}$
\end{tabular} & $\begin{array}{l}x \\
x \\
x\end{array}$ & & & $\begin{array}{l}x \\
x \\
x \\
x \\
x\end{array}$ & $\begin{array}{l}x \\
x\end{array}$ & $\begin{array}{l}\mathrm{x} \\
\mathrm{x} \\
\mathrm{x}\end{array}$ & & & & $\mathrm{x}$ & $x$ & & $\begin{array}{l}\mathrm{x} \\
\mathrm{x}\end{array}$ & $\mathrm{x}$ & & & $\begin{array}{l}x \\
x \\
x \\
x \\
x \\
x\end{array}$ & $\begin{array}{l}\mathrm{x} \\
\mathrm{x}\end{array}$ \\
\hline & G. linaperta & $\begin{array}{l}58-1,19 \\
58-2,19 \\
60-1,7 \\
60, C C\end{array}$ & \begin{tabular}{|c|}
$\mathrm{F}$ \\
$\mathrm{M}$ \\
$\mathrm{F}$ \\
$\mathrm{G}$
\end{tabular} & $\begin{array}{l}x \\
x\end{array}$ & $\begin{array}{l}\mathrm{x} \\
\mathrm{x} \\
\mathrm{x}\end{array}$ & $\begin{array}{l}x \\
x \\
A \\
A\end{array}$ & $\begin{array}{l}x \\
x \\
x \\
x\end{array}$ & $\begin{array}{l}\mathrm{x} \\
\mathrm{x} \\
\mathrm{x}\end{array}$ & $\begin{array}{l}x \quad x \\
x \quad x \\
x\end{array}$ & $\begin{array}{ll}x & x \\
& x \\
x & x \\
x & x\end{array}$ & $\begin{array}{l}x \\
x\end{array}$ & $\mathrm{x}$ & $\begin{array}{l}x \\
x \\
x \\
x\end{array}$ & $\begin{array}{l}\mathrm{x} \\
\mathrm{x} \\
\mathrm{x}\end{array}$ & $\begin{array}{l}x \\
x \\
x\end{array}$ & $\begin{array}{l}\mathrm{x} \\
\mathrm{x} \\
\mathrm{x}\end{array}$ & $\begin{array}{l}x \\
x\end{array}$ & $\begin{array}{ll} & x \\
x & \\
x & \\
x & x\end{array}$ & $\begin{array}{l}x \\
x \\
x \\
x\end{array}$ & $x$ & $\begin{array}{l}x \\
x \\
x \\
x\end{array}$ & $\begin{array}{ll}x & x \\
x & x \\
x & x\end{array}$ & $\begin{array}{ll}x & \\
x & \\
x & x\end{array}$ & $\begin{array}{r}x \\
x \quad x\end{array}$ & $\mathrm{x}$ & $\begin{array}{l}x \\
x \\
x \\
x\end{array}$ & $\begin{array}{l}x \\
x \\
x\end{array}$ & $\begin{array}{ll}x & \\
x & x\end{array}$ & $\begin{array}{r}x \\
x \quad x\end{array}$ & $\begin{array}{l}x \\
x \\
x\end{array}$ & $x \quad x$ \\
\hline
\end{tabular}

Note: Total no. of species, 79.

Table 17. Benthic foraminifers, Hole 593, early Miocene.

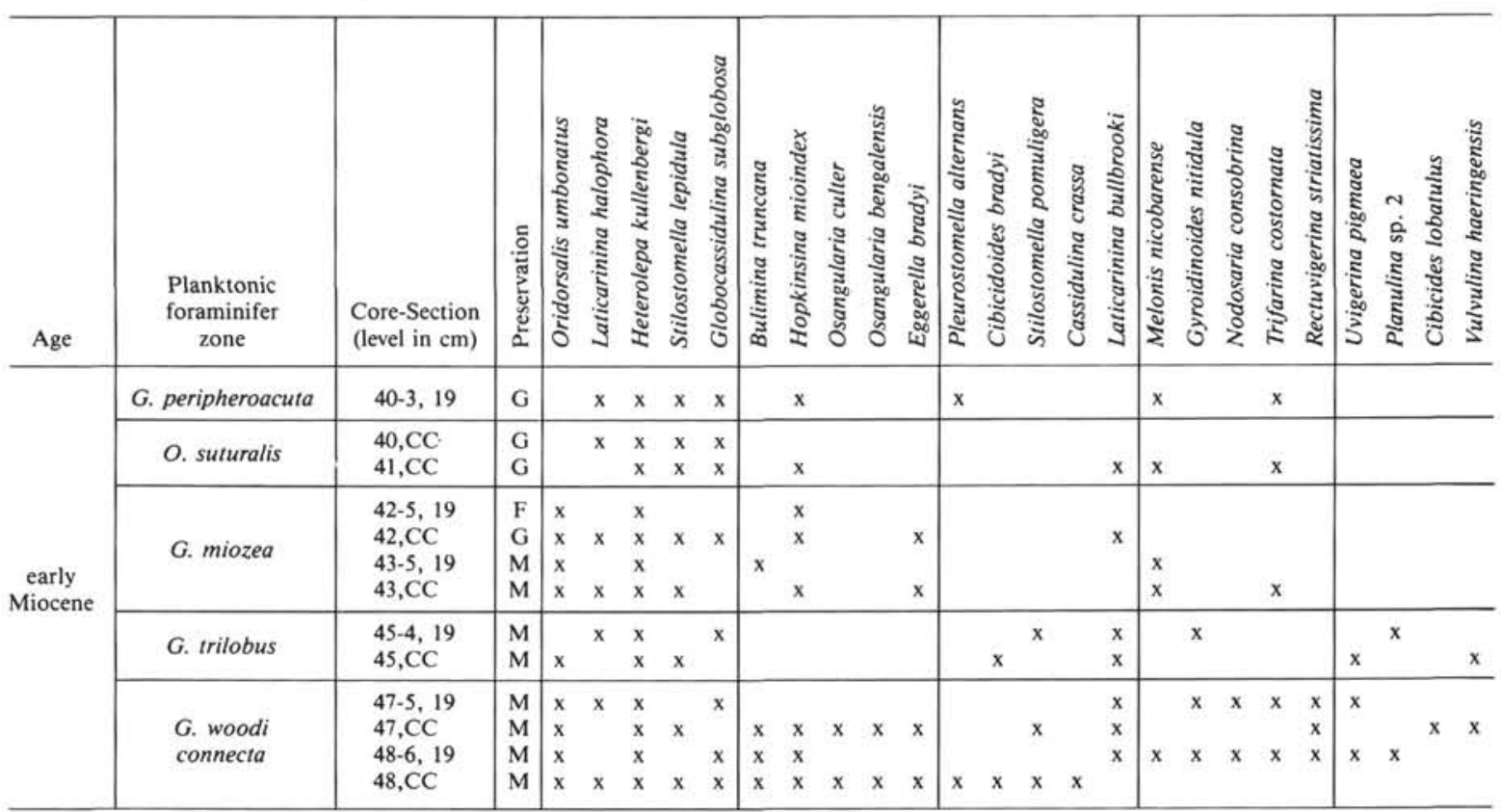

Note: Total no. of species, 64 . 
Table 16. (Continued).

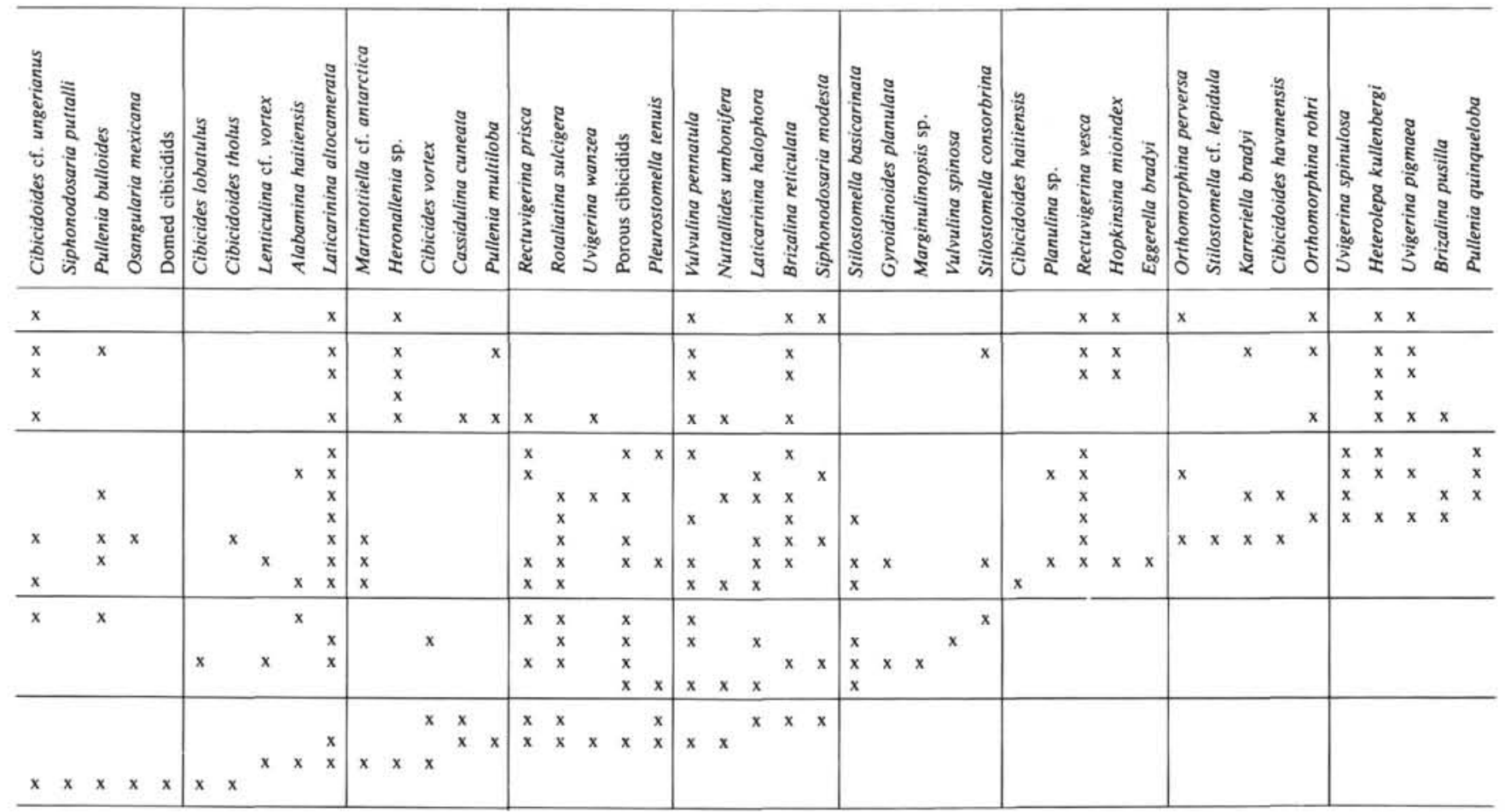

Table 17. (Continued).

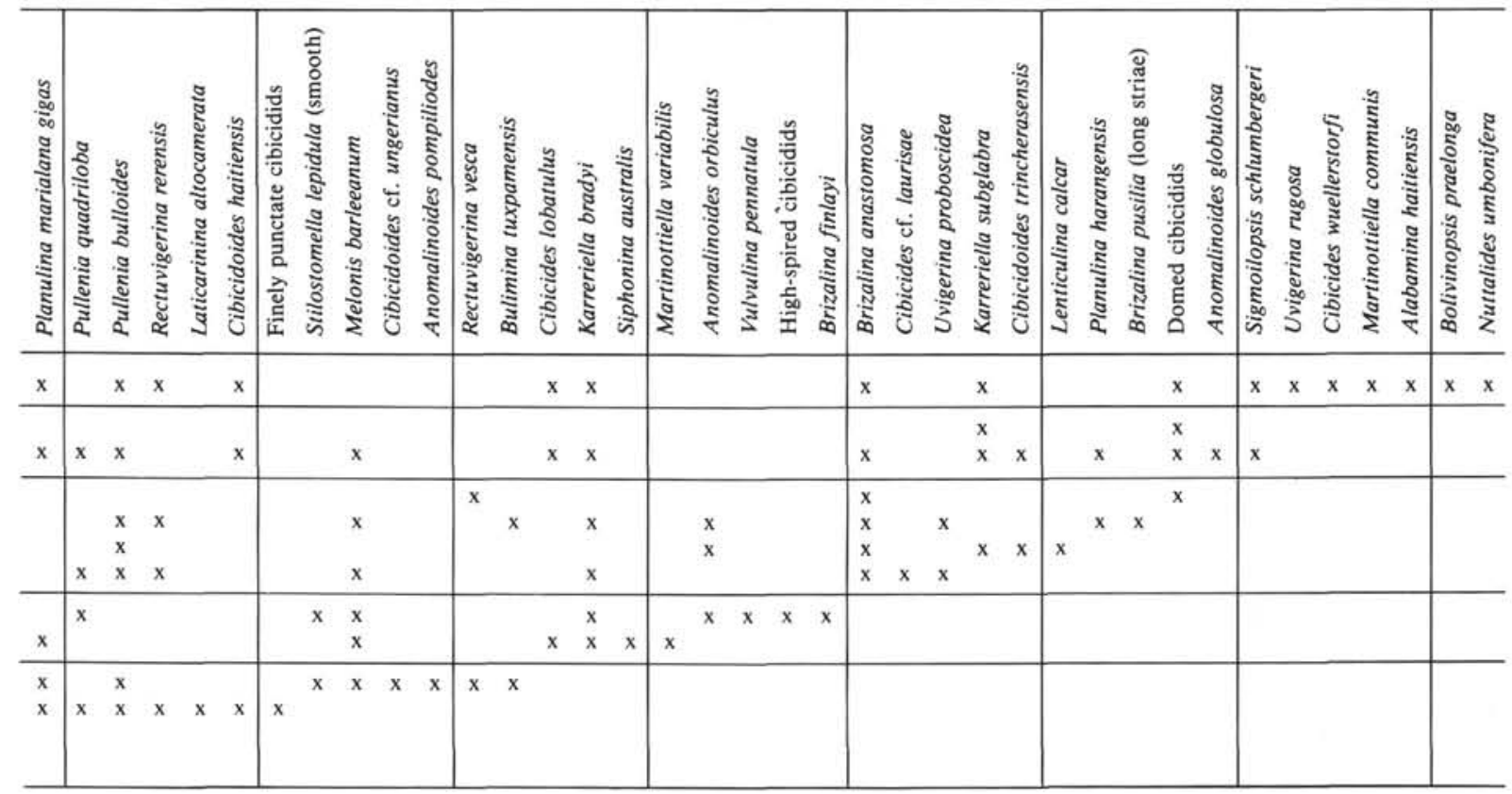


Table 18. Benthic foraminifers, Hole 593, late Miocene.

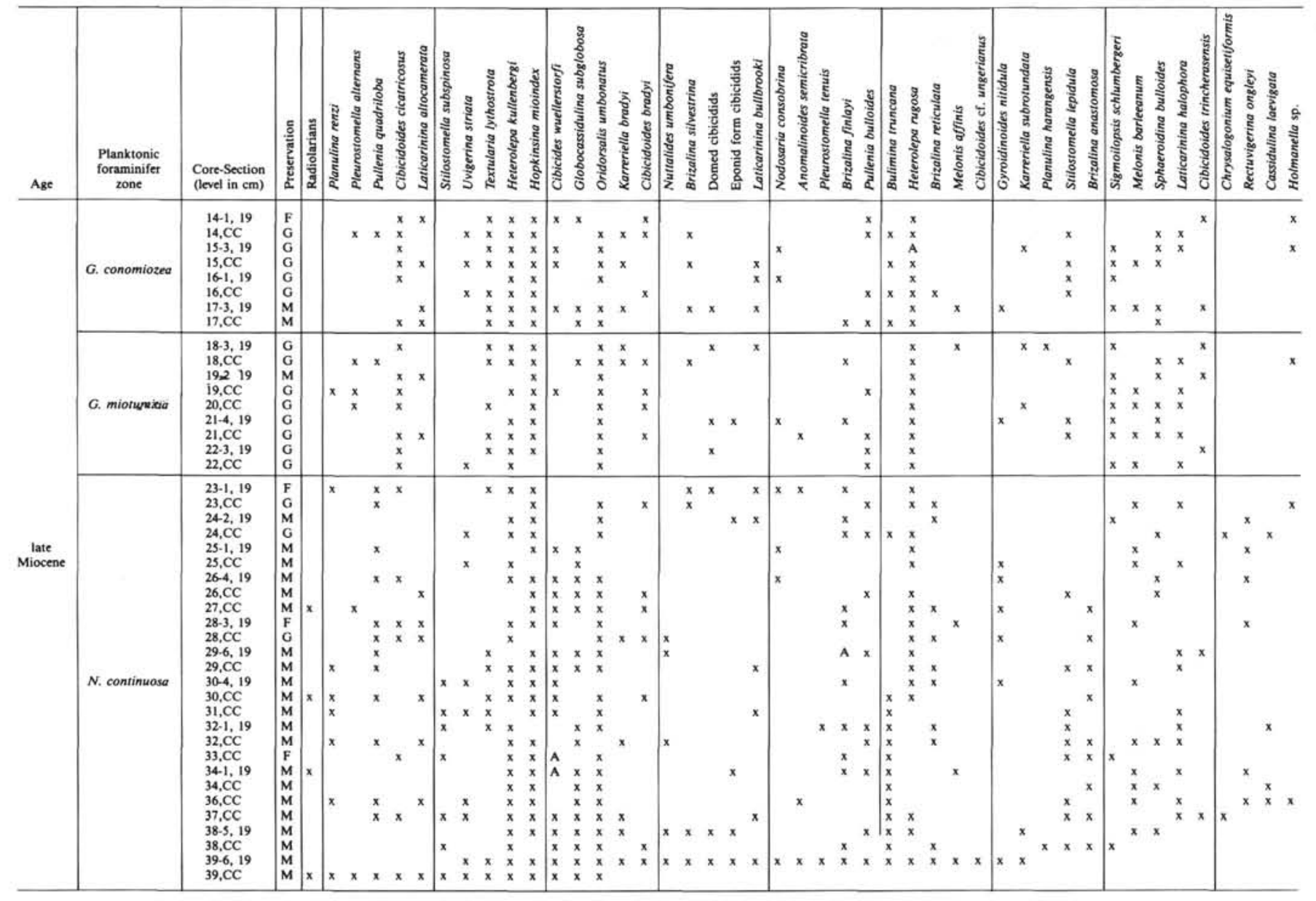

Table 19. Benthic foraminifers, Hole 593, Pliocene.

\begin{tabular}{|c|c|c|c|c|c|c|c|c|c|c|c|c|c|c|c|c|c|c|c|c|c|c|c|c|c|c|c|c|c|c|c|}
\hline Age & $\begin{array}{l}\text { Planktonic } \\
\text { foraminifer } \\
\text { zone }\end{array}$ & $\begin{array}{l}\text { Core-Section } \\
\text { (level in } \mathrm{cm} \text { ) }\end{array}$ & 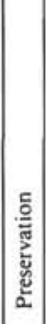 & 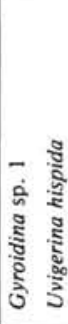 & 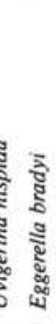 & 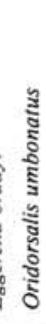 & 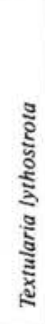 & 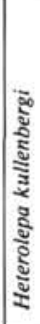 & 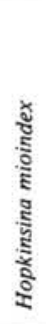 & 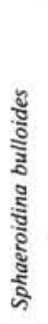 & 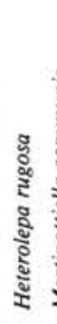 & 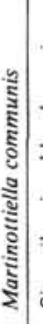 & 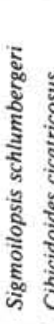 & 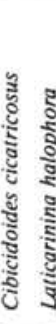 & 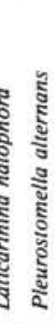 & 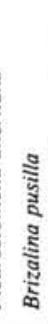 & 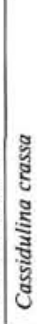 & 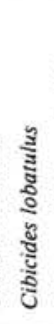 & 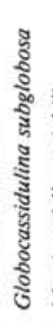 & 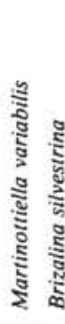 & & 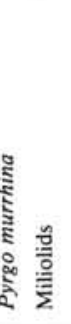 & 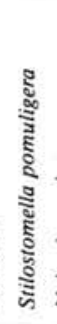 & 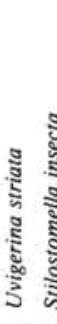 & & 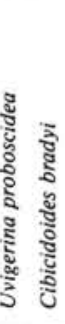 & 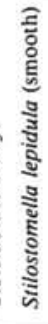 & 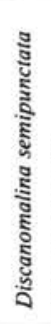 & 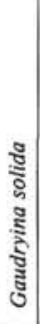 & 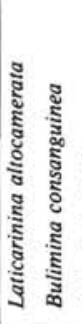 & 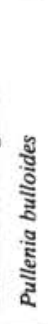 \\
\hline \multirow[b]{2}{*}{ Pliocene } & G. inflata & $\begin{array}{l}5-5,19 \\
5, C C \\
6-3,19\end{array}$ & $\begin{array}{l}\mathrm{G} \\
\mathrm{G} \\
\mathrm{G}\end{array}$ & $x$ & & $\begin{array}{l}x \\
x \\
x\end{array}$ & $\begin{array}{l}x \\
x\end{array}$ & $\begin{array}{l}x \\
x\end{array}$ & & $\begin{array}{l}x \\
x\end{array}$ & $\begin{array}{l}\mathrm{x} \\
\mathrm{x} \\
\mathrm{x}\end{array}$ & $\mathrm{x}$ & $\begin{array}{l}x \\
x\end{array}$ & & & & & $x$ & & & & $\begin{array}{ll}A & \\
x \quad x\end{array}$ & & $x$ & & & $\begin{array}{l}x \\
x\end{array}$ & & $\mathrm{x}$ & $x$ & $\begin{array}{l}x \\
A\end{array}$ \\
\hline & G. puncticulata & $\begin{array}{l}6, \mathrm{CC} \\
7, \mathrm{CC} \\
8, \mathrm{CC} \\
9-6,19 \\
9, \mathrm{CC} \\
11-4,19 \\
11, \mathrm{CC} \\
12-6,19 \\
12, \mathrm{CC} \\
13, \mathrm{CC}\end{array}$ & \begin{tabular}{|l|}
$G$ \\
$G$ \\
$G$ \\
$G$ \\
$G$ \\
$M$ \\
$G$ \\
$G$ \\
$G$ \\
$G$
\end{tabular} & $\begin{array}{ll} & x \\
x & \\
x & A \\
& x \\
x & x\end{array}$ & $\begin{array}{l}x \\
x \\
x\end{array}$ & $\begin{array}{l}\mathrm{x} \\
\mathrm{x} \\
\mathrm{x} \\
\mathrm{x} \\
\mathrm{x} \\
\mathrm{x} \\
\mathrm{x} \\
\mathrm{x} \\
\mathrm{x}\end{array}$ & $\begin{array}{l}\mathrm{x} \\
\mathrm{x} \\
\mathrm{x} \\
\mathrm{x}\end{array}$ & $\begin{array}{l}\mathrm{x} \\
\mathrm{x} \\
\mathrm{x} \\
\mathrm{x} \\
\mathrm{x} \\
\mathrm{x} \\
\mathrm{x} \\
\mathrm{x} \\
\mathrm{x} \\
\mathrm{x}\end{array}$ & $\begin{array}{l}\mathrm{x} \\
\mathrm{x} \\
\mathrm{x} \\
\mathrm{x} \\
\mathrm{x} \\
\mathrm{x} \\
\mathrm{x}\end{array}$ & $\begin{array}{l}x \\
x \\
x \\
x \\
x \\
x \\
x \\
x\end{array}$ & $\begin{array}{l}\mathrm{x} \\
\mathrm{x} \\
\mathrm{x} \\
\mathrm{x} \\
\mathrm{x} \\
\mathrm{x} \\
\mathrm{x}\end{array}$ & $\begin{array}{l}x \\
x \\
x \\
x \\
x \\
x\end{array}$ & $\begin{array}{l}x \\
x \\
\\
x \\
x \\
x \\
x \\
x\end{array}$ & $\begin{array}{ll} & \\
x & \\
x & x \\
x & \\
& x \\
x & x \\
x & x \\
x & x \\
x & x\end{array}$ & $\begin{array}{ll}x & \\
x & \\
x & \\
x & x \\
x & \\
x & x\end{array}$ & $\begin{array}{l}x \\
x \\
\\
x \\
x \\
x \\
x \\
x \\
x \\
x\end{array}$ & $\begin{array}{l}x \\
x \\
x \\
x \\
x\end{array}$ & $\begin{array}{l}x \\
x\end{array}$ & $\begin{array}{l}\mathrm{x} \\
\mathrm{x} \\
\mathrm{x} \\
\mathrm{x} \\
\mathrm{x} \\
\mathrm{x} \\
\mathrm{x}\end{array}$ & $x^{x}$ & & $\begin{array}{cc}\mathrm{x} & \mathrm{A} \\
\mathrm{x} & \mathrm{x} \\
& \mathrm{x} \\
& \mathrm{x} \\
\mathrm{x} & \mathrm{x} \\
\mathrm{x} & \mathrm{x} \\
& \mathrm{x} \\
\mathrm{x} & \mathrm{x} \\
\mathrm{x} & \mathrm{x}\end{array}$ & $\begin{array}{l}\mathrm{x} \\
\\
\\
\mathrm{x} \\
\mathrm{x}\end{array}$ & $\begin{array}{lll} & \\
& \\
x & x \\
x & x\end{array}$ & $\begin{array}{l}\mathrm{x} \\
\mathrm{x} \\
\mathrm{x}\end{array}$ & $\begin{array}{ll}x & \\
x & \\
& x\end{array}$ & $\begin{array}{l}x \\
x\end{array}$ & $\begin{array}{l}\mathrm{x} \\
\mathrm{x} \\
\mathrm{x} \\
\mathrm{x} \\
\mathrm{x} \\
\mathrm{x} \\
\mathrm{x}\end{array}$ & $\mathrm{x}$ & \multicolumn{2}{|c|}{$\begin{array}{lll}x & x & x\end{array}$} \\
\hline
\end{tabular}


Table 18. (Continued).

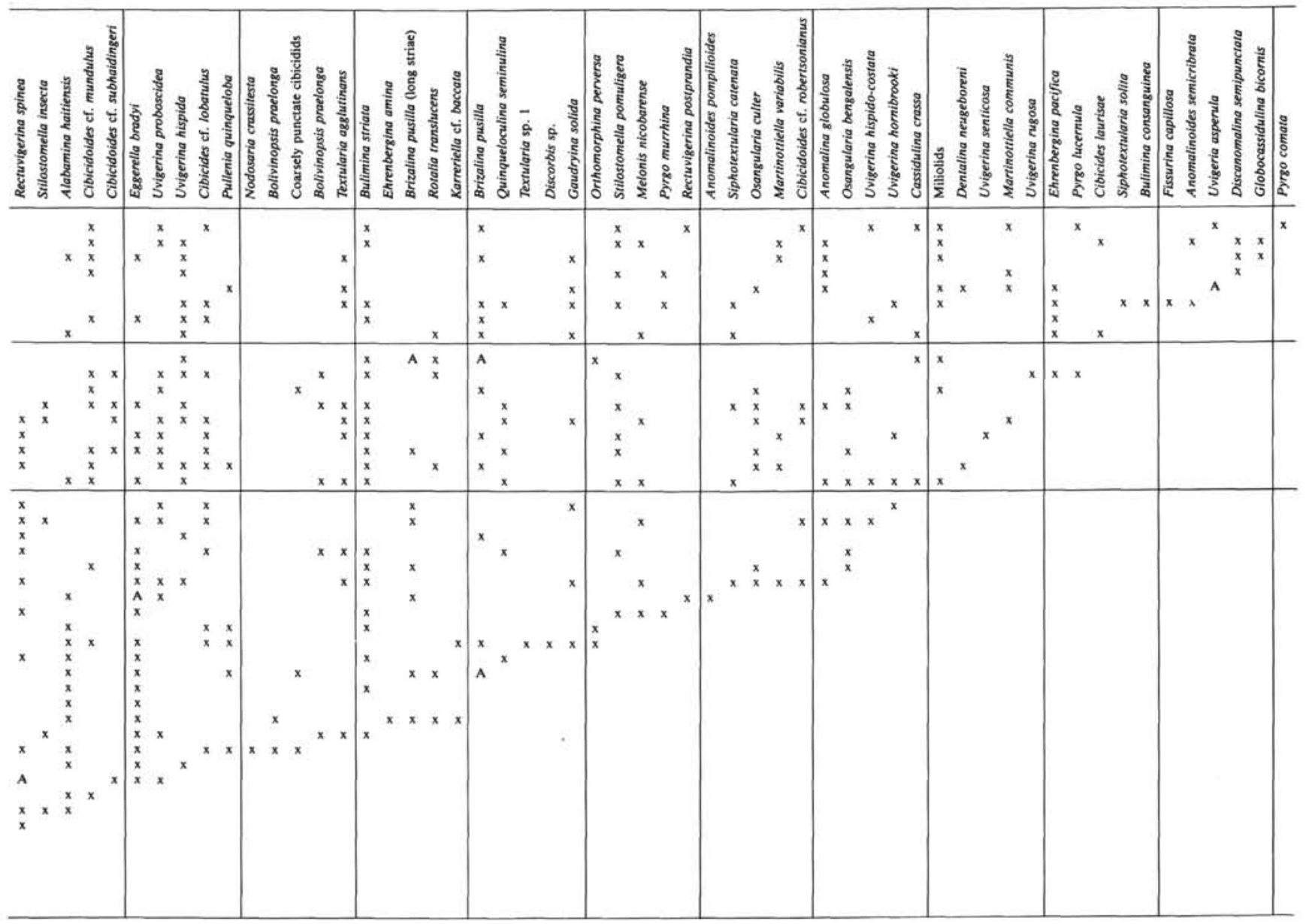

Table 19. (Continued).

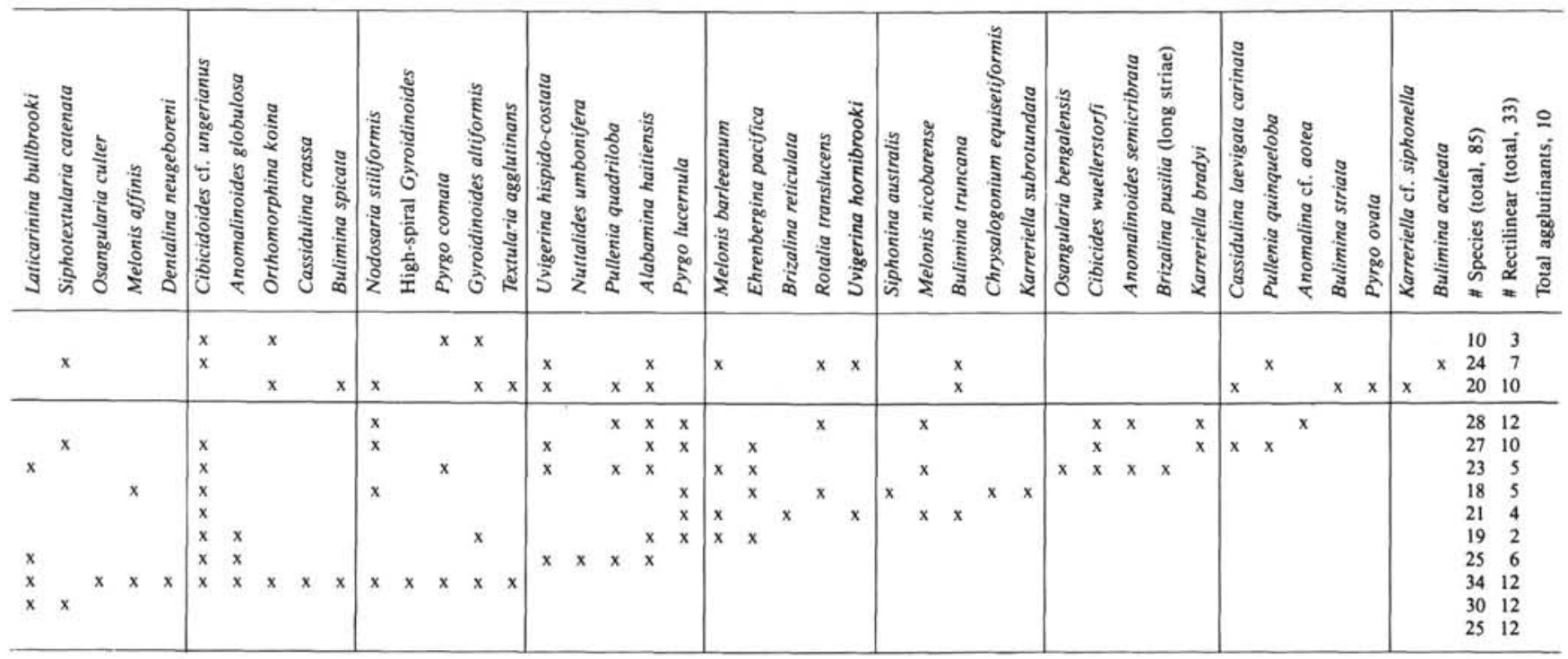


Table 20. Benthic foraminifers, Hole 594, early Miocene.

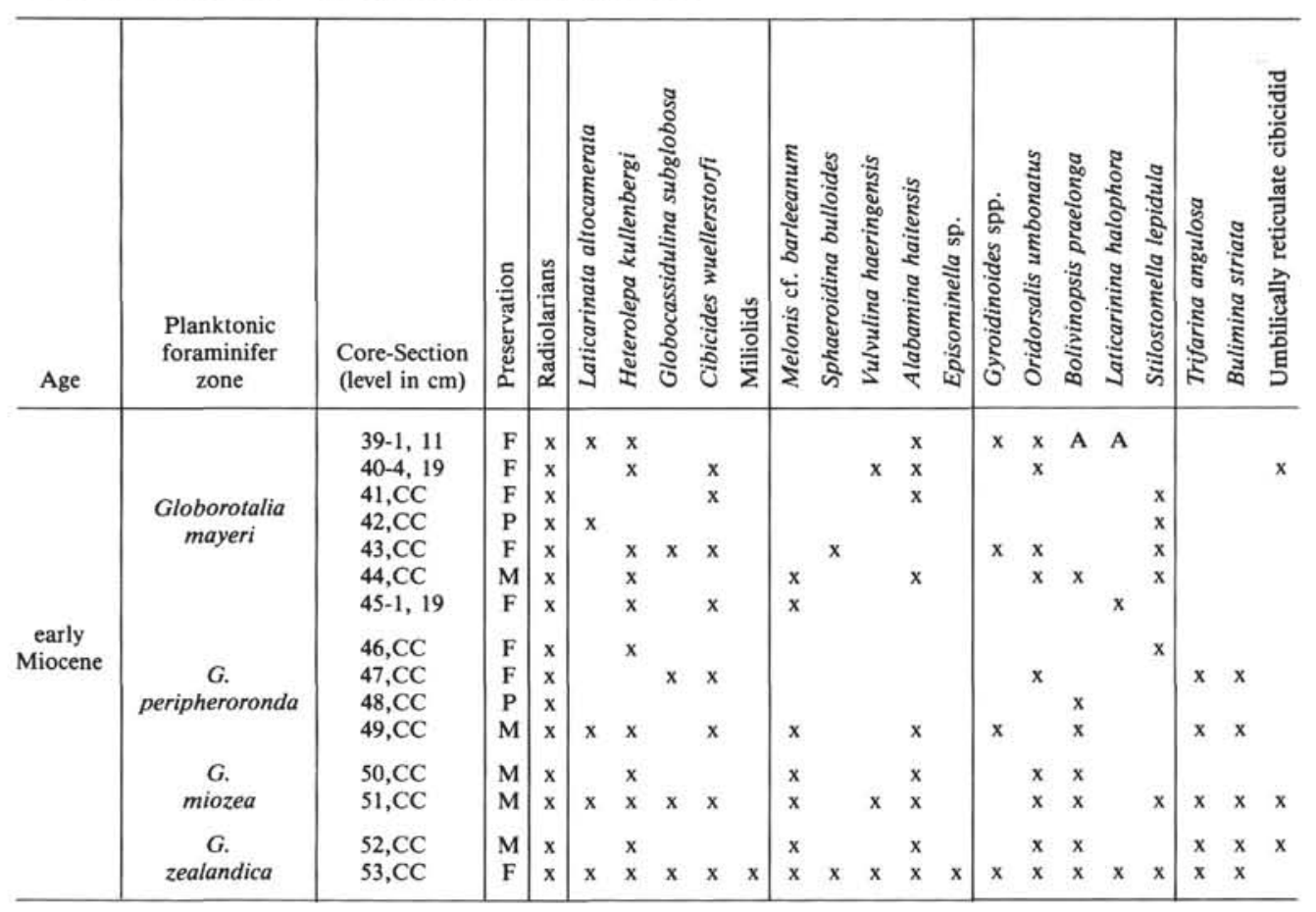

Table 21. Benthic foraminifers, Hole 594, middle Miocene.

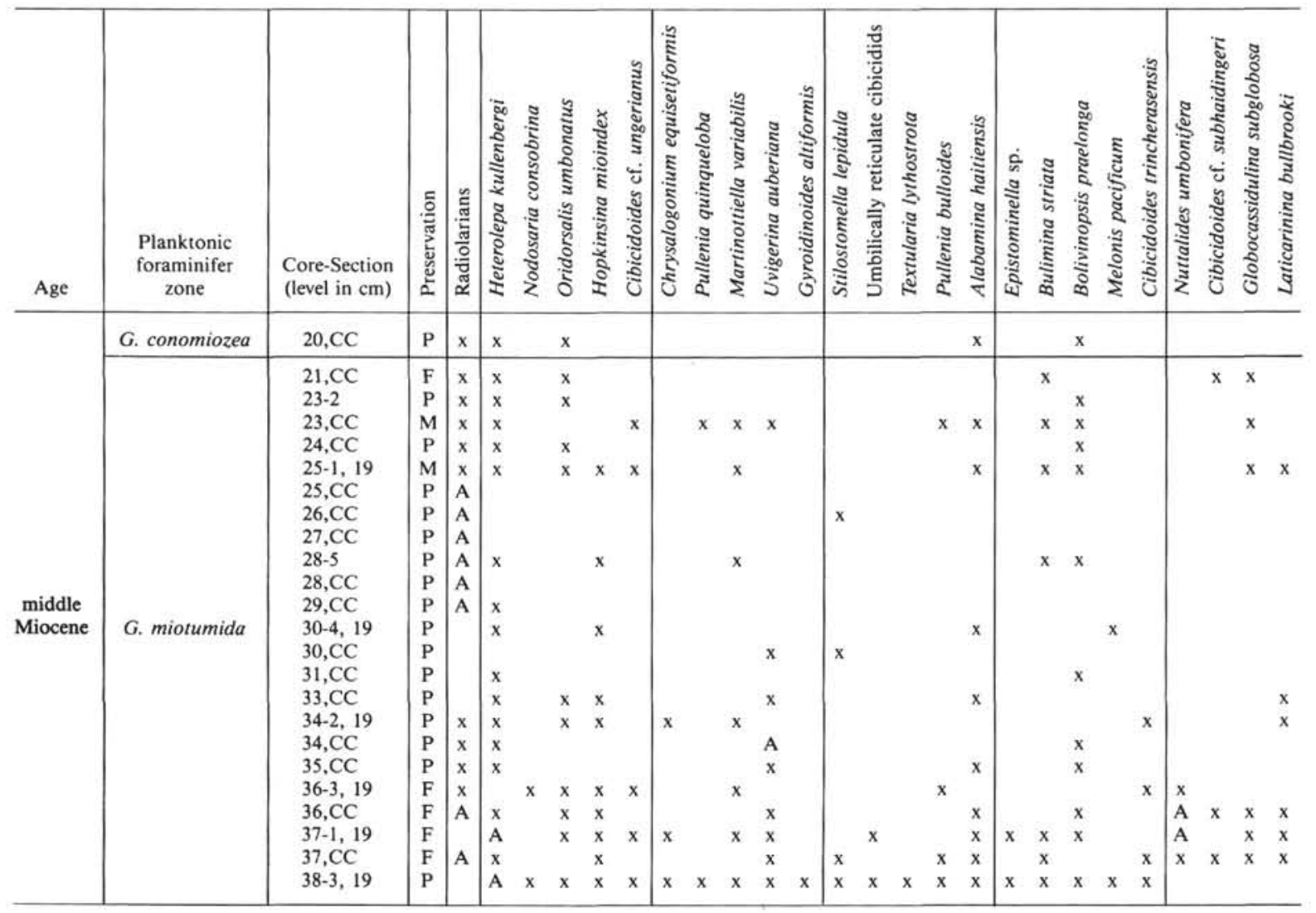


Table 20. (Continued).

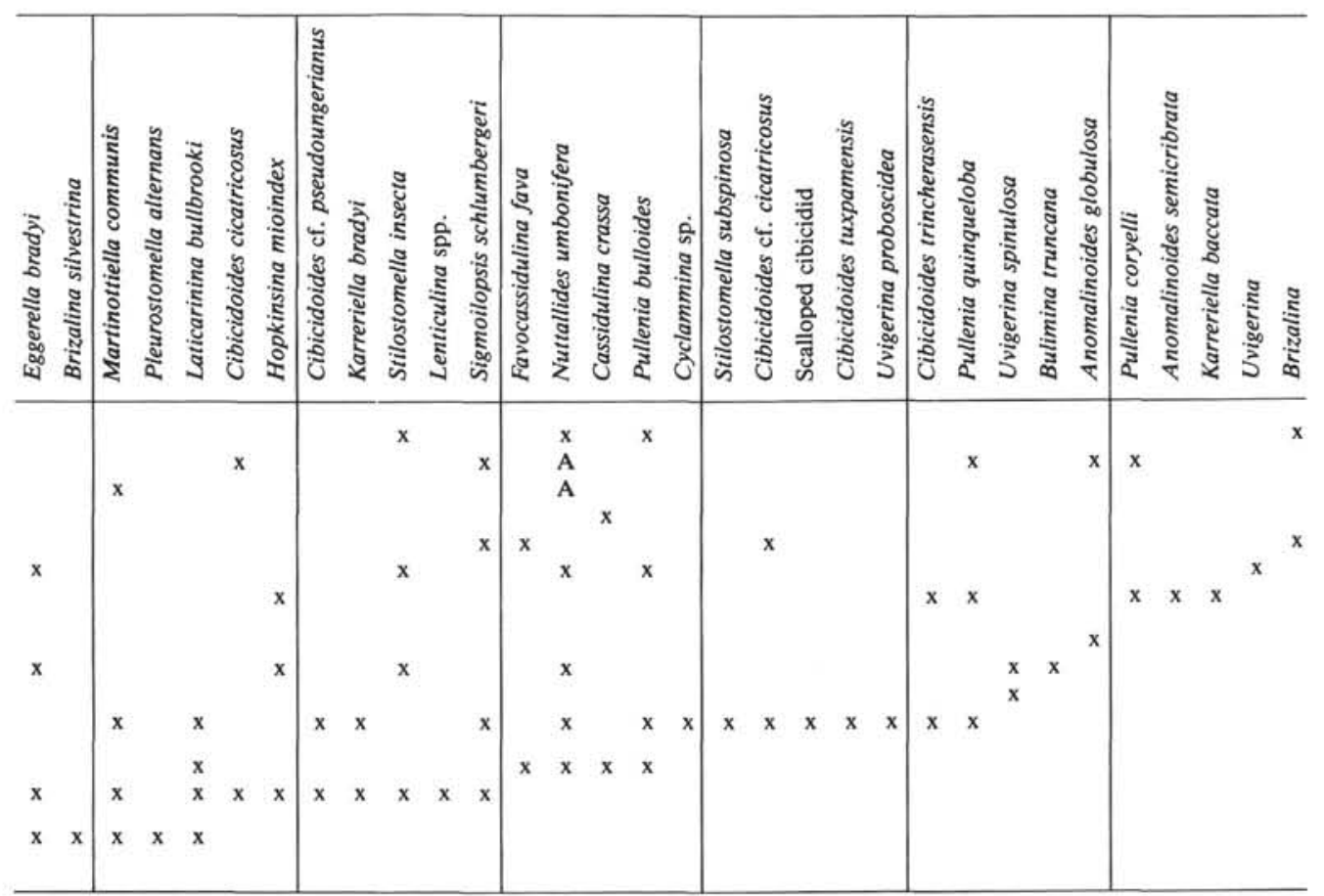

Table 21. (Continued).

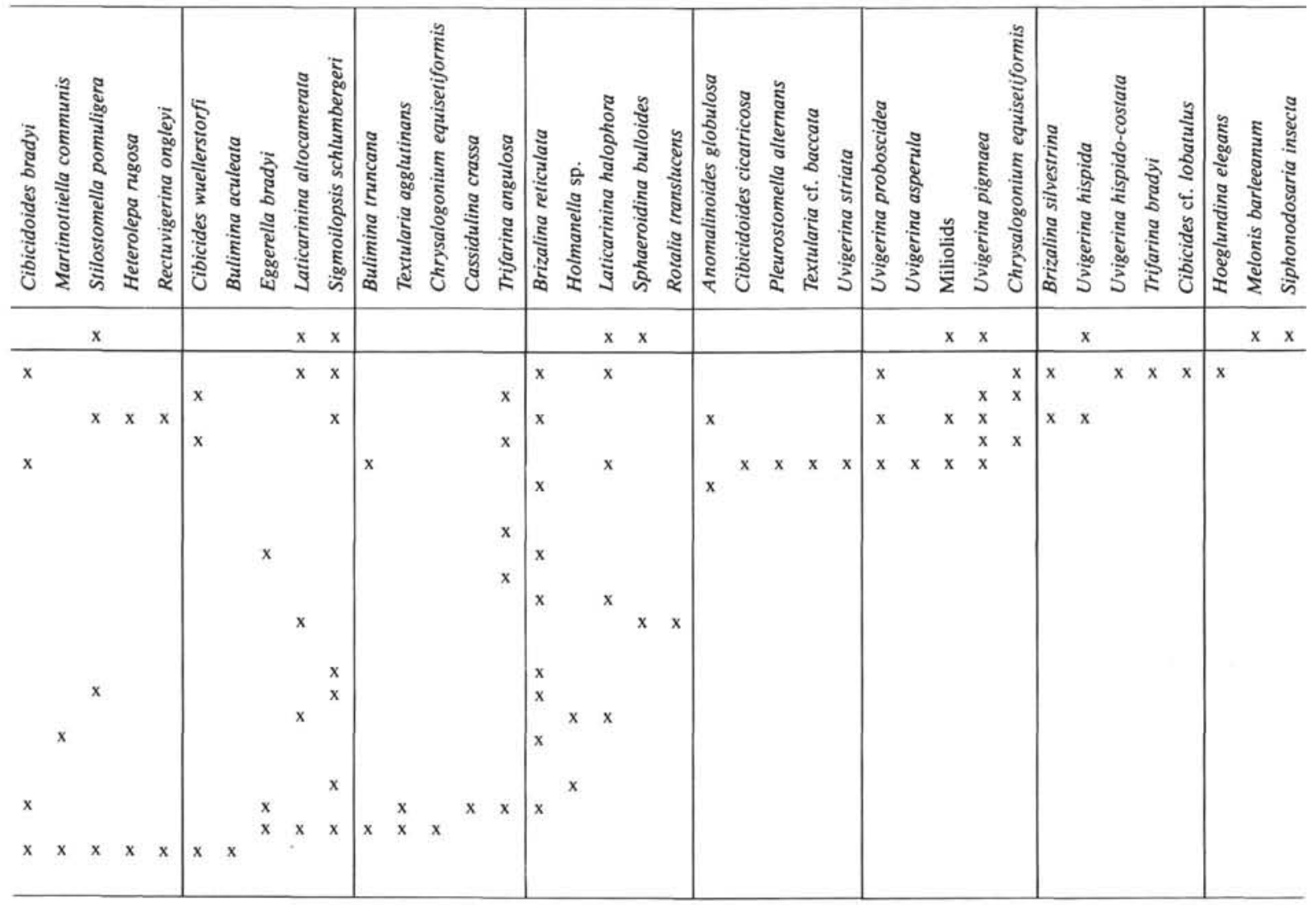


Table 22. Benthic foraminifers. Hole 594, Pliccene.

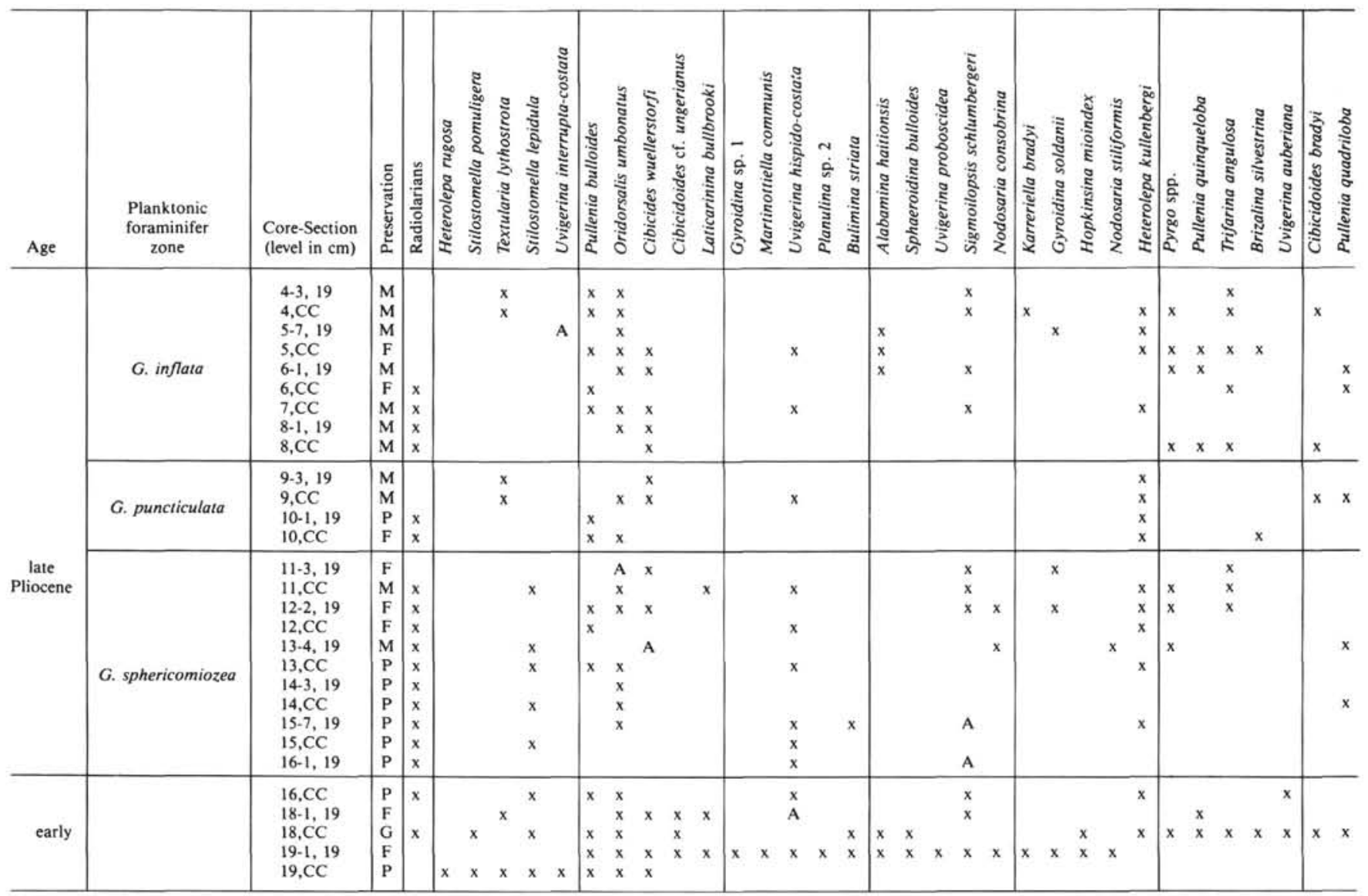


Table 22. (Continued).

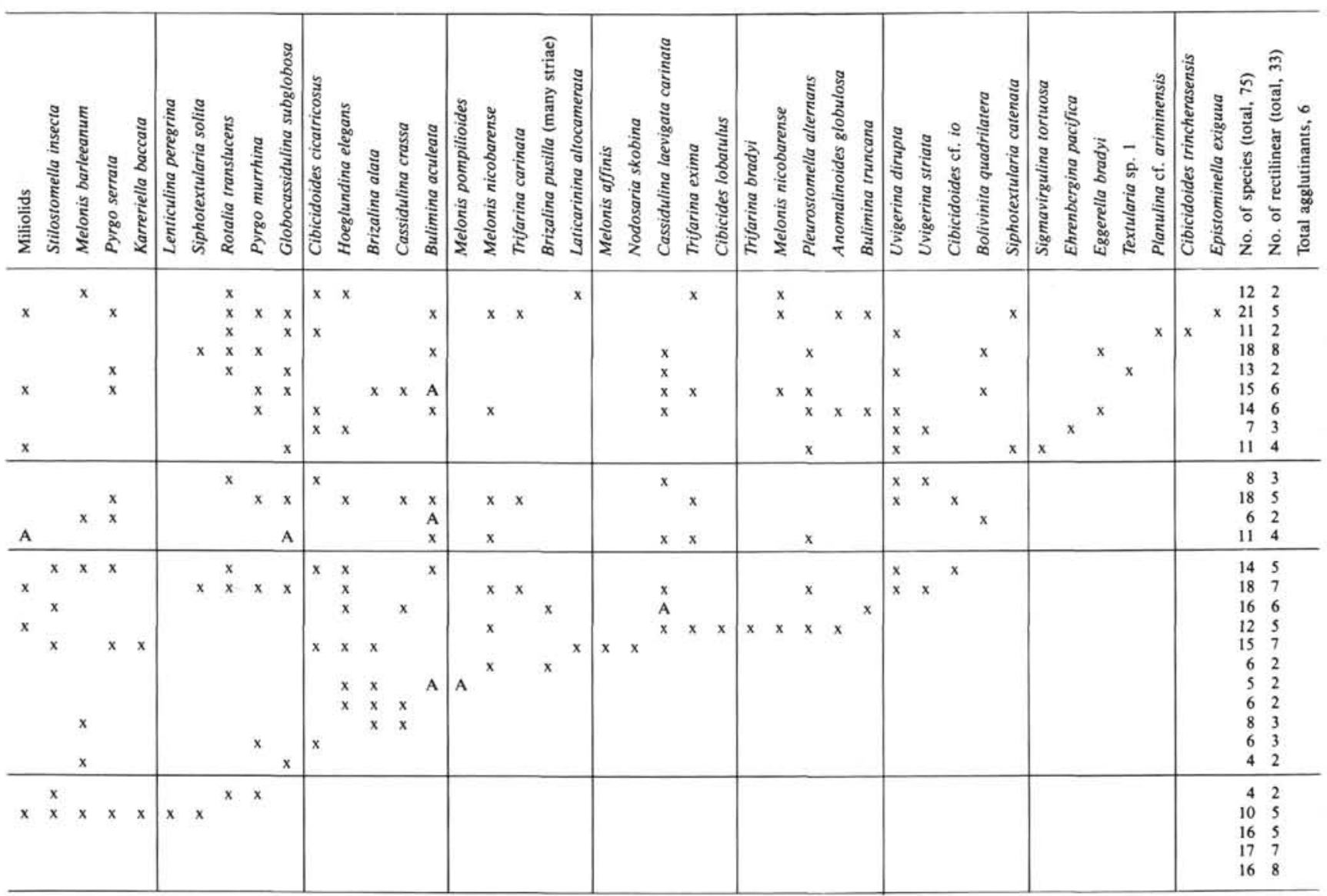




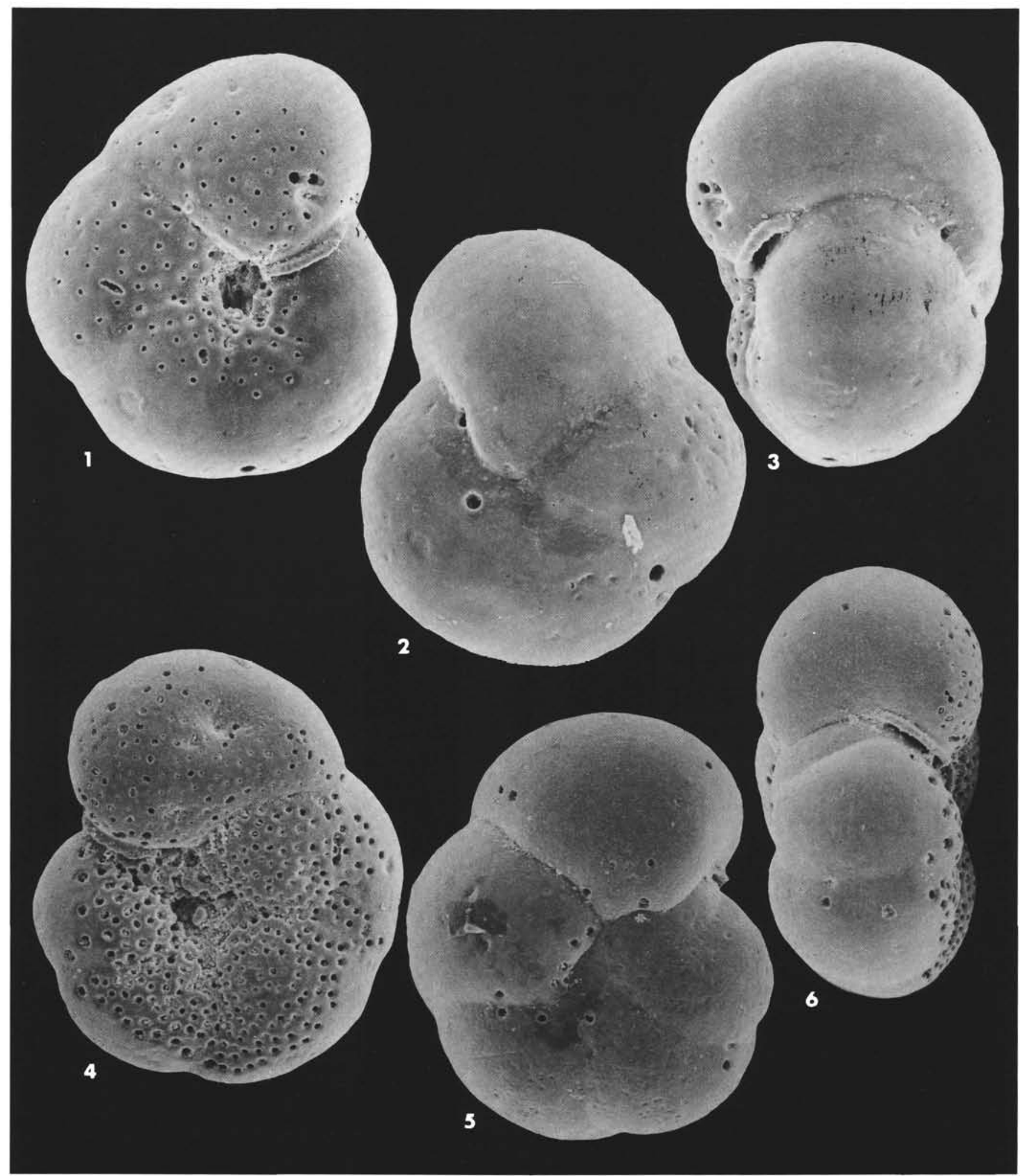

Plate 1. 1-6. Anomalinoides semicribrata (Beckman), (1-3) Sample 590A-5,CC $(1, \times 330 ; 2, \times 290 ; 3, \times 330)$; (4-6) Sample 588-16-3, 40 cm (4, 5, $\times 160 ; 6, \times 150$ ). 


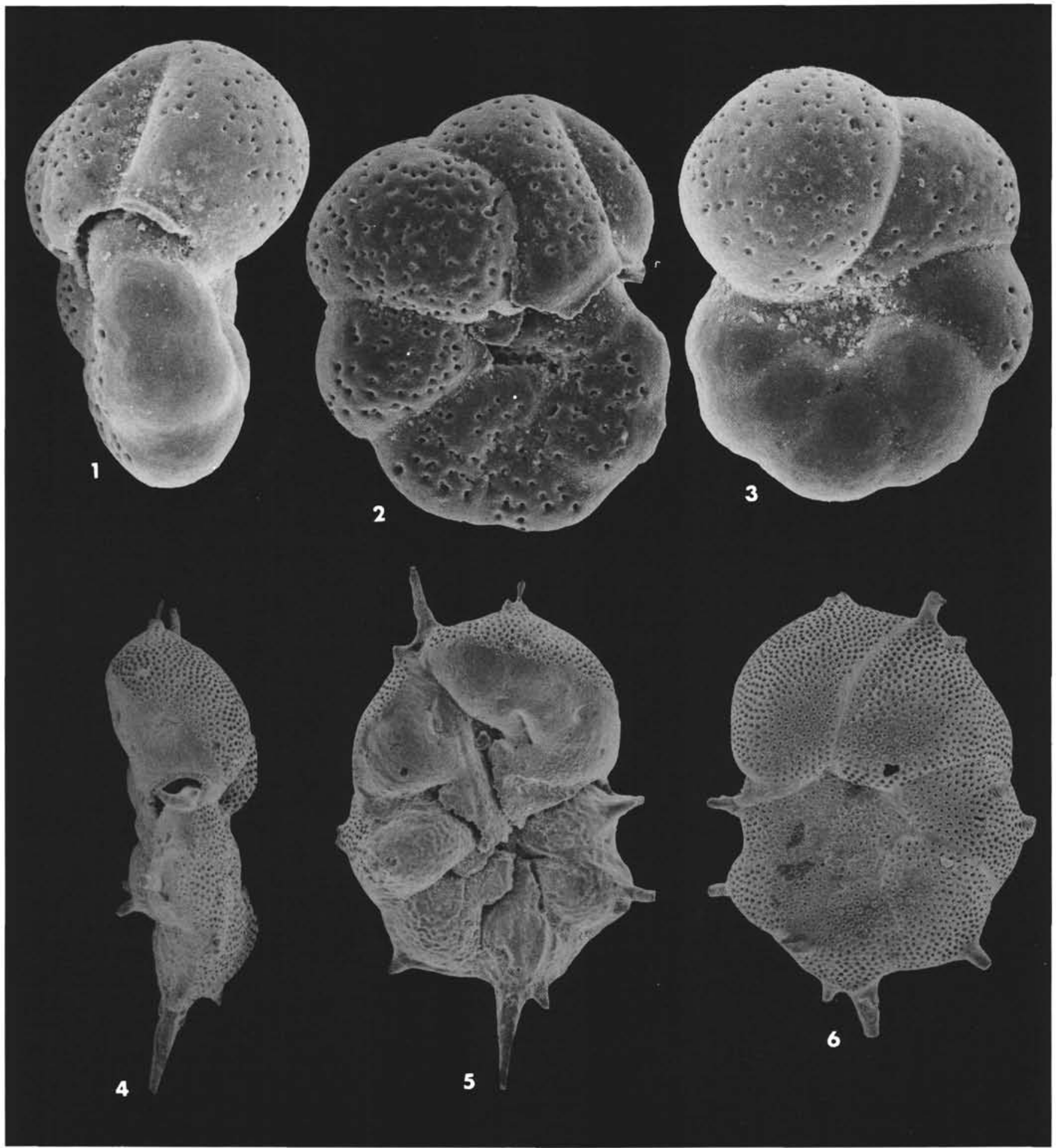

Plate 2. 1-3. Anomalinoides globulosa (Chapman and Parr), Sample 593-21,CC, $\times 270$. 4-6. Discanomalina semipunctata (Bailey), (4) $\times 60$, (5) $\times 63,(6) \times 58$. 


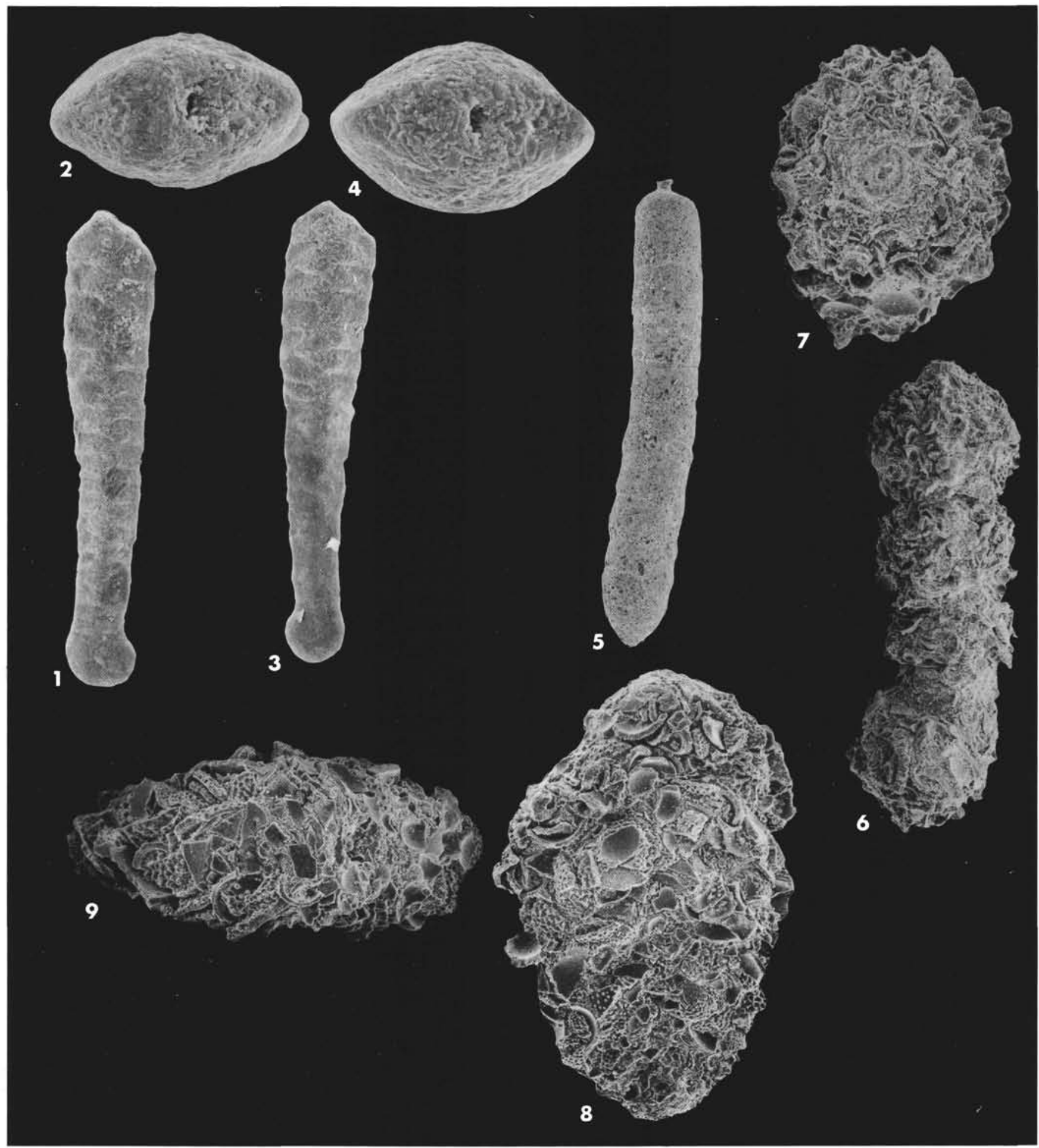

Plate 3. 1-2. Bolivinopsis cubensis, Sample 592-23-2, $19 \mathrm{~cm},(1) \times 146,(2) \times 400$. 3-4. Bolivinopsis praelonga (Schwager), Sample 594-30,CC, (3) $\times 101,(4) \times 250$. 5. Martinottiella communis (d'Orbigny), Sample 590A-6, CC, $\times 39$. 6-7. Martinottiella variabilis (Schwager), Sample $591-16$, CC, $(6) \times 69,(7) \times 115$. 8-9. Textularia lythostrota, Sample 593-1,C, $(8) \times 100,(9) \times 120$. 


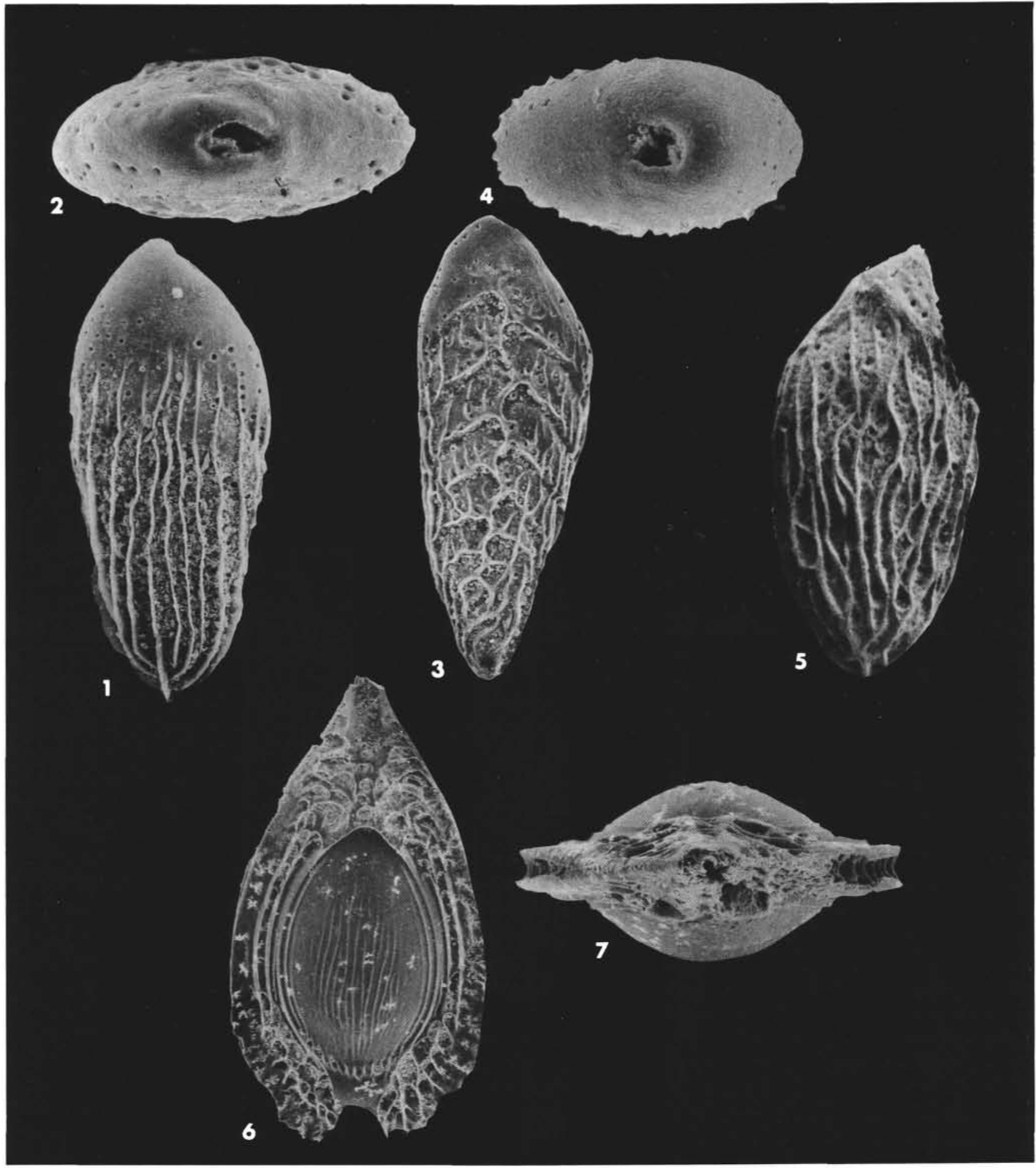

Plate 4. 1-2. Brizalina pusilla (Schwager), Sample 591-12,CC, (1) $\times 280,(2) \times 470$. 3-4. Brizalina finlayi (Hornibrook), Sample 593-27,CC, (3) $\times 220$, (4) $\times 470$. 5. Brizalina reticulata (Hantken), Sample 525B-19,CC, $\times 220$. 6-7. Fissurina capillosa Schwager, Sample 591-4,CC, (6) $\times 101,(7) \times 160$. 


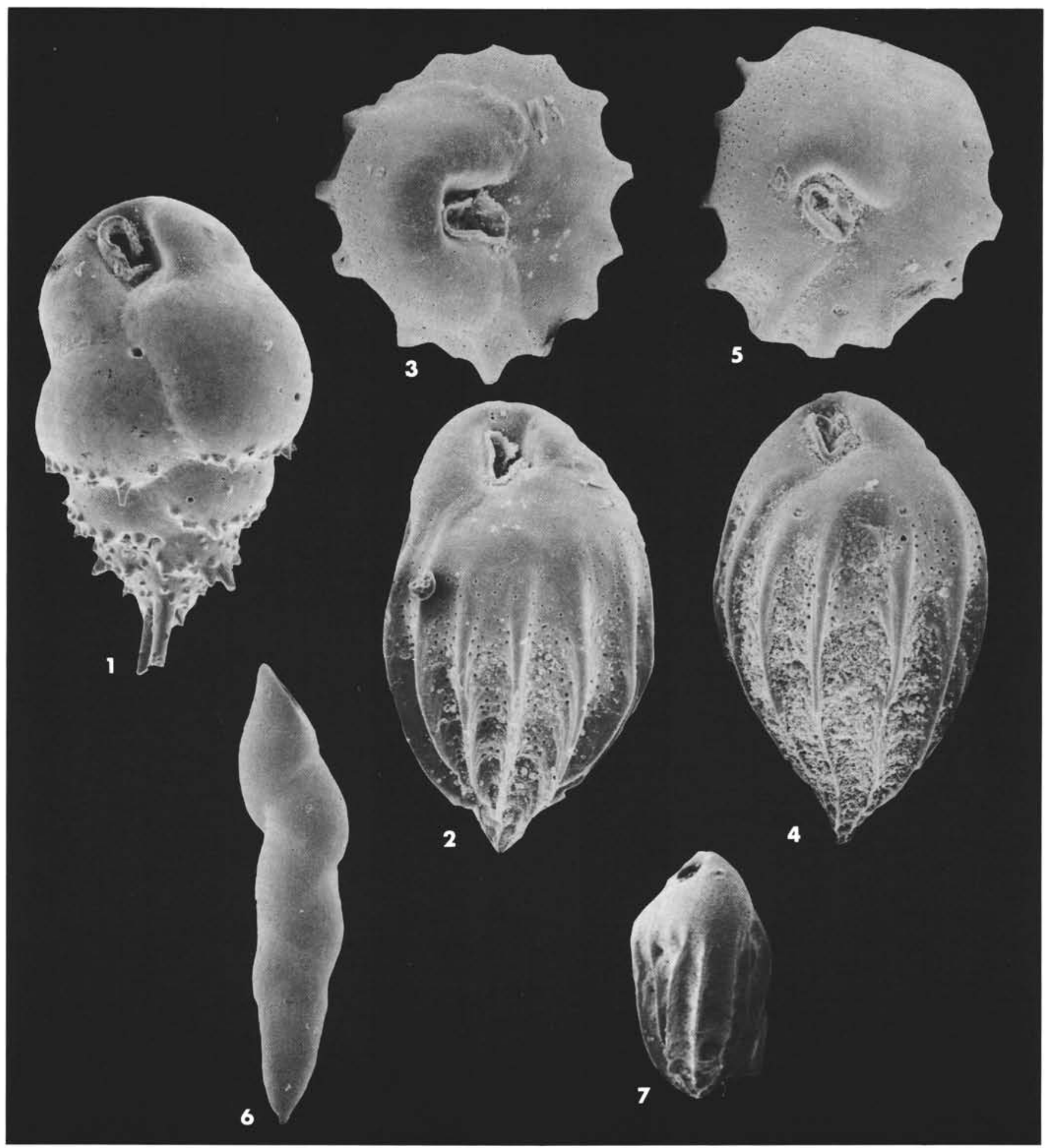

Plate 5. 1. Bulimina aculeata d'Orbigny, Sample $590 \mathrm{~A}-16, \mathrm{CC}, \times 120$. 2-5. Bulimina truncana Guembel, $(2-3)$ Sample $591-16, \mathrm{CC}(2, \times 230 ; 3$, $\times 196) ;(4-5)$ Sample 591-12,CC $(4, \times 200 ; 5, \times 230)$. 6. Pleurostomella alternans Schwager, Sample 590-3,CC, $\times 66$. 7. Bulimina alazanensis Nuttall, Sample 526A-41-2, $44 \mathrm{~cm}, \times 110$. 


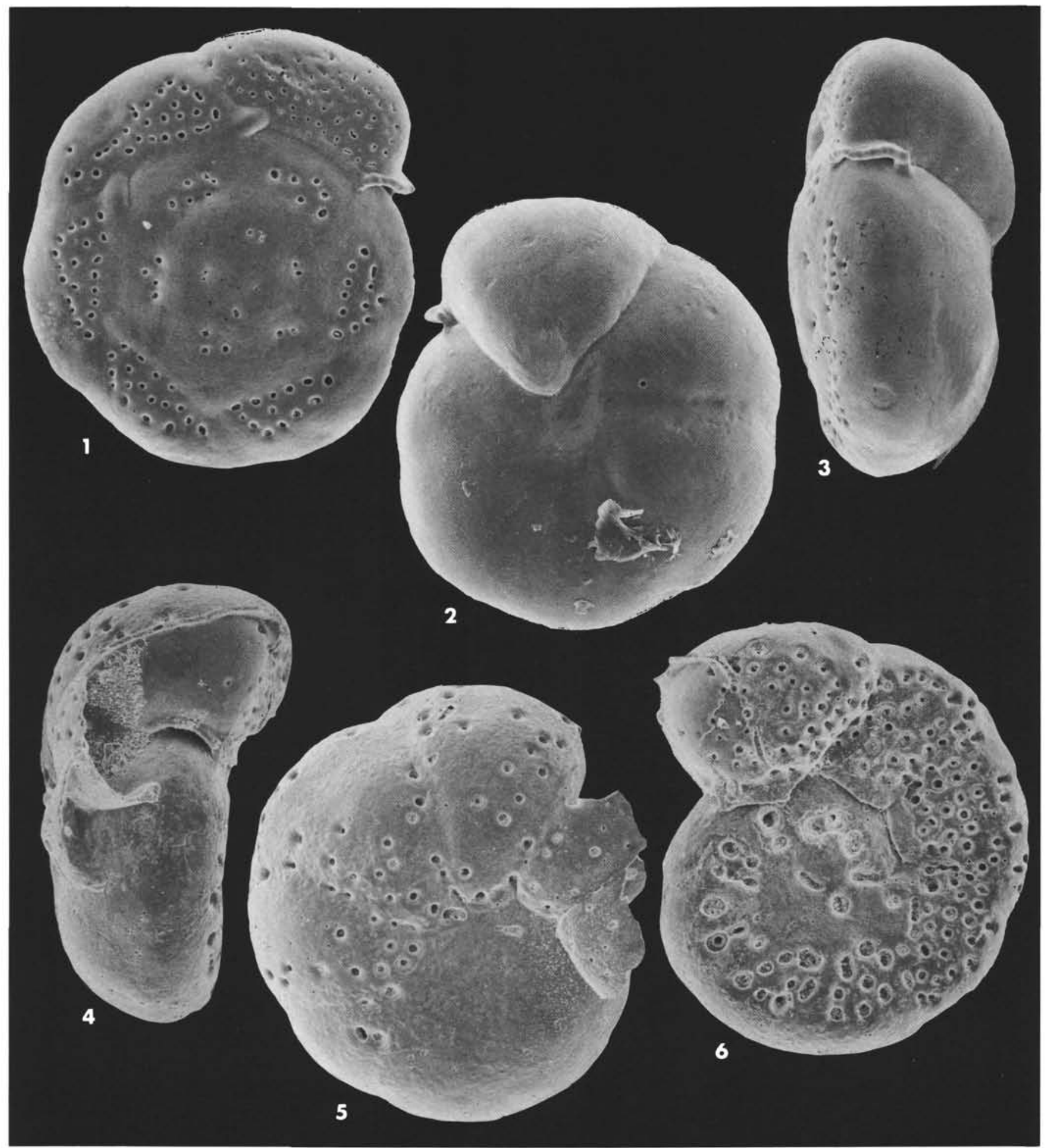

Plate 6. 1-3. Cibicidoides bradyi (Trauth), Sample 593-1,CC, $\times 195$. 4-6. Cibicidoides cicatricosus (Schwager), Sample 589-1,CC, (4, $\times 142$; 5 , $6, \times 145)$. 


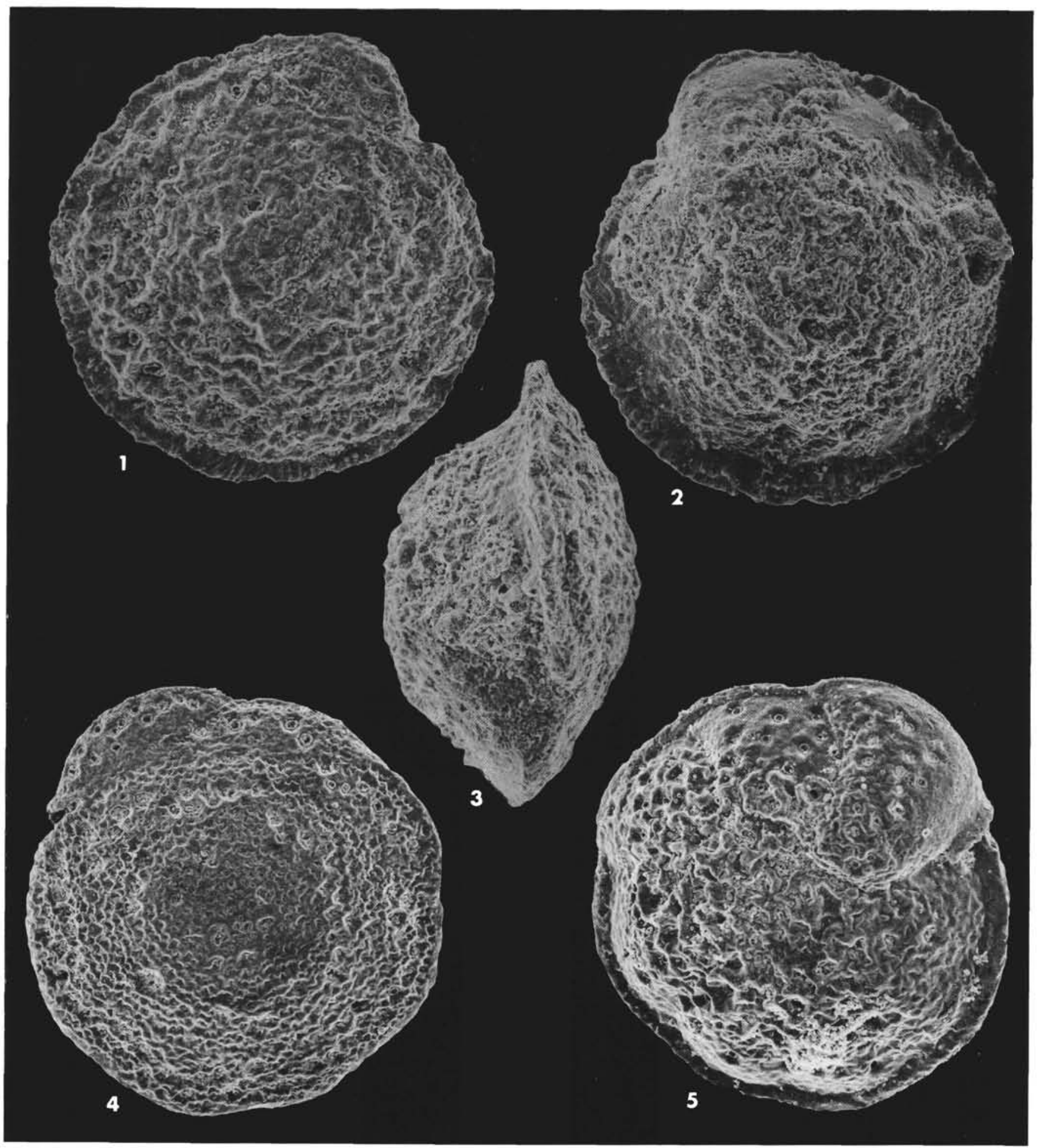

Plate 7. 1-5. Cibicidoides parki (Finlay), (1-3) Sample 548A-18-1, $65 \mathrm{~cm}, \times 180 ;(4-5)$ Sample 592-36-3, 92 cm (4, × 140; $5, \times 147)$. 


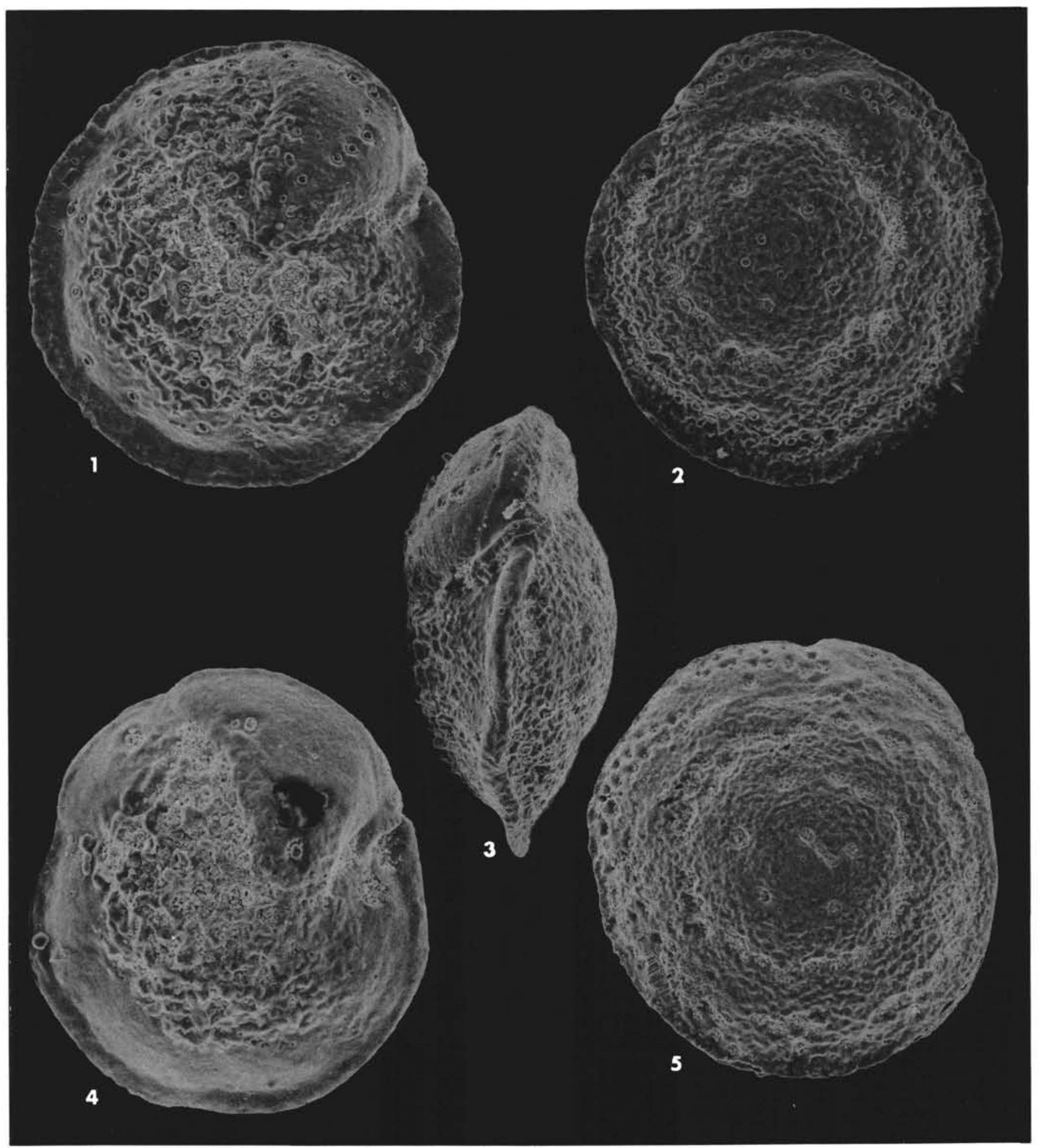

Plate 8. 1-5. Cibicidoides parki (Finlay) Sample 592-41,CC, (1) $\times 143 ;(2,5) \times 137 ;(3) \times 140 ;(4) \times 180$. 


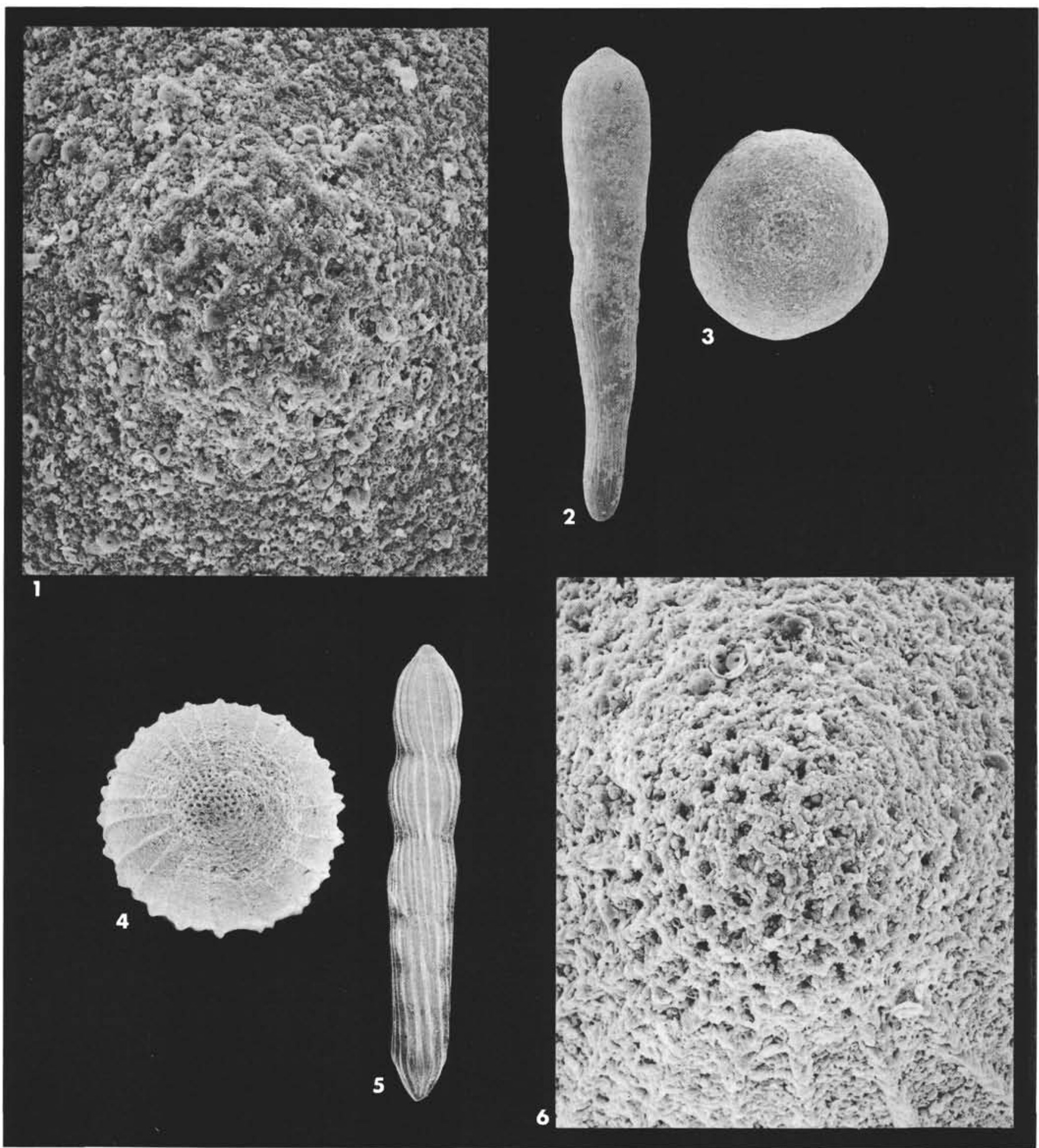

Plate 9. 1-3. Chrysalogonium equisetiformis Schwager, Sample 591-16,CC, $(1) \times 730$, detail of aperture enlarged; $(2,3) \times 125$. 4-6. Chrysalogonium spirostriolata Schwager, Sample 591-22,CC, (4) $\times 140$; (5) $\times 34 ;(6) \times 650$. 


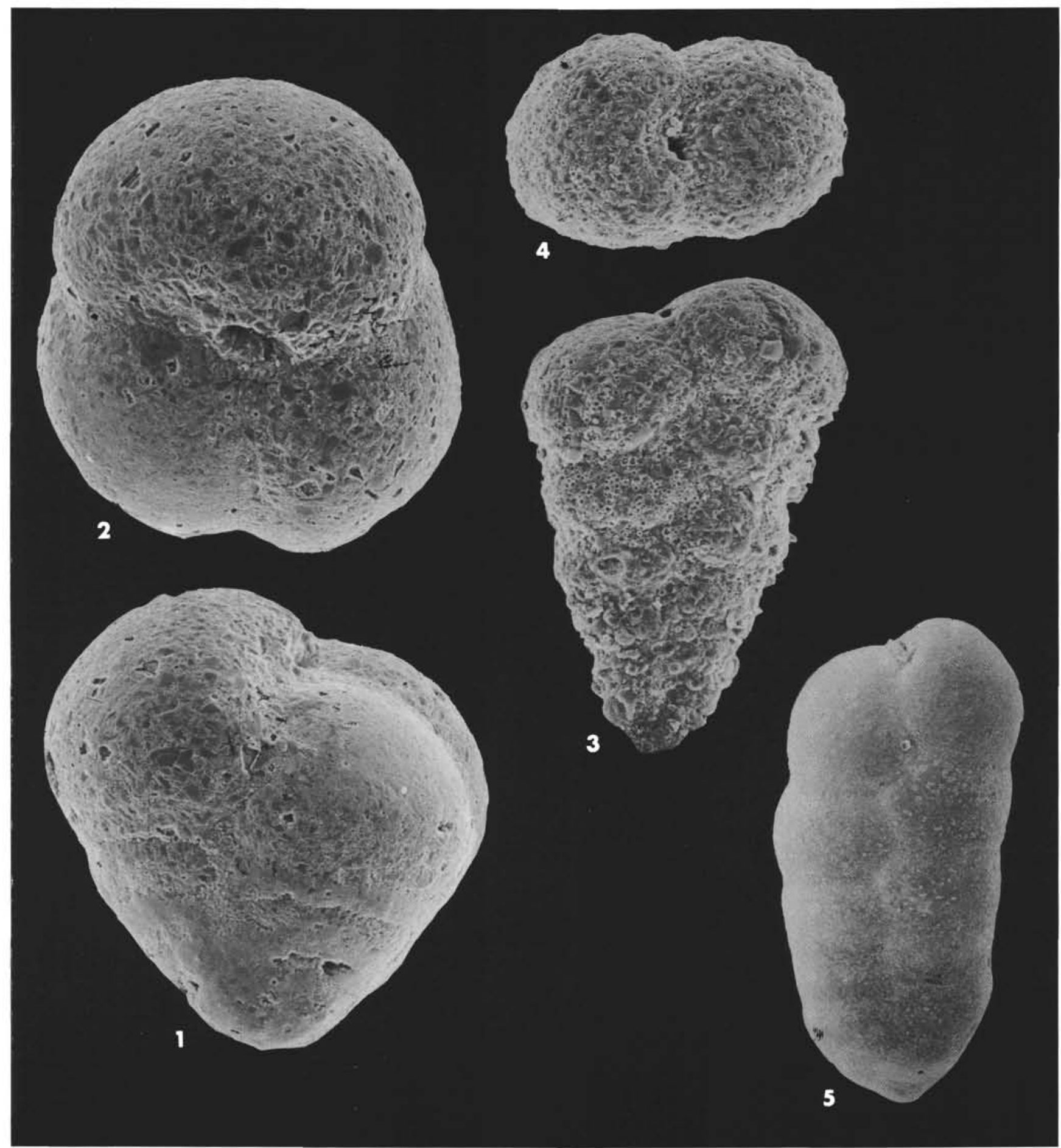

Plate 10. 1-2. Eggerella bradyi Cushman, Sample 593, 1,CC, (1) $\times 220$; (2) $\times 190$. 3-4. Textularia agglutinans d'Orbigny, Sample 591-12,CC, (3) $\times 275$; (4) $\times 300$. 5. Karreriella bradyi Cushman, Sample 591-7,CC, $\times 90$. 


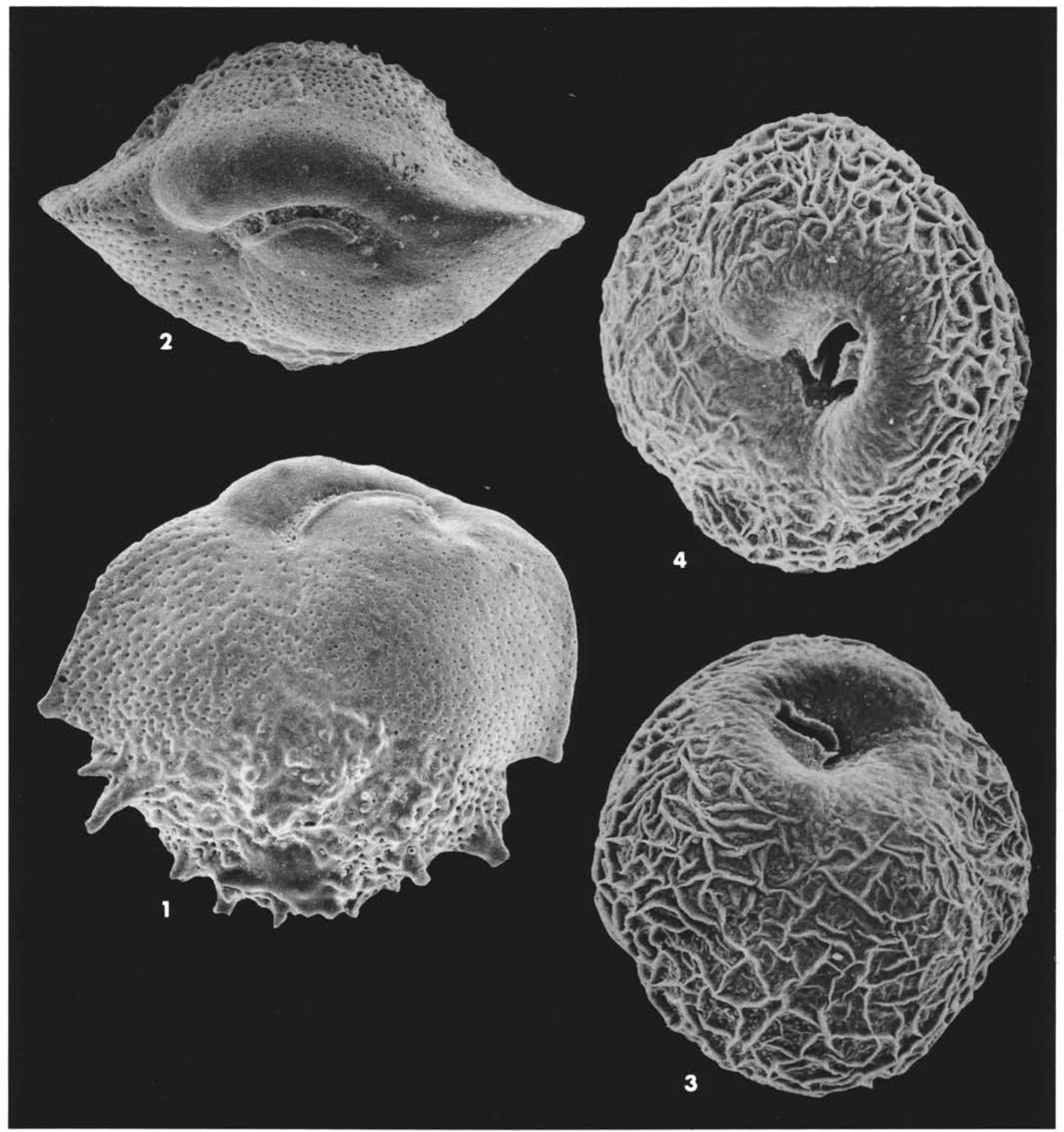

Plate 11. 1-2. Ehrenbergina marwicki Finlay, Sample 590-16,CC, (1) $\times 290$; (2) $\times 280$. 3-4. Globocassidulina arata (Finlay), Sample 590-3,CC, (3) $\times 250$; (4) $\times 200$. 


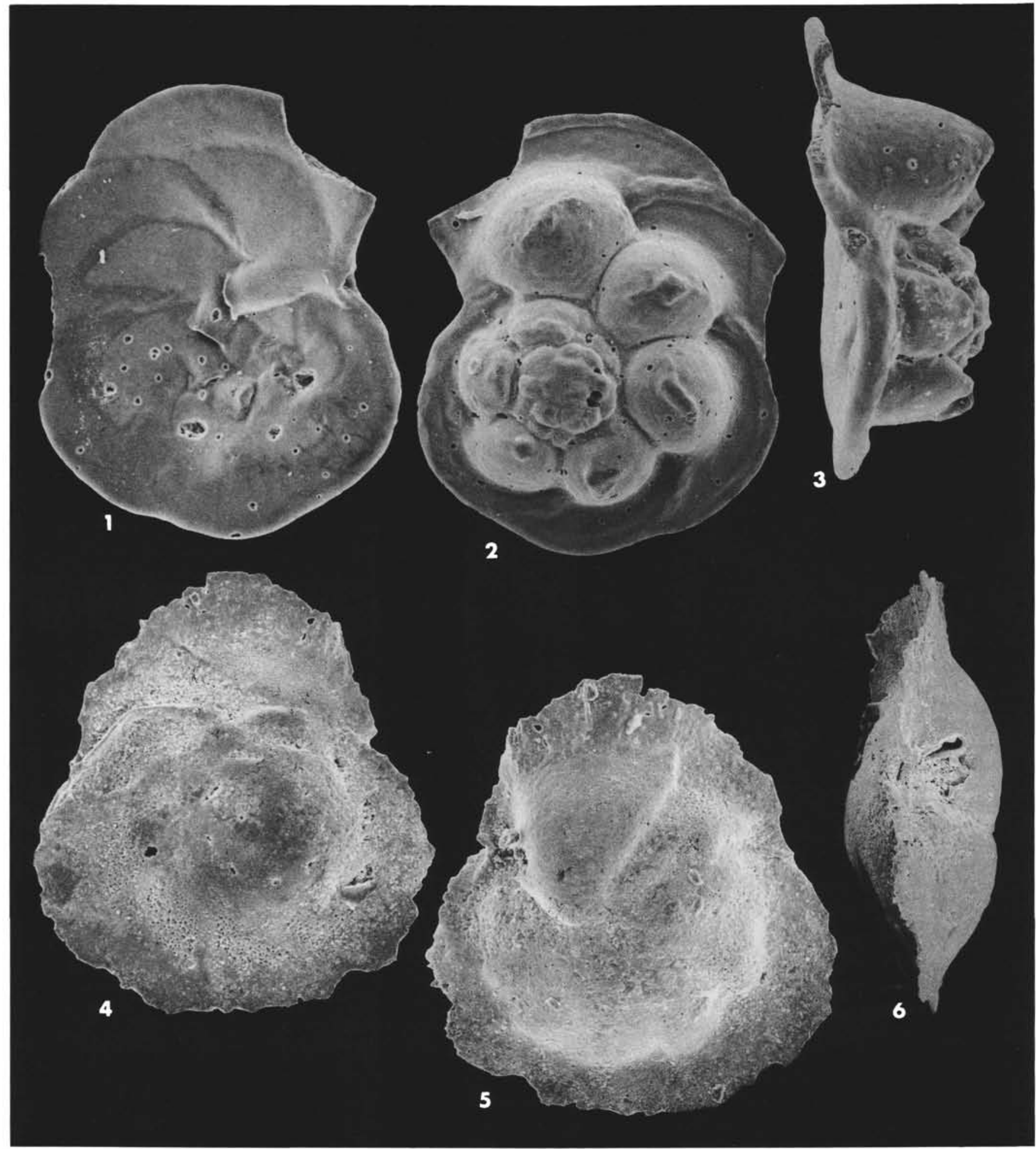

Plate 12. 1-3. Laticarinina altocamerata Chapman and Parr, Sample 590A-1,CC, (1) $\times 155 ;(2) \times 155 ;(3) \times 163$. 4-6. Osangularia culter (Parker and Jones), Sample 593-21,CC, $(1) \times 110 ;(2,3) \times 125$. 


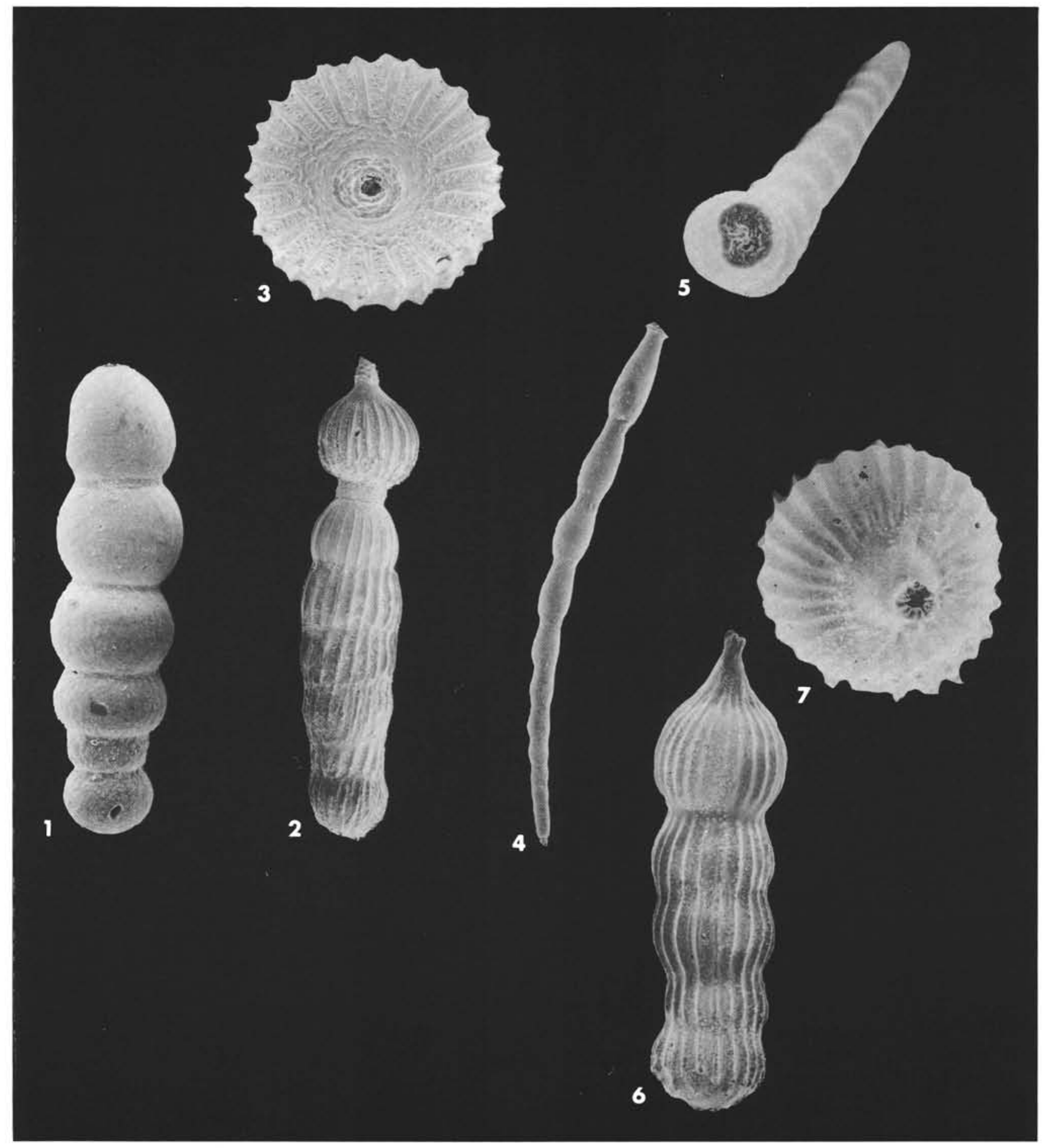

Plate 13. 1. Orthomorphina koina Schwager, Sample 591-7,CC, $\times 95$. 2-3. Nodosaria scalaris Schwager, Sample $591-16, \mathrm{CC},(2) \times 29$; $(3) \times 85$. 4-5. Stilostomella consobrina (d'Orbigny), Sample 591-17,CC, (4) $\times 40 ;(5) \times 152$. 6-7. Nodosaria costornata Schwager, sample 591-22,CC, $(6, \times 45 ; 7, \times 120)$. 


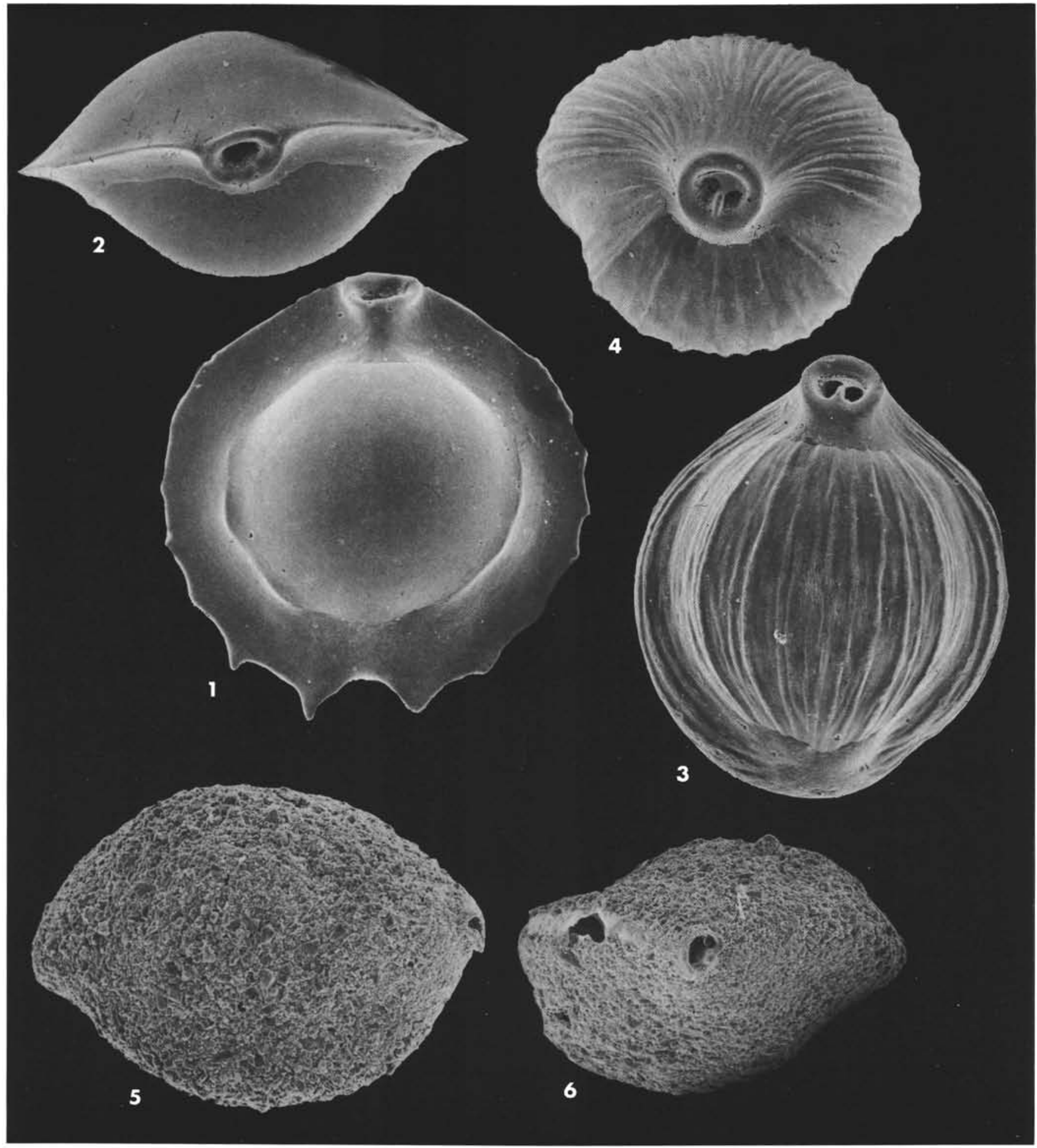

Plate 14. 1-2. Pyrgo serrata (d’Orbigny), Sample 593-1,CC, $(1, \times 180 ; 2, \times 200)$. 3-4. Pyrgo comata (Schwager), Sample 593-1,CC, (3) $\times 143$; (4) $\times 144$. 5-6. Sigmoilopsis schlumbergeri (Silvestri), Sample 590-1,CC, $\times 120$. 


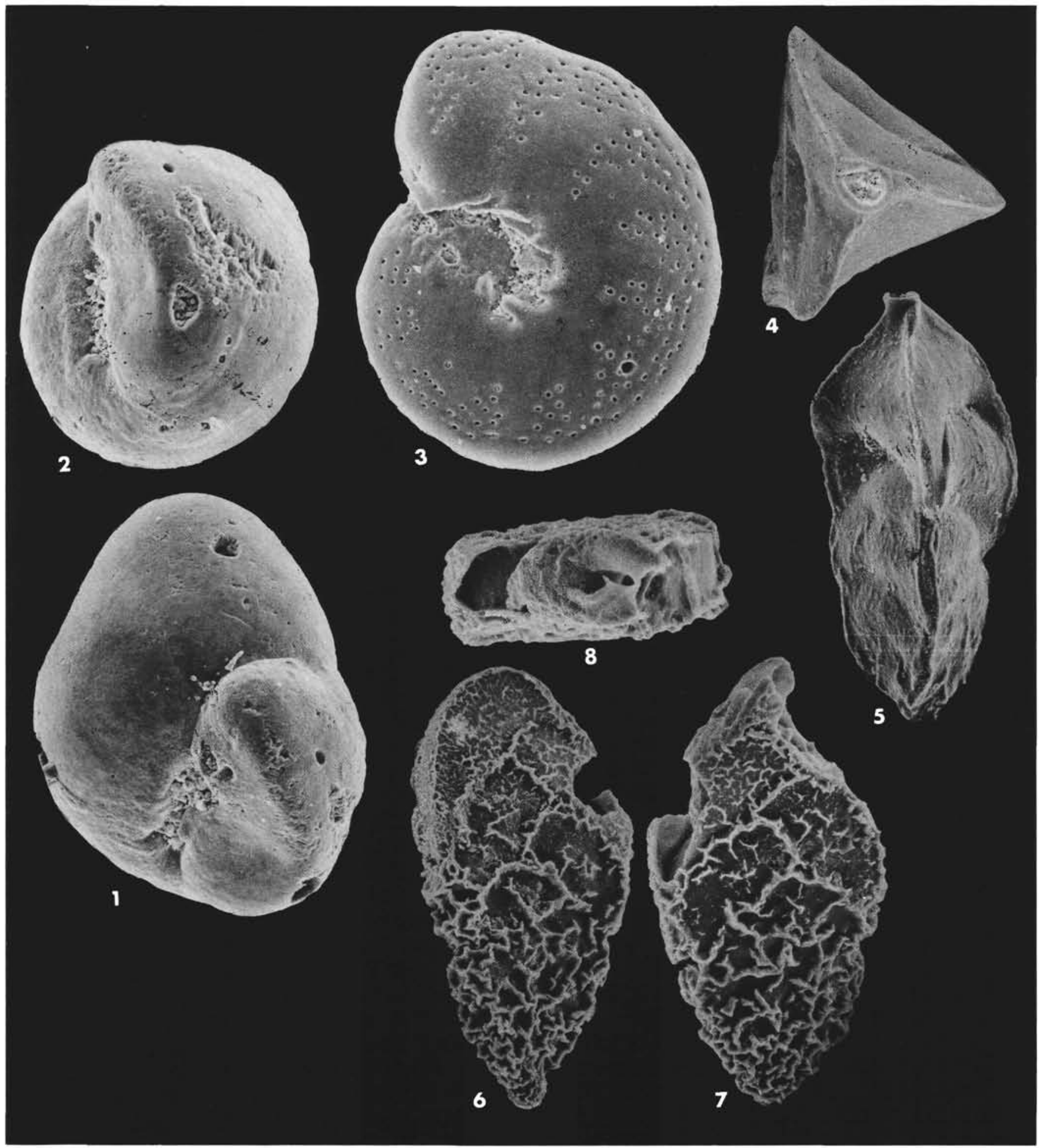

Plate 15. 1-2. Rotaliatina sulcigera Finlay, Sample 592-36-3, $92 \mathrm{~cm},(1) \times 260$; $(2) \times 290$. 3. Anomalinoides orbiculus (Silvestri), Sample 592-36-3, $92 \mathrm{~cm}, \times 200$. 4-5. Trifarina costornata (Hornibrook), Sample 590A-16,CC, (4) $\times 270$; (5) $\times 400$. 6-8. Bolivinita sp., Sample 594-9-3, $90 \mathrm{~cm}$, $(6-7) \times 350 ;(8) \times 410$. 


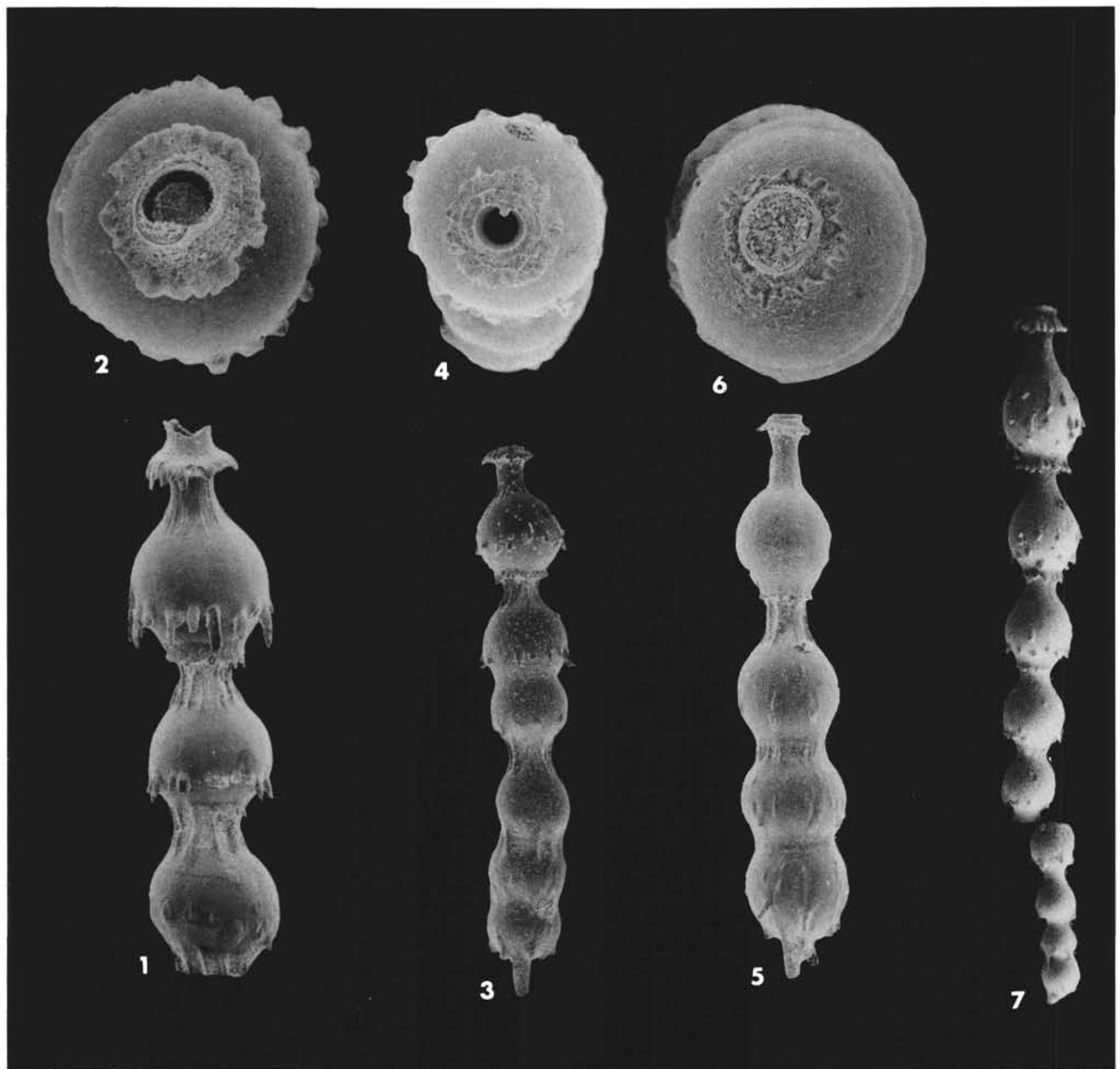

Plate 16. 1-2. Stilostomella lepidula Schwager, Sample 591-24,CC, $(1) \times 54 ;(2) \times 115$. 3-4. Stilostomella lepidula trans. Siphonodosaria insecta (Schwager), Sample 591-29,CC, (3) $\times 49 ;$ (4) $\times 115$. 5-6. Siphonodosaria insecta (Schwager), Sample 591-24,CC, (5) $\times 69 ;(6) \times 175$. 7. Stilostomella basicarinata Hornibrook, Sample 529-19,CC, $\times 100$. 


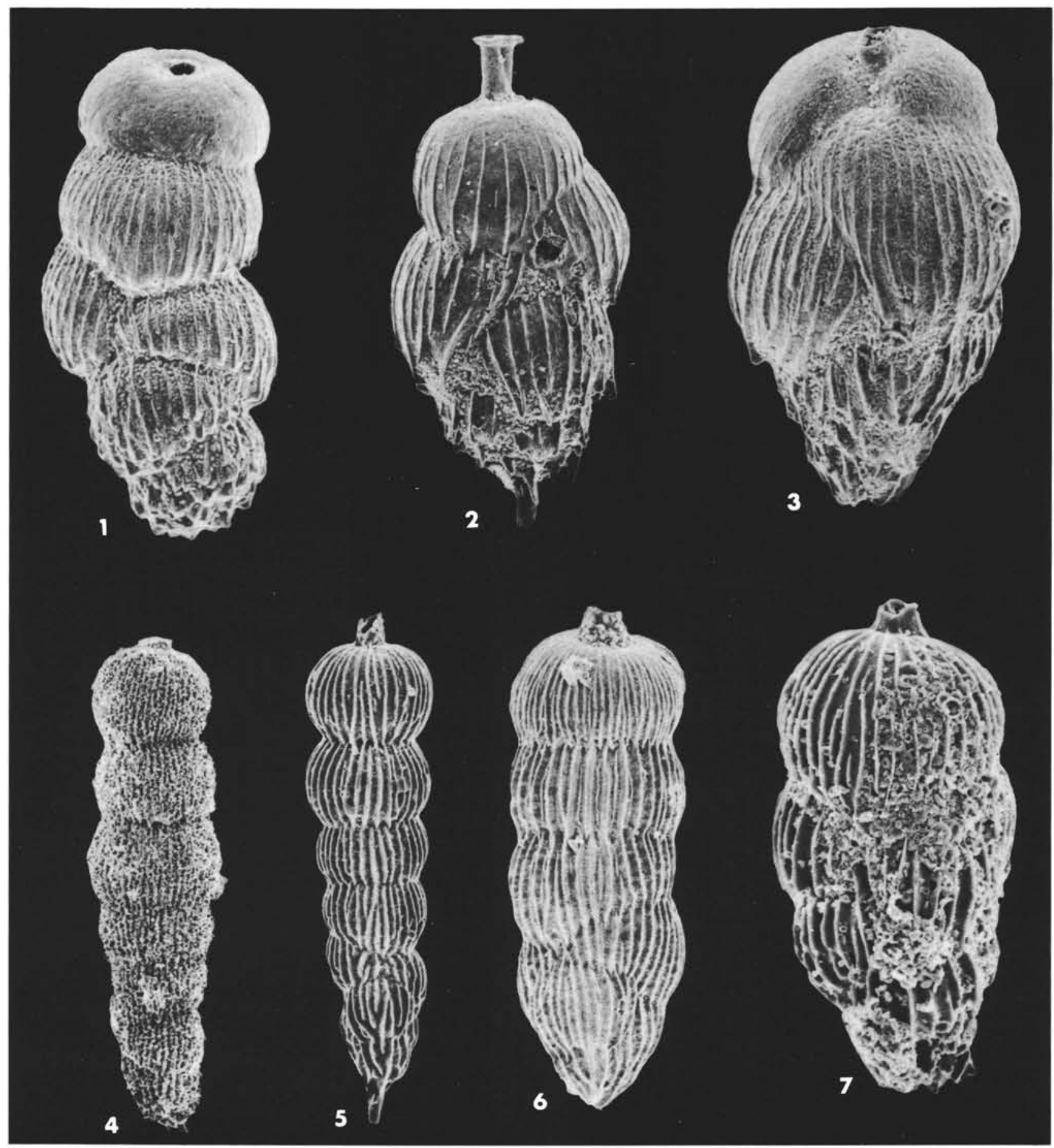

Plate 17. 1, 7. Rectuvigerina prisca Finlay, Sample 592-36-3, $92 \mathrm{~cm},(1) \times 136$; $(7) \times 270$. 2. Rectuvigerina ongleyi Finlay, Sample 592-24,CC, $\times$ 127. 3. Uvigerina spinulosa Hadley, Sample $590 \mathrm{~B}-21, \mathrm{CC}, \times 150$. 4. Rectuvigerina tasmana $\mathrm{n}$. sp., Sample $587-11, \mathrm{CC}, \times 108$. 5. Rectuvigerina striata Schwager, Car Nicobar, CM 1, ×132. 6. Rectuvigerina postprandia Finlay, Site 593-24,CC, $\times 163$. 

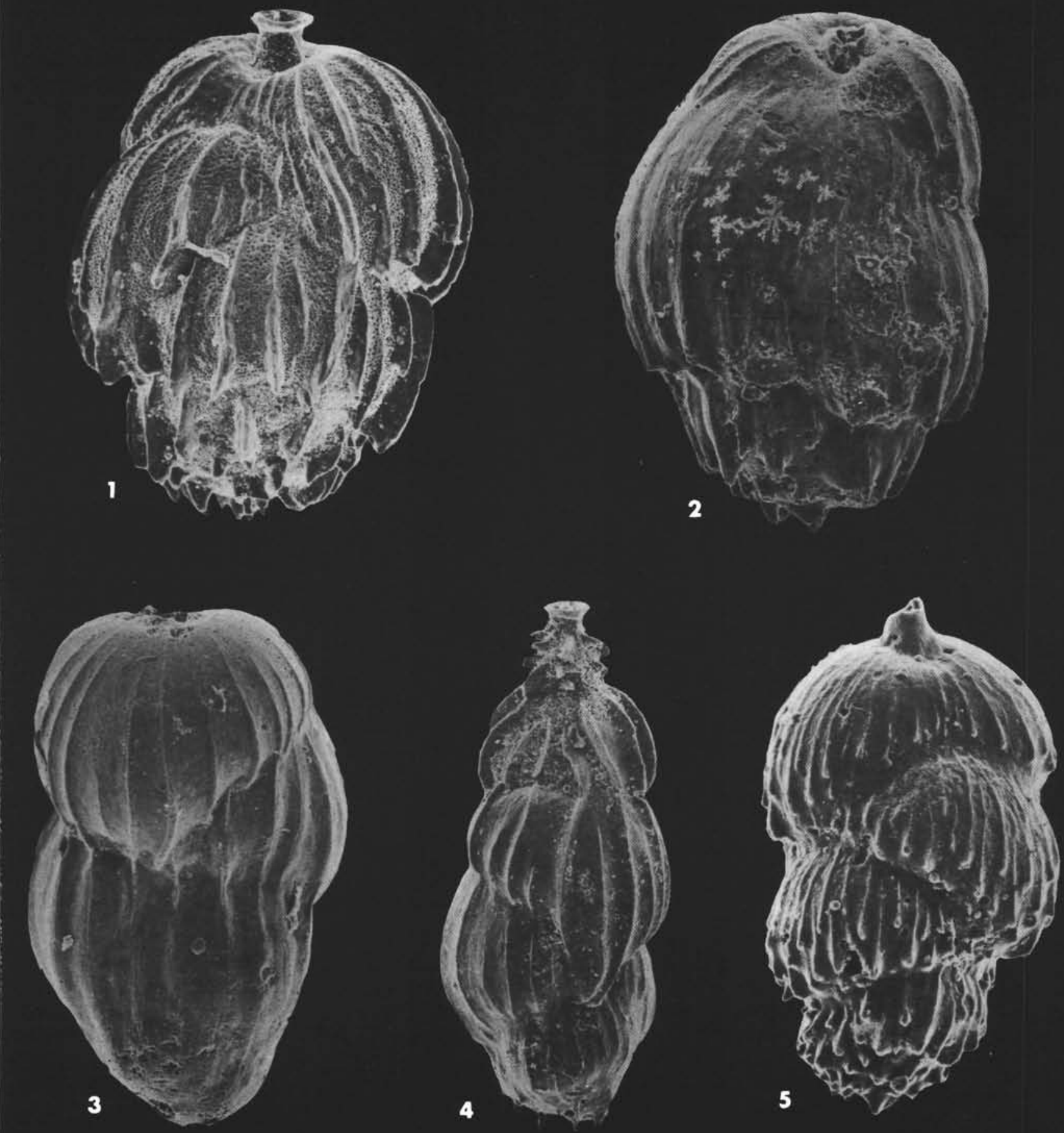

Plate 18. 1. Uvigerina hornibrooki Boersma, Sample 590A-12,CC $\times 167$. 2. Uvigerina eocaena Guembel $\times$ Uvigerina mexicana Nuttall, Sample 93-58-2, $19 \mathrm{~cm}, \times 175$. 3. Uvigerina picki Finlay, Sample 590A-12,CC, $\times 140$. 4. Uvigerina tasmana Boersma, Sample 588-6,CC, $\times 144$ 5. Rectuvigerina spinea (Bermudez), Sample 590B-37,CC, $\times 180$. 


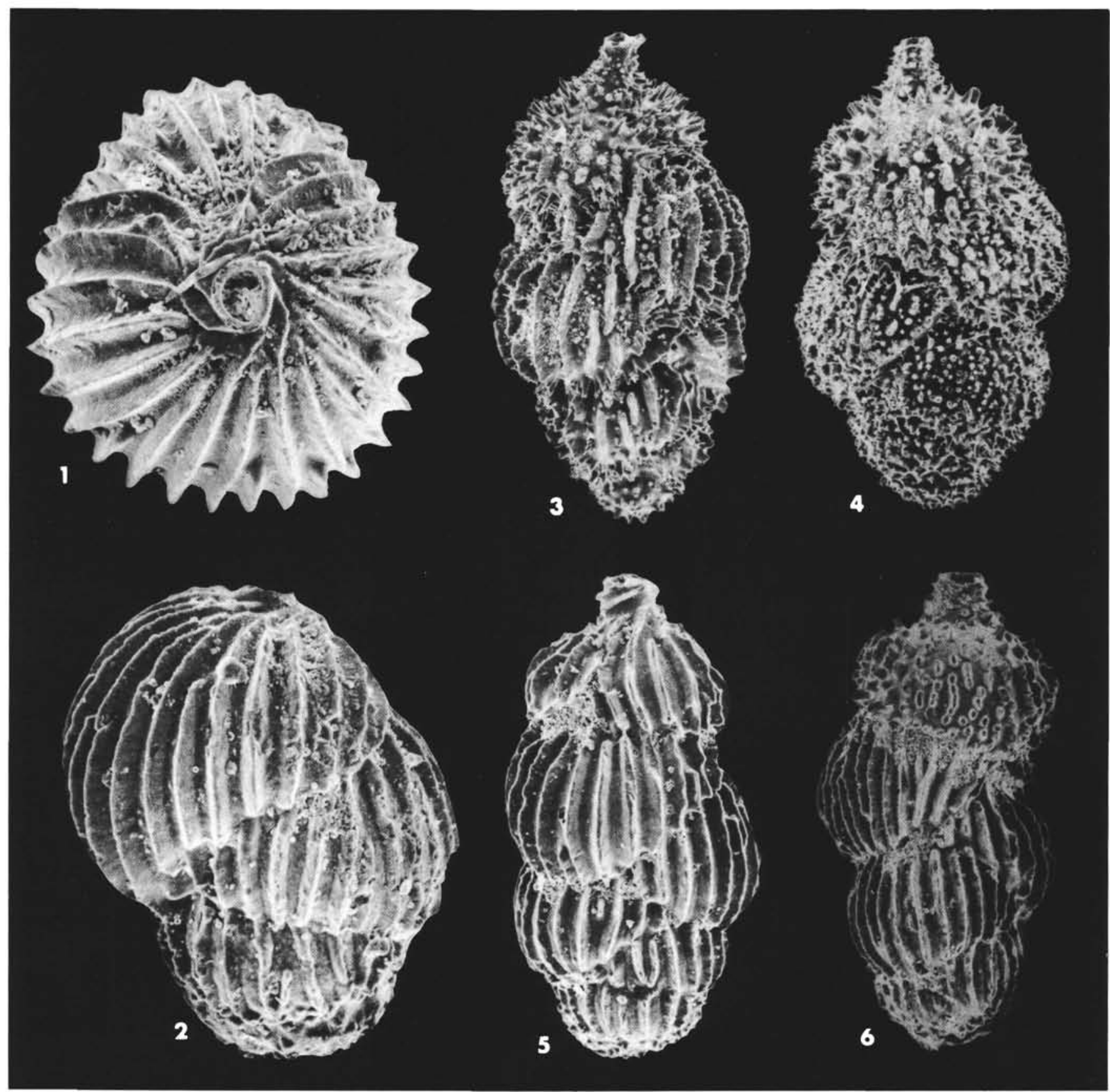

Plate 19. 1-2. Uvigerina rippensis Cole, Sample 592-41,CC, (1) $\times 240$; (2) $\times 260$. 3-4. Uvigerina dirupta Cushman and Todd, (3) Sample 593$1, C C, \times 116$; (4) Sample $588-6, C C, \times 142$. 5. Uvigerina costata Finlay, Sample $592-41, C C, \times 140$. 6. Uvigerina bortotara Finlay, Sample 592-41, CC, $\times 150$. 

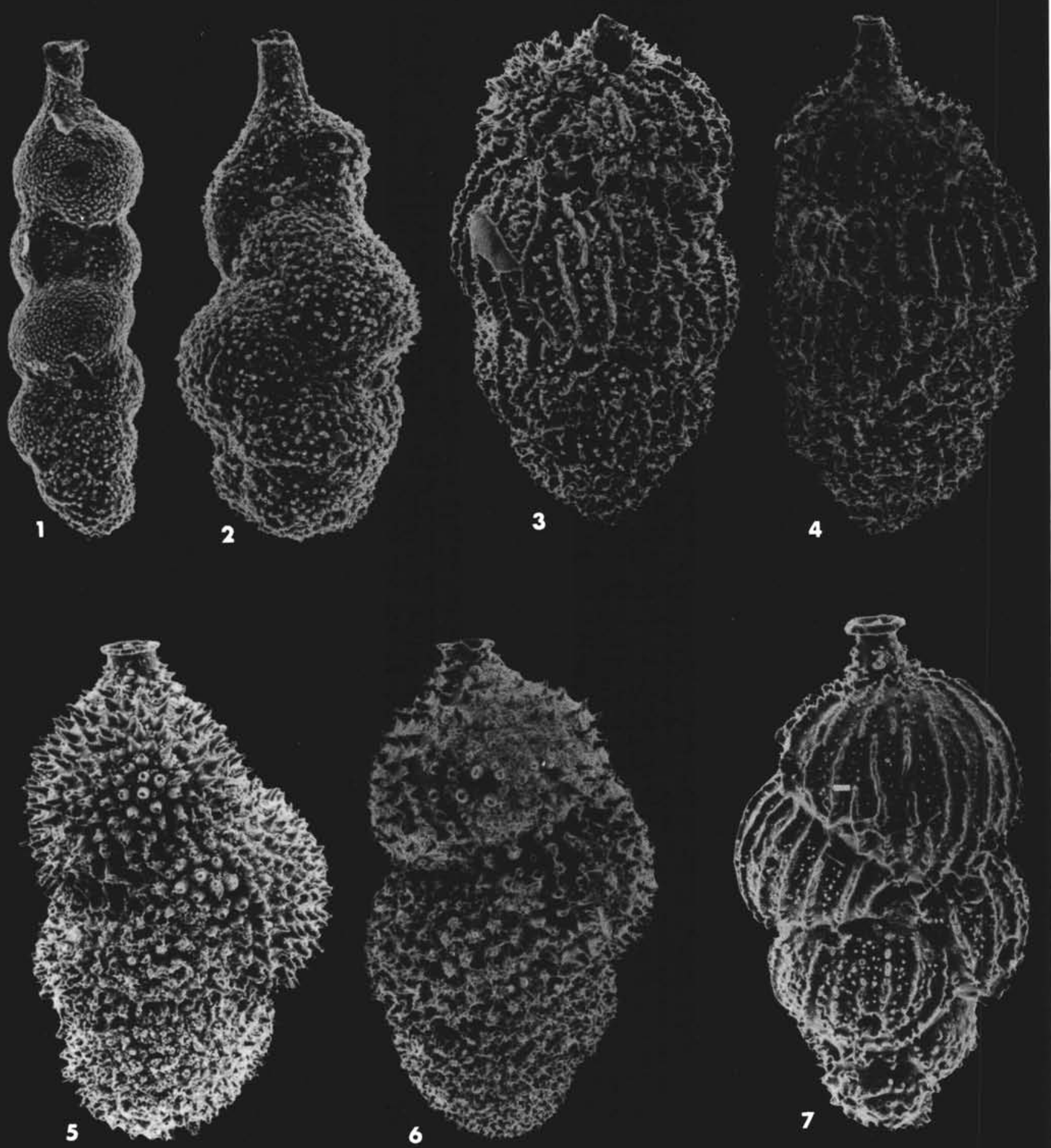

Plate 20. 1. Uvigerina auberiana d'Orbigny, Sample 586B-6,CC, $\times 155,2$. Uvigerina proboscidea Schwager, Sample 588C-24,CC, $\times 270$. 3-4. Uvigerina hispido-costata Cushman and Todd, (3) Sample 592-6,CC, $\times 172$; (4) Sample 590A-5,CC, $\times 131$. 5-6. Uvigerina hispida Schwager, (5) Sample 590A-16,CC, $\times 116$; (6) Sample 591-27,CC, $\times 87$. 7. Uvigerina interrupta-costata Le Roy, Sample 586B-6,CC, $\times 150$. 